
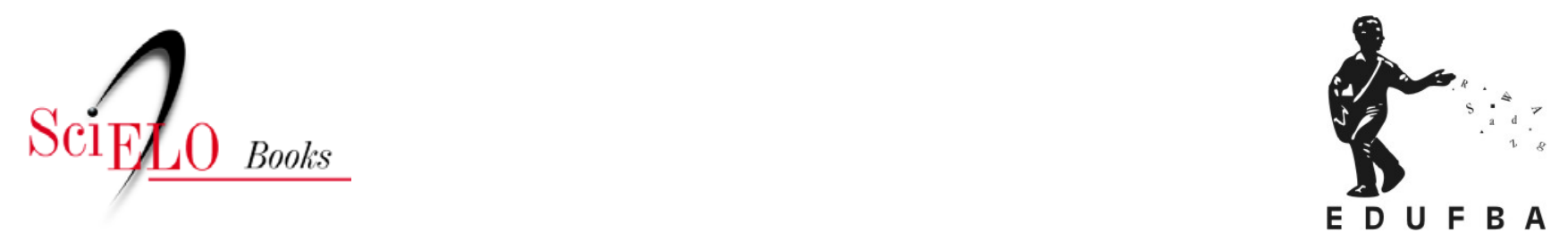

\title{
Prisões numa abordagem interdisciplinar
}

\author{
Maria Thereza Ávila Dantas Coelho \\ Milton Júlio de Carvalho Filho \\ (orgs.)
}

\section{SciELO Books / SciELO Livros / SciELO Libros}

COELHO, M.T.Á.D., and CARVALHO FILHO, M.J., orgs. Prisões numa abordagem interdisciplinar [online]. Salvador: EDUFBA, 2012, 218 p. ISBN 978-85-232-1735-8. Available from: doi: 10.7476/9788523217358. Also available in ePUB from: http://books.scielo.org/id/7mkg8/epub/coelho-9788523217358.epub.

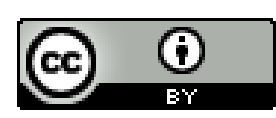

All the contents of this work, except where otherwise noted, is licensed under a Creative Commons Attribution $\underline{4.0 \text { International license. }}$

Todo o conteúdo deste trabalho, exceto quando houver ressalva, é publicado sob a licença Creative Commons Atribição 4.0.

Todo el contenido de esta obra, excepto donde se indique lo contrario, está bajo licencia de la licencia Creative Commons Reconocimento 4.0. 


\section{Prisões numa abordagem interdisciplinar}




\title{
Universidade Federal da Bahia
}

\author{
Reitora \\ Dora Leal Rosa
}

Vice Reitor

Luiz Rogério Bastos Leal

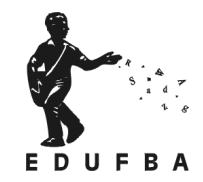

Editora da Universidade

Federal da Bahia

\section{Diretora}

Flávia M. Garcia Rosa

\section{Conselho Editorial}

Alberto Brum Novaes

Angelo Szaniecki Perret Serpa

Caiuby Álves da Costa

Charbel Niño El Hani

Cleise Furtado Mendes

Dante Eustachio Lucchesi Ramacciotti

Evelina de Carvalho Sá Hoisel

José Teixeira Cavalcante Filho

Maria Vidal de Negreiros Camargo 
Maria Thereza Ávila Dantas Coelho

Milton Júlio de Carvalho Filho

(Organizadores)

\section{Prisões numa abordagem interdisciplinar}




\section{2, Autores}

Direitos para esta edição cedidos à Editora da Universidade Federal da Bahia.

Feito o depósito legal.

J. Nascimento

Projeto gráfico e editoração

\section{Simone Mota Sant'Anna}

Capa

Thereza Coelho

Foto

\section{Rodrigo Meirelles}

Normalização

\section{Flávia Goullart Mota Garcia Rosa}

Revisão

\section{Sistema de Bibliotecas - UFBA}

Prisões numa abordagem interdisciplinar / Maria Thereza Ávila Dantas Coelho, Milton Julio de Carvalho Filho (Org.). - Salvador : EDUFBA, 2012.

$218 \mathrm{p}$.

ISBN 978-85-232-0948-3

1. Prisão - Brasil. 2. Prisão - Brasil - Aspectos sociais. 3. Prisioneiros - Brasil.

4. Prisioneiros - Direitos fundamentais - Brasil. I. Coelho, Maria Thereza Ávila Dantas.

II. Carvalho Filho, Milton Julio de

Editora filiada à

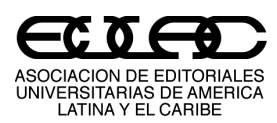
LATINA Y EL CARIBE
L

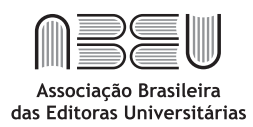

das Editoras Universitárias

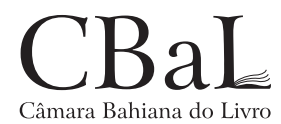

Câmara Bahiana do Livro

EDUFBA

Rua Barão de Jeremoabo, s/n, Campus de Ondina, 40170-115 Salvador-BA Brasil

Tel/fax: (71)3283-6160/3283-6164

www.edufba.ufba.br | edufba@ufba.br 


\section{Sumário}

O anacronismo penitenciário 7

Maria Fernanda Tourinho Peres

Introdução 11

Maria Thereza Ávila Dantas Coelho

Milton Júlio de Carvalho Filho

A implantação do trabalho prisional na penitenciária da Bahia (1833-1865) 15

Cláudia Moraes Trindade

Prisões e globalização $\mathbf{3 1}$

António Pedro Dores

Terceirização de prisões: notas de uma análise comparada $\mathbf{5 3}$

Sandro Cabral

Paulo Furquim de Azevedo

A análise da rede de vínculos de autores de delitos como uma contribuição para a compreensão do comportamento delituoso: um estudo de caso $\mathbf{7 5}$ Odilza Lines de Almeida

Na frente das grades: uma pesquisa com agentes penitenciários da região metropolitana de Belo Horizonte $\mathbf{9 7}$

Luiz Claudio Lourenço 
Saúde mental entre presidiários na cidade do Salvador, Bahia, Brasil 121

Antônio Carlos Cruz Freire

Milena Pereira Pondé

Milena Siqueira Santos Mendonça

A saúde mental de infratores presos numa unidade prisional da cidade do Salvador $\mathbf{1 3 1}$

Maria Thereza Ávila Dantas Coelho

Pedófilos e agressores sexuais de crianças e adolescentes: narrativas a partir do cárcere $\mathbf{1 4 5}$ José Gonçalo Estrela Zúquete

Ceci Vilar Noronha

A criança e o sistema prisional $\mathbf{1 6 1}$

Cláudia Regina Vaz Torres

Sujeitos da fronteira. A saída da prisão $\mathbf{1 7 9}$

Milton Júlio de Carvalho Filho

Deixa eu ver sua alma - Narrativa de si como política de si em escritos de Luiz Alberto Mendes 197

Denise Carrascosa

Sobre os autores $\mathbf{2 1 5}$ 


\section{O anacronismo penitenciário}

Nas últimas décadas do século XX consolida-se em grande parte dos países ocidentais uma política de encarceramento em massa. (SALLA, 2001) No Brasil, exemplos máximos dessa tendência encontram-se nos Estados de São Paulo e Minas Gerais. Em São Paulo, por exemplo, a taxa de aprisionamento passou de 276,5 por $100 \mathrm{mil}$ habitantes com mais de 18 anos, em 1996, para 524,6 em 2008, um crescimento de cerca de 90\%. (PERES et al., 2011) No Brasil, a população prisional passou de 361.402 presos em 2005 para 473.636 em 2009, segundo dados oficiais do Sistema Integrado de Informações Penitenciárias do Ministério da Justiça (INFOPEN/MJ). (BRASIL, 2012) O crescimento da população carcerária é destacado no $4^{\circ}$ Relatório Nacional sobre Direitos Humanos no Brasil, publicado em 2010 pelo Núcleo de Estudos da Violência da Universidade de São Paulo. Esse crescimento ocorreu em todas as regiões do país e na quase totalidade dos estados, sendo mais acentuado na Bahia (94,8\%) e em São Paulo (63,6\%). (NEV/USP, 2010) Cabe ressaltar que o aumento no número de presos não foi acompanhado por um aumento da mesma ordem no número de vagas no sistema, embora tenham sido criadas novas vagas e novos estabelecimentos penitenciários. Entre 2005 e 2009 o número de vagas passou de 206.559 para 294.684, e o número de estabelecimentos penitenciários cresceu de 1.020 em 2006 para 1.134 em 2008, ainda segundo os dados oficiais do INFOPEN/MJ. Permanece, entretanto, o grave e crônico problema da superlotação: a relação entre o número de presos e o número de vagas no sistema penitenciário se mantém na ordem de 1,4 presos para cada vaga disponível, considerando o período entre 2005 e 2009. (BRASIL, 2012)

Os dados acima põem em evidência a atualidade da temática desta coletânea. O livro Prisões numa abordagem interdisciplinar nos brinda com distintos olhares sobre um dos nós mais difíceis de serem 
desatados no percurso que temos trilhado para a constituição de uma sociedade democrática e de respeito aos Direitos Humanos: a questão penitenciária. Nesse sentido, é importante ressaltar que a política de encarceramento em massa, o crescimento da população carcerária e a construção de novas instituições prisionais - algumas de segurança máxima, seguindo a tendência da política de encarceramento norte-americana - não decorrem da constatação de que a política prisional e a instituição prisão vêm tendo, ao longo dos anos, bons e promissores resultados no que se refere à sua "vocação" para a "recuperação" de criminosos. São múltiplos e patentes os sinais de que o sistema é falho e que o modelo do aprisionamento como forma privilegiada de punição está longe de ser o ideal. O aumento da criminalidade, seja em termos quantitativos, seja pelo surgimento de novas modalidades criminais (SALLA, 2001), atesta que o esperado efeito dissuasório não ocorre como esperado. As múltiplas e gritantes "crises" do sistema penitenciário, com rebeliões, fugas, denúncia de tortura de presos e múltiplas formas de violação de direitos somam-se à infiltração do crime organizado em seu interior e à corrupção dos agentes que, a princípio, seriam responsáveis pela manutenção da lei e da ordem.

Dessa forma, mostra-se em certo sentido anacrônico esse avanço do sistema punitivo prisional: investe-se num modelo falido ao mesmo tempo em que se aposta, no nível discursivo, em modelos alternativos - estes ainda longe do centro da política penal nacional. Esse anacronismo, entretanto, não deve nos causar surpresas. A prisão é uma instituição que nasce pautada nessa condição. Basta lembrar que, junto com o surgimento da prisão como instituição central para a política punitiva, brilhantemente trabalhado por Foucault (1987), surgem as propostas de sua reforma. A prisão já nasce fadada a falir, mas, apesar disto, mantém-se e expande-se no mundo contemporâneo. Para Salla (2001), um dos maiores especialistas em estudos sobre o sistema penitenciário no Brasil, esta sobrevida da prisão, apesar da falência do modelo prisional em sua proposta de "recuperação" do criminoso, só pode ser compreendida se levarmos em conta a sua função nas sociedades modernas, seguindo as pistas deixadas por Foucault em Vigiar e Punir.

Tomar a prisão e a população prisional como objeto de estudo e reflexão é ainda um desafio. São escassos os dados disponíveis e difíceis 
os caminhos da pesquisa no sistema penitenciário. Dessa forma, os trabalhos apresentados neste livro vêm preencher uma lacuna importante, especialmente por sua abordagem interdisciplinar. Os estudos e pesquisas que se originam em diversos campos do conhecimento, apresentados nesta coletânea, compõem um quadro rico que explora dimensões distintas de um grave e crônico problema nacional. Esperamos que seja um estímulo ao desenvolvimento de novas pesquisas e à publicação de cada vez mais estudos sobre a questão penitenciária. Parabéns aos organizadores e aos autores!

São Paulo, 27 de janeiro de 2012.

Maria Fernanda Tourinho Peres Departamento de Medicina Preventiva Faculdade de Medicina-USP

Núcleo de Estudos da Violência-USP

\section{Referências}

BRASIL. Ministério da Justiça. Sistema Integrado de Informações

penitenciárias do Ministério da Justiça (INFOPEN/MJ).

Dados disponíveis em: <http://portal.mj.gov.br/data/Pages/

MJD574E9CEITEMIDC37B2AE94C6840068B1624D28407509CPTBRNN.

htm>. Acesso em: 27 jan. $2012>$.

FOUCAULT, M. Vigiar e Punir. Nascimento da prisão. 9. Ed. Tradução

Ligia M. Pondé Vassallo. Petrópolis: Vozes, 1987.

NEV/USP - NÚCLEO DE ESTUDOS DA VIOLÊNCIA DA UNIVERSIDADE

DE SÃO PAULO. $4^{\circ}$ Relatório Nacional sobre os Direitos Humanos no

Brasil- NEV/USP, 2010. Disponível em: < http://www.nevusp.org > Acesso em: 26 jan. 2012.

PERES, Maria Fernanda Tourinho et al. Queda dos homicídios no Município de São Paulo: uma análise exploratória de possíveis condicionantes. Revista Brasileira de Epidemiologia, v. 14, n. 4, p. 709-21, 2011.

SALLA, F. A retomada do encarceramento, as masmorras High Tech e a atualidade do pensamento de Michel Foucault. Cadernos

da F.F.C, Marília: UNESP, v. 9, n. 1, p. 35-58, 2001. Disponível em:< http://www.nevusp.org/portugues/index.php?option =com_ content\&task $=$ view\&id $=1016 \&$ Itemid $=118>$. Acesso em: 26 jan. 2012. 


\section{Introdução}

Maria Thereza Ávila Dantas Coelho

Milton Júlio de Carvalho Filho

Visando colaborar com a discussão de temas relativos ao sistema prisional brasileiro numa perspectiva interdisciplinar, este livro traz o resultado de uma série de pesquisas e reflexões de pesquisadores que, ao longo de alguns anos, vêm se dedicando ao estudo das prisões. Destina-se tanto aos estudiosos, quanto aos estudantes interessados no tema, além dos gestores e trabalhadores que, no seu cotidiano, lidam com algumas das questões abordadas aqui.

A particularidade dessa obra é sua articulação interdisciplinar. Desde uma abordagem histórica sobre prisões, passando por reflexões oriundas das áreas da Medicina, da Psicologia, da Administração, da Sociologia e da Antropologia, até a abordagem dos Estudos Literários. Isso comprova que essas áreas há muito venceram as barreiras das suas especificidades e podem dialogar para tratar de objetos complexos como são as prisões.

Num primeiro momento, o livro trata de aspectos históricos, sociais e econômicos que conformam o atual contexto do sistema prisional brasileiro. Faz uma retrospectiva histórica da implantação do trabalho no sistema prisional baiano, a partir das discussões sobre a reforma prisional no Brasil e no mundo, iniciadas no século XIX. Situa as prisões como um fenômeno global, atrelado à ideia de sistema penal, que reproduz segredos sociais sobre maus-tratos e injustiças institucionais. Problematiza o crescimento global do número de prisioneiros, assim como a participação privada na gestão e na operacionalização das prisões, através das privatizações, das concessões, das terceirizações e das parcerias público-privadas. Os textos de Claudia Trindade, Antonio Pedro Dores, Sandro Cabral e Paulo Azevedo seguem nessa direção. 
Num segundo momento, o livro apresenta e reflete sobre os resultados de algumas pesquisas realizadas no sistema prisional baiano. O texto de Odilza Almeida analisa a rede de vínculos de um autor de delito e suas relações com o comportamento criminoso. O texto de Luiz Cláudio Lourenço discute o perfil dos agentes penitenciários, suas "dores" e profissionalização. Os textos de Antônio Carlos Cruz Freire, Milena Pereira Ponde, Milena Siqueira Santos Mendonça e Maria Thereza Ávila Dantas Coelho avaliam a saúde mental de presos, sugerindo que uma melhor atenção aos detentos portadores de transtorno mental pode, talvez, reduzir as taxas de criminalidade. O texto de José Gonçalo Estrela Zúquete e Ceci Vilar Noronha nos traz o perfil e as narrativas de alguns pedófilos e agressores sexuais de crianças e adolescentes, a respeito de seus crimes e vivência carcerária. O texto de Cláudia Regina Vaz Torres problematiza a construção da infância e da identidade pessoal no entorno das prisões, quando as crianças são cumpridoras solidárias do encarceramento de suas mães.

Num terceiro momento, após a discussão do sistema prisional, o livro permite entender os seus resultados a partir de pesquisas sobre as experiências de vida de ex-detentos, que refletem sobre o retorno à liberdade. Esses trabalhos foram realizados sob a perspectiva de que tais experiências são reestruturadoras da identidade dos sujeitos e deixam marcas capazes de influenciar nas suas vidas e nas suas possibilidades emancipatórias. Eles exemplificam os resultados da experiência prisional pelas tentativas de retorno à vida social fora da prisão e através do processo de escrita acerca da própria vida, por parte de um egresso desse sistema. Os textos de Milton Julio de Carvalho Filho e Denise Carrascosa são tributários desses processos.

A prisão é uma instituição complexa e produtora de diversos saberes. Assim, não podemos totalizá-la por nenhuma das suas singularidades. Devemos atentar para a conjunção de pluralidades analíticas que a compõe. Qualquer discussão sobre o sistema prisional implica em determinarmos quem fala, do que ou de quem fala, de quando fala e de onde fala. A ideia desse livro nasceu como resultado do primeiro Seminário de Estudos Prisionais, realizado em 2009, na Universidade Federal da Bahia. Esse Seminário possibilitou o reconhecimento e a aproximação entre pesquisadores que refletem e discutem o sistema prisional a partir de diversas áreas do conhecimento e com questões 
complexas e variadas. Não consideramos necessário formatar o livro numa única abordagem, mas misturá-las, visando provocar no leitor a percepção de quão complexa é a questão e do quanto ainda devemos dialogar a esse respeito para uma efetiva compreensão da sua totalidade.

Além das abordagens sobre as prisões do Estado da Bahia, as paulistas e as mineiras também são contempladas no livro, além da experiência portuguesa. Toda essa junção de análises sobre as prisões foi elaborada pelos organizadores desta obra, pesquisadores do Núcleo de Estudos Interdisciplinares em Saúde, Violência e Subjetividade (SAVIS), da Universidade Federal da Bahia. 


\section{A implantação do trabalho prisional na penitenciária da Bahia (1833-1865) ${ }^{1^{*}}$}

Cláudia Moraes Trindade

\section{Introdução}

A partir da segunda metade do século XIX foram inauguradas as penitenciárias no Brasil, também denominadas de Casa de Correção e Casa de Prisão com Trabalho. Naquela época pouco se produzia intelectualmente sem a influência das ideias estrangeiras, as quais sofriam adaptações para a realidade local. ${ }^{2}$ Assim aconteceu com a implantação do projeto civilizatório que tomou conta do Brasil no oitocentos. Instituições foram construídas no intuito de acompanhar os padrões de controle social em voga nos países como a França, Inglaterra e Estados Unidos. No decorrer do século XIX, cemitérios, asilos, hospitais, colégios, internatos e prisões foram gradativamente fazendo parte do cenário da capital baiana ao mesmo tempo em que seus regulamentos se adaptavam a uma sociedade escravista específica como

1 * Este texto é parte de uma pesquisa mais ampla desenvolvida durante o mestrado no Programa de Pós-Graduação em História da UFBA, sob a orientação do Prof. João José Reis, a quem agradeço pelas sugestões e indicação de fontes e bibliografia. A pesquisa contou com o apoio do CNPq. O assunto tratado aqui foi apresentado, em 2008, no V Colóquio Internacional de Trabalho Forçado Africano - Brasil, 120 anos da Abolição. Agradeço aos membros da linha de pesquisa Escravidão e Invenção da Liberdade, do PPGH/UFBA, pelos comentários feitos a uma versão anterior.

2 Sobre o liberalismo, ver Marson (2002), Mattos (1990), Silva (1997, entre outros. 
era a nossa naquele período. ${ }^{3}$ Conforme sinalizou Michel Foucault, essas instituições de vigilância exerciam um poder social que visava enquadrar as pessoas no mundo capitalista. Para o autor, a atuação desse poder social esperava que "o homem transformasse seu corpo, sua existência e seu tempo em força de trabalho”. (FOUCAULT, 2003, p. 67) Essas instituições atuavam como uma ameaça para as pessoas que não atendiam aos padrões civilizatórios defendidos pelas elites locais. Para as classes mais abastadas as ruas e praças da cidade ocupadas por mendigos, escravos, pessoas doentes, abandonadas à própria sorte, era um dos empecilhos para que a Bahia alcançasse o seu espaço no mundo civilizado. A população baiana, em sua maioria, vivia na mais absoluta pobreza. Segundo Mattoso (1974), os pobres representavam cerca de 90\% dos habitantes de Salvador no século XIX. Sem contar a população escrava que era bastante significante. Em 1835, por exemplo, dos 65.500 habitantes, 42\% eram escravos. (REIS, 2003) Entretanto, a tentativa de controlar essa população foi uma tarefa árdua para as autoridades da época.

16 No início da década de 1830, as discussões sobre a reforma prisional tomaram força na Bahia e no Brasil de um modo geral. Porém, os primeiros passos desse projeto foram dados antes mesmo da independência do Brasil. Pouco tempo depois de assumir a regência, D. Pedro I assinou a Lei de 23 de maio de 1821 que visava garantir os direitos individuais contra a arbitrariedade dos juízes criminais no Brasil. Dentre outras medidas, essa lei proibia que os presos fossem conservados nas masmorras "escuras ou infectas", e sim em cadeias "arejadas e cômodas" sendo que eles não deviam sofrer "qualquer espécie de tormento”. (COELHO, 1999) Essa determinação antecedeu o que a Constituição viria reforçar em 1824. Outro acontecimento importante naquele momento foi a atuação de Cipriano Barata na Corte de Lisboa, em fevereiro de 1823, onde, entre outros projetos, apresentou um que reivindicava mudanças no aparelho prisional do Brasil. Ele que conheceu de perto as masmorras das fortalezas e as cadeias coloniais, devido às várias vezes em que foi preso, em seu pronunciamento, remeteu-se diretamente à Bahia, pedindo que fossem interditadas as prisões do forte de São Pedro e as do forte do Mar. (TRINDADE, 2007) A sua

3 Sobre essas instituições baianas oitocentistas, ver Reis (1991), Fraga Filho (1999), Rios (2006), Matta (1996), Leal (1996), Trindade (2008), Kraay (2001). 
reivindicação não foi atendida. Em 1832, Cipriano constatou de perto que a prisão da fortaleza do mar funcionava em pleno vigor. Ele era um dos presos políticos que ali estavam. (TRINDADE, 2007) Em 1824, a Constituição do Brasil determinou a construção de cadeias arejadas, limpas e com várias celas, prezando também pela separação de presos conforme a natureza de seus crimes. Proibiu as torturas e estipulou a elaboração de um Código Criminal para substituir o temido livro V das Ordenações Filipinas, que até então regia as leis criminais no Brasil.

Em 1833, a Bahia iniciou a construção da sua primeira penitenciária que foi inaugurada no ano de 1861. A instituição recebeu o nome de Casa de Prisão com Trabalho e representou para a província um importante passo no projeto da reforma prisional baiana. ${ }^{4}$ (SALLA, 1997) A instituição foi construída na periferia da cidade de Salvador, nas terras fronteiras ao Engenho da Conceição aos fundos da Capela dos Mares, na Freguesia da Nossa Senhora da Penha de França de Itapagipe. A partir de 1870, esta freguesia foi desmembrada e o local passou a pertencer à Freguesia de Nossa Senhora dos Mares. ${ }^{5}$ Foi nesta penitenciária que as autoridades baianas planejaram colocar em prática um novo conceito de punição, baseado na privação da liberdade e na reabilitação do condenado. Na época, o Brasil acompanhava uma tendência mundial de modernização das prisões, que teve início na Inglaterra e nos Estados Unidos no final do século XVIII. As execuções e as torturas em praças públicas, utilizadas para atemorizar a quem estivesse planejando novos crimes foram, gradativamente, abandonadas pelos países do Ocidente. Entrava em cena a penalidade moderna, que privava o criminoso do seu bem maior - a sua liberdade - internando-o numa instituição construída, especificamente, para recuperá-lo, que recebeu o nome de penitenciária. O funcionamento desta instituição era regido por normas que seriam aplicadas de acordo com o sistema penitenciário adotado. Esses sistemas utilizavam como método de punição e recuperação elementos como o trabalho, a religião, a disciplina, o uso de uniformes, o silêncio e, sobretudo, o isolamento.

4 O termo "casa" era usado anteriormente para designar as cadeias, como, por exemplo, Casa de Câmara e Cadeia. Em relação ao nome "casa penitenciária", Fernando Salla (1997) sugere que a palavra "Casa" deva ser entendida como era utilizada no período colonial, "especialmente para se referir a uma casa de prisão, ou seja, uma dependência, uma sala, um cômodo, no interior de uma construção".

5 Atualmente esta área é conhecida como Baixa do Fiscal e no edifício da antiga Casa de Prisão funciona o Hospital de Tratamento e Custódia do Estado da Bahia. 
Dessa forma, esperava-se criar um "novo homem" que seria devolvido à sociedade com todos os atributos necessários à convivência social, principalmente para o trabalho. ${ }^{6}$ (TRINDADE, 2007)

Dois sistemas rivais - Auburn e Pensilvânia - dividiram as opiniões dos reformadores estrangeiros e também da Bahia. O sistema de Auburn, também conhecido como silent system, consistia na prática de atividades coletivas durante o dia, no mais absoluto silêncio, e no isolamento à noite. O outro, chamado de sistema da Pensilvânia, sistema da Filadélfia, ou ainda, de sistema celular, estabelecia o isolamento do preso, dia e noite, executando trabalhos individuais, como o artesanato. Neste último caso, as celas deveriam ser especiais, isto é, mais espaçosas; adaptadas para que o preso passasse ali todo o tempo. Neste caso o custo era bem maior do que no modelo Auburniano. Em ambos os sistemas o trabalho prisional era o pivô do processo de reabilitação.

\section{O trabalho prisional e o trabalho forçado}

O Código Criminal do Império do Brasil de 1830 estabeleceu a pena de prisão com trabalho para a maioria dos crimes, desde que o infrator não fosse de condição escrava. Para este último, o Código reservou o seu artigo 60 que previa punição com açoites e, em alguns casos, galés e pena de morte. ${ }^{7}$ (FILGUEIRAS JUNIOR, 1876) O Código também determinou que a pena de prisão com trabalho deveria ser cumprida em instituições construídas, especificamente, para este fim e, enquanto as províncias não dispusessem de casas de correção, como também eram chamadas as penitenciárias no século XIX, a pena seria comutada para prisão simples. ${ }^{8}$ (FILGUEIRAS JUNIOR, 1876) Significa dizer que o indivíduo condenado à pena de prisão com trabalho não deveria executar qualquer tipo de trabalho, principalmente do lado externo da prisão. Antes da reforma prisional, o trabalho executado pelos presos estava relacionado ao trabalho forçado, como acontecia

6 Sobre a reforma prisional baiana e o processo de implantação da primeira penitenciária da Bahia. (TRINDADE, 2007) Doravante a Casa de Prisão com Trabalho poderá ser indicada pela sigla CPCT ou simplesmente denominada de penitenciária.

7 “Art. 60. Si o réo for escravo, e incorrer em pena que não seja a capital ou de galés, será condenado na de açoutes, e, depois de os soffrer, será entregue a seu senhor, que se obrigará a traze-lo com um ferro, pelo tempo e maneira que o juiz designar". (FILGUEIRAS JUNIOR, 1876)

8 Ver artigos 46 e 49 do Código Criminal do Império. (FILGUEIRAS JUNIOR, 1876) 
com os sentenciados à pena de galés. Neste caso os "galés" eram distribuídos nas obras e serviços públicos da cidade. Vale ressaltar que uma das características do antigo regime prisional era o trânsito de presos pela cidade, desempenhando serviços públicos para garantir o sustento dentro da cadeia. ${ }^{9}$ Este tipo de atividade laboral não fazia parte de nenhum projeto de reabilitação. A pena de galés era aplicada ao sentenciado, independente da sua condição jurídica, muito embora o maior número de condenados a galés fosse formado por escravos. Assim podemos dizer que o trabalho dos presos, no antigo regime prisional, estava relacionado, principalmente, com a figura do escravo, enquanto o trabalho na penitenciária estava direcionado para homens de condição livre e liberta. Carlos Eugênio Soares descreve as várias modalidades de trabalhos forçados e formas de acorrentamento a que os presos, condenados a galés, eram submetidos no Dique da Ilha de Cobras. Uma dessas formas era o libambo - quando três ou mais escravos, unidos por uma corrente, buscavam água para garantir o abastecimento da Ilha. (SOARES, 2003) Ressalto que, mesmo com a implantação das penitenciárias no Brasil, o trabalho forçado dos sentenciados a pena de galés coexistiu com o novo regime prisional enquanto durou a escravidão.

\section{O trabalho prisional em diferentes contextos}

Cada sociedade aderiu ao trabalho prisional de acordo com a sua realidade local. Enquanto o Brasil tinha uma economia escravista, países como a França e os Estados Unidos, por exemplo, viviam um contexto de industrialização. Para Catherine Duprat, referindo-se à reforma prisional na França, a implantação de oficinas de trabalho na prisão tinha lá sua complexidade, pois, entre outras dificuldades, havia o conflito de interesses econômicos com a indústria livre. O Estado contava com o investimento da iniciativa privada, e a figura do empreendedor era outro desafio, uma vez que este visava o lucro do seu investimento. Referindo-se ao empreendedor Duprat observa que "nem pedagogo, nem filantropo, melhorar o prisioneiro não é

9 No século XIX o governo só arcava com a alimentação e vestimentas dos presos pobres, ou seja, aqueles que não contavam com amigos e parentes para auxiliar no seu sustento e também que, por algum motivo, não tivessem condições de trabalhar, seja em serviços internos ou até mesmo fora da cadeia. 
assunto seu”. (DUPRAT, 1819, p. 1997) Michel Foucault informa que por volta de 1840, os operários franceses teriam reagido com greves e protestos contra as oficinas das prisões, devido ao baixo custo da mão de obra penal. Os operários livres acusavam o governo de incentivar o trabalho penal para baixar os salários. (FOUCAULT, 1997; PERROT, 2001; PESSOA, 2000; SALLA, 1994)

Os franceses Alexis de Tocqueville e Gustave de Beaumont estiveram nos Estados Unidos por volta de 1830 a fim de observar as prisões daquele país, buscando melhorias e sugestões para as penitenciárias francesas. Os Estados Unidos eram, na época, a referência mundial dos modelos penitenciários. Embora a dupla de estudiosos franceses preferisse o sistema da Filadélfia por manter o condenado no isolamento contínuo, eles reconheceram que o modelo de Auburn, que previa as oficinas de trabalho, era menos custoso. Tocqueville e Beaumont levantaram importantes considerações sobre o investimento das empresas privadas nas prisões. No relatório, fizeram críticas quanto à organização do trabalho prisional na França ressaltando a interferência desmedida do empreendedor junto aos presos. Por outro lado elogiaram o modelo de organização do trabalho prisional nas prisões norte americanas uma vez que as empresas privadas não tinham nenhum poder de interferência junto aos presos. (SALLA, 1994)

Para David Rothman, que estudou a reforma das prisões nos Estados Unidos, havia semelhanças entre as novas instituições prisionais e as novas fábricas que estavam mudando a economia dos Estados Unidos. "Na aparência e na rotina, a prisão e a fábrica eram parecidas. Ambas enfatizavam a regularidade e a pontualidade. Certamente que a partir dessa observação, alguns historiadores relacionaram as origens das prisões com a nova ordem econômica”. (ROTHMAN, 1995, p. 123) Vimos então que a discussão do trabalho prisional, em países da Europa e nos Estados Unidos, estava atrelada ao processo de industrialização. Na Bahia, o trabalho estava relacionado a uma economia que se encontrava num processo de transição da mão de obra escrava para a livre.

Na Bahia, em 1846, quando as discussões sobre a reforma prisional atingiram o auge, o então presidente da província, Francisco José de Souza Soares de Andréa, nomeou uma comissão composta por bacharéis, médicos e engenheiros para analisar a implantação da Casa 
de Prisão com Trabalho, que se encontrava em construção. ${ }^{10}$ (SYSTEMA PENITENCIÁRIO, 1868) Esse grupo, influenciado por reformadores franceses, entre eles Tocqueville e Beaumont, defendeu que a Bahia não deveria adotar o sistema das oficinas de ofício, ou seja, o chamado sistema de Auburn. Para eles o sistema da Filadélfia ou Pensilvânia, embora mais oneroso, se adaptaria melhor às necessidades locais, pois os presos executariam trabalhos individuais em suas celas. Temia-se que as atividades coletivas poderiam facilitar a corrupção e outros "vícios" entre os criminosos. É bem provável que nossos reformadores estavam a seguir a preferência da França que, nesta época, já havia abandonado o sistema de Auburn e adotado o sistema da Pensilvânia para, mais tarde, em meados da década de 1850 optar pela pena de deportação para a maioria das condenações. (PERROT, 2001) No entanto, a "ilustrada" comissão baiana tinha outras preocupações, dentre elas a de poupar presos políticos do trabalho nas oficinas, o que significa que estava preocupada com as pessoas pertencentes às camadas mais abastadas.

Os nossos presos tinham já profissões a que soltos podem voltar; outros viviam do trabalho do campo que não há utilidade em ensinar-lhes a desprezar; os demais, porque a posição social lhes proíbe as artes mecânicas, ou não tem ofício, ou deles não precisam quando livres: logo para a maior parte nem só lhes não é de utilidade, como até poderia prejudicar-lhes, o mister que dali trouxessem aprendido. (PERROT, 2001, p. 18)

Com esse argumento a comissão sugeriu que a lei fosse revista, a fim de conceder privilégios aos presos políticos, garantindo que "todas as vezes que uma condenação levasse os réus desses crimes a uma penitenciária, o trabalho não lhes fosse obrigatório”. A alegação era que os trabalhos manuais "humilham os instintos literários". (PERROT, 2001, p. 52) A revisão de lei não foi atendida. O temor de que algum de seus pares pudessem terminar numa das oficinas da penitenciária deu ao discurso da comissão um tom que parecia contrário às idéias em voga na época, com relação à instrumentalização para o trabalho

10 A comissão foi composta por pessoas ilustres como Cassemiro de Sena Madureira, Luiz Maria Alves Falcão Moniz Barretto, Eduardo Ferreira França, João Baptista dos Anjos, Francisco Primo de Souza Aguiar, João Baptista Ferrari e João José Barboza de Oliveira. Este último, pai do jurista Rui Barboza, também atuou como Relator do relatório do Systema penitenciário que foi entregue, após um ano de estudos, ao governo provincial. 
da emergente população livre e pobre, discussão esta que antecede a da reforma prisional no Brasil. Conforme Walter Fraga, "ao mesmo tempo em que se anunciava a crise do escravismo pela inevitabilidade do declínio da população escrava, a população livre se multiplicava rapidamente. Logo ficou claro que era desta que dependeria o futuro da produção". (FRAGA FILHO, 1999, p. 170) Muitos políticos acreditavam que o trabalho era um elemento regenerador capaz de afastar os vícios dos criminosos. Em 1842, por exemplo, o presidente da província, Joaquim José Pinheiro de Vasconcellos, escreveu sobre os efeitos do trabalho na população livre:

O tempo empregado no trabalho faltaria para o crime, e mesmo para o vício; e as horas destinadas para o descanso seriam empregadas em calcular as maiores vantagens, que se pudesse tirar do fruto do trabalho, por conseqüência teríamos todo o tempo empregado utilmente. É necessário convencer aos homens pobres, que somente o trabalho os pode fazer menos dependentes dos ricos, e dar-lhes em sentimento mais elevado de sua dignidade de homens livres. (VASCONCELLOS, 1842, p. 5)

No que se refere ao trabalho prisional, a Inglaterra, os Estados Unidos e a França incorporaram experiências das workhouses inglesas desde o século XVI, onde os pobres eram recolhidos a fim de serem disciplinados para o trabalho. No caso brasileiro, as elites incorporaram o trabalho prisional às discussões em voga, desde o início do século XIX, que visavam instrumentalizar a população pobre para o trabalho. (MCGOWEN, 1995) Em 1830, por exemplo, o governo baiano tomou providências para reservar parte do mercado de trabalho para a mão de obra livre, proibindo os escravos de executarem certas atividades. (FRAGA FILHO, 1999, p. 26) Entretanto, alguns trabalhos manuais eram vistos com preconceito, principalmente por estarem relacionados aos negros e aos escravos em particular. Mesmo assim, acredito que o trabalho prisional não foi contraditório ou tenha dificultado a implantação das idéias penitenciárias na Bahia. Essa minha interpretação contradiz a opinião de Patrícia Aufderheide. Para a autora, "uma grande ambigüidade rondava o papel da instituição penal, que enfatizava o valor do trabalho numa sociedade onde o trabalho manual era a marca da pobreza, discriminação racial e da escravidão”. (AUFDERHEIDE, 1976) Proponho que a discussão do trabalho prisional deva ser relacionada à 
trajetória da sociedade brasileira rumo ao trabalho livre e não analisá-la à luz da escravidão, o que pode nos levar a uma visão reducionista.

Desde o fim do século XVIII, Salvador já contava com a Casa Pia Colégio de Órfãos de São Joaquim, que foi a principal formadora de trabalhadores assalariados da cidade. (MATTA, 1999) Essa instituição privilegiava a admissão de menores brancos e mulatos, excluindo os negros, dificultando que estes ingressassem no mercado de trabalho livre que despontava na cidade de Salvador no século XIX. (MATTA, 1999) De qualquer forma, a população livre se sentia constrangida em executar certos ofícios que a equiparassem à condição de escravos. Porém, não era qualquer trabalho que era recusado. Segundo Matta, a mão de obra qualificada, no século XIX, era escassa por exigir "trabalhadores treinados e até alfabetizados, portanto, muito difícil de se achar entre os escravos". (MATTA, 1999, p. 204) Para Matta, os ofícios especializados como o de carpinteiro, marceneiro, ferreiro, alfaiate, sapateiro, caldeireiro e funileiro eram mais ocupados por pessoas livres do que por escravos os quais, geralmente, eram designados para "ofícios mais pesados da construção civil e aos menos especializados" como pescador, calafate, carvoeiro, pedreiro, servente, etc. Alguns ofícios eram mais comuns do que outros como, por exemplo, o de sapateiro, que exigia menos estudos. Já o ofício de marceneiro, especializado na fabricação de móveis, "era mais valorizado do que o de carpinteiro que trabalhava com madeira, porém de um modo mais rústico, fornecendo material destinado à construção civil”. (MATTA, 1999, p. 171) Vale destacar que a primeira oficina da penitenciária a entrar em atividade foi a de marcenaria.

Com a inauguração da Casa de Prisão com Trabalho, em 1861, prevaleceu a idéia das oficinas de ofício, contrariando a orientação da comissão constituída em 1846. Infelizmente não localizei a documentação que encaminhou para esta tomada de decisão contrária. Em 1865, finalmente foram inauguradas as oficinas de marceneiro, alfaiate, sapateiro e carapina. O regulamento da Casa de Prisão com Trabalho não mencionou o sistema penitenciário adotado, mas pode-se interpretar que se tratou do sistema de Auburn modificado. Podemos dizer que foi a adaptação da penitenciária à realidade baiana.

Em setembro de 1865, após visitar a Casa de Prisão com Trabalho em companhia do presidente da província, o chefe de polícia autorizou 
o início das atividades das oficinas de trabalho. ${ }^{11}$ Justificou sua decisão devido às reclamações dos presos de estarem "encerrados dia e noite em uma cela", com "falta de ar e exercício". ${ }^{12}$ A solução encontrada pelo chefe de polícia foi empregar nas oficinas os presos que conhecessem algum ofício; e o restante nas obras de aterro do pátio, em turmas de vinte ou trinta por dia. Neste caso foi acertado um "salário módico de duzentos a trezentos réis diários”, que seriam pagos pelo arrematador da obra. O chefe de polícia também decidiu que os trabalhadores das oficinas e das obras receberiam metade dos seus salários, enquanto o restante seria guardado em "depósito ou em uma caixa” e, posteriormente, entregue ao preso depois de cumprida a sentença; ou à família, "quando a pena de prisão não fosse temporária, ou o preso falecesse". ${ }^{13}$

No dia 23 de outubro de 1865, foram feitos os primeiros ensaios na oficina de marceneiro com os presos José Raimundo, Antonio Manuel do Nascimento Silva Monte Negro, Manoel Constantino Cardoso e Avelino José Jerônimo. Esses presos operários, como se auto denominavam, tinham a tarefa de "fazer os móveis, precisos para montar as outras oficinas". ${ }^{14}$ Cinco dias depois, Avelino foi substituído por outro preso, o escravo Cassiano. O motivo do afastamento teria sido o seu "mau comportamento". ${ }^{15}$ Este poderia ser os primeiros sinais de resistência ao trabalho prisional. Quanto ao escravo Cassiano, sabemos que não era sentenciado à prisão com trabalho, pois o Código Criminal era bem claro quanto à proibição de escravos cumprirem este tipo de pena. A sua presença na oficina é mais um indício da adaptação do sistema penitenciário à realidade prisional da Bahia. Apesar de serem poucos os escravos na penitenciária, eles existiam e eram, geralmente, pessoas condenadas à pena de morte que aguardavam pedido de graça feito do imperador ou condenados às galés. Os mestres de oficio eram escolhidos entre os profissionais da cidade e o primeiro a assumir a oficina de marcenaria foi José Polibio da Rocha que permaneceu neste

11 Chefe de polícia para o presidente da província, (04/09/1865), APEBa, Cadeias, 1836-1868, maço 3082. 12 Chefe de polícia para o presidente da província, (04/09/1865), APEBa, Cadeias, 1836-1868, maço 3082 13 Chefe de polícia para o presidente da província, (04/09/1865), APEBa, Cadeias, 1836-1868, maço 3082. Arrematantes eram os particulares que firmavam contrato de serviços com a Casa de Prisão com Trabalho.

14 Chefe de polícia para o administrador da CPCT, (23/10/1865), APEBa, Casa de Prisão, 1865, maço 5926.

15 Chefe de polícia para o administrador da CPCT, (28/10/1865), APEBa, Casa de Prisão, 1865, maço 5926. 
cargo por muitos anos. Em 1865, o valor da sua diária de trabalho era de 1200 réis mais a $3^{\mathrm{a}}$ parte do produto manufaturado. ${ }^{16} \mathrm{Um}$ mês depois, chegaram os primeiros presos aprendizes, Bernardino Gil d'Andrade e João Mathias dos Santos. Em seguida, começaram a funcionar as oficinas de alfaiate, sapateiro e carapina. Foram nomeados como mestres, respectivamente, Augusto do Amaral, o ex-guarda da Casa de Prisão com Trabalho Braz Diogo das Chagas e Rufino Marques Carvalho. ${ }^{17} \mathrm{Na}$ oficina de sapateiro foram empregados dez presos. ${ }^{18} \mathrm{~A}$ escolha da especialidade das oficinas estava relacionada aos produtos necessários à infra-estrutura da penitenciária. O artigo 110 do regulamento previa a existência de "oficinas convenientes, preferindo-se as que menos complicadas forem e maior extração acharem os seus produtos”. (CASA DE PRISÃO DA BAHIA, 1863, art. 110) No Rio de Janeiro, a escolha das oficinas também foi ditada pela necessidade dos produtos. Segundo o Diretor da penitenciária da Corte, Miranda Falcão, os presos deveriam "confeccionar aquilo de que o estabelecimento tem necessidade”. (PESSOA, 2000, p. 90)

O regulamento da Casa de Prisão com Trabalho determinou horário rigoroso para o funcionamento das oficinas. No verão os trabalhos deveriam começar às 05h30min e, no inverno, às 06h30min da manhã com intervalo para o almoço e jantar, sendo encerrado o expediente às 05h30min no verão e às 06h30min da tarde no inverno. Antes do início dos trabalhos era feita a oração matinal e, em seguida, os chefes das oficinas conduziam as turmas para as respectivas oficinas. (PESSOA, 2000) A rotina do trabalho era orientada pelo toque de uma sineta onde o número de badaladas indicava as atividades. ${ }^{19}$ Ao término dos trabalhos, os presos tinham que arrumar as ferramentas. Para se ausentar das oficinas, por qualquer necessidade, o preso teria que pedir autorização a um guarda. Durante o trabalho, os presos só podiam se comunicar caso houvesse necessidade de pegar alguma ferramenta ou, se aquele que estivesse aprendendo um ofício precisasse falar com o

16 Chefe de polícia para o administrador da CPCT, (03/11/1865), APEBa, Casa de Prisão, 1865, maço 5926.

17 Ofícios do chefe de polícia para o administrador, (27/10/1865), (07/11/1865), (22/11/1865), APEBa, Casa de Prisão, 1865, maço 5926.

18 Chefe de polícia para o administrador, (22/11/1865), APEBa, Polícia, Casa de Prisão, 1865, maço 5926. 19 “Aditamento ao Regulamento interno das oficinas da Casa de Prisão com Trabalho", APEBa, Relação de Presos, 1862-1867, maço 6272 . 
mestre, isso deveria ser feito em "voz baixa e respeitosamente". Quando não estivessem próximo ao mestre, para falar com ele, deveriam bater palmas uma vez e aguardar que este se aproximasse. (CASA DE PRISÃO COM TRABALHO DA BAHIA, 1863) Tipo de exigência que visava a subordinação e o controle dos presos operários. A documentação informa que esse rigor disciplinar acontecia na prática. Aliás, é importante destacar que a prisão baiana oitocentista era um lugar de ordem e de desordem a depender das parcerias, das negociações ou da falta destas. (TRINDADE, 2009)

\section{Concluindo}

Na Casa de Prisão com Trabalho da Bahia, a prática não correspondeu às expectativas das autoridades baianas. No final da década de 1870, uma série de escândalos envolvendo corrupção de funcionários e descontrole dos presos trouxe à tona irregularidades no funcionamento das oficinas. O administrador Manoel Diniz Villas Boas, após ser exonerado acusado de desviar os dinheiros das oficinas, tornou público, em 1867, que o trabalho prisional era facultativo aos presos, quando deveria ser obrigatório, e os mestres das oficinas não cumpriam horários. Estes últimos seriam coniventes com a traficância interna, promovida por funcionários da guarda e da enfermaria. Muitos presos só eram recolhidos à noite e, durante o dia, ficavam na rua jogando ou em companhia de mulheres. Os sentenciados se

constituíam correspondentes do Alabama, onde faziam inserir insultos e os maiores sarcasmos contra a administração e mais empregados do Estabelecimento. Condenados, enfim, que se dirigiam por meio de representações aos Ministros da Coroa, queixando-se do Ajudante do mesmo estabelecimento, e imputando-lhe fatos os mais torpes e horrorosos". Villas Boas descreveu o pátio da penitenciária como sendo uma verdadeira "quitanda, onde tinha franco ingresso um sem número de pretas com tabuleiros e caixinhas. (VILLASBOAS, 1868, p. 6)

As denúncias se seguiram, reforçando ainda mais que a comunidade prisional estava longe de ser um espaço de calmaria e dominação como os reformadores e as autoridades provinciais esperavam que fosse. 
A implantação do trabalho prisional não se resumia a ensinar um ofício ao condenado. Esperava-se que o trabalho fosse um instrumento disciplinador para condicionar o preso a receber ordens e cumpri-las tal como ele, mais tarde, deveria se comportar na vida em sociedade. O aproveitamento do tempo dos presos, através do trabalho, anunciou uma nova etapa na história da prisão na Bahia. Tentava-se combater o antigo modelo de aprisionamento, que castigava sem incluir um projeto de reabilitação. Porém, não podemos perder de vista que a reforma prisional na Bahia, e no Brasil de um modo geral, não significou uma ruptura das práticas de punição coloniais, regidas pelo Livro V das Ordenações Filipinas. Junto com o projeto de recuperar o condenado, as leis criminais do Império do Brasil mantiveram penas contrárias a esse princípio, como a de morte, galés perpétua e desterro, todas elas inerentes ao antigo regime prisional. Vale frisar que essa continuidade não foi exclusividade do Brasil. O mesmo ocorreu em países considerados referência da reforma prisional tal como a Inglaterra, os Estados Unidos e a França. Quanto aos modelos estrangeiros - Auburn e Pensilvânia --, a instituição não seguiu, na íntegra, a nenhum deles. Diria que, no máximo, o sistema de Auburn foi adaptado à realidade prisional da Bahia, para não negar totalmente a influência do modelo norte americano. Por fim, acredito que não devemos julgar se a experiência da penitenciária na Bahia fracassou ou não, como alguns autores insistem em fazê-lo. Entendo que ela se adaptou aos interesses locais, como ocorreu com todas as outras idéias e reformas "liberais" no Brasil oitocentista.

\section{Referências}

AGUIRRE, Carlos. The Criminals of Lima and Their Worlds: The Prison Experience, 1850-1935. Durham: Duke University Press, 2005.

AUFDERHEIDE, Patrícia. Order and Violence: Social Deviance and Social Control in Brazil, 1780-1840. 1976. Tese (Doutorado) - University of Minnesota, Minnesota, 1976.

BEAUMONT Gustave de, TOCQUEVILLE. Du système pénitentiaire aux États-Unis et de son application en France, suivi d'un appendice sur les colonies pénales et de notes statistiques. 2. éd.. Paris: Impr. de H. Fournier, 1833. Paris: C. Gosselin, 1836. v. 2. 
BRASIL. COLLEÇÃO das Leis do Império do Brazil. Rio de Janeiro: Typografia Nacional, 1878.

CASA DE PRISÃO COM TRABALHO DA BAHIA. Regulamento da casa de prisão com trabalho da Bahia. Bahia: Typ. Poggetti - de Tourinho; Dias \& C, 1863; Bahia: Typ. Poggetti, 1863. Aprovado pelo presidente da província o conselheiro Antonio Coelho de Sá e Albuquerque em 14 de outubro de 1863

COELHO, Edmundo Campos. As profissões Imperiais: medicina, engenharia e advocacia no Rio de Janeiro 1822-1930. Rio de Janeiro: Record, 1999. p. 155, 157

FILGUEIRAS JUNIOR, Araujo. Código Criminal do Império do Brazil Annotado. Rio de Janeiro: Eduardo \& Henrique Laemmert, 1876.

FRAGA FILHO, Walter. Mendigos, moleques e vadios na Bahia do século XIX. Salvador: EDUFBA, 1999.

FOUCAUT, Michel. Vigiar e punir: história da violência nas prisões. 5. ed. Petrópolis: Vozes, 1987.

FOUCAULT, Michel, Prisões e revoltas nas prisões, In: MOTA, Manoel 28 Barros da (Org). Michel Foucault, estratégia, poder-saber. Rio de Janeiro: Forense Universitária, 2003, p. 67.

DUPRAT, Catherine. Punir e curar - em 1819, a prisão dos filantropos. Revista de História, v.7, n.14, p. 7-58, 1997.

LEAL, Maria das Graças de Andrade. A arte de ter um ofício: Liceu de Artes e Ofícios da Bahia (1872-1996). Salvador: Fundação Odebrecht / Liceu de Artes e Ofícios da Bahia, 1996.

LUCAS, Charles. De la réforme des prisons, ou de la théorie de l'emprisonnement, de ses principes, de ses moyens et de ses conditions pratiques. Paris: E. Legrand et J. Bergounioux, 1836-1838. v. 3

KRAAY, Hendrik. Race, State, and Armed Forces in Independence-era Brazil: Bahia, 1790's-1840's, Stanford: Stanford University Press, 2001.

MARSON, Izabel Andrade. Liberalismo versus escravidão: reflexões sobre uma relação contraditória. História e Perspectivas, v. 24, p. 39-50, 2002.

MATTA, Alfredo Eurico Rodrigues. Casa Pia Colégio de Órfãos de São Joaquim: de recolhido a assalariado. 1996. 228 f. Dissertação (Mestrado em História) - Universidade Federal da Bahia. 1996.

MATTOS, Ilmar Rohloff de. O Tempo Saquarema: a formação do Estado Imperial. São Paulo: Hucitec, 1990. 
MATTOSO, Kátia M. de Queirós. Bahia: a cidade do Salvador e seu mercado no século XIX. São Paulo: Hucitec, 1978.

MCGOWEN, Randall. The Well-Ordered Prison: England, 1780-1865. In MORRIS, Norval; ROTHMAN, David J. (Org.) The Oxford History of the Prison. New York: Oxford University Press, 1995. p.79-109.

PERROT, Michelle. Os excluídos da história: operários mulheres e prisioneiros. 3. ed. São Paulo: Paz e Terra, 2001.

PESSOA, Gláucia Tomaz de Aquino. Trabalho e resistência na penitenciária da Corte 1850-1876. Dissertação (Mestrado em História) Universidade Federal Fluminense, 2000.

ROTHMAN, David J. Perfecting the Prison: Unides States, 1789-1865. In: MORRIS, Norval;ROTHMAN, David J. (Org.), The Oxford History of the Prison. New York: Oxford University Press, 1995.p. 100-116.

REIS, João José. Rebelião escrava no Brasil: a história do levante dos Malês em 1835. Edição Revista e Ampliada. São Paulo: Companhia das Letras, 2003.

RIOS, Venétia Durando Braga. O Asylo de São João de Deus: as faces da loucura. 2006. Tese (Doutorado em História) - Pontifícia Universidade Católica de São Paulo, São Paulo, 2006.

SALLA, Fernando. Os escritos de Alexis de Tocqueville e Gustave de Beaumont sobre a prisão: o problema da participação dos negócios privados. Revista Plural, v. 1, p. 1-16, 1994.

. O Encarceramento de São Paulo: das enxovias à Penitenciária do Estado. 1997. 286 f. Tese (Doutorado em Sociologia) - Departamento de Sociologia da Faculdade de Filosofia, Letras e Ciências Humanas, Universidade de São Paulo, São Paulo, 1997.

. As prisões de São Paulo: 1822-1940. São Paulo: Anablume, 1999.

SILVA, Mozart Linhares da. Do império da lei às grades da cidade, Porto Alegre: EDIPUCRS, 1997.

SOARES, Carlos Eugênio Líbano. A Capoeira escrava e outras tradições rebeldes no Rio de Janeiro, 1808-1850. Campinas: Editora da Unicamp, 2003.

SYSTEMA PENITENCIÁRIO. Bahia: Typographia de Galdino Joze Bizerra, e Companhia, 1847. Relatório. Feito em nome da commissão encarregada, pelo Presidente da Provincia, de examinar as questões relativas à Casa de Prisão com Trabalho, da Bahia. 
TRINDADE, Cláudia Moraes. A Casa de Prisão com Trabalho da Bahia, 1833-1865. 2007. 172 f. Dissertação(Mestrado em História Social) Programa de Pós-Graduação em História Social, Universidade Federal da Bahia, Salvador, 2007.

. A reforma prisional na Bahia oitocentista. Revista de História, n158, p. 157-198, 2008.

. Para além da ordem: o cotidiano prisional da Bahia oitocentista a partir da correspondência de presos. Revista História/São Paulo. Dossiê: História, Direito e Justiça. v. 28, n. 2, 2009. (no prelo).

VASCONCELLOS, Joaquim. Fala que recitou o presidente da província da Bahia. [2 fevereiro 1842],Typ J. A. Portella e Companhia. p. 5.

VILLASBOAS, Manoel Diniz [Carta] 12 fev. 1868, Bahia [para] Presidência da Província da Bahia, Bahia: Typographia Constitucional de França Guerra, 1868, f. 5-6. Resposta apresentada pelo ex-administrador da Casa de Prisão com Trabalho da província da Bahia, tenente-coronel Manoel Diniz Villasboas, no processo de responsabilidade a que foi submentido por acto da presidencia da mesma província. 


\section{Prisões e globalização}

António Pedro Dores

\section{Introdução}

Para alguns autores a globalização é um processo que começou há meio milénio, com os Descobrimentos. Para outros ele é bem mais recente, já que sem a industrialização e a colonização que a suportou, faz pouco mais de duzentos anos, não haveria a possibilidade de aceleração de trocas que permite actualmente as economias de todo o mundo concorrerem em tempo real e à distância. Mais em tempos mais próximos de nós, a revolução dos transportes, o caminho-de-ferro, as estradas para automóveis e a aviação civil, bem como a revolução informática, ou a organização de mercados financeiros, primeiro nacionais e depois globais, infraestruturaram aquilo que é a globalização actual, que também passa pela mediatização de uma agenda global e pela concorrência em tempo real das actividades profissionais mais qualificadas, como nas áreas da consultoria, da ciência e tecnologia, da saúde, do ensino superior, para não falar do crime organizado. A globalização manifesta-se em fenómenos como a Internet, a expansão do inglês e do dólar (eventualmente do euro) como língua e moeda francas, mas também nos efeitos globais do efeito de estufa, das mudanças climáticas, da exclusão social - incluindo destruição de modos de vida tradicionais, as migrações, as fomes, as sedes - ou da guerra por petróleo.

As lutas da era da globalização opõem os neo-liberais, apostados na liderança do governo federal norte-americano, detentor de meios de coerção inigualáveis para evitar formas de regulação que não sejam do seu interesse, aos que preferem desenvolver políticas multilaterais. Observando esta oposição do ponto de vista da análise do que possa 
influir nos sistemas prisionais, é sabido como os EUA admitem a pena de morte como pena regularmente aplicada por vários Estados e como nos últimos anos se tornou um debate político a legalização da tortura (que de facto avançou nas instâncias legislativas federais norte-americanas) como forma de extrair confissões a presumidos terroristas, amigos de terroristas ou pessoas que de alguma forma possam ter vivido (saibam disso ou não) alguma situação cuja descrição possa ser útil aos caça-terroristas. A ambas as tendências, cuja persistência e desenvolvimento se organizam em doutrina judicial alternativa àquela que é reconhecida actualmente no ocidente, se opôs explicitamente a ONU, ainda que de maneira precária e incapaz de impedir o avanço da onda securitária lançada, sobretudo, a partir dos atentados de 11 de Setembro de 2001 nos EUA.

A proposta doutrinária liderada actualmente pelo governo federal norte-americano implica retornar, do ponto de vista jurídico, à sociedade de ordens, em que as pessoas, consoante o respectivo estilo de vida e estatuto social (por exemplo, se são nacionais norte-americanos ou não, se têm fenótipo africano ou espânico ou do médio oriente ou outro que seja considerado exótico) têm acesso a diferentes sistemas jurídicos. Na avaliação de Jakobs e Meliá (2003): um sistema para julgar crimes económicos, ditos de colarinho branco, em que as penas de prisão tendem a cair em desuso; outro para julgar os crimes de trabalhadores, que pagam com prisão os seus crimes; um terceiro sistema concebido para julgar terroristas, em que os direitos de defesa, tal como os conhecemos actualmente, deixam de estar garantidos, até porque à partida, para entrarem no subsistema judicial nessa condição, é porque o princípio da presunção de inocência já foi invertido. Guantanamo e as prisões secretas espalhadas pelo mundo pelo governo federal norte-americano para escapar à jurisdição do poder judicial do seu país são consequências práticas da aplicação de tais políticas, em contradição com a doutrina oficial do sistema judicial vigente.

Neste cenário, é possível manter a neutralidade? Sim, é a resposta.

A União Europeia, por exemplo, reage lentamente e arrasta os pés à cumplicidade denunciada por Collin Powel, ex-secretário de Estado de George W. Bush, a respeito das prisões secretas que aceitou no seu próprio território. Ao mesmo tempo que não se coíbe, por seu turno, de organizar, com países do norte de África, sistemas de controlo das 
ondas de imigração que alimentam os mercados de mão-de-obra barata do Sul da Europa, incluindo o uso da força arbitrária. ${ }^{1}$

Os opositores da guerra no Iraque, denunciadores das torturas em Abu Grahib, tantas vezes considerados anti-americanos pelos que defendem políticas securitárias, hesitam perante, ou simplesmente não notam, o facto de tais torturas serem também praticadas nas prisões em território dos EUA, (PERKINSON, 2004; BUTTERFIELD, 2004). Da mesma forma que as práticas de tortura condenadas pela ONU em Espanha são ignoradas pelas autoridades democráticas do país vizinho de Portugal, que tomaram o poder contra a guerra no Iraque. ${ }^{2}$

Quanto mais perto da órbita de responsabilidade própria de cada um, mais se torna repugnante, embaraçoso e difícil reconhecer (para não falar em combater) as práticas de abuso de autoridade, em especial a das autoridades de segurança que, implicitamente, nos aparecem tanto mais directamente ameaçadores quanto mais arbitrários sejam os seus comportamentos conhecidos.

Esta experiência, a que chamamos segredo social, fenómeno social vulgar que obscurece na consciência de cada ser humano as percepções que respeitam a realidades quotidianas imorais, ameaçadoras, terríveis, merece uma identificação e explicações mais detalhadas, para o que contribuiremos mais adiante. Insistimos, para já, na ideia de que a abordagem a temas prisionais feita sem a consciência de estes serem sintomáticos do decurso de lutas sociais de grande profundidade emocional, histórica e civilizacional, se reduz, com prejuízo de sentido, às políticas e vidas prisionais em sentido estrito. O saber como se vive em e como funcionam as prisões depende da capacidade que se tenha de perspectivar teoricamente o que passa no interior dessas instituições, em função do sentido geral da vida em sociedade.

Pode parecer muito abstracta ou ideológica esta última declaração. Mas a verdade muito prática é só uma: com tantos entraves para observar o que se passa nas prisões, instituição onde todos parecem ter excelentes razões para esconder tudo, não é o olhar - por muito experimentado e sagaz que possa ser - do cientista social que vai con-

1 Em Marrocos, no final de 2006, um grupo de candidatos a imigrantes foi abandonado à sua sorte no deserto pelas autoridades do país, apoiadas e instigadas por um convénio que troca dinheiro europeu pela colaboração na redução do número de imigrantes africanos, incluindo métodos ilegais e letais.

2 Para informações sobre a situação da tortura em Espanha ver < http://www.nodo50.org/tortura/ $\operatorname{spip} />$. 
seguir descortinar o essencial, muitas vezes inclusivamente o básico. Caso a sociedade, ela própria, não produza os meios técnicos de observação das instituições e das vidas prisionais, por exemplo, através do acolhimento e tratamento sistemática das denúncias, nomeadamente em instituições independentes e empenhadas na prevenção contra a tortura, a ciência por si só não terá a capacidade de estabelecer postos de observação descomprometidos com as próprias condições institucionais de encarceramento e, portanto, com as tendências securitárias actualmente dominantes em todo o mundo. Mas a ciência pode distanciar-se - como aconselham os mestres - e utilizar os dados empíricos de forma a reconstruir, na imaginação e nos conhecimentos fundamentais sobre a natureza humana, aquilo que pode ser descoberto pelos métodos científicos.

Mesmo se as tendências sociais dominantes fossem de desencarceramento, como eram por ocasião dos anos sessenta e setenta, quando as ideias abolicionistas das penas de prisão pareciam realizáveis através da institucionalização das penas alternativas à prisão, a ideia comum sobre as prisões era (como ainda é actualmente) de que todas as prisões são iguais umas às outras e sempre assim foram e serão. É mérito da ciência, e em particular de Michel Foucault (1999) e mais recentemente de (CUNHA, 2002), mostrar que a história das prisões modernas é muito recente e atribulada, ao contrário do senso comum.

A ideia estereotipada e estilizada das prisões é um fenómeno global que acompanha (e explica?) a difusão e adopção da ideia de sistema penal, como uma forma de dar uma imagem de racionalidade higienista da justiça e da moral social, capaz de reduzir à anormalidade, à criminalidade, à marginalidade, ao outro menorizado, muitas das causas dos problemas e dissidências sociais. Tal efeito (ao mesmo tempo psicológico, social e político) resiste e persiste porque - ao contrário do que acontecia anteriormente, quando as penas eram executadas como espectáculos públicos - o sistema penitenciário permite reforçar a repugnância social pelos criminosos (e pelos carcereiros) com o segredo social, isto é, o compromisso profissional e social, técnico e político, jornalístico e científico, de imaginar (mais do que observar) os (melhores) funcionamentos institucionais e as (melhores) vidas na prisão. Por exemplo, embora toda a gente saiba que as prisões se tornaram, nas últimas décadas, os supermercados de drogas mais lucrativos - o que é 
também um fenómeno global decorrente das políticas proibicionistas, doutrinariamente sediadas na ONU, como acontece com as políticas de prevenção contra a tortura - continua a imaginar-se que os muros da prisão são um sistema de segurança impenetrável. De outra maneira não seria possível continuar a pensar como racional a estratégia de perseguição policial para conter os vícios privados, até porque os factos mostram, à evidência, os efeitos perversos de tal política. ${ }^{3} \mathrm{O}$ que acontece, porém, é que a ideia intencionalmente simplista do que sejam as prisões, possibilitada pelos segredos sociais que se organizam em torno da justiça, das polícias, do Estado e das acções repressivas, e imposta pela lógica intimidatória própria da política de monopólio da violência legítima por parte das instituições do Estado, por vezes confundida ou misturada com o efeito de persuasão e prevenção criminal que só a autoridade do Estado tem capacidade para desenvolver, tal ideia simplista das prisões, dizia, funciona (simbólica e ideologicamente) como uma espécie tampa de ralo sem a qual todo o sistema político e judicial ameaça desmoronar-se. Sem a possibilidade de obrigar a penar os arguidos, os magistrados teriam de aprender a manifestar o seu poder de outros modos, quem sabe como fazem os professores - através de juízos de valor aplicados em escalas de zero a vinte. Para o que precisariam de outro tipo de autoridade do que aquela a que hoje em dia dispõem.

As resistências à observação das prisões são, portanto emocionais, históricas e civilizacionais, antes de serem políticas e científicas. Estão profundamente enraizadas na humanidade de cada leitor e de cada investigador e mexem com os sentimentos de segurança de cada um. Para exemplificar o que se quer dizer, experimente-se organizar uma palestra sobre a sociedade sem prisões. Logo aparecerão curiosos incrédulos a perguntar: o que fazer com os criminosos? Ou mobilize-se a experiência de participação no fórum social mundial (FSM). Questione-se como são tratadas as questões prisionais no meio da cacofonia que procura meios de organizar uma globalização alternativa. $\mathrm{O}$ facto é que não são tratadas, a não ser marginalmente, como fenómenos locais e exóticos, as questões prisionais. O autor destas linhas teve oportunidade de perguntar, num seminário sobre criminalização dos pobres, em Porto Alegre, Janeiro de 2002, se num "outro mundo possível" as prisões poderiam ser abolidas. A resposta, aparentemente consensual na mesa

3 Sobre o tema vale a pena ler Michael Woodiwiss (1988, 2005) e Klahr (2006). 
sul-americana, foi surpreendente: "Sem prisões, onde passariam a viver, uma vez mudado o regime político, os que nos fazem viver clandestinos com receio de sermos presos e torturados?" (citado de cor e em versão livre). Pelo tratamento da mesma questão, membros de uma associação de direitos humanos andaluza interessada em questões prisionais procuraram, e também o que encontraram, em Nairobi, Janeiro de 2007, onde se reuniu o FSM, foram referências sem centralidade doutrinária, filosófica, política, analítica. ${ }^{4}$ Todavia, há movimentos que avançam no combate de fundo da preservação e aprofundamento dos princípios doutrinários da igualdade perante a lei e do respeito pelo Estado de Direito, cujas principais realizações podem ser observadas nas prisões, como se fossem laboratórios sociais. ${ }^{5}$ Em particular, os movimentos globais de prevenção contra a tortura, mobilizados em torno do Protocolo Adicional à Convenção contra a Tortura e outros Tratamentos ou Penas Cruéis, Desumanas ou Degradantes, que entrou em vigor porque foi subscrito e ratificado por vinte países - em meados de 2006. Tal protocolo prevê a necessidade de intensificação e alargamento da organização de prevenção de práticas ilícitas, divulgando localmente a experiência das inspecções internacionais que a ONU já praticava anteriormente, mas de forma esporádica e rara, dada a escassez de meios para intervir em todo o mundo e, também, as limitações de conhecimento que os peritos independentes que trabalharam nessas funções tinham sobre as especificidades locais, isto é, o desconhecimento das queixas e alegações, bem assim como os meios de encobrimento ou de protecção dos perpetradores das ilegalidades a prevenir. A partir da entrada em vigor do Protocolo Adicional espera-se que a mobilização de pessoas e organizações contra a tortura as possa colocar, com apoio político do Estado mas sem a sua interferência directa, como prevê o tratado livremente subscrito pelos Estados signatários, em posição de intervir de forma mais institucionalizada e sistemática, com o máximo de conhecimento de causa, conforme as melhores práticas entretanto desenvolvidas na ONU, no sentido de abolir as práticas de tortura.

4 A luta contra o neo-liberalismo económico pode obstruir a luta pelo liberalismo judicial, doutrinariamente igualitário, e constituir assim um segredo social suplementar, de natureza ideológica, para os activistas da alter-globalização, a somar ao segredo social que já recobre os temas judiciários em geral.

5 É costume dizer-se que as prisões estão para as sociedades como as drogas e o jogo estão para as pessoas: revelam-lhes os atributos de carácter mais profundos ou, o que é o mesmo dito de outra forma, os atributos que estão sujeitos a regimes de segredo social, de estratégias de encobrimento social. 
Tais avanços poderão explicar a necessidade do governo federal norte-americano de legalizar certas formas de tortura já anteriormente praticadas (não apenas nos EUA), impedindo desse modo, ou pelo menos dificultando antecipadamente, eventuais denúncias de desrespeito pela lei por parte dos Estados e abrindo mais campo a práticas de encobrimento, com base na alargada ambiguidade legal.

\section{Crescimento global do número de prisioneiros}

Nove e um quarto milhões de pessoas viviam na prisão em 2005, em todo o mundo, contra oito milhões em $1999 .{ }^{6}$ Alguns países, entre os quais o Brasil, viram crescer muito o número de prisioneiros nos últimos anos. Os EUA são os campeões do encarceramento, com 2,19 milhões de prisioneiros, seguidos da China e da Rússia, com 1,55 e 0,87 milhões respectivamente. Estes números são por um lado impressionantes pelo seu volume - é como se o mundo tivesse reservado um canto do tamanho de Portugal (que conta com 10 milhões de habitantes) para fazer aí o seu inferno - mas provavelmente conservadores, já que existe uma competição mundial para evitar contas altas. Nos EUA, por exemplo, os presos sob a tutela do executivo, em Guantanamo, nas prisões secretas dentro e fora do território, não são contabilizados. A notícia do relatório britânico que cita os números referidos acima menciona que para as informações chinesas apenas são contados os condenados e os que estão em detenção administrativa. Presume-se que faltarão nessas contas outras pessoas igualmente sem liberdade por decisão do Estado, eventualmente em campos de educação.

Note-se, isso é relevante, que os números, e principalmente a sua explicação e interpretação mais detalhada, colocam problemas emocionais importantes. Caso o leitor não goste das políticas dos EUA ou do próprio povo norte-americano, é-lhe fácil de interpretar o facto de haver tantos presos (seja pela incapacidade de orientarem as suas vidas e a sociedade em geral, seja pelo reconhecimento nestes números dos prazeres mórbidos e perversos que tal povo alegadamente alimentará). Para defesa dos EUA haverá outros argumentos, como seja o facto de a generalidade dos detidos (perto de metade) serem negros, o que pode

6 Segundo estimativas divulgadas por Walmslay (2010). 
remeter para o passado, para África, e definitivamente para o carácter dos condenados, a explicação de tais números. Na China, onde não há negros em quantidade suficiente, se se disser que há tortura e brutalidades em massa nas prisões, que nas próprias fábricas os trabalhadores não são respeitados e os direitos humanos de todos não são defendidos, e só raramente alegados, a tendência para dar crédito, ou pelo menos dar de barato, que isso possa estar a acontecer na China é sensivelmente maior do que se se tratasse de um país ocidental. Quanto mais próximo de nós, mais difícil é reconhecer (apesar das notícias) o que possa estar a acontecer, apesar da disponibilidade da informação ser, evidentemente, maior.

As informações sobre os sistemas prisionais no mundo são problemáticas porque são recolhidas com métodos diferentes, de acordo com os respectivos critérios judiciais e criminais em vigor, os critérios estatísticos em uso, os interesses políticos de cada Estado e a respectiva capacidade de interferência, maior ou menor, na divulgação dos trabalhos estatísticos. São problemáticas porque mexem de perto com as nossas emoções humanas mais fundamentais, de sobrevivência, de solidariedade, de submissão e cooperação, de legitimação do uso da violência, vinculadas de modo intenso com as identidades nacionais e de classe de cada um e com os fundamentos do Estado num sentido pouco racional, como é aquele a que se fez menção anteriormente. É a própria crença na racionalidade judicial e penal, sem cuja legitimidade as instituições fundamentais do Estado moderno se podem tornar ou serem sentidas (o que é o mesmo) como periclitantes que está em causa, para os responsáveis judiciais e políticos mas também - e sobretudo para as cidadãos. A defesa do estado das prisões é, no seu sentido mais radical, a defesa do Estado, incluindo a defesa do estado de coisas e dos sentimentos de segurança tanto mais necessários e desejados quanto pairem sentimentos sociais de insegurança.

Para o jornal on line About, a população prisional norte americana é de 1,5 milhão de pessoas. ${ }^{7}$ Para a Human Rights Watch a população prisional norte-americana é de 2,3 milhões. ${ }^{8}$ Provavelmente ambos os números estão certos, pois contarão populações diferentes, embora sob a mesma designação. Mas as diferenças nos resultados não são negli-

7 <http://crime.about.com/od/prison/a/blbjs041107.htm >. GERARD, 2005)

$8<$ http://www.hrw.org/news/2006/11/30/us-addiction-incarceration-puts-23-million-prison> (FELLNER,2006) 
genciáveis. Cada qual, consoante a tese que pretenda ilustrar, prefere utilizar as referências mais convenientes, seja à maximização do efeito contabilístico - por se entender deverem ser contadas todas as situações de restrições de liberdade, independentemente dos regimes serem mais fechados (como as celas brancas de que praticamente não se sai, mantido sem referências de modo a provocar perturbações mentais) ou mais abertos (com permissão para trabalhar e estudar fora do recinto prisional) - seja à sua minimização - por se entender que em certas condições de detenção não há castigo mas antes um serviço de reabilitação, desígnio que acompanhou sempre as intenções declaradas nas reformas penitenciárias. O trabalho com estatísticas, especialmente no caso das prisões, é emocionalmente tão carregado que mesmo quando se tratam números tão gerais como os referenciados as diferenças podem ser estas.

Se acontece no EUA, também pode acontecer com todas as estatísticas de outros os países. Ainda assim é possível contabilizar os volumes relativos de encarceramento em diversos países do mundo e saber que o Japão (embora esteja a viver um período de forte incremento do número de presos, na sequência da crise política e social estrutural que tem vivido na última década e meia) e os países nórdicos na Europa são onde o uso das prisões é tradicionalmente menor.

Quadro 1- População prisional por 100,000 habitantes ${ }^{9}$

\begin{tabular}{|c|c|c|c|c|c|c|c|c|c|c|c|}
\hline E⿱乛龰 & 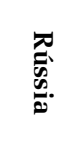 & 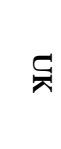 & 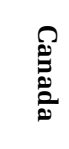 & 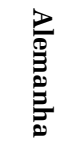 & 홓 & 武 & 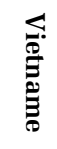 & 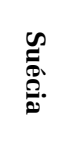 & 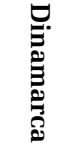 & 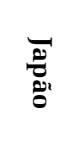 & 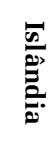 \\
\hline 740 & 713 & 124 & 102 & 98 & 92 & 80 & 75 & 64 & 61 & 37 & 29 \\
\hline
\end{tabular}

Fonte: (WIKIPEDIA, 2007)

Merece referência especial o caso da Finlândia, anteriormente na órbita política da União Soviética - tradicionalmente com taxas de encarceramento das mais altas do mundo -, que na sequência da implosão do império soviético transitou voluntariamente para a esfera de influência da União Europeia, tendo-se tornado um exemplo de estudo de sociedade da informação, Castels (2004), e, ao mesmo tempo, adoptou os padrões

$9<$ http://en.wikipedia.org/wiki/Prison\#Prisons_by_country >. (WIKIPEDIA, 2007) 
jurídicos e penais dos países nórdicos quando passou a seguir os seus padrões culturais e políticos. O autor catalão faz notar que a sociedade da informação e dos computadores, de que os EUA são o zénite, não é obrigatoriamente uma sociedade penal - como acontece na América do Norte. Na Finlândia, recém-chegada aos lugares de topo dos desempenhos informáticos industriais, prova que é possível seguir modelos de desenvolvimento bem sucedidos sem encarceramento em massa.

Voltando ao quadro 1, os números apresentados, apesar do louvor que merece o trabalho da sua compilação, têm significados que só podem ser interpretados com a observação e conhecimento das realidades locais, completados não apenas por outros números (séries estatísticas) mas também pelas filosofias políticas adoptadas em cada caso, e em especial no que toca às políticas prisionais, bem como as tendências mais recentes de evolução da situação de segurança objectiva e subjectiva. Por exemplo, o caso português, que na viragem do século era o sistema prisional com maior taxa de encarceramento da União Europeia, com mais de 140 presos por 100 mil habitantes, num 40 país com baixa taxa de criminalidade relativa oficialmente apurada, está em situação de decréscimo de população prisional (que rondará, em 2006, 120 presos por 100 mil habitantes) em contra ciclo com a Espanha, a Grã-Bretanha (em crescimento do número de presos no mesmo período, países que tomaram o lugar cimeiro na EU a Portugal) e com a França, que, apesar de não ser dos países da União Europeia com maior taxa de encarceramento, vive a circunstância de uma fase de politização da questão prisional, que é tema das campanhas eleitorais de praticamente todos os candidatos presidenciais. Em Portugal o tema da reforma prisional saiu das campanhas eleitorais em 2005, depois de estar sempre presente desde o início do século.

Estudos quantitativos sobre a relação homens/mulheres, jovens/ adultos/idosos, presos preventivos/presos condenados, primários (com uma só condenação), reincidentes (no mesmo crime, mais de uma vez condenados), presos não nacionais, número de doentes crónicos e mentais, número de utilizadores de drogas, número de presos em celas unipessoais, e em celas sem casa-de-banho, sobrelotação das cadeias, e outros, permitem produzir dados de qualidade variável. Que todavia são reunidos por pessoas como Pierre Tournier, que deles são capazes de extrair ensinamentos úteis à organização de políticas públicas, ao 
combate aos preconceitos, ao debate político elevado sobre temas tão emocionantes e profundos como as prisões.

Há, todavia, dois tópicos que são mais politicamente sensíveis que outros. Os custos das prisões (que aqui não trataremos) e o obituário prisional. Nestes campos, a ponderação entre o respeito pelo segredo social, os valores económicos e a vida humana complica-se. Em qualquer parte do mundo, um prisioneiro ferido - por efeito de torturas, de lutas ou auto-flagelação - não merece a atenção pública e política que merece um cadáver que saído da prisão.

Para quem trabalha nas prisões, quem observa as consequências práticas na vida das pessoas e as dificuldades/impossibilidades de tornear os bloqueios que degradam a humanidade dos prisioneiros (e também os guardas e funcionários), o sofrimento em vida pode fazer parecer a morte uma solução desejável. Isso mesmo se testemunhou na situação de extrema fragilidade da condição de um toxicodependente moribundo que foi deixado na sua cela, em Lisboa, durante 4 ou 5 dias sem comer - o que é contra os regulamentos - até que o desenlace ocorreu, na presença acompanhante do companheiro de cela: "Ele queria morrer" - disse um elemento do pessoal de saúde. Só não foi um escândalo público porque apenas a família pode servir legalmente de interlocutora das autoridades nestas ocasióes. Ora o pai estava preso, a mãe, muito pobre e doente, incapaz de suportar qualquer tipo de pressão mediática que seria necessária para tornar conhecido o caso. Do caso fica a lição: do que se passou antes da morte (incluindo a degradação física de um toxicodependente, como outros, que partiu um estilete que serviu de seringa artesanal numa das coxas) a oportunidade de denúncia depende do próprio, da sua capacidade de fazer circular informação e de persistir na queixa quando questionado - em reclusão - sobre isso mesmo. Na morte, a denúncia depende do conhecimento que se tenha das circunstâncias em que aconteceu e da vontade e capacidade de luta da família.

É por isso que a greve de fome é, dentro da prisão, uma arma muito requisitada pelos presos para lutarem pelo que entendem necessitar. E com efeitos práticos. Pois a má publicidade é um risco permanente a ser gerida com todo o cuidado pelas administrações penitenciárias e pelos governos. O carácter extremamente emocional dos contextos sociais de encarceramento (seja no interior, seja no exterior) produz efeitos 
historicamente conhecidos, que transformam as crises prisionais, desde que haja mortos, em notícia e comentário político. Um dos maiores temores das administrações penitenciárias, e dos governos, é a capacidade de mediatização que possam ter os eventos prisionais, que estão fechados entre muros precisamente para evitar ao máximo que isso aconteça. Porém, não são os muros que evitam que, de quando em vez, os casos prisionais se tornem casos públicos, seja a propósito de histórias fantásticas, inimagináveis noutras instituições, seja sob a forma dramática de motins e desordens recorrentes, aproveitando, perversamente, a quem disso souber tirar proveito, sejam presos ou guardas, direcção da cadeia ou traficantes, políticos ou oposição, media ou académicos estudiosos.

Quadro 2 - Taxas de mortalidade nas prisões de alguns países do Conselho da Europa

\begin{tabular}{|c|c|c|c|}
\hline $\begin{array}{l}\text { mortes por } 10000 \\
\text { prisioneiros }\end{array}$ & 1997 & 2001 & 2003 \\
\hline Portugal $^{10}$ & 106 & 79 & -- \\
\hline Rússia & 78 & 59 & -- \\
\hline Moldávia & 65 & 82 & 74 \\
\hline Letónia & 59 & 12 & 38 \\
\hline Bélgica & 59 & 36 & -- \\
\hline Dinamarca & 56 & 43 & 53 \\
\hline Bulgária & 46 & 35 & 44 \\
\hline Finlândia & 40 & 45 & 29 \\
\hline França & 37 & 49 & 40 \\
\hline Escócia & 32 & 33 & 23 \\
\hline Espanha & $31^{*}$ & 31 & 32 \\
\hline Grécia & $20^{*}$ & 40 & -- \\
\hline Itália & $30^{*}$ & 32 & 27 \\
\hline Hungria & $34^{*}$ & 237 & 29 \\
\hline Ucrânia & $74^{*}$ & 272 & 49 \\
\hline
\end{tabular}

Fonte: Deaths in penal institutions (SPACE 1, 2010) * dados do ano 2000

10 Quadro 3 Taxas de mortalidade nas prisões portuguesas, por 10 mil presos

\begin{tabular}{|l|l|l|l|l|l|}
\hline & $1997^{*}$ & $2000^{* *}$ & $2004^{* * *}$ & $2005^{* * *}$ & $2006^{* * * *}$ \\
\hline Portugal & 106 & 60 & 64 & 72 & 70 \\
\hline
\end{tabular}

*Fonte: Deaths in penal institutions (1997), Council of Europe

**Fonte: Conselho da Europa, Space 2001.12

*** Fonte: dados brutos da DGSP de 84 e 94 mortos respectivamente em 2004 e 2005, no fim do ano.

****Fonte: estimativa para o ano de 2006 com base na resposta Ministério da Justiça a requerimento do grupo parlamentar Os Verdes referente aos 6 primeiros meses do ano (45 mortos). 
Chocam mais as mortes que acontecem a pessoas jovens e antes de serem condenadas. ${ }^{11} \mathrm{O}$ que mostra que o contacto com as autoridades penais pode ser letal. Por se saber disso, de maneira oficial, digamos assim, é que os países signatários da Convenção da ONU contra a tortura declaram o seu respeito pela doutrina dos Direitos Humanos, manifestando formal e solenemente o seu acordo de princípio às práticas de prevenção da tortura, embora nem sempre a colaboração política e administrativa no local às equipes de inspecção seja exemplar. ${ }^{12}$ Esta ambiguidade política entre os desejos e as realidades (bem mais violentas e perversas do que o que estamos geralmente preparados para aceitar, seja por razões psicológicas seja por razões políticas) está na origem de escolhas ambíguas do pessoal nacional para representar os Estados signatários nas instâncias de administração das práticas preventivas. $^{13}$

Nos casos de mortes, há regularmente explicações pouco plausíveis para o sucedido que chegam à opinião pública: falta de informação qualificada e precisa sobre o que terá acontecido, incluindo disputas judiciais para apurar a verdade. Não é que o mesmo não se passe em litígios na prisão a que não estejam associados cadáveres. O que explica a diferença entre os males de que resultam mortes nas prisões e os outros, é que os primeiros são mais difíceis de esconder, na sua quietude, pois não admitem intimidações nem estigmas. Não podem ser apresentados - ainda que isso seja tentado por vezes - como perigosos para a sociedade. E os cadáveres, na sua radicalidade, podem ser contados de um modo irrecusável, ao contrário dos conflitos, por exemplo. A boa vontade com que tais contagens são feitas pode ser

11 Por exemplo: "Morto depois de menos de um dia na prisão", (JEAVANS, 2006), cf. < http:// news.bbc.co.uk/1/hi/uk/4814928.stm>. Em subtítulo escreve: "No último ano 78 homens, mulheres e jovens mataram-se na prisão em Inglaterra e Gales. Metade esperava julgamento ou decisão judicial.”. No caso, a notícia referia-se ao suicídio de um jovem de 24 anos.

12 Para uma apreciação diplomática do comportamento dos Estados perante este tipo de problemas, a nível global, ver websites das organizações globais para a prevenção da tortura, como seja a Associação para a Prevenção da Tortura <http://www.apt.ch/> ou a Organização Mundial Contra a Tortura < http://www.omct.org/>.

13 A escolha portuguesa de um antigo e controverso antigo director geral dos serviços prisionais para o comité de prevenção da tortura do Conselho da Europa ou a indigitação do governo espanhol de um antigo procurador geral envolvido na guerra suja contra a organização armada basca ETA para representar o país na nova estrutura de administração do Protocolo Adicional da Convenção contra a tortura da ONU são apenas dois exemplos mais próximos e que são do nosso conhecimento. 
percebida pela ausência de explicações sobre os números de obituário prisional e sobre as respectivas variações, que podem ser enormes, tanto entre países como de um ano para o outro no mesmo país, quadro 2.

Pode ser que as condições de detenção, sempre a braços com custos elevados, não permitam socorro de pessoal de saúde em situações de emergência; ou que a prioridade às questões de segurança também não facilitem a ajuda de presos em caso de necessidade, principalmente quando a pressão é grande sobre os serviços; nomeadamente quando há situações crónicas de sobrelotação, de falta de pessoal, que acontece frequentemente na actual conjuntura histórica dados os crescimentos sustentados dos números de presos e as limitações orçamentais globais para despesas sociais.

Não se pode dizer que não seja do conhecimento público o essencial do que se passa nas prisões. A questão é a de saber se é possível e interessa ao público, na sua relação cívica e política com o Estado, tomar conhecimento prático, assumir responsabilidades colectivas, face a realidades conhecidas e publicadas? Ou é preferível delegar nos órgãos próprios do Estado a responsabilidade de lidar directamente e por conta própria com as realidades que as sociedades, assim, podem meter debaixo do tapete, como se usa dizer? ${ }^{14}$

Serão, estas mortes, riscos a assumir em nome da necessidade de fazer justiça? Ou, um dia, passar-se-á a sentir como repulsiva a possibilidade de, dadas as circunstâncias em que tudo acontece, fora do quadro de vigilância regular em que decorre a vida colectiva, as prisões poderem ser palco, ainda que episódico e esporádico, de justiça feita pelas próprias mãos, praticada impunemente, com a cumplicidade objectiva de quem não promove a sistemática investigação, descoberta e publicitação dos factos apurados?

Não se pode generalizar, naturalmente. Mas não é possível que penas de morte extra-judiciais possam ser encomendadas para serem executadas dentro da prisão? Onde as vítimas não podem fugir ou defender-se. Esta hipótese colocada, num programa de opinião televisivo em Portugal, que tratava do suicídio nas prisões, gerou telefonemas emocionados de pessoas que disseram ter vivido e testemunhado o terror da

14 A resposta cabal a estas perguntas retóricas podem ser observadas pelos historiadores, quando revisitam as revoluções e podem questionar-se sobre o lugar e o sentido - pelo menos simbolicamente centrais - das libertações dos presos das cadeias, pelo menos desde a tomada da Bastilha. 
ameaças de morte a coberto das paredes prisionais, nomeadamente sob a forma de execução de terceiros. Estas situações serão raras e extremas? Provavelmente sim. Não estão é quantificadas. Nem explicadas. E, por isso, não se pode saber mais do que cada caso isolado que organizações denunciantes e órgãos de comunicação social, casuisticamente, e por vezes politicamente intimidados, fazem chegar à opinião pública, com efeitos imprevisíveis: a indiferença ou o escândalo, consoante a agenda mediática e o espírito popular na ocasião. ${ }^{15}$ Mas a capacidade de instigar o terror, coberto pelo segredo social, de o inscrever em estigmas auto-incorporados como se fossem segredos de Estado, com a cumplicidade tácita das populações, incluindo (ou principalmente?) aquelas estatisticamente mais vítimas de criminalização, torna a ideia comum de dissuasão do crime e uso legítimo da força do Estado contra o crime outra coisa do que aquela noção doutrinal e moralmente firme que geralmente se tem de reacção moral organizada da sociedade, através das instâncias institucionais próprias, aos comportamentos anti-sociais individualizados ou de pequenos grupos. De facto, toda a sociedade, todas as sociedades, cada um de nós, está, de uma forma ou de outra, necessariamente envolvido com um processo social muito complexo que é (mal) conhecido sob a designação de reforma penitenciária, umas vezes como actor de encobrimentos (cada um a seu nível), outras vezes como vítimas (geralmente apenas da cumplicidade indesejada ou da ignorância das perversidades que utilizam os meios prisionais para suas próprias finalidades particulares, mas por vezes como vítimas da violência directa, vitaliciamente traumatizante)

\section{O mundo e as prisões}

O sequestro é das práticas mais antigas da humanidade. Remete-nos para a própria possibilidade de reprodução biológica das sociedades humanas. O rapto de mulheres é uma actividade tão antiga que acontece ainda hoje estar ritualizado, em certas civilizações e classes sociais, como indispensável exercício romântico ante-nupcial. Remete-

15 Por exemplo, no Ocidente, nas festividades natalícias há falta de notícias, os controlos políticos da comunicação social estão menos organizados no terreno, por efeito das férias, e há melhor acolhimento popular a apelos públicos à compaixão. É boa altura para vingarem denúncias de casos de prisão. 
-nos também para as profundezas dos mistérios das sociabilidades em geral. Também a síndrome dos reféns, que os torna recorrentemente admiradores dos seus raptores e das suas perspectivas de luta, e aos observadores externos admirados com a reacção ao mesmo tempo tão regular e tão incompreensível dos sequestrados, revela-nos a nossa ignorância sobre o que sejam os laços de identificação social que produzem tais efeitos. Estes factos bem estabelecidos e conhecidos são contra-intuitivos porque a teoria social, ela própria, se deixa envolver por teias de preconceitos erróneos sobre a natureza humana. Todavia toma como certos e universais os preconceitos, em vez dos factos recorrentes, preferindo tornar excepção ou anormal aquilo que poderia revelar erros conceptuais de que não está disposta a abdicar. A teoria social participa, essa é a tese aqui defendida, e, portanto, reforça os segredos sociais que fundam o status quo sobre as políticas de violência, a que a sociologia se refere misteriosamente, parafraseando Max Weber, como o monopólio da violência legítima.

Observando qualquer sistema prisional, facilmente se comprovará haver uma aplicação significativamente diferenciada das penas de prisão consoante o sexo. E acontece de tal modo que ninguém se lembra de reclamar contra a discriminação que isso possa eventualmente representar. É para todos evidente que as penas de prisão são aplicadas mais aos homens que às mulheres. Mas ninguém explica racional e convincentemente tal evidência, de tão evidente. Porquê?

Outro fenómeno do mesmo género obscurece o processo de estigmatização, observado classicamente por Erwin Goffman. O estigma original era visível: na face ou nas mãos dos condenados, a quem eram subtraídos falanges, orelhas, narizes e outras partes do corpo, de modo a que todos os que com eles se encontrassem ficassem cientes de que se tratava de uma pessoa com tendências criminosos específicas. Nas sociedades modernas o estigma não é visível. É incorporado frequentemente pelo próprio acusado ou condenado, cuja tendência psicológica se auto-identificar com o perfil penalmente idealizado do tipo de criminoso capaz de concretizar as práticas de que tem de se defender, se for capaz. O estigma social não é apenas uma etiqueta: é também uma busca interior de quem seja socialmente condenado à procura de simpatia pela imagem social de si mesmo, tal e qual ela é produzida - tão intensamente - pelo próprio sistema judicial. Procura essa que o 
pode levar a procurar confirmar, em sociedade, a identidade que lhe é penalmente atribuída, mimando na prática o tipo-ideal definido pelas ciências criminais que lhe foram aplicadas. ${ }^{16}$

Numa prisão os presos - condenados ou não - parecem e comportam-se como criminosos, do mesmo modo que os sequestrados podem ser condicionados a mimar, uma vez libertados, os seus sequestradores. Isso mesmo nos deixou dito Foucault quando escreveu que os sistemas prisionais são indispensáveis à produção dos criminosos, tornando erudito o dito popular que considera a prisão universidade do crime. $\mathrm{O}$ mais extraordinário das prisões é que é possível, senão frequente, que as mesmas pessoas que entendem intuitivamente, e reproduzem de bom grado, frases populares deste tipo, sejam capazes de, eventualmente na mesma troca de palavras, comparar as penitenciárias a hotéis de cinco estrelas, a sorte dos desvalidos "pensionistas do Estado" a regimes liberais de cama, mesa e roupa lavada. Como se queixam as polícias e as magistraturas, a volubilidade da opinião pública a respeito de casos judiciais é imprevisível: tanto se reclama a libertação de presos como penas duras para quem não há provas acusatórias, consoante as ondas emocionais que se formam em sociedade.

Semelhantemente, também as teorias sociais se confundem perante os factos evidentes e não dão sinais de frustração por serem incapazes de produzir uma explicação, ainda que fosse controversa, sobre a discriminação sexual na aplicação de penas de prisão ou sobre a auto-reprodução dos estigmas sociais pelas suas próprias vítimas ou sobre a polarização das posições sociais face a certos casos de justiça por contraste ao alheamento mais vulgar. Ao contrário. Os investigadores sociais dão-se conta de (e resignam-se a) a necessidade de se identificarem, eles próprios, ora com as instâncias condenatórias e estigmatizantes ora com os/as criminalizados/as estigmatizados/as, importando eles próprios a polarização própria do campo em observação,

16 Este mecanismo de sociabilidade, o mimetismo de práticas de outros e de imagens socialmente difundidas, é vulgar, nas famílias, nos empregos, nos partidos políticos. Eventualmente não são tidos em suficiente conta nas nossas representações dominantes, a ter em consideração a surpresa com que os resultados de uma experiência como aquela que foi desenvolvida em Stanford foram recebidos pelos seus organizadores ( http://www.prisonexp.org/). Os estudantes divididos em reclusos e guardas cumpriram de tal maneira as suas obrigações que o fim da experiência foi antecipado, para evitar consequências negativas para os participantes, de tal maneira envolvidos com os respectivos papeis que a depressão e a violência ameaçavam tornarem-se crónicas. 
tornando-se difícil o convívio académico e a troca de argumentos entre pessoas relacionadas com o assunto em causa (CHRISTIE, 2000). ${ }^{17}$

\section{Segredos e naturezas sociais}

Em todos os países de mundo, virtualmente, existem os respectivos sistemas prisionais tutelados pela lei local. A ponto de se poder imaginar - sem razão - que todas as sociedades humanas se servem de prisões como forma de punição. Foucault causou admiração quando, no seu clássico Vigiar e Punir, fixou para as ciências sociais a ideia de que a prisão moderna, as penitenciárias que começaram a ser construídas no final do século XIX, eram resultado de um projecto técnico utilitaristas estudado e proposto por Bentham, sob a designação de Panopticon. Mas o mundo das prisões, nem por isso - apesar dos estudos históricos e antropológicos que confirmam a sua rápida evolução estrutural, tanto ao nível do direito (MORRIS; ROTHMAN, 1998) como das práticas sociais. (CUNHA, 2002) - deixou de ser representado, erradamente, como um mundo imutável e à parte da sociedade. Como um mundo tabu, uma espécie de inferno, uma inversão perversa do ideal de sociedade: violência quotidiana internalizada à força, sem recursos institucionais para instâncias de mediação judicial. As prisões são a experiência real, contingente, do fetiche negativo do ideal de sociedade a que aderimos à força. À força do Estado, actor autorizado para o exercício monopolista da força legítima, como explicou Max Weber. À força da sociedade, que deposita as suas esperanças na vida em família, apoiada pelos diversos serviços sociais (escola, sistema de saúde, polícia) e económicos (empregos, subsídios e seguros para enfrentar dificuldades extremas), para desfrutar das promessas da modernidade, como a liberdade, a igualdade, a mobilidade, as férias, a informação, o entretenimento.

Quando as coisas não correm de feição para a sociedade, ou para o Estado, é previsível que se sinta a necessidade de organizar a resistência (social e política) para evitar ir atrás de mudanças impostas

17 Este autor refere que, para a Noruega, uma das actividades chave para ser possível a redução da aplicação das penas de prisão e a opção por regimes abertos que caracterizam o actual sistema norueguês foi a imersão, uma vez por ano, que reunia, durante um longo fim-de-semana, magistrados e guardas prisionais, polícias e familiares de presos, advogados e jornalistas, políticos e presidiários, académicos e directores de cadeia, médicos e gestores, bem como todos os grupos interessados em assuntos prisionais. 
por eventos singulares ou atitudes minoritárias ou externas. Tal como provavelmente desde sempre aconteceu aos humanos. Modernamente, há que encontrar formas de produzir explicações (históricas, políticas, sociais) que confirmem à sociedade e ao Estado que ambos, ou pelo menos este último, por delegação, estão/está em controlo da situação e capaz de continuar a garantir estabilidade e segurança susceptíveis de suportarem a credibilidade dos exercícios de planeamento no quadro de uma divisão de trabalho que transfere as recompensas para o futuro, no tempo da distribuição, posterior ao da produção.

Trata-se de um correlato social do mesmo fenómeno que transforma o sequestrado num simpatizante da causa do sequestrador, o condenado em mimo do tipo de criminoso que lhe é descrito pelos magistrados, a criança simulacro dos seus pais, o discípulo uma réplica do mestre. Em situações de maior tensão, a tendência dos seres humanos em assumirem para si a convicção de adesão emocional ao paradigma simbólico dominante - o espírito de submissão - parece extremar-se e exigir formas expressivas desse compromisso. Desse modo se maximizam socialmente as hipóteses de sucesso dos empreendimentos em que todos, superiores e subordinados, estão desigualmente envolvidos.

Para quem esteja de fora, descomprometido com as trocas emocionais em curso, pode parecer estranho, desumano, irracional. Aquilo que parece estranho ao observador externo é naturalizado por quem viva por dentro, solidariamente, as relações sociais em análise. Se assim é, não será que tal tendência também afecta o observador, incrédulo quando se coloca de fora das relações sociais, mas menos capaz de analisar o que se passa nas redes sociais de que se sente parte integrante?

Na guerra, na transição para a vida adulta, a propósito de uma aliança social entre famílias ou clãs, sempre que muda de estação do ano, todos os povos organizam rituais regidos por mitos de controlo sobre a natureza e as próprias sociedades, a que chamamos religião, que exigem e exibem a violência ritualizada, simbólica e corporal, eventualmente a guerra. Esta violência legítima, que procura controlar outros tipos de violência, é uma violência mágica, como a dança da chuva ou a guerra que se justifica em nome de tornar mais difícil a violência em sociedade (ou a tortura para descobrir a verdade). Nos outros povos e culturas as violências parecem-nos repugnantes. Mas dentro dos nossos contextos existências quotidianos nem pensamos 
na violência que está envolvida: tome-se o caso das touradas, que impressionam os amigos dos animais e que deixam os aficionados estarrecidos de incompreensão pela falta de respeito alheia pela expressão pública e popular da nobreza dos toiros. Ou tome-se o caso dos alimentos, como os porcos ou as cobras ou os macacos ou as formigas voadoras ou os cães, face ao que as diferentes culturas produzem saberes, gostos e repugnâncias que se incorporam socialmente em cada indivíduo. Tome-se o exemplo das guerras, das fomes, das lutas às epidemias. Vê-las na televisão traz-nos inconscientemente à consciência a pergunta desresponsabilizadora: não serão as vítimas culpadas do que lhes aconteceu, por que não se preveniram o suficiente? O pudor que alguns de nós sentimos e que nos faz reprimir, pela razão, estas inquietações, noutras pessoas não existe. Há mesmo quem elabore sobre a xenofobia natural, organizando o racismo. Tal falta de pudor pode mesmo ser levada ao extremo, em certas circunstâncias, de serem seres humanos a utilizarem as dificuldades alheias para explorar quem sejam as vítimas - por exemplo, tomando para si ajuda humanitária 50 para terceiros ou organizando limpezas étnicas e genocídios. Sim, também na Europa e recentemente tais casos se deram.

Não é humanamente possível viver com a responsabilidade de cuidar solidariamente dos desvalidos. Em toda a parte do mundo, mas especialmente nas cidades, as pessoas obrigam-se a delimitar mais ou menos as suas disponibilidades de actuar em solidariedade perante a urgência de vidas em competição entre si. Não é possível distribuir por todos os pobres alguma esmola sem nos acontecer como a S. Francisco de Assis. Portanto, comedimo-nos. E - este é o nosso ponto - não prestamos atenção. Não temos a capacidade - provavelmente ainda bem - de prestar atenção a não ser a um conjunto bem limitado de questões e problemas sobre os quais nos dispomos a agir intencionalmente: as questões profissionais e familiares, a gestão de alguns amigos e dos tempos livres e pouco mais. Ainda assim os especialistas sempre nos recordam que estamos a esquecer de organizar melhor o tempo de trabalho, a comunicação com a família, a inteligência emocional com os amigos, as férias com melhor relação preço-qualidade, etc.

A verdade é que os segredos sociais são-nos tão indispensáveis como os hábitos sociais. Sem eles não seria possível concentrarmos as nossas atenções e intenções em objectivos limitados mas consequentes, 
com repercussões sociais a que os sociólogos chamam agências. Os segredos sociais estão para as estruturas sociais como a matéria invisível recentemente descoberta como sendo o esqueleto do universo está para o cosmos. A violência humana está para os Estados como a vida quotidiana está para as instituições, como a existência está para aquilo que é reconhecido e imaginado como realidade ou como a natureza está para as suas expressões acessíveis à nossa volúvel (má?) consciência.

\section{Referências}

BUTTERFIELD, Fox. Mistreatment of Prisoners Is Called Routine in U.S, NY TIMES, 8 maio 2004.

CASTELS, Manuel. A Galáxia Internet - Reflexões sobre a internet, negócios e sociedade. Lisboa: FCG, 2004.

CHRISTIE, Nils. Crime Control as Industry - Towards Gulags, Western Style. 3. Ed.. London: Routledge: Routledge, 2000.

CUNHA, Manuela Ivone. Entre o bairro e a prisão: tráficos e trajectos, Fim de Século, 2002.

FELLNER, Jamie. US Addiction to Incarceration Puts 2.3 Million in Prison. Human Rights Watch, dec. 2007. Disponível em: <http://www.hrw.org/ news/2006/11/30/us-addiction-incarceration-puts-23-million-prison>. Acesso em: 14 fev. 2007.

FOUCAULT, Michel. Vigiar e punir - História da violência nas prisões. 20. ed. Petrópolis: Vozes, 1999.

GERARD, Vanessa. U.S. Prison Population Approaches 1.5 Million. Corrections Today, v. 67, n. 1 feb. 2005. Disponível em: < http://crime. about.com/od/prison/a/blbjs041107.htm>. Acesso em: 14 fev. 2007. JAKOBS, Günther; MELIÁ, Manuel Cancio. Derecho Penal del Enemigo. Madrid: Cuadernos Civitas, 2003.

JEAVANS, Christine. Dead after less than a day in prison. BBC News, 6 abr. 2006. Disponível em: <http://news.bbc.co.uk/1/hi/uk/4814928.stm> Acesso em: 3 ago. 2010.

KLAHR, Marco Lara. Hoy te toca la muerte, México: Planeta, 2006.

MORRIS, Norval, e David J. Rothman.The Oxford History of the Prison The Practice of Punishment in Western Society, Oxford: Oxford University Press, 1998. 
PERKINSON, Robert. Some US prisons as bad as Abu Ghraib [mensagem pessoal] Mensagem recebida por < perk@hawaii.edu> em 21 jul. 2006.

SPACE 1 - COUNCIL OF EUROPE ANNUAL PENAL STATISTICS. Deaths in penal institutions, 2010. Disponível em: <http://www3.unil.ch/wpmu/ space/space-i/>. Acesso em: 3 ago. 2010

WALMSLAY, Roy (Ed.). World Prison Population List. Disponível em:

<http://aic.gov.au/stats/other/wpl.html>, Acesso em: 3 ago. 2010.

WIKIPEDIA, THE FREE ENCYCLOPEDIA. Disponível em: <http:// en.wikipedia.org/wiki/Prison\#Prisons_by_country >. Acesso em: $14 \mathrm{fev}$. 2007.

WOODIWISS, Michael. Gangster Capitalism: The United States and the Global Rise of Organized Crime. Londres: Constable, 2005.

WOODIWISS, Michael. Crime, Crusades and Corruption - Prohibitions in the United States, 1900-1987, London: Piter Publisher, 1988. 


\section{Terceirização de prisões: notas de uma análise comparada}

Sandro Cabral

Paulo Furquim de Azevedo

\section{Introdução}

Privatizações, concessões, terceirizações e Parcerias Público-Privada (PPP) são algumas das alternativas utilizadas pelos governos para a delegação de atividades anteriormente viabilizadas por agentes públicos, tais como: eletricidade, telecomunicações, água e saneamento, estradas, ferrovias e, mais recentemente, prisões.

A participação privada na gestão e operação de prisões ganhou notoriedade a partir da experiência estadunidense na década de 1980. Essa iniciativa inspirou movimentos semelhantes em países como Inglaterra, França, Austrália, África do Sul e Brasil, que passaram a utilizar a participação de entes privados como resposta ao aumento da população carcerária e de seus custos, à deterioração das condições de encarceramento e às pressões sociais para o endurecimento das penas.

No Brasil, a atuação de empresas privadas na operação de estabelecimentos penais tem início em 1999, no Estado do Paraná. No final de 2009, 11 unidades se encontravam sob operação de empresas privadas no país. Entretanto, pouco se sabe sobre o desempenho das prisões 
operadas dentro desta modalidade alternativa de gestão no país. ${ }^{1}$ No presente capítulo compara-se duas prisões similares, localizadas no Estado da Bahia e que comungam o mesmo projeto arquitetônico, diferindo, entretanto, pela estrutura de governança empregada: uma sob gestão pública tradicional e outra terceirizada.

A escolha por unidades com os mesmos padrões de semelhança em termos de capacidade, perfil criminológico dos internos e localização (ambas no interior do Estado) visa controlar as variáveis que podem afetar o desempenho, na medida em que ambas estão submetidas ao mesmo conjunto de regulamentos formais e informais, caracterizando o presente estudo como um quase-experimento. Deste modo, os resultados observados refletem as decisões tomadas pelos atores envolvidos na gestão e operação de cada unidade, as quais são condicionadas pelas estruturas de incentivos propiciadas e pela habilidade apresentada por cada estrutura de governança para contornar as restrições institucionais existentes. As diferenças observadas entre as duas formas de provisão, pública e privada, são analisadas por meio dos instrumentais teóricos agrupados sob a Nova Economia Institucional (NORTH, 1990; WILLIAMSON, 1996; SHIRLEY; MÉNARD, 2002; MÉNARD, 2004) e sob a abordagem de contratos incompletos. (HART; SHLEIFER; VISHNY, 1997; HART, 2003)

A próxima seção discute como alguns tópicos da literatura econômica e administrativa podem ser úteis à compreensão do debate "público versus privado" no setor prisional. Em seguida, são apresentadas as diversas modalidades de intervenção de atores privados em estabelecimentos penais, com foco para os diferentes arranjos contratuais possíveis. A quarta seção, além de abordar algumas peculiaridades do setor prisional no país, traz também as evidências empíricas, ao passo que a quinta é dedicada à explicação das prováveis razões para as diferenças encontradas. As conclusões ficam reservadas para a última parte do trabalho.

1 O desempenho público versus privado sob as óticas administrativa e econômica foi observado no Brasil em poucos trabalhos. Ver Cabral (2006, 2007); Cabral e Azevedo (2008); Cabral e outros $(2010,2012)$. Há outros estudos sobre o tema nas áreas de Direito (D’URSO, 1996; VIGGIANO, 2002; AFFONSO, 2002), Filosofia (MINHOTO, 2000) e Sociologia.(WACQUANT, 2001) 


\section{O dilema "público versus privado": uma síntese a partir da literatura de administração e economia}

Em uma perspectiva econômica, prisões podem ser classificadas como bens públicos puros, uma vez que as externalidades geradas são coletivas e as possibilidades de exclusão de indivíduos que não contribuem para a manutenção do serviço são quase inexistentes. (OSTROM; OSTROM, 1977) Entretanto, a variedade das experiências prisionais, nos mais diferentes contextos históricos, apontam para um desenho organizacional mais complexo do que aquele derivado puramente da teoria de bens públicos. (D’AMICO, 2009) Entre os elementos que devem ser considerados estão a presença de ativos específicos e não-reempregáveis (WILLIAMSON, 1996) e o fato de o número de beneficiários do serviço ser, normalmente, superior ao eleitorado da região (LEVY; SPILLER, 1994), ambos elementos relevantes para o desempenho de diferentes estruturas de governança no sistema prisional.

Da mesma forma que em outras utilidades públicas, no setor

prisional as instituições formais e informais podem influenciar nos resultados observados. Sob o ponto de vista formal, quatro conjuntos de instituições são relevantes: instituições reguladoras, judiciais, políticas e externas. (SHIRLEY; MÉNARD, 2002) Além disso, o papel das instituições informais no setor prisional não pode ser ignorado. Nesta seara se incluem as regras estabelecidas pelos próprios internos e os arranjos ilícitos entre funcionários do estabelecimento e prisioneiros. Em função da existência desses fatores, esquemas de monitoramento e incentivos são extremamente importantes no setor prisional, seja sob a gestão pública ou sob a gestão com empresas privadas. Desta forma, três componentes utilizados no desenho de estruturas de governança para serviços de utilidade pública podem ser perfeitamente aplicados ao setor prisional: a) assimetria de informações; b) estruturas de recompensas e punições; c) mecanismos de compromisso confiável entre as partes. (SHIRLEY; MÉNARD, 2002) Estes três elementos moldam as estruturas de incentivos dos atores envolvidos na provisão do serviço.

Geralmente, os governos são os provedores dos serviços prisionais, o que implica na estrutura de governança pública. Williamson (1999) identifica algumas diferenças entre as modalidades pública e 
privada de gestão. Os atributos principais das formas privadas estariam ligados à intensidade dos incentivos, aos menores níveis de controles administrativos e ao uso do judiciário para resolução de eventuais conflitos. Sob a governança pública, por outro lado, os incentivos seriam menores, os controles mais rígidos e a própria organização atua como instância de solução de conflitos.

Na próxima seção, são apresentados alguns trabalhos produzidos sob as óticas econômicas e gerenciais, relacionados ao dilema público versus privado em prisões.

\section{Prisões públicas e operadas por empresas privadas: contribuições da literatura de \\ Administração e Economia}

Embora haja algumas referências na literatura que comparam o desempenho entre as modalidades pública e privada de gestão e operação de prisões, os resultados obtidos não são conclusivos.

Hart, Shleifer e Vishny (1997), ao modelarem a questão sob o ponto de vista teórico, concluem que haverá redução de custos em detrimento da qualidade em prisões privatizadas em comparação com prisões públicas, em função da dificuldade de definir contratualmente e avaliar alguns aspectos da qualidade desses serviços. Na mesma linha, Williamson (1999) sinaliza que a delegação da gestão e operação de prisões a atores privados deve ser vista com cautela em função da presença de ativos de alta especificidade e, mais importante, por conta da necessidade de aspectos relacionados à probidade e lealdade aos princípios governamentais. Bayer e Pozen (2005), ao analisarem o caso dos estabelecimentos destinados a menores infratores na Flórida, por meio de um extensivo teste econométrico, confirmam as hipóteses de Hart, Shleifer e Vishny (1997). Por outro lado, há autores que concluem pela superioridade das formas privadas de gestão. (ARCHEOEMBEAULT; DEIS, 1996; MITCHELL, 2003; BLUSTEIN; COHEN, 2003; GUPPY, 2003)

Os trabalhos acima, no entanto, não analisam as estruturas híbridas de governança. De fato, entre as duas modalidades polares de provisão - gestão pública tradicional e privatização total do estabelecimento penal - há uma miríade de possibilidades (concessões, terceirizações, PPP para construção e operação, contratos de gestão 
junto a organizações do terceiro setor, dentre outras). Nestes diversos arranjos contratuais, os governos podem delegar um número superior ou inferior de atividades aos operadores privados. Com isto, os termos e as estruturas de incentivos estabelecidas podem variar significativamente, assim como, por consequência, os resultados observados. O caso brasileiro enquadra-se nessa categoria, na medida em que possui a modalidade de terceirização e de PPP, conforme desenvolvido a seguir.

\section{Modelos de governança privada em prisões}

Basicamente, podem ser identificados dois grandes modelos de participação privada na gestão e operação de prisões: o modelo estadunidense e o modelo francês. (ARAÚJO, 1995)

No primeiro, naturalmente de acordo com as leis de cada Estado, os operadores privados podem se envolver com todas as dimensões do serviço prisional, da construção de novas unidades à operação e gerenciamento total, o que inclui a parte de hotelaria, assistência aos internos e atividades de segurança. Em 2009, cerca de 7\% da população carcerária americana estava abrigada em prisões geridas por operadores privados. (US DEPARTMENT OF JUSTICE, 2009) Em geral os operadores privados cobram dos governos (seus clientes finais) uma taxa diária por cada interno. Desta forma, o desempenho financeiro é dependente do número da taxa de "homens-dia", o que cria fortes incentivos para a manutenção destas prisões à plena capacidade. (MORRIS, 2007)

Em contraste, no modelo francês o governo permanece como responsável pelas atividades de direção, vigilância interna e externa, controle de fluxo de presos (greffe) e, se for o caso, punição dos internos. Combina-se, assim, a atuação de funcionários públicos e da empresa privada na mesma unidade, sob o comando dos primeiros. Os contratos firmados junto a agentes privados para construção e operação são separados, ou na expressão proposta por Hart (2003): unbundled. O operador privado fica encarregado do suprimento da parte de hotelaria (alimentação, vestuário, limpeza, etc.) e por atividades ligadas à reinserção do indivíduo, tais como: gestão dos canteiros de trabalho, educação básica e profissionalizante. A experiência francesa foi iniciada em 1990 em resposta ao aumento da população prisional. Desde então, todas as novas vagas foram construídas e operadas por empresas 
privadas, perfazendo um total de 17.000. De acordo com a Direction de l'Administration Pénitentiaire (2005), há na França 27 prisões sob esta forma alternativa de provisão. Contudo, 80\% dos funcionários nestas prisões são funcionários públicos. (LAZERGES, 1997)

No Brasil, a primeira experiência de participação privada teve inicio em 1999, no Estado do Paraná, na Penitenciaria Industrial de Guarapuava (PIG), dentro da modalidade de terceirização de serviços, seguindo as linhas mestras do modelo francês. Aqui, porém, as atividades de vigilância interna, executadas por agentes de disciplina podem ser delegadas a operadores privados, de modo que, em relação à França, a participação privada no interior do estabelecimento é mais abrangente. No final de 2009, 11 unidades se encontravam sob operação de empresas privadas nos Estados do Amazonas (3), Bahia (5), Espírito Santo (2), Santa Catarina (1), abrigando cerca de 1\% da população carcerária total do país. ${ }^{2}$

No Brasil, todos os contratos assinados entre operadores privados e autoridades públicas são bastante similares. O governo é responsável pela licitação para a construção da prisão e, durante ou após o final da obra, por promover outra licitação para concessão dos serviços de operação da prisão. Cabe ao operador privado a provisão de todos os serviços necessários à operação da unidade, o que inclui alimentação, limpeza, serviços de saúde, educação, atividades laborais e supervisão dos internos. Por conta de restrições legais, o governo permanece responsável pelas atividades de direção e coordenação de segurança da unidade. A vigilância externa permanece sob responsabilidade da Polícia Militar, de forma a conservar com o governo a prerrogativa de uso legítimo da força. Seguindo o exemplo da França, há dois contratos separados para as atividades de construção e operação de presídios. Os governos de Minas Gerais e Pernambuco, por sua vez, optaram por um modelo de PPP, com previsão de início em 2011, em que construção e operação estão em um único contrato.

Como consequência, no caso brasileiro, quando se compara as estruturas pública e privada de governança, realiza-se a comparação entre hierarquia (provisão pública) e formas híbridas (arranjos contratuais entre governos e operadores privados).

2 A experiência pioneira do estado do Paraná na participação privada em serviços prisionais foi interrompida pelo Governo do Estado em 2006. 


\section{Terceirização de prisões: o caso baiano}

Nesta seção, são apresentadas as evidências empíricas da participação de atores privados na gestão de prisões. Primeiramente, são apresentadas as características do ambiente institucional que afetam o setor prisional, uma vez que tais fatores são fundamentais à avaliação dos diferentes modos de governança e para o desenho de políticas públicas. Em seguida, demonstram-se as estruturas metodológicas adotadas na análise comparativa discreta empreendida, para posteriormente se apresentar os dados empíricos coletados.

\section{Regras formais e organizações}

O setor prisional, no Brasil, é regulado pela Lei de Execuções Penais (Lei 7210.84), a qual atribui aos Estados membros da federação a responsabilidade pela custódia dos internos. Os estabelecimentos penais teriam, desta forma, os seguintes papéis: punir os transgressores do ordenamento jurídico vigente, proteger a sociedade de novos crimes e prover as condições necessárias à reinserção do indivíduo ao convívio social. Em adição às diversas organizações encarregadas pelas atividades penais em cada Estado, há outras envolvidas no processo de custódia, tais como o Departamento Penitenciário Nacional (DEPEN) e os conselhos de política criminal e penitenciária, ambos com funções consultivas e regulatórias. Entre as instituições judiciárias envolvidas encontram-se os tribunais, juízes, promotores e defensores públicos. Cabe ao juiz de execução penal determinar onde o sentenciado será custodiado. Normalmente, os internos são alocados em estabelecimentos próximos ao seu núcleo familiar, como forma de facilitar a futura reinserção. (CABRAL, 2006)

O setor prisional também é sujeito à pressão de organizações políticas, tais como câmaras de deputados e assembleias legislativas, que representam interesses dos mais diversos matizes, dos advogados do endurecimento das penas e das soluções pró-cárcere aos defensores dos direitos humanos e da implementação de penas alternativas. Diversas organizações externas ao sistema prisional vêm condicionando as ações dos gestores do setor. Dentre estas se destacam as Organizações Não Governamentais (ONG) ligadas à defesa dos direitos humanos e as organizações religiosas. Os agrupamentos religiosos que emergem 
dentro dos estabelecimentos penais ocupam papel fundamental na mitigação dos problemas no interior das prisões. Para os internos as organizações religiosas podem estabelecer alguma ordem no caos de suas vidas pessoais (VARELLA, 1999, p. 117), gerando, por consequência, benefícios para a administração, no que tange à possibilidade da manutenção da ordem interna.

\section{Regras Informais}

A organização social intramuros e as normas sociais estabelecidas pelos internos são fatores de conhecimento público. A emergência e a cristalização das regras informais são associadas aos códigos de conduta inerentes às atividades criminais e às restrições formais impostas. Entre estas se destacam o afastamento do convívio social e a supressão do amparo formal às trocas entre presidiários, o que inclui a proibição do uso de moeda e, de modo mais geral, o banimento formal de direitos de propriedade privados.

Há uma clara hierarquia social interna, baseada, sobretudo, na capacidade e responsabilidade de enforcement das normas sociais dos presidiários. O afastamento do convívio social é a principal motivação para dois códigos de conduta: normas de convivência nas celas e respeito às visitas. Em função das celas das prisões serem espaços limitados, a proximidade e o contato entre os ocupantes são inevitáveis, exigindo algumas regras básicas para a mitigação dos custos decorrentes do relacionamento entre os indivíduos. Outro comportamento tacitamente prescrito pelos internos é o respeito pelos dias de visita e aos familiares dos demais. Preservar a tranquilidade nestes dias, evitando-se agressões, acertos de contas ou outras situações constrangedoras é essencial para não afugentar os visitantes. Naturalmente, punições são aplicadas àqueles que não respeitam estas regras.

A vigilância e a atuação dos gestores prisionais são essenciais para evitar ou mitigar a emergência de lideranças nocivas à manutenção da ordem na unidade, fazendo com que, muitas vezes, a condução das atividades se dê nos limites da ética e da legalidade. Com efeito, frequentemente são utilizadas estruturas de informantes recrutados entre os próprios internos. ${ }^{3}$ Além do uso de informantes, a gestão do presídio

3 As principais informações fornecidas estão relacionadas às articulações urdidas pelos internos para tentar viabilizar fugas e rebeliões, dados relativos às disputas internas, às relações de 
dialoga com representantes dos presos sobre assuntos diversos que afetam decisões operacionais do presídio, como alimentação, alocação de presos em celas e pavilhões, entre outros. Nesse caso, o conhecimento do ordenamento social dos presos é um fator fundamental à gestão, uma vez que revela a representatividade desses interlocutores e as possíveis consequências - como rebeliões e assassinatos - do conflito entre as rotinas gerenciais e as normas sociais dos presidiários.

É neste meio particular, em que as normas sociais dos internos afetam o desempenho do serviço prisional, que as governanças pública e privada são comparadas. Uma síntese dos principais resultados é apresentada na próxima seção.

\section{Estudos de caso e métodos de investigação}

O presente estudo executa uma análise comparativa entre dois estabelecimentos penais de idêntico tamanho (capacidade para 268 internos) e mesmo projeto arquitetônico: Conjunto Penal de Teixeira de Freitas (CPTF) regido pela governança pública tradicional - e Conjunto Penal de Valença (CPV) - operado na modalidade de terceirização de serviços ${ }^{4}$. Ambas as unidades são de segurança máxima e estão localizadas no interior do Estado da Bahia. Os internos dos dois estabelecimentos possuem os mesmos perfis criminológicos. ${ }^{5}$

Na mesma linha do trabalho de Archeoembeault e Deis (1996), busca-se aqui comparar unidades penais de características similares e localizadas em um mesmo Estado da federação, como forma de identificar os efeitos das modalidades de governança, privada e pública, controlando-se as questões regionais e as características físicas do

débito e crédito entre os internos e de relações de pessoas que estão agindo como "mulas" (pessoas que fazem o transporte de drogas, armas e outras substâncias proibidas para a parte interna da prisão).

4 O contrato celebrado entre governo e operadora possui uma duração de cinco anos e inclui o suprimento de todos os serviços necessários à operação da unidade: alimentação, vigilância interna, assistência médica e jurídica, atividades de recreação. A operadora privada é responsável pelo pagamento das despesas de água, eletricidade e telefonia. Além dos policiais militares lotados nas partes periféricas da unidade, há somente três funcionários públicos trabalhando diretamente no estabelecimento: diretor, vice-diretor e chefe de segurança.

5 As unidades foram inauguradas em 2001 (CPTF) e em janeiro de 2003 (CPV). Em ambas as prisões, ao redor de $60 \%$ dos internos possuem penas menores que 8 anos de prisão. A maior deles possui condenação por crimes contra a pessoa (homicídios, agressões,etc), seguido de perto por crimes contra o patrimônio (roubos e furtos) e por crimes ligados ao tráfico de drogas. Entretanto, há uma diferença significativa, quando se observam os índices de reincidência, pois enquanto o CPTF abriga apenas 5\%, o CPV possui 30\% de presos com este perfil. 
presídio. A escolha de dois casos no mesmo Estado também contribui para o controle do efeito das variáveis institucionais, uma vez que no Brasil, em função de suas proporções geográficas e de sua própria diversidade cultural, as regras formais e informais podem variar significativamente.

Os dados utilizados cobrem os anos de 2003 e 2004 e foram obtidos junto à Superintendência de Assuntos Penais (SAP) da Secretaria de Justiça e Direitos Humanos do Governo do Estado da Bahia (SJDH-BA). Foram disponibilizadas informações estatísticas, contratos e os estatutos internos das unidades. A estes se somam informações qualitativas colhidas por meio de 18 entrevistas semiestruturadas aplicadas junto aos gestores das unidades e a outros atores que possuam algum tipo de influência sobre os estabelecimentos penais analisados, como por exemplo, representantes da defensoria pública, de instituições reguladoras, políticas, judiciais e sindicais. Tentamos coletar dados relativos a períodos ulteriores, mas sem êxito por conta da ausência de colaboração da administração penitenciária do Estado da Bahia.

O método de investigação se inspira em Shirley e Ménard (2002) e combina análises quantitativas e qualitativas, com a finalidade de compreender os papéis dos (as): a) fatores de incentivo (assimetria de informações, recompensas e punições e mecanismos de compromisso confiável); b) instituições formais e informais; e, c) rotinas gerenciais no desempenho de cada unidade.

No CPTF, em concordância com as leis brasileiras, os empregados, aprovados mediante concurso, gozam de estabilidade no emprego e não podem ser demitidos, a não ser depois de constatada alguma falta grave. O processo de desligamento é moroso e muito raramente culmina em demissão. Por sua vez, os empregados da operadora do CPV estavam, à época da pesquisa, submetidos à Consolidação das Leis de Trabalho (CLT).

\section{Alguns resultados empíricos}

Os indicadores de desempenho das duas unidades são comparados em três dimensões: administrativa, segurança e serviços propiciados aos internos. Embora as unidades sejam similares, é possível encontrar diferenças expressivas de desempenho. 
Primeiro, em relação aos indicadores administrativos, tem-se que a prisão pública emprega $20 \%$ a mais de funcionários e reporta taxas de absenteísmo três vezes mais altas que a prisão terceirizada. Entretanto, os salários dos agentes penitenciários no CPV são 60\% inferiores em relação aos seus colegas do CPTF. Enquanto dois empregados foram demitidos na prisão pública, no mesmo período, na prisão operada pela empresa privada, 15 pessoas foram demitidas. O CPTF gasta três vezes mais com despesas de água e eletricidade e investiu 50\% menos em manutenção da unidade, em relação ao CPV nos anos de 2003 e 2004. As despesas com salários e com água e eletricidade perfazem algo em torno de $60 \%$ do custo direto de operação.

Segundo, os indicadores de segurança e ordem os resultados também diferem substancialmente. No período analisado nenhuma fuga ou tentativa de fuga foi registrada no CPV, ao passo que, na prisão pública, os números foram respectivamente de oito e 25. Uma rebelião ocorreu no estabelecimento operado pela empresa privada. As despesas relativas a este evento (ao redor de US\$15.000) foram absorvidas pela operadora. O ambiente interno do CPTF é mais violento que o do CPV, uma vez que foram registradas oito agressões de internos contra empregados, ao passo que em Valença nenhuma ocorrência foi registrada. No mesmo período, o número de agressões entre os próprios internos foi 12 vezes maior na prisão pública. ${ }^{6}$

Terceiro, no que se refere aos indicadores de serviços oferecidos aos internos, tem-se que a prisão operada pela empresa privada apresenta indicadores de desempenho superiores, em quesitos como assistência médica (10 vezes maior) e assistência psicológica. A prisão pública, no entanto, apresentou um número ligeiramente superior de consultas odontológicas (ao redor de 8\%). O número de atendimentos jurídicos no CPV é 20 vezes maior em relação ao CPTF, o que decorre do modo como a governança privada lida com a ineficiência do sistema jurisdicional local, ponto este desenvolvido em maior detalhe na próxima seção. Vale lembrar que a falta de assistência jurídica é uma das principais causas de eventos indesejados no interior das prisões.

6 Nenhuma ocorrência de estupro foi registrada nas duas unidades. As autoridades entrevistadas, no entanto, suspeitam que estes eventos podem acontecer no interior das células, embora dificilmente sejam relatados pelos internos às autoridades, em função dos códigos de conduta dos prisioneiros. 
Em suma, os indicadores de desempenho revelam que a estrutura privada de governança apresenta resultados superiores em termos administrativos, de ordem e segurança e serviços prestados aos internos.

\section{Por que as diferenças ocorrem? Algumas possíveis razões}

A comparação entre os casos de governança pública e privada indica algumas características importantes decorrentes da complexa estrutura de incentivos e monitoramento que permeia o sistema prisional.

A primeira razão está relacionada aos instrumentos disponíveis na governança privada para a redução dos efeitos adversos da assimetria de informações. Seja trabalhando em prisões públicas ou terceirizadas, os agentes de disciplina (maior contingente de funcionários das prisões) estão propensos a esconder de seus superiores informações relativas aos eventuais esquemas de corrupção e ao uso da violência contra os internos. O contrato assinado entre governo e operador

64 privado prevê mecanismos de monitoramento por parte do Estado e ameaças críveis em termos de punição que permitem a redução dos efeitos da informação assimétrica. ${ }^{7}$ Além disso, a separação entre operação e gestão facilita a efetivação de sanções na ocorrência de falhas contratuais, afetando, nos termos propostos por Brickley e outros (1997), tanto a redução da informação assimétrica entre governo e empresa privada, quanto os incentivos providos ao operador. Por exemplo, o diretor da unidade (representante do Estado) pode não autorizar o pagamento da fatura de prestação de serviços, causando problemas no fluxo de caixa da operadora, criando, desta forma, incentivos para o cumprimento contratual.

A segunda razão está relacionada aos diferentes incentivos para lidar com as ineficiências do sistema legal. O contrato assinado entre operadora e governo prevê a custódia de 268 internos, mediante o recebimento de um valor fixo independentemente do número de internos presentes na unidade. Desse modo, as margens de lucro do

7 Um exemplo adicional de redução da informação assimétrica é relacionado ao fato de o operador privado ser obrigado a enviar ao governo estadual cópias de todos os pagamentos efetuados e das guias de recolhimento de impostos e contribuições sociais. Tais informações além de, em tese, protegerem o interesse público propiciam também a estimação do custo real de operação da unidade delegada à empresa privada, o que pode ser bastante útil para o estabelecimento de limites de preços em licitações futuras. 
operador privado aumentam à medida que o número de internos sob sua responsabilidade diminui. Tal fato faz com que os ganhos do operador privado sejam muito sensíveis à eficiência de assuntos legais relacionados a pedidos para liberdade condicional e relaxamento de prisão. Sendo assim, há um forte incentivo ao operador privado para utilizar os meios disponíveis que tornem os processos dos presidiários mais céleres.

Adicionalmente, os custos associados a rebeliões podem ser repassados ao operador privado, o que reforça o interesse do operador privado na eficiência do setor judiciário, à medida que tal fator pode mitigar os conflitos internos. ${ }^{8}$ A superpopulação constitui um ponto de preocupação para os gestores prisionais, para a qual são poucas as ações que podem ser tomadas. Para a empresa privada, a preocupação é ainda maior, pois suas margens estão em jogo quando o fluxo de mandados expedidos pelos juízes de execução penal é maior que a capacidade de absorção da prisão ${ }^{9}$.

Em resposta a estes incentivos, o operador privado contrata advogados para o atendimento jurídico dos presos, em contraposição à governança pública, que faz uso de defensores públicos no caso de internos que não podem arcar com os custos de sua defesa. À época da realização das entrevistas de campo, os advogados contratados pelo operador privado recebiam bônus equivalentes a 3\% do salário mensal, para cada alvará de soltura concedido. Como resultado, o CPV apresenta maiores índices de consultas jurídicas em relação ao CPTF. Essa disparidade se deve também à falta de defensores públicos para atender as demandas da prisão pública. À época da pesquisa, havia apenas um defensor para toda a cidade de Teixeira de Freitas (atualmente com 120 mil habitantes). Como forma de contornar as restrições relacionadas à lentidão das cortes, a operadora do CPV contratou três assistentes administrativos para auxiliar as atividades operacionais da comarca que atende a unidade. Tal medida apresentou um forte impacto na agilidade de apreciação dos casos dos internos da unidade, o que é crucial para pacificar o ambiente interno à prisão. A prisão pública,

8 Como forma de diminuir os conflitos internos é necessário também entender o que se sucede no interior das celas e das galerias. Decorre daí a importância da compreensão das normas informais. Neste caso, estruturas de informantes podem ser invocadas.

9 No final de setembro de 2005 havia no CPV 311 internos, ou seja, 43 acima da capacidade. 
por sua vez, possui poucas chances de contornar as restrições do setor judiciário que impactam em seu cotidiano. O efeito observado que pode ser associado a essa estrutura de incentivos distinta é a redução de conflitos e aumento do atendimento jurídico. É possível que a mesma estrutura de incentivos tenha efeitos perversos sobre o comportamento do judiciário, em termos de equidade no tratamento de presos e de viés nas decisões no sentido da liberação dos presos. Contudo, não foram observadas, no estudo de caso, quaisquer evidências nessa direção.

A terceira razão está relacionada aos mecanismos de monitoramento e recompensas. Os incentivos que a governança privada provê para a redução de rebeliões e conflitos internos também se manifestam nos esforços de monitoramento. Conforme relato de um diretor da empresa contratada: “[...] o governo ao contratar quer se ver livre dos problemas. Minha missão é me antecipar aos problemas e caso eles ocorram resolvê-los antes que cheguem ao conhecimento do contratante".

Com a anuência do governo, a operadora investiu em uma série de melhorias com o intuito de aumentar a segurança, como, por exemplo, no monitoramento eletrônico por meio de câmeras, em obras civis para correção do projeto original, o que inclui a substituição de grades, a colocação de portões adicionais, instalação de cercas elétricas, construção de celas especiais de isolamento e um canil. Segundo a empresa contratada, os investimentos, da ordem de US\$ 400 mil, foram realizados por iniciativa própria da empresa, sem nenhuma contrapartida do governo do Estado. Uma vez que o operador privado se apropria, ao menos de parte considerável, do retorno decorrente da redução de conflitos internos e motins, estão dados os incentivos econômicos para a realização desses investimentos. Adicionalmente, a redução de fugas também impacta positivamente o fluxo de renda futura do operador privado, por abrir novas oportunidades de gestão de presídios.

As normas sociais que disciplinam o comportamento dos presidiários tornam os esquemas de monitoramento mais complexos. A percepção da regras informais inerentes ao sistema prisional, sua apreensão e o uso conjunto com as regras formais não é algo trivial. Como fruto da convivência com os internos, a qual se dá em muitas vezes na tênue linha entre a legalidade e a ilegalidade, é de se esperar que alguns dos agentes penitenciários sejam suscetíveis à corrupção. 
A fim de minimizar estas possibilidades, a operadora privada conduz periodicamente investigações particulares sobre as condutas externas e sobre as condições sócio-econômicas de seus agentes de disciplina como forma de se detectar eventuais ligações de seus funcionários com internos. Como resultado, durante 2003 e 2004, 15 agentes foram demitidos. O próprio operador admite que, em parte, estas demissões podem não ter sido totalmente justas, porém ele se vale da máxima: “Na dúvida, demite-se!”. Dificilmente em qualquer unidade sob gestão integral do Estado seria possível tanto a execução de investigações sistemáticas deste quilate, quanto a apuração e a aplicação de punições aos transgressores em prazo tão rápido.

A possibilidade de rescisão do contrato de trabalho na governança privada constitui forte instrumento para inibir a corrupção de funcionários por presidiários e seus parceiros que ainda operam atividades criminais fora da unidade prisional. Em contrapartida, aumentam-se os custos decorrentes da rotatividade de pessoal, sobretudo aqueles ligados à perda de capital humano específico (WILLIAMSON, 1996), estes últimos com implicações negativas no que se refere ao conhecimento das normas dos internos, cujos efeitos devem ser avaliados em uma perspectiva de longo prazo. Por outro lado, a prisão pública apresenta altos níveis de rotatividade nos cargos diretivos. Frequentes fugas e reclamações de uso abusivo da força forçaram tais mudanças, contrastando com o CPV onde se verifica estabilidade nas esferas de comando.

Em função da inexistência de cláusulas contratuais que penalizem o operador privado no caso de fugas, poderia se supor uma possível cumplicidade da empresa com internos, de modo a facilitar fugas. Contudo, observando-se o número de fugas, zero no período analisado, refuta-se esta suposição. Dois fatores explicam esse tipo de comportamento: o constante monitoramento dos funcionários do Estado e, principalmente, a preocupação da empresa privada com sua reputação, essencial para sua habilitação em novas licitações no futuro.

A quarta razão está relacionada ao nível ótimo de delegação de autoridade e de direitos de decisão. Um problema da governança pública é a impossibilidade de delegar formalmente direitos de decisão às esferas administrativas inferiores, o que pode ser desejável se houver custos distintos de obtenção e processamento da informação nos dife- 
rentes níveis administrativos. (AGHION; TIROLE, 1997) Para que esses direitos formais constituam direitos econômicos, é necessário incorrer em custos de mensuração de informação para garantir tais direitos. (BARZEL, 1997) Dado que, na governança pública, os direitos formais não podem ser delegados a esferas administrativas inferiores, há maiores custos decorrentes de mensuração da informação, cuja observação ocorre muitas vezes nas esferas inferiores. Efetivamente, a direção, embora detenha os direitos formais, não dispõe de informação suficiente para exercê-los eficientemente, com desdobramentos negativos para a flexibilidade e agilidade da operação. Em contraste, o contrato firmado entre governo e empresa prevê a delegação de uma série de diretos formais, tais como responsabilidade por compras e contratação de pessoal. Conforme sustenta Hart (1995), a delegação de atividades pode moldar os incentivos dos agentes econômicos. Por outro lado, sob a perspectiva de quem delega, esta conduta pode contribuir para a focalização sobre as atividades essenciais. No caso da forma pública, os gestores responsáveis pela unidade necessitam também interagir 68 com uma série de outras agências governamentais para garantir, por exemplo, o suprimento de saúde, educação e trabalho aos internos, o que engendra fricções (ou custos de transação) e, consequentemente, maior lentidão para a obtenção dos fatores necessários ao correto funcionamento da unidade. Se a delegação ocorre - como no modelo de governança privado aqui analisado - os esforços de coordenação e monitoramento diminuem, uma vez que o número de interlocutores é reduzido. Desta forma, ao menos no presente caso, a flexibilidade propiciada pelas formas privadas mostra-se positiva.

Os controles impostos pela administração pública vêm influenciando negativamente o desempenho do CPTF. De um lado, eles são ambíguos e falham na inibição de condutas indesejáveis dos funcionários públicos, por outro eles são rígidos a ponto de tornarem as operações inflexíveis, sobretudo no que se refere aos procedimentos de compra e de contratação de funcionários. Conforme observado, a superior flexibilidade no CPV é responsável pelos melhores índices de assistência médica providos aos internos, visto que a contratação de um novo profissional não requer a abertura e a realização de concurso público. 


\section{Considerações finais}

Prisões se distinguem de outros serviços de utilidade pública. A combinação de instituições formais e informais e a maneira com que os gestores lidam com tais restrições são cruciais na determinação para a conformação dos indicadores de desempenho. A análise comparativa de duas unidades penais similares - uma totalmente gerenciada pelo poder público e outra com sua operação terceirizada junto a uma empresa privada - propicia algumas considerações relacionadas ao desenho organizacional apropriado para a provisão de serviços prisionais.

As evidências empíricas demonstram que a operadora privada atingiu melhores indicadores de desempenho nas esferas administrativas, ligadas à segurança e ordem da unidade e no que se refere aos serviços de bem-estar oferecido aos internos. Quatro grandes fatores podem explicar tais diferenças: a) menores níveis de controles administrativos; b) incentivos mais fortes na governança privada para: monitoramento dos empregados e cumprimento contratual; c) busca de soluções às restrições institucionais encontradas, como por exemplo, ineficiências do judiciário; d) presença de funcionários públicos no interior da unidade terceirizada, com efeitos na redução do nível de informação assimétrica.

Igualmente, a implementação de mecanismos de recompensas e punições é essencial para a gestão adequada de unidades prisionais. Neste sentido, a modalidade privada de governança utiliza a possibilidade de rescisão contratual como instrumento de prevenção de arranjos ilícitos. As altas taxas de rotatividade (turnover), por outro lado, limitam a acumulação de capital humano específico, sobretudo no que tange ao conhecimento das normas informais dos internos. $\mathrm{O}$ trade-off entre risco de corrupção e ganhos decorrentes do aprendizado das normas sociais dos internos determina o nível ótimo de turnover, necessitando ser analisado de forma mais cuidadosa em estudos futuros. Corroborando Williamson (1999), os menores níveis de controles administrativos conferem ao operador privado maior flexibilidade, face às restrições encontradas, sobretudo àquelas ligadas a procedimentos de compras e assuntos legais.

Percebeu-se também que os agentes estatais puderam, por conta da convivência com atores privados, melhorar as especificações ex- 
-ante em novos contratos de concessão, o que pode contribuir para a diminuição dos custos de transação ex-post. Além disso, como resultado do conhecimento da estrutura de custos da operadora privada, o governo estadual passou a especificar o valor máximo a ser pago pelos serviços de operação, o que proporciona a redução da possibilidade de condutas oportunistas por parte das empresas privadas via exploração da informação assimétrica.

Evidentemente, pesquisas adicionais são bem necessárias. No entanto, tal fato ainda esbarra na dificuldade de obtenção de informações sobre o setor, seja por conta da inexistência de dados consolidados, seja por dificuldades impostas pelas administrações penitenciárias para sua disponibilização, sobretudo as informações ligadas a desvios de conduta na administração e no interior do cárcere. O desafio consiste justamente em contornar tais dificuldades para poder, desta forma, aumentar os conhecimentos sobre os temas ligados ao mundo prisional, o que é imprescindível para a formulação de políticas públicas futuras para o setor.

\section{Referências}

AFFONSO, D. K. Privatização de Presídios: Terceirização dos Serviços Penitenciários. 2002. 123 f. Dissertação (Mestrado) - Faculdade de Direito, Universidade de São Paulo, 2002.

AGHION, P. and TIROLE, J.Formal and Real Authority in Organizations. Journal of Political Economy, v. 105, n. 1, p.1-29, feb. 1997.

ARAUJO, J.M. Privatização das Prisões. São Paulo: Revista dos Tribunais, 1995.

ARCHEOEMBEAULT, W.G. and DEIS, D.R. Cost-Effective Comparisons of Private Versus Public Prisons in Lousiana: A comprehensive analysis of Allen, Avoyelles ad Winn Correctional Centers. Lousiana State University: Research paper, 1996. 79 p.

BARZEL, Y. Economic Analysis of Property Rights. 2. ed. Cambridge Univ. Press, 1997.

BAYER, Patrick; POZEN, David. The effectiveness of juvenile correctional facilities: public versus private management Journal of Law and Economics, v. 48, p. 549-589, oct. 2005.

BLUSTEIN, James F; COHEN, Marc A. The interrelationship between public and private prisons: Does the existence of prisoners under private 
management affect the rate of growth in expenditures on prisoners under public management. Lousiana: ACSME, 2003. 11 p. (mimeo).

BRICKLEY, J., COLES, J;JARREL, G.. Leadership Structure: Separating the CEO and Chairman of the Board. Journal of Corporate Finance, v. 3, p. 189-220, 1997.

CABRAL, Sandro. Além das Grades: uma análise comparada das estruturas de governança do sistema prisional.(Tese de Doutorado) - Núcleo de Pós Graduação em Administração, Universidade Federal da Bahia, 2006.

CABRAL, Sandro. Sobre a participação privada na gestão e operação de prisões no Brasil: uma análise à luz da Nova Economia das Instituições. O\&S. Organizações \& Sociedade, v. 14, p. 29-47, 2007.

CABRAL, Sandro; AZEVEDO, Paulo F. The Modes of Provision of Prison Services in a Comparative Perspective. BAR. Brazilian Administration Review, v. 5, p. 53-69, 2008.

CABRAL, Sandro; LAZZARINI, S.G.; AZEVEDO, P.F. Private Operation with Public Supervision: Evidence of Hybrid Modes of Governance in Prisons. Public Choice, v. 145, p. 281-293, nov. 2010.

CABRAL, Sandro; LAZZARINI, S.G.; AZEVEDO, P.F. Private Entrepreneurs in Public Services: A Longitudinal Examination of Outsourcing and Statization of Prisons, Strategic Entrepreneurship Journal, 2012. No prelo.

DIRECTION DE L'ADMINISTRATION PENITENTIAIRE. Ministère de la Justice, République Française. Les chiffres clés de l'administration pénitentiaire. Paris: Techniques \& Impressions, Mai, 2004.

D’AMICO, Daniel J. The prison in economics: private and public incarceration in Ancient Greece. Public Choice, v. 2, dec. 2009.

D`URSO, L.F.B. A privatização dos presídios (Terceirização). 1996. 247 f. Dissertação (Mestrado) - Faculdade de Direito da Universidade de São Paulo, Universidade São Paulo, 1996.

GUPPY, Paul. Private Prisons and the Public Interest: Improving Quality and Reducing Cost through Competition. Washington Policy Center, p. 13, feb. 2003.

HART, O.; SHLEIFER, A;VISHNY, R.W. The Proper Scope of Government: Theory and an Application to Prisons. Quarterly Journal of Economics, v.112, n. 4, p. 1127-1161, nov. 1997.

HART, O. Incomplete Contracts and Public Ownership: Remarks and Application to Public-Private-Partnerships. Economic Journal, Royal Economic Society, v. 113, n. 486, p. 69-76, 2003. 
LAZERGES, Christine Les Établissements Pénitentiaires à Gestion Mixte: À l'eprouve de l'observation. In: LAFARGE, Philippe. Établissements Pénitentiaires à Gestion Mixte: Actes du Colloque de Montpellier. Paris: Ed. Pedone 1997. p. 79.

LEVY, Brian; SPILLER, Pablo T. The institutional foundations of Regulatory Commitment: A comparative analysis of telecommunications regulation. The Journal of Law, Economics and Organization, v.10, p. 201-246, 1994. MÉNARD, Claude The economics of hybrid organizations. Journal of Institutional and Theoretical Economics, v. 160, n. 3, p. 1-32, 2004. MINHOTO, Laurindo Dias. Privatização de presídios e criminalidade: a gestão da violência no capitalismo global. São Paulo: Editora Max Limonad, 2000. $214 \mathrm{p}$.

MITCHELL, Matthew. The Pros of Privately-Housed Cons: New evidence on the Cost Savings of Private Prisons. New Mexico: Rio Grande Foundation, 2003. $21 \mathrm{p}$.

MORRIS, John. C. Government and Market Pathologies of Privatization: The Case of Prison Privatization. Politics \& Policy, v. 35, n.2, p. 318-340, 2007.

NORTH, Douglass. Institutions, Institutional Change and Economic Performance. Cambridge: Cambridge University Press, 1990. 152 p. OSTROM, Vincent and OSTROM, Elinor Public Goods and Public Choices. In: SAVAS, E.S. (Ed.). Alternatives for Delivering Public Services: Toward Improved Performance. Boulder: Westview Press, 1977. p. 7- 49.

SHIRLEY, Mary; MÉNARD, Claude. Cities awash: a synthesis of the country cases. In: SHIRLEY, Mary (Ed.) Thirsting for Efficiency: The Economics and Politics of Urban Water System Reform. Oxford: Elsevier Science, 2002. p. 1-42.

U.S. DEPARTMENT OF JUSTICE. Prison and jail inmates at the mid of 2009. Bureau of Justice Statistics Bulletin. Office of Justice Programs, octob, 2009.

VARELLA, Drauzio. Estação Carandiru. São Paulo: Cia. das Letras, 1999. $297 \mathrm{p}$.

VIGGIANO, Fernando Braga Endurecimento das penas e da execução penal: retrocesso inigualável. Revista de Informação Legislativa, Brasília, n.156, p. 25-31, out/dez. 2002.

WACQUANT, Loïc As prisões da miséria. Rio de Janeiro: Zahar, 2001. 174 p. 
WILLIAMSON, Oliver. The Mechanisms of Governance. Oxford: Oxford University Press 1996.

WILLIAMSON, Oliver Public and Private Bureaucracies: A Transaction Cost Economics Perspective. Journal of Law, Economics and Organization, v. 15, n.1, p. 306-342, mar. 1999. 


\section{A análise da rede de vínculos de autores de delitos como uma contribuição para a compreensão do comportamento delituoso: um estudo de caso ${ }^{1}$}

Odilza Lines de Almeida

\section{Introdução}

Este capítulo tem por objetivo apresentar a análise da rede de vínculos como uma contribuição para os estudos criminológicos, especialmente no que se refere ao desenvolvimento do comportamento delituoso. Para tal mister, conduzimos uma pesquisa de metodologia mista com o objetivo de identificar, numa unidade prisional, pessoas que assumiram ter uma trajetória delituosa e que se auto-intitulavam como sendo "do crime" e o impacto dos vínculos construídos durante

1 Este trabalho é proveniente da dissertação Histórias de (des)vínculos: um estudo com autores de delitos em regime de privação de liberdade, defendida no Programa de Pós-Graduação em Psicologia da UFBA e orientada pela Profa. Dra. Sonia Maria Rocha Sampaio, a quem renovo meus sinceros agradecimentos. 
o ciclo de vida no estabelecimento e na consolidação de uma carreira delituosa.

Esclarecemos que 'autores de delitos' são aqui vistos de modo similar aos desviantes de Becker (1996), isto é, como aqueles para quem o rótulo foi aplicado com sucesso posto que internalizado. Não é, portanto, uma qualidade da pessoa ou do ato que a pessoa comete, per si, mas uma conseqüência da aplicação por outros, de regras e sanções àqueles que transgridem as normas do grupo social. Já o conceito de 'carreira', também utilizado por esse autor, faz referência à sequência de movimentos dentro de um sistema e às contingências das quais depende essa mobilidade.

Consideramos, pois, que a rede de vínculos é uma dessas contingências e para sua análise desenvolvemos um modelo teórico (Figura 1), numa abordagem sistêmica, que privilegia os vínculos estabelecidos nos diversos contextos de desenvolvimento. Esse modelo foi construído a partir de uma perspectiva multirreferencial que articula pressupostos das seguintes abordagens: a Teoria do Controle Social (HIRSCHI, 2003), do campo da criminologia; a Teoria da Socialização Primária (OETTING; DONNERMEYER, 1988), proveniente da Psicologia Social e as Teorias do Apego (BOWLBY, 1984) e Ecológica (BRONFENBRENNER, 1979, 1986, 1996), oriundas da Psicologia do Desenvolvimento. Assim, partimos da concepção de que a rede de vínculos - conjunto envolvendo a pessoa e as relações que estabelece com seu meio - facilita ou não o envolvimento com o crime, considerando que as ligações estabelecidas entre os atores propiciam controles internos e externos. Foram tanto analisadas a configuração da rede (amplitude medida pelos contextos presentes), seu tamanho, estrutura e homofilia (relações com pessoas que cometem delitos) bem como reconstruídas as redes referentes aos períodos cruciais do desenvolvimento (infância, adolescência) e construídas as redes representativas do momento da pesquisa, quando o informante se encontrava em reclusão, e das expectativas do autor de delito ao sair da prisão. 


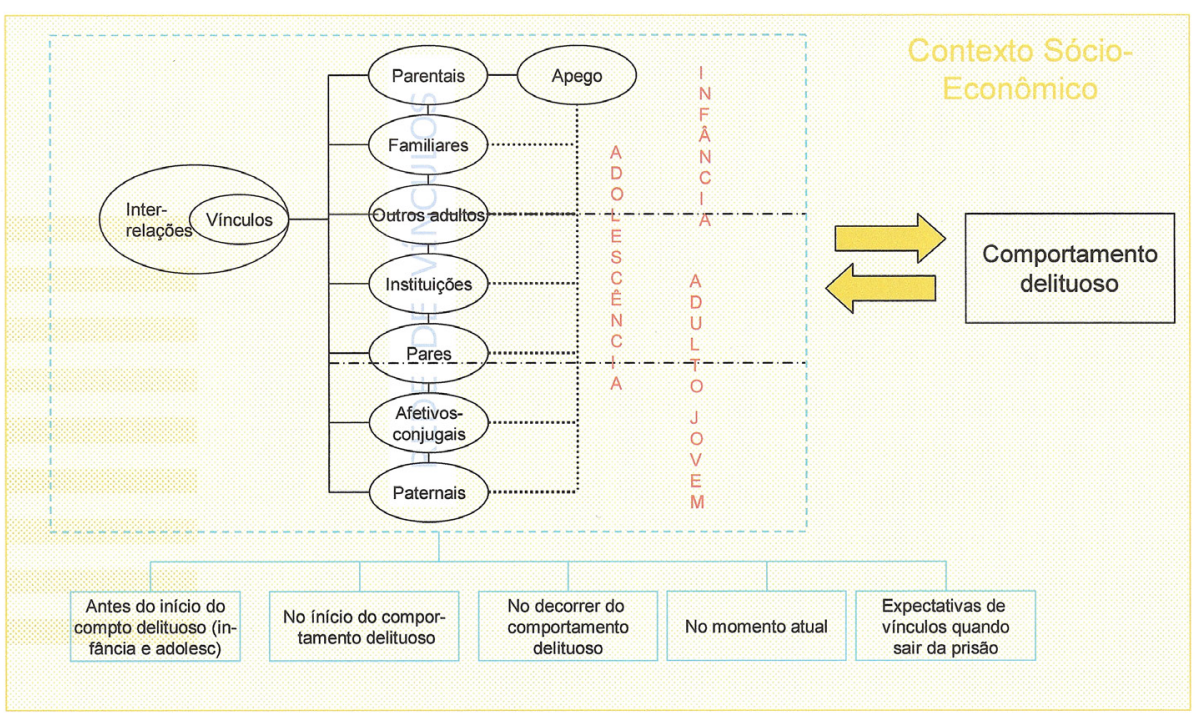

Figura 1- Modelo Teórico

Fonte: própria autora

Nesse modelo, compreendemos que o vínculo é um "espaço privilegiado de construção e de persistência de coisas compartilhadas" (CARVALHO, 2005), e é considerado como uma relação particular com um outro significativo, assumindo como pressupostos: a) a impossibilidade de ausência total de vinculação no contexto da vida humana; e b) que o vínculo comporta afeto positivo ou negativo, não implicando juízo de valor moral e constitui mecanismo de identidade e lugar no mundo. (CARVALHO, 2005) Carvalho (2005 apud BASTOS et al., 2006) propõe, ainda, para fins de sua análise que o vínculo seja considerado como "um padrão diferencial de interações entre parceiros em uma situação social, expressando seletividade em relação a certos parceiros ao longo de um período de tempo" (grifo do autor). Dessa forma, o vínculo comporta duas dimensões: seletividade e durabilidade. Assumimos a "durabilidade" enquanto repercussão e internalização - o que a Teoria do Apego chama de "modelo de representação" - daquelas relações estabelecidas e que perduram por um período considerável de tempo na trajetória de vida. Foram consideradas as relações e os vínculos estabelecidos com figuras parentais (pai, mãe ou substitutos); familiares (irmãos, tios, avós, primos etc.); outros adultos (professor, padres, pastores, pais de amigos, profissionais de instituições diversas etc.), pares (amigos e colegas de escola, trabalho); pessoas com quem 
mantêm vínculos amorosos íntimos (namorada, esposa, companheira etc.); com pessoas com as quais têm uma relação paternal (filhos, enteados, sobrinhos etc.) e com instituições (escolas, igrejas, casas de acolhimento, de programas sociais etc.).

De posse desse modelo, fomos a campo para identificar esses diversos vínculos na trajetória de adultos em regime de privação de liberdade. Apresentamos a seguir a análise da narrativa de um deles, Fernando, que cometeu um crime considerado grave, dentro do escopo do trabalho². Sua história foi reconstruída numa Linha de Vida na qual foram sistematizados os principais eventos narrados e os sentimentos e julgamentos relacionados a esses eventos, o que forneceu uma idéia da trajetória individual. A partir dessa sistematização as redes de vínculos foram identificadas e representadas graficamente através de genogramas, ${ }^{3}$ proporcionando uma compreensão de sua configuração nos diversos momentos do seu percurso até o momento da pesquisa.

\section{A história e a rede de vínculos de Fernando}

No momento da entrevista, Fernando contava com 22 anos e estava preso há 33 meses por homicídio qualificado, delito considerado grave. Os autos do processo relatam que Fernando desferiu uma série de socos na vítima - com a qual mantinha um relacionamento amoroso - que desmaiou depois de bater a cabeça numa pedra. Fernando, em sua narrativa, banaliza o delito: "Se tivesse justiça não era nem pra mim nem tá preso por causa do B.O. [boletim de ocorrência] que eu tive: a pessoa foi morta com um murro, com um murro só, e eu tô até hoje preso".

É o terceiro filho de uma prole de quatro, cada um de pai distinto. Mãe alcoólatra, ele e os irmãos são criados com a ajuda da avó materna e de um padrasto - que vai entrar em sua vida quando tinha por volta de oito anos e pelo qual demonstra grande gratidão e consideração:

2 "Delito" é aqui considerado como ação ou omissão, dolosa ou culposa, tipificada pelos Códigos legais vigentes. Os delitos foram classificados em: "leves" - com sanções previstas até 4 anos de reclusão, passíveis de serem transformados em penas alternativas, conforme o art. 44 do Código Penal (Decreto-Lei 2848, 1940); graves - aqueles tipificados pela Lei de Crimes Hediondos (Lei 8.072, 1990) e médios (os demais delitos que não se encaixam nos anteriores).

3 A rede de vínculos foi descrita de forma gráfica através de uma adaptação da técnica do genograma, utilizando-se o software GenoPro (v. Beta). 
"Pra mim, ele é mais do que um pai". Pelo pai biológico manifesta ressentimento por ele o ter deixado pequeno na barriga da mãe que, segundo ele, sofreu muito para criar os filhos. Vê o pai por uma única vez aos nove anos, mas "não dá muita ligança".

A infância de Fernando transcorre dentro do esperado para qualquer criança de seu estrato social: mora em um bairro popular, composto por pessoas de classe média baixa, mas com equipamentos disponíveis para a comunidade como escolas, igrejas, campo de futebol, além de sua localização ser próxima ao centro da cidade. As ruas desse bairro são calçadas, dispõem de água e luz. Vê o bairro como local de pessoas boas, não faz referência à violência ou a outras situações de risco. Teve dois amigos de infância com os quais brincava de bola, pipa, gude e que eram considerados como irmãos. Frequentou a escola até a segunda série. A análise da rede de vínculos, até aqui, fornece a seguinte configuração:

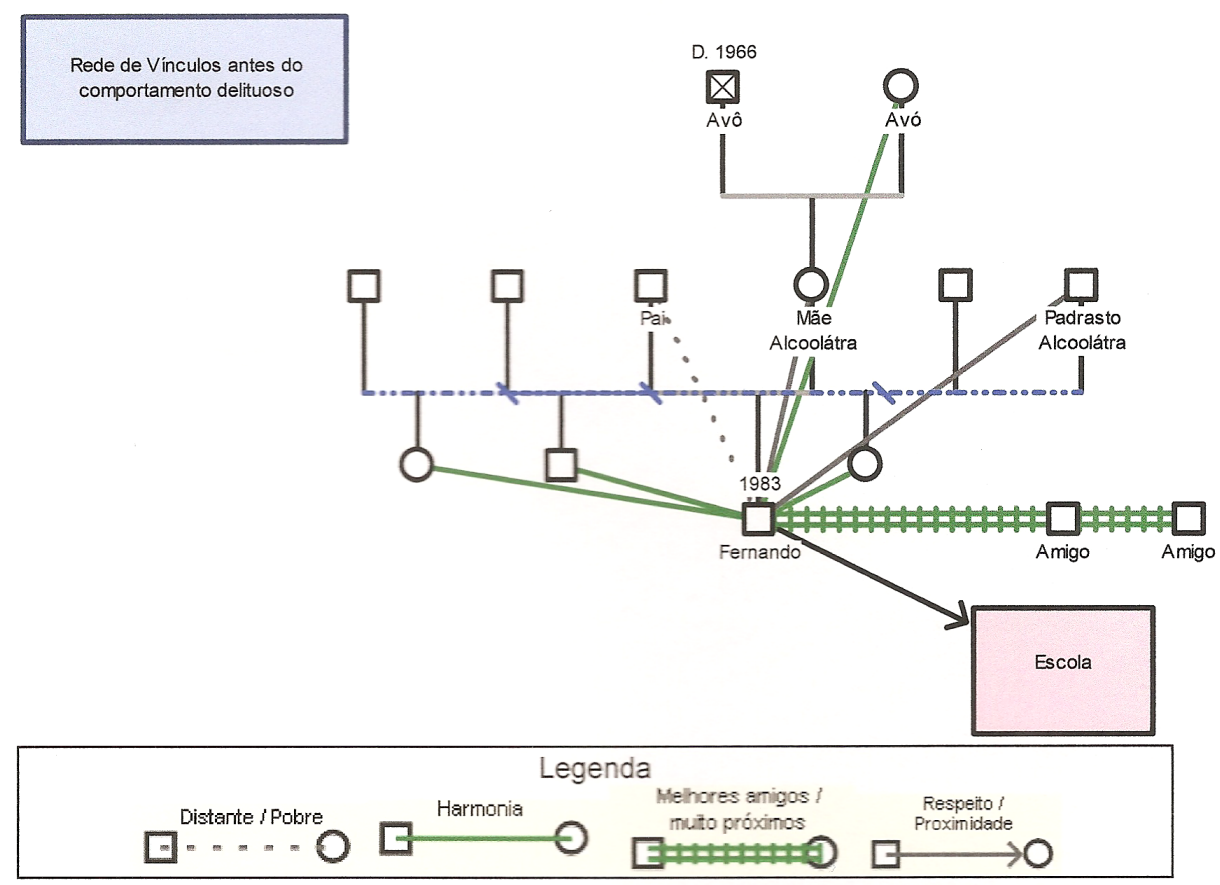

Figura 2 - Rede de vínculos antes do comportamento delituoso de Fernando Fonte: própria autora 
Fernando fornece um retrato de sua infância, momento que precede o início do comportamento delituoso, no seu caso. Nesse retrato, podemos identificar algumas particularidades como, por exemplo, a estruturação familiar. Parece haver um consenso, na área de conhecimento da Psicologia, de que a família tem uma função mediadora inquestionável no desenvolvimento do indivíduo nos primeiros anos de vida e seu impacto como agente socializador tem sido estudado tanto na psicologia do desenvolvimento quanto na psicologia social. Cabe, porém, lembrar que os modelos de família e, consequentemente, sua função e papéis acompanham o contexto histórico-social e econômico. Concordamos com Neder (2000, p. 28) quando considera que:

não existe, histórica e antropologicamente falando, um modelo-padrão de organização familiar; não existe a família regular. Menos ainda que o padrão europeu de família patriarcal, do qual deriva a família nuclear burguesa (que a moral vitoriana da sociedade inglesa no século XIX atualizou historicamente para os tempos modernos), seja a única possibilidade histórica de organização familiar a orientar a vida cotidiana no caminho do progresso e da modernidade. Pensar a família de forma plural pode significar uma construção democrática baseada na tolerância com as diferenças, com o Outro (grifos do autor).

A estrutura da família de Fernando foge ao padrão burguês de família. É um dos tantos modelos encontrados na sociedade contemporânea. Apesar das dificuldades e dos problemas encontrados neste contexto - "Essa época minha foi uma época muito precária mesmo que só a minha família, só minha mãe e minha vó trabalhava”-, essa família buscava dar o suporte e os referenciais necessários para o desenvolvimento de Fernando: "Ah, era bom. Todo mundo respeitava o outro. Até hoje, o relacionamento meu e dos meus irmãos é tudo... um ajudando o outro... Se um tá passando aperto, o outro ajuda outro. [...] É uma família unida." Nesta configuração, a avó tem um papel importante de suporte financeiro, moral e emocional. Fernando relata que a avó criou todos e sempre foi a figura a quem todos sempre respeitaram.

Aqui lembramos Kehl (2003) que faz uma reflexão sobre essas novas configurações, lembrando que o modelo familiar vigente como "regular" ou "normal", na verdade, vigorou por pouco tempo na história ocidental - do início do século XIX a meados do século XX. As condições econômicas, os métodos anticoncepcionais e a mudança do 
papel da mulher na sociedade também contribuem para as modificações da estrutura familiar e das funções que a mulher passa a assumir nessas novas estruturas. Há, contudo, ainda lembra Kehl (2003), todo um discurso de endeusamento da família oitocentista, patriarcal, bem como a responsabilização de sua "dissolução" pelos problemas de degradação social em que vivemos. Esse discurso pode ser percebido na mídia, alimentado por profissionais diversos os quais teimam em reproduzir teorias que não contemplam a pluralidade da família e dos demais contextos de desenvolvimento, além de criar necessidades em torno dessa família "ideal".

E à família já não se pode mais exigir que venha a suprir sozinha todas as necessidades da pessoa em formação e, ainda, que venha a arcar com toda a sua formação moral, identitária e social. Diz Reis (1985, p. 112):

Enquanto a criança aristocrata, a camponesa ou mesmo a operária se defrontavam com uma ampla gama de possibilidades de identificação, a criança burguesa tinha apenas as figuras parentais, ou acabava tendo na realidade apenas um objeto de identificação - o progenitor do mesmo sexo - em virtude da rigorosa divisão de papéis sexuais que presidia sua vida familiar.

Mas o que nos diz Fernando sobre essa estrutura?

Eu mesmo, pra ser sincero pra senhora, eu nunca nem senti falta dele [do pai] não... Que nunca me ajudou em nada, nunca me deu nada, nunca se importou por mim. [...] Eu já tive um padrasto já... Meu padrasto pra mim.. até hoje ele é vivo. Pra mim ele tem mais valor do que meu pai que me botou no mundo, que me fez. [...] Ele não é meu pai biológico, mas pra mim ele é mais do que um pai. Pra mim ele é tudo... Que esse aí que ajudou minha mãe a criar meus irmãos, foi ele que, ele que fez tudo, até hoje... Até hoje ele ajuda minha família.

Além da família, Fernando frequentava o contexto da escola, da rua nas brincadeiras com os pares e das casas dos amigos próximos. $\mathrm{O}$ modelo bioecológico de Bronfenbrenner (1979, 1986, 1996) considera-os como microssistemas e ressalta que a relevância das experiências nesses ambientes não se refere aos dados objetivos, mas ao modo como o ser em desenvolvimento percebe e experiencia esse contexto. Especifica, ainda, propriedades do ambiente que estimulam o processo de desenvolvimento. Dentre elas, podem ser citadas as interconexões entre os ambientes, 
as quais favorecem atividades compartilhadas e a comunicação de via dupla, e a quantidade de ambientes desenvolvimentais. Fernando não relata problemas como o alcoolismo da mãe e do padrasto, dados que foram fornecidos pela irmã mais velha através de um contato informal. Percebe-se, porém, que as interconexões entre os ambientes eram pobres: a família, por exemplo, não acompanhava o desempenho escolar; não se percebe, na sua narrativa, o movimento da família em torno desse aspecto da vida de Fernando. É um mesossistema fragilmente vinculado. Além disso, a quantidade de ambientes parece restrita.

No decorrer de sua trajetória, algumas características da rede de vínculos vão se modificando. Não parece haver causas específicas, nem vínculos que antecedem outros para essas mudanças, mas sim um movimento sincrônico de fortalecimento de alguns vínculos e deterioração de outros. Como numa mandala tridimensional, o movimento em uma parte modifica outras partes vinculadas e reestrutura o todo. A rede de vínculos vai se reestruturando na medida em que ligações são fortalecidas, desfeitas ou fragilizadas, de forma sistêmica, global. Essa re-estruturação pode ser visualizada na configuração da rede de vínculos, verificada no início do comportamento delituoso, aos doze anos:

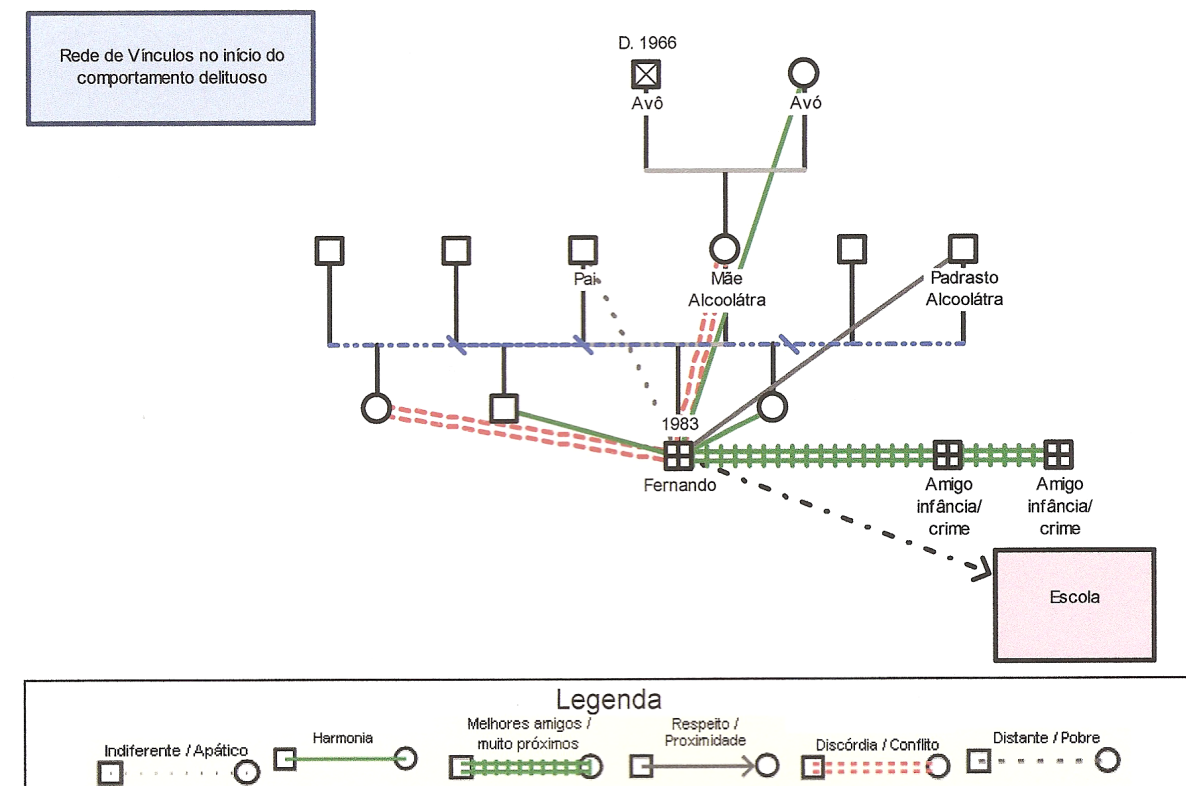

Figura 3 - Rede de Vínculos no início do comportamento delituoso de Fernando Fonte: própria autora 
Nota-se que alguns vínculos com membros da família nuclear estão enfraquecidos e constituem fontes de conflito (irmã mais velha e a mãe). Esse enfraquecimento está associado aos novos comportamentos apresentados - comportamento delituoso - e às mudanças de vínculos como o afastamento da escola, além da presença de companheiros (melhores amigos e muito próximos) que também apresentam comportamento delituoso.

A Teoria da Socialização Primária de Oetting e Donnermeyer (1998) defende que tanto o comportamento pró-social quanto o desviante seriam aprendidos no processo de socialização primária. Na sociedade ocidental, as fontes de socialização primária durante a adolescência seriam a família, a escola e o grupo de pares e cada uma dessas fontes envolve laços que fornecem canais para comunicação de normas. Ao aplicá-la à configuração encontrada no início do comportamento delituoso de Fernando e à narrativa coletada - "Minha vó, minhas irmã, meus irmão, tudo me aconselhava pra eu sair desse mundo"-, observa-se que apesar da presença das normas e dos vínculos pró-sociais no contexto da família nuclear, o comportamento delituoso se instalou. Outros agentes da socialização primária - escola e pares - parecem ter contribuído para esse acontecimento. O frágil laço com a escola principal agente socializador nessa teoria - juntamente com a aprendizagem ocorrida com os pares proporcionaram o ambiente propício à instalação do comportamento delituoso. Não se nota o apego, tanto no sentido de Bowlby quanto de Hirschi da Teoria do Controle Social, pois Fernando não se apresentava sensível à opinião dos familiares e, consequentemente, o comprometimento às regras estabelecidas estava enfraquecido. O envolvimento com tarefas convencionais foi sendo abandonado. As crenças eram compartilhadas, mas parecem terem sido internalizadas de forma débil e, assim, não foram eficazes para impedir a instalação do comportamento delituoso, provavelmente em função da força de outros vínculos.

Verifica-se também, neste momento, a restrição dos ambientes pelos quais Fernando circula. Não há uma expansão dos contextos de desenvolvimento. Fernando não se envolve profundamente com instituições ou com outros amigos. Sua rede pode ser caracterizada como pobre, o que dificulta a internalização de outros valores e do compartilhamento de outras crenças. O mundo era o que estava ali 
apresentado, e para tal mundo uma única possibilidade parecia-lhe existir.

Ao narrar como se deu o início do comportamento delituoso, diz Fernando:

Uma loucura da mente... Nois foi no centro, aí chegou ali na feira do Paraguai... Eu e outro... Aí um passou e levou uma calculadora, outro passou, levou um relógio... Aí nois vendeu, pegou o dinheiro, jogou vídeo-game, voltou de novo... Aí eu peguei um mini game e os outros, cada um pegou um relógio... Aí desse dia pra cá, começou... rouba isso, rouba aquilo... loucura de pivete...

Roubavam por prazer, pelo lúdico. O fruto do roubo também era revertido para esse fim ou ainda para adquirir roupas, bens de consumo. Wieviorka (1997), ao analisar a violência no nível individual, ${ }^{4}$ chama a atenção para um aspecto que foi colocado inicialmente nesse trabalho: a relação da violência com a busca da produção de sentido. $\mathrm{O}$ autor entende que o individualismo do mundo contemporâneo apresenta duas faces: o desejo de participar e de compartilhar do que a modernidade oferece e a necessidade de ser reconhecido como sujeito. O comportamento delituoso parece servir como um instrumento de acesso ao mundo prometido pelos meios de comunicação. A possibilidade de consumir e a ostentação dos bens adquiridos conferem ao autor de delitos um reconhecimento, uma visibilidade que lhe é constantemente negada no cotidiano. Fernando explica: "Pra mostrar pros outros aquele poder sem ter poder nenhum, mostrar que pode ter alguma coisa, mas sem ter nada, só ilusão mesmo da mente. Botou uma ilusão na mente e parece que vendou foi os olhos".

Garland (2002) esclarece que a chamada "nova criminologia da vida cotidiana” tem modificado a visão do crime e do autor de delitos. As versões do indivíduo inadaptado, carente afetiva e socialmente, deficiente e perigoso estão sendo substituídas pela figura do consumidor hedonista comum. "É simplesmente uma versão crua do indivíduo moderno, cuja 'identidade' depende de uma escolha de consumo e de imagens de si mais do que de formação moral, compromisso de valor ou autocontrole". (GARLAND, 2002, p. 78)

Apesar das dificuldades que a família enfrentava, Fernando não atribui à situação financeira familiar a sua entrada no mundo do cri-

4 Esse autor considera, ainda, os níveis internacionais, dos Estados e das sociedades. 
me: "Essa época foi uma época muito precária mesmo pois na minha família, só minha mãe e minha vó trabalhava. Aí nois passava muitas necessidades. Mas nem foi por causa disso não. Foi mais mente fraca mesmo". E o que seria "mente fraca", Fernando? "Mente fraca é a pessoa que não pensa o que vai fazer... Faz por impulso... Pensa uma coisa e já pensa que aquilo é o certo... Não pára pra pensar as coisa certa pra fazer. E cada vez que vai fazendo errado vai saindo errado."

Essa menção à "mente fraca" ou mesmo "cabeça fraca" e a dissociação entre situação econômica e comportamento desviante foram encontradas em outro trabalho que apresentava meninos de rua como foco. (SILVA, 1998)

A definição de "mente fraca" está também relacionada à influência de outras pessoas: "Os outro botava coisa na minha cabeça e eu achando que o crime era futuro". Esses outros eram os pares. Ao narrar como se deu o início do comportamento delituoso, relata Fernando:

Tinha um grupo nosso. Era uns dez, doze meninos, tudo de onze, doze, treze anos... Já tinha uns que era mais ligeiro, aí já botava na mente dos outro pros outro ir roubar pra ganhar dinheiro pra ir curtir, pra ter alguma coisa... Aí foi botando aquilo na cabeça e na hora que foi ver já tava envolvido no mundo do crime já... tão rápido... [...] toda noite, na esquina, ficava ali aquele grupinho, sempre todo dia naquele mesmo lugar e, no decorrer do dia a dia os que já roubava foi passando a idéia pros outros, aí daqui a pouco já estava todo mundo envolvido no crime...

Fernando e os seus amigos de infância encontraram juntos o caminho do crime. A influência dos amigos na adolescência no desenvolvimento do comportamento delituoso é verificada em Oetting e Donnermeyer (1998), quando discorrem sobre a vulnerabilidade da adolescência que é considerada como um período crítico, pois o potencial para aprender normas desviantes é relativamente alto. Fernando também teoriza sobre esse aspecto em particular:

Porque a pessoa de uma faixa assim de dez a, mais ou menos, uns quatorze anos, é muito fácil entrar na mente da pessoa dessa idade. Muito fácil mesmo. Porque a pessoa não tem raciocínio da mente e não tem conclusão do rumo que vai ser pra frente. Aí muitas vezes, o que a pessoa falar pra você é que é o certo. Mesmo que a mãe da pessoa chega e fala: 'ô meu filho, isso é errado', mas se o outro fala que é certo, a pessoa nessa idade, o raciocínio da mente dele é que o que o cara falou pra ele ali é o certo. Pode a mãe dele, o pai 
dele, todo mundo falar que é errado, mas pra ele é certo, que foi o que botaram na mente dele... Que foi o que aconteceu comigo...

Para Harris (1999, p. 225), "a meta da criança é ser uma criança bem sucedida” e não um adulto bem sucedido. É o mundo partilhado pelos grupos que constitui a referência de sucesso e competência, o que possibilita a transmissão da cultura. O grupo de pares serve para que a criança ou o adolescente possa se comparar ao outro e para se apropriar de um lugar, um status. A opinião e o julgamento por parte dos seus iguais têm um efeito devastador na construção da personalidade do indivíduo, defende Harris. Além disso, o grupo de pares constitui um espaço privilegiado de compreensão e de acolhimento diante das "incompreensões" familiares.

Mesmo envolvido no crime, Fernando trabalha com a mãe colhendo café. Também trabalha pegando carrego na feira. Relata que trabalhava muito e, nesse tempo, conheceu várias pessoas pelas quais nutre admiração como, barraqueiros e donos de loja na região em que trabalhava. Cita, inclusive, o dono de um bar pelo qual apresenta uma consideração que não tem pelos próprios parentes. Revela que essa pessoa testemunhou em seu processo na Justiça e se dispôs a ajudá-lo, coisas que os parentes não fizeram.

Fernando vivia em dois mundos: o mundo do trabalho e do relacionamento com pessoas "de bem" e o mundo do crime. Percebe-se a presença de outros adultos referenciais - o dono do bar - e de envolvimento com uma atividade produtiva. Os valores que eram difundidos em casa também estavam claros, mas numa análise mais minuciosa podem ser considerados ambíguos. Quando esclarece a utilização do dinheiro proveniente do roubo, Fernando revela:

Dinheiro de roubo não é aceito lá em casa não. Se for de roubo minha vó e minha mãe não aceitavam não. Podia, assim, dar alguma coisa pra minha mãe, pra minha avó. Aí eu comprava alguma coisa e dava; agora o dinheiro não aceitava não. Só algum dinheiro assim, quando eu ia trabalhar com alguma pessoa, ia pro café com minha mãe, aí eu chegava 'Aqui mãe, este dinheiro aqui é pra senhora'. Aí ela aceitava; agora dinheiro de roubo não aceitava não. Até hoje, não aceita não.

A adolescência de Fernando transcorre envolta no comportamento delituoso. Aos dezesseis anos, falece sua mãe. Esse momento é 
considerado um marco em sua vida: "Depois que minha mãe morreu, mudou totalmente. É diferente o modo de viver e de pensar. Eu antes eu só pensava em sair pra rua, em fazer zoeira, aprontar. Aí depois que minha mãe morreu, botei mais minha cabeça no lugar... mas só que não resultou em nada porque eu acabei vindo parar aqui nesse lugar...”.

Após a morte da mãe, a rede de vínculos de Fernando ficou assim configurada:

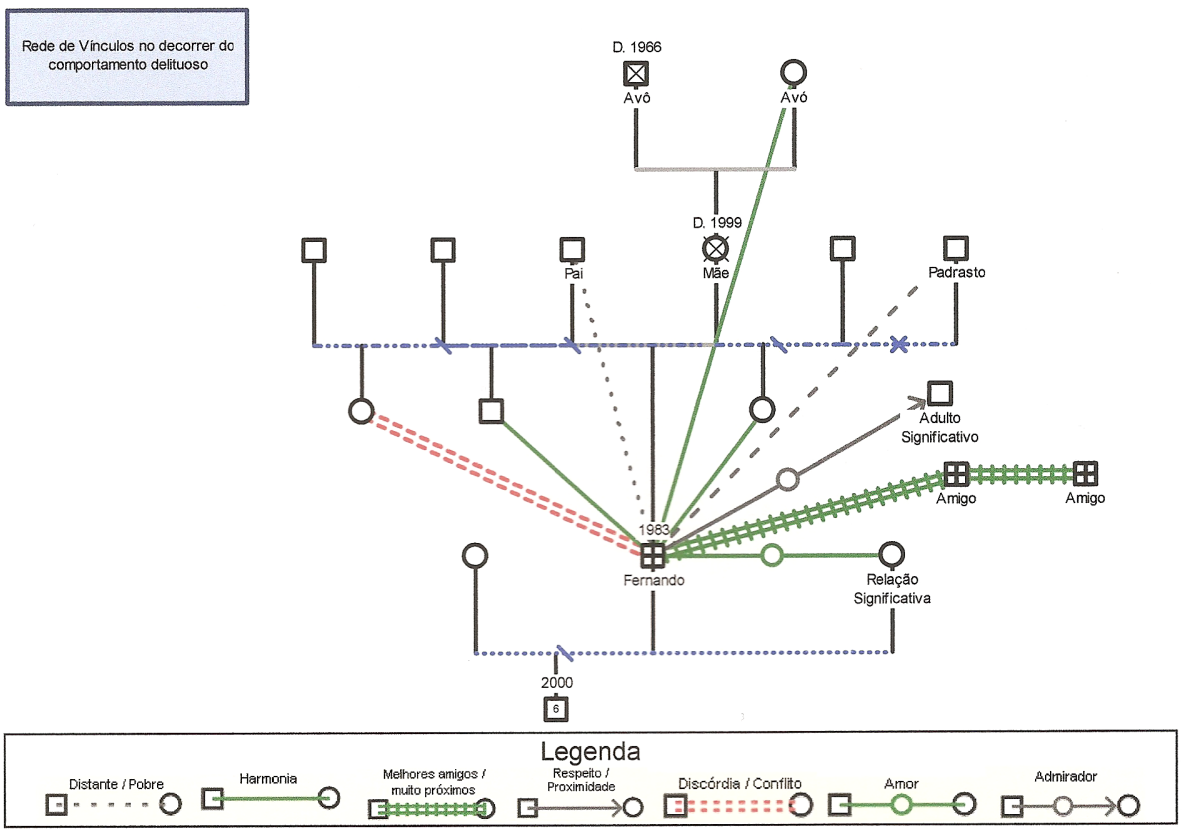

Figura 4 - Rede de vínculos de Fernando no decorrer do comportamento delituoso Fonte: própria autora

Mantém os vínculos familiares como antes se apresentavam. Nota-se o afastamento do padrasto que vai morar em outra casa após a morte da mãe, mas Fernando mantém o vínculo de admiração que nutria por ele. Nesse período, aparece ainda o adulto significativo - o dono do bar - e surgem os primeiros vínculos de cunho afetivo-sexual. Namora uma garota a qual engravida e tem o filho. Fernando mantém contato com a criança por seis meses. Tem uma atitude positiva em relação ao filho. "Eu senti como uma vitória muito grande e foi aí que eu vim acordar mais pra vida, d'eu sair desse mundo”. Depois, a família da 
mãe da criança leva os dois para outra cidade, pois a avó do menino não aceita o pai nem o dinheiro do crime. O que Fernando achou disso? "Eu achei uma atitude muito boa, o que ela fez; mas achei um pouco errado por ela ter criticado; se a pessoa roubar pra lá e comprar uma roupa pra uma criança não vai acontecer nada de mal porque quem está fazendo o mal não é a criança.” Já pediu à família para procurar o filho em outra cidade, porém, até hoje não obteve notícias. O vínculo com o filho é, portanto, frágil, não presencial. E, apesar do impacto inicial, a presença do filho em sua vida não se revelou propulsora de mudanças efetivas.

Em seguida, Fernando se envolve com uma garota com quem vai estabelecer uma relação afetivo-sexual significativa. Moram juntos por um ano. Considera-a uma pessoa muito importante em sua vida, até hoje. "Ela tem até raiva de eu ser desse caminho. Dava vários conselhos pra mim, eu não escutava. É uma pessoa concreta”. Nesse ínterim, Fernando cometeu o delito do qual está sendo acusado e saiu da cidade por um ano. Ao retornar, foi preso. A garota foi visitá-lo na delegacia e faz visitas esporádicas:

Namorado dela eu não considero mais não. Mas eu considero muito amigo dela. Porque a nossa amizade é forte mesmo. Não é mais um namoro, porque ela ficou dois anos em outro lugar... E agora já tem já uns quatro meses que ela veio aí. Mas eu, assim.. eu acho que entre eu e ela há uma amizade muito grande porque ela gosta muito de mim e eu gosto muito dela. É uma amizade muito concreta mesmo. Amizade pura mesmo. [...] Onde eu encontrava com ela era namoro e amizade ao mesmo tempo, pois muitas vezes ela desabafava comigo e eu desabafava com ela os problemas.

É um vínculo duradouro, de apego. Ainsworth (1991), ao discorrer sobre o apego no ciclo de vida, deixa claro que os componentes de apego e cuidado sustentam um relacionamento quando o componente sexual diminui sua força. O apego é duradouro e tende a persistir mesmo depois que o companheiro ou a companheira tenha partido, mesmo quando essa partida tenha sido desejada. Existe uma tendência de sentir falta do parceiro e de sentir-se sozinho. Esse apego, contudo, não foi suficiente para a descontinuidade do envolvimento com o crime.

Até aqui, então, a configuração dos vínculos de Fernando e os significados atribuídos a essas interações em contextos nos quais estão inseridas não possibilitaram a descontinuidade do envolvimento 
com o crime. Fernando vai seguindo, então, nesse caminho e acaba se envolvendo em um delito de homicídio que culmina com sua saída da cidade. Ao retornar, após um período foragido, Fernando é denunciado pelos amigos de infância. Essa denúncia vai se tornar um motivo de mágoa e de ressentimento com os antigos companheiros:

Fomos criado junto. Eu e mais dois. Eram os dois melhores amigos. Aonde nois ia tava junto; um almoçava na casa do outro, dormia na casa do outro. Já era mais de doze anos junto; aquela maior amizade. Aí chegaram e me traíram. Eu mesmo, eu me sinto muito revoltado com isso. Acho que eles não têm a mente e a capacidade de pensar no que é uma pessoa presa.

Na delegacia, onde inicialmente ficou custodiado, sofre três atentados porque ainda não tinha "conceito" ${ }_{5} \mathrm{e}$ atribui todo esse sofrimento à traição dos amigos. Essa passagem não funciona como instrumento de ressignificação dos próprios atos. A prisão rompe os vínculos com os amigos de infância e é a família que ressurge como suporte:

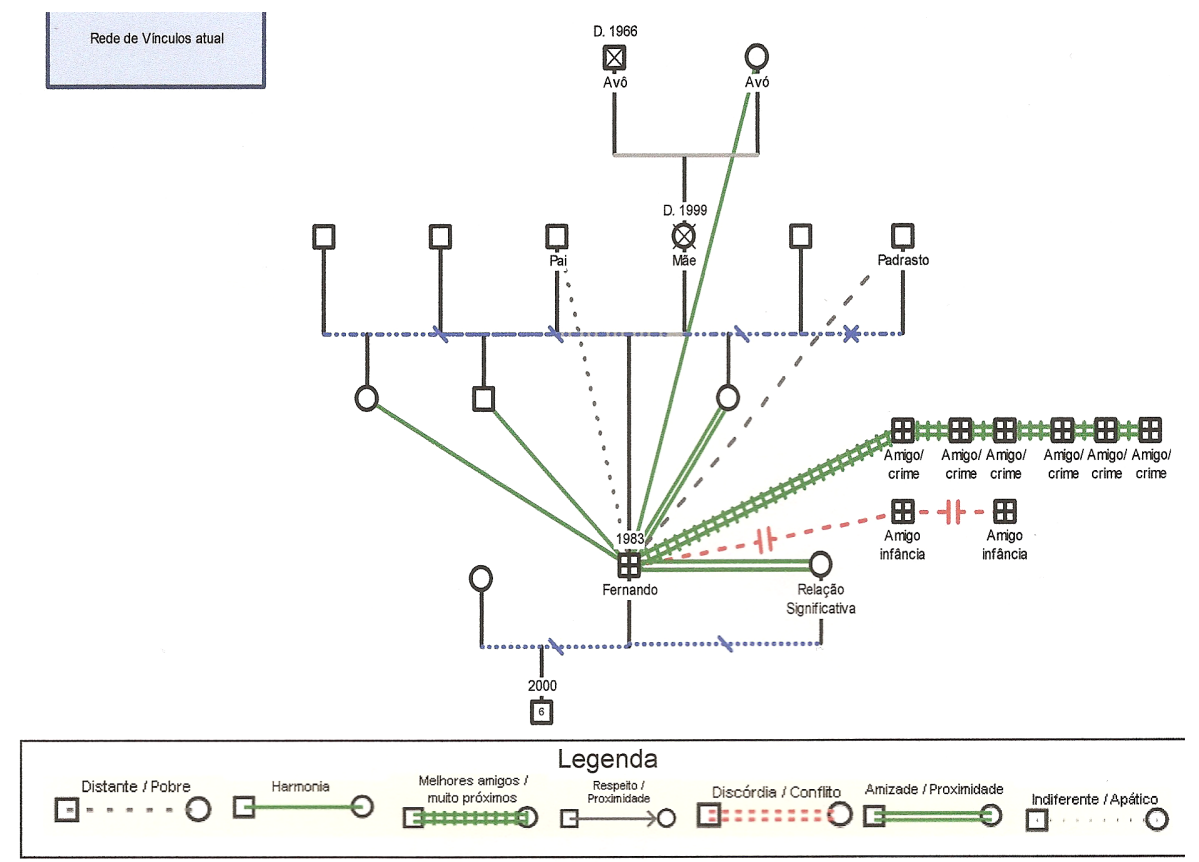

Figura 5 - Rede de vínculos durante o confinamento da prisão Fonte: própria autora

5 Termo que se refere à moral, reputação, consideração. 
A reaproximação da irmã mais velha e o estreitamento do vínculo com a irmã mais nova são observados nesta nova configuração. Os vínculos com os amigos de infância foram interrompidos. Em compensação, foram estabelecidos vínculos com outros pares delituosos que são os companheiros de prisão:

Eles são meus irmãos... Eu trato como meus irmãos, porque os cara não quer saber o que você é, o que você deixa de ser; o que você fez, o que você não fez; os caras só quer saber que você é amigo deles e se você tá correndo com eles.

A solidariedade encontrada no grupo faz com que Fernando valorize os vínculos estabelecidos na prisão, ao mesmo tempo em que reencontra a família e fortalece os vínculos com ela. Quais as consequências dessa nova configuração? Como Fernando supõe este tempo prospectivo? "Só vou poder contar com os meus irmãos, mesmo. Só. Acho que mais ninguém. Só os meus irmãos mesmo e minha vó. Porque não tem uma pessoa pra me ajudar, não tem ninguém. É só minha família mesmo”. Ficam assim, então, as expectativas de vínculos de 90 Fernando:

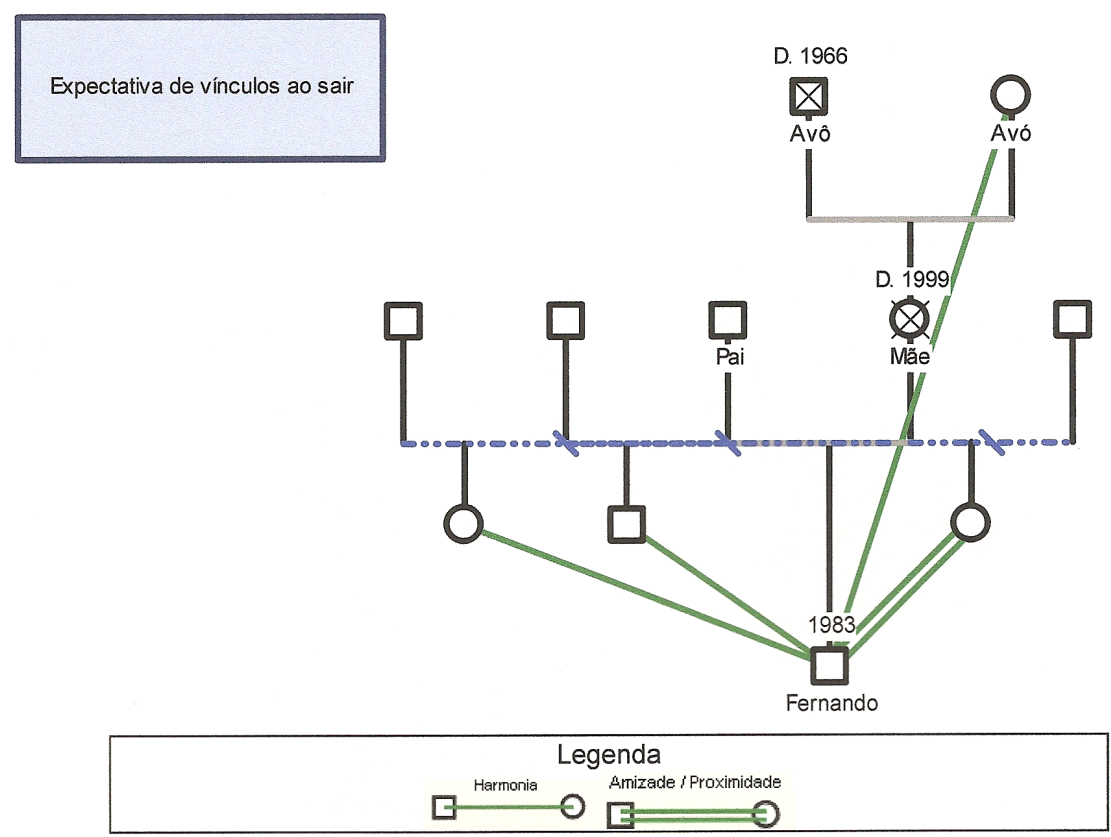

Figura 6 - Expectativa de vínculos de Fernando ao sair da prisão Fonte: própria autora 
A rede de vínculos apresentada por Fernando no decorrer da sua trajetória é caracterizada pela existência de vínculos fortes com seus pares, moderados com sua família e adultos significativos e frágeis com seu filho. No momento da construção dos dados, os vínculos com a família estavam em processo de fortalecimento. A maioria dos vínculos apresenta bi-direcionalidade, isto é, os atores envolvidos mantinham com Fernando a mesma qualidade de vínculo que ele. Os contextos de desenvolvimento são restritos: nota-se o microssistema da família nuclear, do grupo, da escola e da prisão. No entanto, não foram percebidas interconexões entre esses ambientes através de pessoas que transitassem por mais de um espaço, possibilitando a troca de informações e intervenção. É uma rede pequena e a homofilia é percebida na presença de outros autores de delitos. $\mathrm{O}$ contexto socioeconômico parece interferir na restrição dos ambientes, mas não justifica a ausência de outros familiares, de outras instituições e da interconexão entre os microssistemas. Essa restrição e a homofilia - que perdura na sua passagem pela prisão - podem contribuir para a continuidade no crime caso não ocorram mudanças nessa configuração, segundo o modelo utilizado nesse trabalho.

\section{Conclusão}

O autor de delito ora estudado, bem como os demais da investigação original, é protagonista do que usualmente chamamos de street crime na literatura internacional (ALLEN, 2005; DIMASCIO, 2004) ou "criminalidade de rua" na literatura nacional (NORONHA; MACHADO, 2002): ele é pobre, pratica em geral delitos como roubo, assalto e vandalismo, e pode ou não ser usuário de drogas ilícitas.

Retomando a questão do contexto, podemos dizer que cada sociedade, cada momento histórico fabrica seus próprios desviantes. Young (2002) classifica as sociedades como antropofágicas ou antropoêmicas a partir do modo como lidam com esses desviantes: engolindo-os, incluindo-os e tornando-os seus ou vomitando-os, conservando-os fora da sociedade, excluindo-os, comparando essas sociedades, assim, com os processos de canibalismo e bulimia. Considera, assim, que o mundo moderno tanto ingere quanto ejeta; é excludente e includente. $\mathrm{O}$ autor afirma que o mal-estar nas sociedades da modernidade recente não é 
produto da simples exclusão, mas um processo bulímico de inclusão e exclusão: inclui o indivíduo através dos meios de comunicação que dita os padrões de consumo e o exclui quando não proporciona a possibilidade de atingir esses padrões. Como diria Bauman (1998, p. 24), são "consumidores falhos", isto é, "pessoas incapazes de responder aos atrativos do mercado consumidor" e, ainda, impedidos de freqüentar os templos consumistas. Aqueles que não recuam diante da impossibilidade do consumo vão em busca da uniformidade com o outro que é visto como consumidor competente e, para tal mister, passam por cima das leis instituídas. "[...] eles não são mais do que entusiastas da pós-modernidade, aprendizes vorazes e devotos crentes da revelação pós-moderna, ávidos por levar as receitas de vida sugeridas por aquela lição até sua conclusão radical”. (BAUMAN, 1998, p. 26)

O autor de delitos cuja história foi aqui analisada toca exatamente nesse ponto quando menciona sobre o que o fez se manter no crime: "mostrar que tem poder" através do comportamento ou dos resultados conseguidos com o delito. O “poder”, em nossa sociedade pós-moderna, 92 é representado pelo consumo, pela velocidade com que o indivíduo adquire as novidades, pela forma com que descarta bens e pessoas. Mas, certamente, é vago e inútil responsabilizar a "sociedade" pelos atos desviantes, pois isso equivaleria a adotar uma visão passiva do sujeito. Minayo no Prefácio do livro de Assis (1999, p. 11) aponta a necessidade da visão dialética entre o indivíduo e seu meio para que possamos compreender que nenhuma escolha humana é explicada apenas por determinismos sociais apesar de que sejam realizadas a partir das condições dadas.

Notamos na fala do autor de delitos, por outro lado, uma autoculpabilização que revela pouca reflexão sobre esse enredamento existente entre indivíduo e sociedade. DiMascio (2004), ao perguntar a um interno na Prisão Grateford de segurança máxima na Pensilvânia, sobre o motivo pelo qual alguns deles passam anos na prisão e imploram para serem liberados e, depois, rapidamente se envolvem em problemas e voltam para prisão, obtém a resposta. "Eles não sabem como agir diferente. Fazem o que a cultura ensina. Não sabem o que é desafiar a cultura da rua”. Responderíamos da seguinte forma à pergunta de DiMascio: do nosso ponto de vista, a rede de vínculos que o indivíduo estabelece pode limitar ou ampliar suas possibilidades de experiências 
e de aprendizados e pode permitir escolhas e estabelecer controles. Ele pode fazer diferente se houver a possibilidade de fazê-lo. Como dito anteriormente, essa rede vai se reconfigurando na medida em que vínculos são celebrados, fortalecidos ou são desfeitos, enfraquecidos, sem haver, necessariamente, uma sequência causal.

Vê-se que nenhum dos vínculos, isoladamente, nos leva a uma compreensão do envolvimento do indivíduo no comportamento delituoso. O entrelaçamento entre os vínculos, a forma como estão organizados facilitam ou dificultam esse envolvimento conforme previsto no nosso modelo teórico. Por sua vez, a instalação do comportamento delituoso interfere na rede de relações e vínculos estabelecidos pelo indivíduo, reorganizando-a: restringe alguns tipos de vínculos e amplia outros. Essa rede também se caracteriza por ser dinâmica, pois os eventos no curso da vida vão modificando-a. A própria prisão, no caso de Fernando, foi um acontecimento crucial para a retomada de vínculos parentais e familiares.

Diante dos dados coletados, algumas indicações de atuação podem ser pensadas como, por exemplo, nas políticas de acompanhamento de egressos no sentido de implantação de programas que visem à ampliação das redes nas diversas dimensões da vida da pessoa - ação plenamente justificada pelas contribuições de Bronfenbrenner e corroboradas nesse trabalho - ou, ainda, no curso do período de reclusão possibilitar o resgate e fortalecimento de vínculos que contribuam para uma reinserção social que propicie a descontinuidade do comportamento delituoso.

\section{Referências}

AINSWORTH, M.D.S. Attachmente and other affectional bonds across the life cycle. In PARKES, C.M.; STEVENSON-HINDEN, J; MARRIS, P. Attachment across the life cycle. Routledge: London, 1991.

ALLEN, C. The Links Between Heroin, Crack Cocaine and Crime: where does street crime fit in? British journal criminology, v. 45, p. 355-372, 2005.

ASSIS, S. G. Traçando caminhos em uma sociedade violenta: a vida de jovens infratores e de seus irmãos não-infratores. Rio de Janeiro: FIOCRUZ, 1999. 
BASTOS, A.C.S., CARVALHO, A.M.A., RABINOVICH, E.P. \& SAMPAIO, S.M.R. Vínculos e redes sociais em contextos familiares e institucionais: uma reflexão conceitual. Psicologia em Estudo, v. 11, n. 33, p. 589-598, 2006.

BAUMAN, Z. O mal-estar da pós-modernidade. Rio de Janeiro: Jorge Zahar Editor, 1998.

BECKER, H. Outsiders: studies in the sociology of deviance. New York: The Free Press, 1966.

BOWLBY, J. Apego. São Paulo: Martins Fontes, 1984.

BRASIL. Decreto-lei n. 2.848, de 7 de dezembro de 1940. Código penal. Brasil, 1940.

BRASIL. Lei N. 8.072, de 25 de julho de 1990. Dispõe sobre os crimes hediondos, nos termos do art. $5^{\circ}$, inciso XLIII, da Constituição Federal e determina outras providências. Brasília, DF, 1990. Planalto.gov.br.

Disponível em: <http://www.planalto.gov.br/ccivil_03/leis/L8072compilada. htm> Acesso em: 23 jan. 2006.

BRONFENBRENNER, U. A ecologia do desenvolvimento humano: experimentos naturais e planejados. Porto Alegre, RS: Artes Médicas, 1996.

BRONFENBRENNER, U. Context of Child Rearing: problems and prospects. American psychologist, v. 34, n. 10, p. 844-850, 1979.

BRONFENBRENNER, U. Ecology of the family as a Context for Human Development: research perspectives. Developmental psychology, v. 22, n. 6, p. 723-742, 1986.

CARVALHO, A. M. A. Em busca da natureza do vínculo: uma reflexão psicoetológica sobre grupos familiares e redes sociais. In: PETRINI, J.C.; CAVALCANTI, V.R. (Org.). Família, sociedade e subjetividades: uma perspectiva multidisciplinar. Petrópolis, RJ: Editora Vozes, 2005, p. 183-194.

DIMASCIO, W. M. Reflections: Ending the culture of street crime. The prison journal, v. 84, n. 4, p. 428-478, 2004.

GARLAND, D. Discursos sediciosos: crime, direito e sociedade. Rio de Janeiro: Editora Revan, 2002.

HARRIS, J.R. Diga-me com quem anda... Rio de Janeiro: Objetiva, 1999.

HIRSCHI, T. Una Teoría del Controle de la Delincuencia. Capítulo criminológico, v. 31, n. 4, p. 5-31, 2003.

KEHL, M.R. Em defesa da família tentacular. In: GROENINGA, G.C.; 
PEREIRA, R.C. (Org.) Direito de família e psicanálise: rumo a uma nova epistemologia. Rio de Janeiro: Imago, 2003.

NEDER, G. Ajustando o Foco das Lentes. In: KALOUSTIAN, Sílvio Manoug (Org.). Família, a base de tudo. 4. ed. São Paulo: Cortez, Brasília, DF: UNICEF, 2000.

NORONHA, C.N. \& MACHADO, E.P. Pelos Filtros de Circe: violência, insegurança e controle social na mídia impressa. Espacio abierto, v. 11, n. 4, p. 639-663, 2002.

OETTING, E.R.; DONNERMEYER, J.F. Primary Socialization Theory: the etiology of Drug Use and Deviance. I. Substance use \& misuse, v. 33, p. 995-1026, 1998.

PAPALIA, D. E.; OLDS, S. W. Desenvolvimento humano. 7. ed.. Porto Alegre, RS: Artes Médicas Sul, 2000.

REIS, J.R.T. Família, Emoção e Ideologia. Apud Lane, S.T.M e Codo, W. Psicologia social: o homem em movimento. 2 ed. São Paulo: Brasiliense, p. $99-124,1985$.

ROSSETI-FERREIRA, M.C.; AMORIM, K. S., SILVA. Rede de Significações: alguns conceitos básicos. In: ROSSETI-FERREIRA, M.C.; AMORIM, K.S; SILVA, A.P.S.; CARVALHO, A.M.A.(Org). Rede de significações e o estudo do desenvolvimento humano Porto Alegre, RS: Artmed, 2004. p. 23-34.

SILVA, R.C.O. A porta entreaberta. Práticas e representações em torno das relações entre casa e rua junto a crianças de camadas populares em Florianópolis. 1998. Dissertação (Mestrado) - Centro de Filosofia e Ciências Humanas, Universidade Federal de Santa Catarina, 1998.

WIEVIORKA, M. O novo paradigma da violência. Tempo social - revista de sociologia da USP, v. 9, n. 1, p. 5 - 41, 1997.

YOUNG, P. Canibalismo e Bulimia. A Sociedade Excludente: exclusão social, criminalidade e diferença na modernidade recenteRio de Janeiro: Revan , 2002. p. 91 - 143. (Col. Pensamento Criminológico, v. 7) 


\section{Na frente das grades: uma pesquisa com agentes penitenciários da região metropolitana de Belo Horizonte}

Luiz Claudio Lourenço

\section{Introdução}

A questão prisional em Minas Gerais vem ganhando cada vez mais espaço dentro das discussões sobre segurança pública, seja no governo ou na mídia. Esta notoriedade é dada, sobretudo, pelas dimensões crescentes do sistema prisional mineiro. No estado, de 2003 a 2009, o número de vagas do sistema penitenciário mais que quadruplicou, passando de 5.383 para 23.199 mil. O contingente de pessoas presas é maior que a população de $86,6 \%$ dos municípios mineiros, dado que 739 dos 853 municípios do estado tem menos que 46 mil habitantes ${ }^{1}$. O gráfico abaixo apresenta a evolução do sistema prisional em Minas de 2003 a 2009. Para vigiar e manter a ordem deste enorme sistema, o número de agentes penitenciários passou, neste período, de 650 para cerca de 10.461. São estes homens e mulheres o universo de nossa pesquisa.

1 Dados oriundos do IBGE 
Gráfico 1 - Evolução da População Carcerária de Minas Gerais (2003-2009)

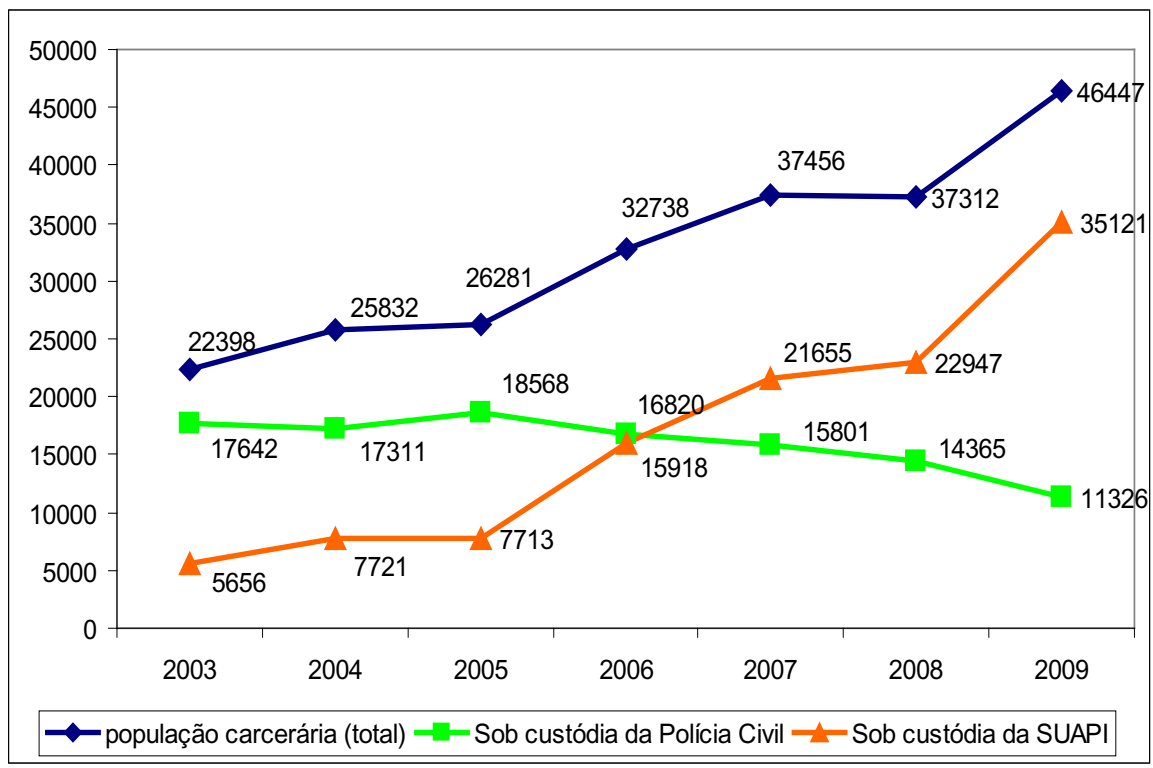

Fonte: InfoPen e Fundação João Pinheiro

O trabalho aqui em tela é fruto, sobretudo, do convívio de sala de aula com cerca de 100 agentes penitenciários da região metropolitana de Belo Horizonte - área que concentra 20 das 98 unidades prisionais de Minas Gerais - durante o ano de 2008. Na dinâmica das aulas de Sociologia das Organizações, estes agentes me chamaram atenção para uma série de questões acerca de sua ocupação, relatando diversas situações tanto de seu dia-a-dia profissional quanto pessoal. Estas questões inicialmente trazidas em aula me motivaram a fazer uma pesquisa mais profunda, para além das anotações que já fazia desta convivência. Para compreender melhor o universo dos agentes parti para obtenção de dados qualitativos e quantitativos sobre eles. Estes dados foram especialmente importantes para a validação e resignificação da observação direta e do convívio em aula. ${ }^{2}$

2 Quero aqui expressar meus agradecimentos a todos os que foram meus alunos no curso de Gestão de Segurança Prisional e também à Profa. Sheila Venâncio, que coordena este curso. 
No que se refere à investigação qualitativa, foi feito um diário de campo por cerca de 25 destes agentes. ${ }^{3}$ Este diário dava conta de uma semana de suas atividades cotidianas, tanto no trabalho quanto fora dele. Embora estes diários pudessem potencialmente representar uma fonte muito rica de informações, muitos dos agentes preferiram retratar seus afazeres da maneira mais impessoal possível, não propiciando assim uma análise mais profunda das relações entre este ator social e seu papel. ${ }^{4}$ Os dados quantitativos foram obtidos através de um survey feito com 91 funcionários do sistema prisional, com questões que abarcaram a relação destes com a lei, sua vitimização criminal, a relação de confiança em instituições, a punição de crimes, além de variáveis de classificação política e social. Todos os dados foram obtidos no interior do Centro Universitário de Belo Horizonte - UNI-BH, um local não associado com o ambiente de trabalho dos agentes e no qual eles puderam se expressar de forma mais livre, tanto formal quanto informalmente. As dificuldades de obtenção de uma amostra probabilística justificaram aqui a coleta dos dados com este grupo de agentes que freqüentavam as aulas. Esta modesta contribuição empírica nem de longe esgota a discussão das dimensões que envolvem o cotidiano do trabalho carcerário, antes esboça um panorama geral e levanta as possíveis questões acerca da influência da vivência carcerária nos agentes.

O grupo estudado, no survey, dividiu-se em 72\% de homens (66) e 28\% de mulheres (25), sendo a maioria católica 51,6\% (47) oriunda da escola pública no ensino fundamental 93,1\% (81) e médio 77\% (67). A idade média dos pesquisados era de 34,7 anos (tendo o mais velho 60 anos e o mais novo com 23), e a média de tempo de serviço de 6,2 anos (tendo o mais veterano 23 anos de prisão e o mais novato 1 ano), sendo que cerca de $22,4 \%$ tinham mais de 8 anos dentro da prisão. Os gráficos abaixo mostram mais em detalhe estas características etárias e de tempo de serviço.

3 Embora a maior parte destes diários sejam de agentes que trabalham no sistema prisional, há também casos de agentes que trabalham no sistema sócio-educativo.

4 Esta maneira objetiva e impessoal já é em si mesma uma informação relevante sobre o mundo prisional que preza discrição e o sigilo. 
Gráfico 2 - Histogramas com idade e tempo de sistema prisional da amostra

*Fonte: elaboração própria
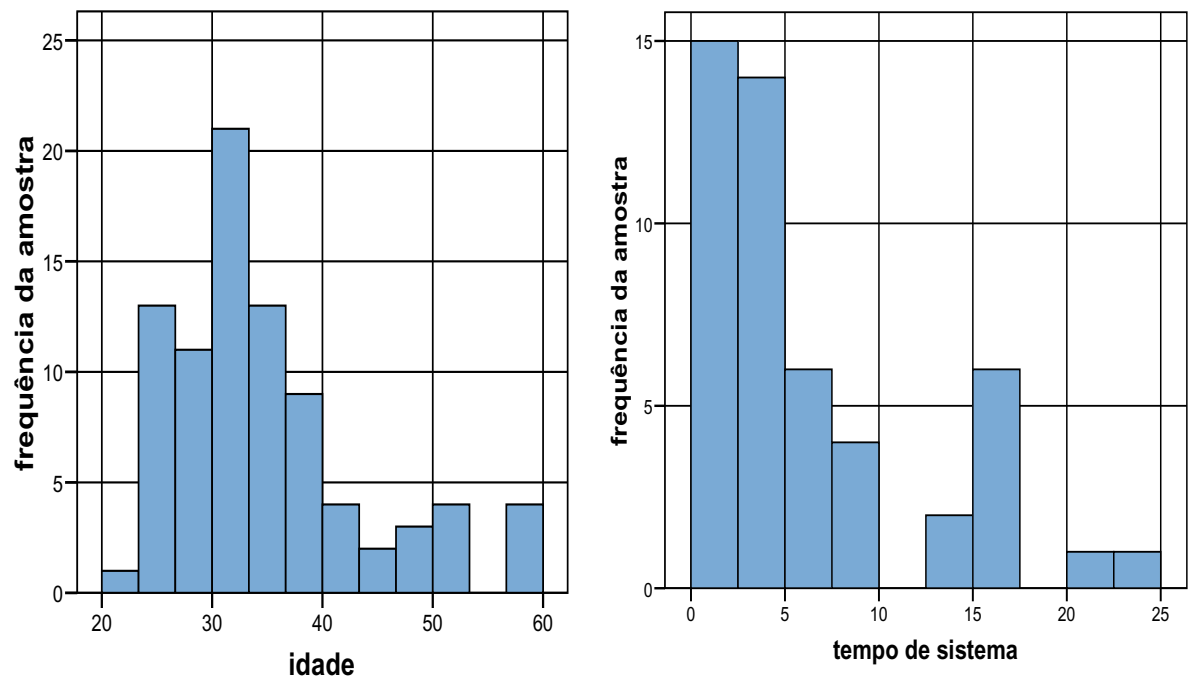

A seguir, partindo da literatura sobre estudos prisionais, vamos discutir alguns aspectos acerca do trabalho no cárcere e o estigma dele proveniente. Posteriormente, com base em nossos dados, será apresentada uma análise mais detalhada sobre algumas das privações cotidianas das dimensões intramuros e extramuros dos agentes. Por fim, apontaremos sucintamente alguns aspectos institucionais sobre o campo profissional dos agentes penitenciários.

\section{A indesejável tarefa de bater a tranca}

Trabalhar no sistema penitenciário é comumente retratado de forma depreciativa. As notícias que chegam aos portais de internet, telejornais, rádios, jornais e revistas, além das obras cinematográficas e da teledramaturgia reforçam apenas a imagem negativa que a maior parte das pessoas tem sobre o trabalho carcerário, sobretudo da ocupação de agentes penitenciários. A lógica de transformar em notícia aquilo que foge da normalidade pouco valoriza o trabalho regular de centenas de milhares de agentes. ${ }^{5}$

5 Não é possível afirmar que o conteúdo destas matérias sejam falsas. Aqui não pretendemos 
A sociedade nunca valorizou ou remunerou muito bem os responsáveis por cuidar e vigiar dos seus indivíduos indesejáveis. O carcereiro (desígnio muito mais comum que agente segurança penitenciário, para o senso comum), no imaginário coletivo, é associado com uma das mais indesejáveis ocupações. Visto como alguém pronto a se corromper, a participar de atividades ilegais, tanto com os presos como com staff do prisional. $\mathrm{O}$ agente ainda carrega a desonrosa fama de torturar e de castigar sadicamente aqueles que não se submetem as suas vontades. A imagem que acaba por permanecer é a de um profissional sem muita instrução e desprovido de qualquer sensibilidade. Essas noções pejorativas sobre o ofício de cuidar do cárcere não se restringem à sociedade brasileira, mas são generalizados como apontam trabalhos sobre agentes penitenciários em outros países. (KAUFFMAN, 1988)

Pode-se classificar, por diversas razões, a categoria de agente penitenciário como a de uma ocupação arriscada e estressante. Este trabalho pode levar a distúrbios de várias ordens, tanto físicos quanto psicológicos; estudos comprovam que a incidência da síndrome de burnout é mais recorrente entre agentes penitenciários. (PEREIRA, 2002; CORREIA, 2006). O risco e a vulnerabilidade são inerentes às características do trabalho no cárcere. Não é por acaso que vários dos esforços de pesquisa, dos últimos anos, sobre esta categoria se concentram, na área da Saúde Coletiva e na Psicologia. (VASCONCELOS, 2000; FERNANDES et al., 2002; KUROWSKI; MORENO-JIMENEZ, 2002; CORREIA, 2006)

Embora o estigma do trabalho carcerário possa não necessariamente marcar o corpo físico, ele invariavelmente afeta a vida dos indivíduos no que se refere às suas possibilidades de interação social, impondo padrões próprios de comportamento e sociabilidade. A categoria de agente penitenciário é sociologicamente tida como desacreditável. É dizer que no momento que o agente passa a ser reconhecido como tal ele também passa a portar o estigma. A identificação com o trabalho carcerário traz também a incorporação e visualização social do estigma decorrente dele. (GOFFMAN, 1963)

negar fatos ou evidencias de existirem funcionários péssimos dentro das prisões. Fica patente que existem problemas relacionados a criminalidade dentro do funcionalismo carcerário, mas aqui, este não é o foco. Acreditamos que embora as notícias sejam verdadeiras elas pouco contribuem para o combate das dificuldades inerentes ao trabalho carcerário e acabam por padronizar uma imagem negativa atribuída ao agente prisional no imaginário coletivo. 
Há duas dimensões importantes nas quais devemos prestar atenção nesta profissão uma interna, dentro dos muros do presídio, que se relaciona com a "sociedade dos cativos" (SYKES, 1958) à qual aqui chamo de intramuros, e outra externa, que se relaciona com a sociedade de uma maneira mais geral, e que designarei como extramuros.

Segundo Moraes (2005), a percepção que o agente tem sobre o estigma que a sociedade lhe dirige pode ser compreendida dentro de uma lógica que transforma o agente em "capeta" e o condenado em "anjo", havendo assim uma inversão da representação moral dos valores no interior dos presídios:

[...] para a sociedade, eles seriam, em primeiro momento, semelhantes aos detentos, e no limite, piores que aqueles. Além de tudo, os agentes não se sentem contemplados e defendidos pelos discursos e políticas de direitos humanos, que, para a maioria deles, continuam sendo 'coisa pra bandido'. [...] Tudo se passaria como se, no interior do sistema penitenciário, houvesse uma inversão de valores e os bandidos e 'maus' passassem para o lugar das vítimas, perseguidas, agora, pelos agentes penitenciários, seus satanizados algozes. Aliás, certa vez falou-nos um agente penitenciário: 'o interno atravessa a cadeia e passa de leão a anjo [...] é a metamorfose do detento. (MORAES, 2005, p. 54-55)

A passagem do castigo físico (submissão corpórea) para o encarceramento (submissão psicológica) também marcou a passagem da figura do carrasco para o carcereiro. Foucault (1995) nos mostra com detalhes como a passagem do castigo do corpo para a submissão e "reeducação social" é fundamental para definirmos também as relações de poder que se estabelecem na sociedade contemporânea. É importante notar que nesta passagem de papéis e transformações de contextos a designação da responsabilidade de executar as penas socialmente estabelecidas permaneceu como sendo função dos funcionários do cárcere. Tanto carrascos, como guardas e mais tarde agentes penitenciários, representam a última barreira de contato social e a mão do Estado na aplicação das sentenças. Com a modernização das prisões as tarefas de controle e punição se diluíram entre a burocracia, em seus vários níveis, mas cabe ainda ao agente a última forma de controle sobre o prisioneiro.

Vale lembrar que o carrasco tinha o artifício do capuz, que lhe cobria a cabeça, e assim preservava parte importante de sua identidade. Isso podia lhe garantir anonimato público e também em relação 
aos condenados. Quem lida com os presos hoje pode ser reconhecido por eles não apenas por uniformes, mas por seus rostos e nomes. Este reconhecimento se dá tanto dentro quanto fora dos muros das prisões. Portanto, ao contrário do que poderíamos imaginar, a "modernização das prisões" não tornou necessariamente mais impessoal a aplicação das penas, e parece ter personalizado mais os antagonismos colocando prisioneiros de um lado e funcionários do cárcere, sobretudo agentes, de outro.

No Brasil a dimensão contemporânea desta dicotomia entre agentes e internos é bem detectada por Coelho (2005, p. 108), que num trabalho pioneiro sobre o sistema prisional, no início da década 1980, afirmava que "[...] efetivamente o guarda (agente) representa e simboliza tudo o que oprime o preso, ou tudo que o preso experimenta, como negligência, frustração, carência, e opressão.” Este quadro nos fornece um caráter duplo ao estigma atribuído ao agente e demais funcionários do sistema prisional. Se para a sociedade em geral ele é desacreditável, para quem é interno do sistema prisional ele é desacreditado. Ele é explicitamente reconhecido através de sua identificação institucional como um inimigo com quem o interno forçosamente deve ter contato e conviver em algum grau. Isso faz com que o agente carregue um estigma duplo, no seu cotidiano extramuros e na sua vida intramuros. Para a sociedade, de uma maneira geral, ele passa a ser visto de maneira estigmatizada quando se descobre seu ofício e no cárcere ele é explicitamente estigmatizado e visto antes de qualquer coisa como um indivíduo indigno que merece desprezo e inimizade.

\section{A dimensão e a vida intramuros}

As mudanças sofridas pelos indivíduos condenados no interior das instituições carcerárias foram descritas e muito bem trabalhadas sociologicamente por vários autores como, por exemplo, Clemmer (1940), Goffman (2005) e Foucault (1995). Mas quero aqui fazer uso da contribuição de Gresham M. Sykes (1958) para o tema do encarceramento e propor o uso de alguns dos conceitos deste autor como ferramenta para análise dos agentes penitenciários.

Em The Society of Captives, Sykes (1958) faz um estudo de caso analisando uma prisão de segurança máxima (New Jersey State Prison) 
e desconstrói uma série de noções idealizadas sobre a prisão. Um dos seus principais achados neste trabalho foi a constatação da necessidade de estabelecimento de relações de convivência mais flexíveis e concessões entre o staff da prisão e alguns prisioneiros em prol de um fim comum: a manutenção da ordem interna. A manutenção da ordem é vista como necessária pelos internos, pois é condição para a continuidade da divisão de poder entre os grupos de presos e suas lideranças. Para o autor, a manutenção da ordem e o confinamento são, nessa ordem, as tarefas de maior prioridade dentro de uma prisão. A punição e a regeneração seriam preocupações de terceira e quarta ordem, respectivamente.

Sykes (1958), relatando as dores do aprisionamento infligidas aos condenados, aponta cinco privações que os internos têm dentro dos muros do presídio: 1) privação de liberdade; 2) privação de bens e serviços; 3) privação de relações heterossexuais; 4) privação de autonomia e 5) privação de segurança. Acreditamos que estas privações - com exceção da privação de relações heterossexuais - também valem para quem vigia os presos. A seguir, partindo desta tipologia, descrevemos algumas das dores do aprisionamento referidas a agentes penitenciários.

\section{A privação de liberdade e a falta de autonomia (o formal e o "jeitinho")}

$\mathrm{O}$ agente ao ingressar dentro de um presídio, mesmo que por turnos determinados, fica isolado de seu convívio social. O contato com familiares é muito restrito durante os turnos de trabalho e mesmo os telefonemas só podem ser feitos em caráter emergencial e por pouco tempo.

Uma outra faceta da privação da liberdade se refere ao horário de serviço. A hora para ingresso é, e deve ser, rigorosamente cumprida. Contudo, quando acontece algum incidente e o agente tem que permanecer com a escolta de um preso nem sempre a hora de saída dos turnos é respeitada, como é o caso que relata o diário do agente C.

Na parte da tarde ocorreu uma briga generalizada entre os detentos durante o banho de sol, onde um deles recebeu alguns golpes de chucho (uma espécie de faca) e tivemos que encaminhá-lo até um hospital de Venda Nova [...] permaneci ali até às $19 h 40$ esperando 
a chegada e outra equipe de agentes que faria o rendimento, pois o detento iria ficar internado. (C. 27 anos)

Esta privação ganha mais expressividade quando se acrescenta uma inversão da lógica institucional de vigilância. Ao contrário do pretendia a engenhosidade de Jeremy Bentham as prisões não funcionam como um panóptico ideal, na prática elas operam como um panóptico invertido. Os agentes são muito bem vigiado pelos internos que tiram proveito dos padrões regulares de ações adotadas. "Eles prestam atenção em tudo, tão sempre de olho. Qualquer vacilo pode ser fatal, no sistema a gente tá sempre no fio da navalha." relata R. (30 anos).

Este quadro nos dá outra dimensão de suas privações: a falta de autonomia. Boa parte dos movimentos dos agentes dentro do cárcere é vigiada. Além disso, a rotina institucional e determinações, aquém da vontade do agente, não abrem possibilidades de que ele coloque formalmente suas próprias vontades como alternativas de ação institucional. Seus afazeres são padronizados e a maioria segue uma ordem prescrita, algo típico de instituições totais. (GOFFMAN, 2005)

É importante dizer que esta falta de autonomia é mais aparente e se manifesta com maior intensidade nas atribuições formais. Informalmente, os agentes podem substantivamente influenciar a dinâmica da prisão e garantir rigor para alguns internos ou até privilégios para aqueles presos que lhe interessarem. $\mathrm{O}$ relato de um agente sobre um colega que acabou sendo preso por bater na companheira é bem ilustrativo:

Nós sabíamos que se não fizéssemos nada ele ia estar pegô no xadrez [sic], porque ele ia para lá. Os presos não iam ter dó, imagina a chance de pegar um agente, ainda mais que bateu em mulher. Então a gente fez que fez, conversou com o diretor e tal pra não deixar ele junto com os outros (presos). Se não desse um jeitinho, aí ele tava morto. (R. 49 anos)

Isso mostra uma ambiguidade interessante: por um lado, a restrição da ação institucional do agente, e por outro, a informalidade e flexibilidade de ação na prática prisional. Em outras palavras, se o agente não pode fazer o que acha melhor ou mais funcional pelas regras, ele de alguma maneira tem como fazer isso nas "entrelinhas" da lei. Cerca de mais de dois terços do grupo, 64,4\%, declarou que tanto já havia dado quanto pedido um "jeitinho” para alguém. 
Tabela 1 - Pedir e dar um "jeitinho” para alguém

\begin{tabular}{|c|c|c|c|c|c|c|}
\hline & \multicolumn{4}{|c|}{$\begin{array}{l}\text { Alguma vez já pediu para alguém dar um } \\
\text { 'jeitinho'? }\end{array}$} & \multirow{2}{*}{ Total } \\
\hline & & & $\operatorname{sim}$ & não & $\begin{array}{c}\text { não } \\
\text { lembra }\end{array}$ & \\
\hline \multirow{3}{*}{$\begin{array}{l}\text { Alguma vez já } \\
\text { deu 'jeitinho' } \\
\text { para alguém? }\end{array}$} & $\operatorname{sim}$ & (n) $\%$ & (58) 64,4\% & (2) $2,2 \%$ & (1) $1,1 \%$ & $\begin{array}{r}(61) \\
67,8 \%\end{array}$ \\
\hline & não & (n) $\%$ & (8) $8,9 \%$ & (19) $21,1 \%$ & (0) $0,0 \%$ & $\begin{array}{r}(27) \\
30,0 \%\end{array}$ \\
\hline & não lembra & (n) $\%$ & (0) $0,0 \%$ & (1) $1,1 \%$ & (1) $1,1 \%$ & (2) $2,2 \%$ \\
\hline \multicolumn{2}{|l|}{ Total } & (n) $\%$ & (66) 73,3\% & (22) $24,4 \%$ & (2) $2,2 \%$ & $\begin{array}{r}(90) \\
100.0 \%\end{array}$ \\
\hline
\end{tabular}

Fonte: *Elaboração do autor.

A tabela acima mostra que o grupo se dividiu claramente entre aqueles que pedem e também concedem "jeitinho" e aqueles que não concedem e nem pedem "jeitinho" (Fazendo o teste qui-quadrado encontramos mais de 99,9\% de significância). Este dado indica explicitamente dois tipos de comportamento: um mais estrito na aplicação de regras e outro mais flexível. Outro dado significativo é que cerca $80 \%$ dos pesquisados acredita que a lei deve ser sempre cumprida enquanto que $20 \%$ afirmou que a lei deve ser cumprida apenas na maioria das vezes.

Uma queixa usual, sobretudo de quem já está mais tempo trabalhando no sistema prisional, é que os agentes nunca, ou quase nunca, são ouvidos sobre como a cadeia deveria funcionar ou o que deveria ser feito para que ela funcionasse melhor. Vivenciando de perto a cultura da prisão, os agentes podem, segundo eles, conhecer melhor as chances de sucesso, efetividade e funcionalidade de certos procedimentos a são propostas a serem adotadas. Na percepção dos agentes as autoridades desconhecem e não valorizam quem trabalha no cotidiano prisional. O depoimento da agente G. (26 anos), que tem mais de 10 anos de sistema, deixa isso claro: "O dia que eles perceberem a importância do agente eles iam ouvir mais a gente.” Constatação similar também foi feita por Góes e Makino (2002), analisando presídios no interior paulista, relatam as autoras: "Eles [agentes] reclamam pelo não reconhecimento do seu conhecimento construído através da observação cotidiana dos presos”. (GÓES; MAKINO, 2000, p. 173) 
Um outro aspecto muito expressivo desta privação intramuros é a impossibilidade da livre expressão emocional. O agente que deixa seus sentimentos aflorarem pode facilmente ser visto como fraco pelos colegas e pelos internos. Uma fala comum é que "quando se veste o uniforme, se tira o coração" ou quando se vai para o trabalho, o coração fica em casa. A fala da agente D. (34 anos) mostra como as possibilidades de expressar emoção podem ser interpretadas: “[...] Já teve casos em que eu me identifiquei e quis chorar, mas naquela hora... O que malandro vai pensar?"

Vemos que tanto a incapacidade de ser escutado pelas autoridades da prisão e de poder se expressar emocionalmente no espaço prisional adensam o ranking das privações carcerárias vivenciadas pelos agentes.

\section{A privação de bens e serviços e de segurança}

No que se refere à privação de bens e serviços, algo que provoca certa irritação e "revolta", quando mencionado aos agentes, são os serviços de assistência psicológica e, especialmente, o acesso a educação superior garantida à presos condenados em algumas prisões. $\mathrm{O}$ sentimento de ser preterido diante de um condenado é expresso sem rodeios em queixas, como a do agente A. (26 anos): "Eu pago minha faculdade, mas os caras lá [presos] não. Para eles é de graça!”6 A assistência psicológica também não é um serviço que os agentes com os quais tive contato usualmente pudessem usufruir, sendo voltada apenas aos internos. A fácil comparação, a percepção de desvantagem e o questionamento através da ironia são comuns para qualificar o que consideram privilégios dos presos.

Por outro lado, é interessante notar que as agentes femininas que trabalham no complexo penitenciário Estevão Pinto se orgulham do atendimento dado no berçário destinado aos filhos das presas, onde é possível que após o parto mãe e filho tenham a convivência cotidiana garantida. $^{7}$

6 Vale lembrar que os agentes e demais funcionários do estado receberam uma bolsa que lhes garantiu um desconto de 30 a 40\% no preço das mensalidades do curso de Gestão de Segurança Prisional.

7 As informações objetivas sobre o complexo Estevão Pinto foram obtidas através das agentes 
Durante os turnos, os agentes usam uniformes e nenhum ou quase nenhum, bem pessoal, talvez as únicas exceções sejam relógios de pulso e correntes que não possam ser vistas embaixo das roupas. Todos os pertences são guardados no início de cada turno e retomados ao seu término. Armas de fogo e coletes à prova de balas são obrigatoriamente fornecidos pelas unidades prisionais apenas aos agentes que praticam vigilância e escolta e não podem ser usadas nas suas dependências internas, apenas nos muros, guaritas, etc. (MINAS GERAIS, 2003) Minas demorou muito tempo para regulamentar o porte de arma para agentes penitenciários, até 3 de abril de 2009. ${ }^{8}$ Se o agente estivesse com alguma arma fora do serviço era normalmente enquadrado dentro do crime de porte ilegal de arma. Vale lembrar que desde 2003, já vigora a lei federal 10.826, que permite que agentes possam portar armas; contudo, cada unidade da federação passou a regular este porte através de leis específicas. ${ }^{9}$ Entre os pesquisados 28,6\% (26) possuem algum tipo de arma de fogo em casa.

A falta de segurança é uma das privações mais presentes dentre as infligidas cotidianamente a este profissional. Não são raros os conflitos entre presos, e nestas ocasiões é comum que uma equipe especialmente treinada seja acionada para apartar a situação. Embora exista uma série de procedimentos e medidas de segurança, estes confrontos muitas vezes redundam em danos físicos aos agentes. Além disso, o contato diário com indivíduos agressivos, que muitas vezes fabricam armas brancas e tem disposição para atacar torna a salubridade física algo precária.

Outra situação de exposição extrema ao risco provém das rebeliões. Os funcionários do estado são uma alternativa usual para serem feitos reféns. Nestas ocasiões é comum a intensificação da raiva e a prática de violência contra os agentes. Os rebelados frequentemente espancam, torturam e estocam objetos perfurantes, além de humilharem de

e triangulada por sites. Disponível em: <http://www.eunanet.net/beth/news/topicos/penitenciarias_femininas_noticias_elizabeth_misciasci.htm $>$ e $<$ http://www.agenciaminas.mg.gov. br/detalhe_noticia.php?cod_noticia=13467> Acesso em 17 abril de 2008.

8 A competência para expedição do porte de arma de fogo de uso permitido é da Polícia Federal, conforme art. 10 da Lei n. ${ }^{\circ}$ 10.826/2003, bem como regulamento estabelecido através do Dec. 5.123 , de $1^{\circ}$ de julho de 2004.

9 No caso de Minas Gerais, através do decreto 45.084/2009. 
várias maneiras os seus reféns. ${ }^{10}$ "Fui refém duas vezes, cinco dias na primeira e dois na segunda. Não dormia e só paulada”, revela P. (47 anos, 14 deles de sistema).

Embora a agressão física seja um problema grave sua incidência ainda é muito menor que do assédio e a ameaça, estas parecem fazer parte inexorável do cotidiano da vida intramuros. É interessante notar que entre os crimes sofridos pelos pesquisados o mais freqüente foi justamente a ameaça de morte, sendo que praticamente metade da amostra já havia sofrido este tipo de vitimização 49,5 \% (45). Para se ter uma ideia, na população brasileira, incidência de ameaça de morte girava, em 2002, em torno de 12,8\%. (PESB, 2002) Cruzando esta variável por sexo, observa-se que homens da amostra são mais ameaçados que as mulheres, cerca de 25,4\% (0,254 Phi, com significância 0,017, número de casos válidos de 89). Este é um indício que aponta para condições de trabalho diferenciadas nas unidades prisionais femininas da região metropolitana, as quais apresentam problemas de outras ordens são mais freqüentes. ${ }^{11}$

Tabela 2 - Ameaça de morte por sexo

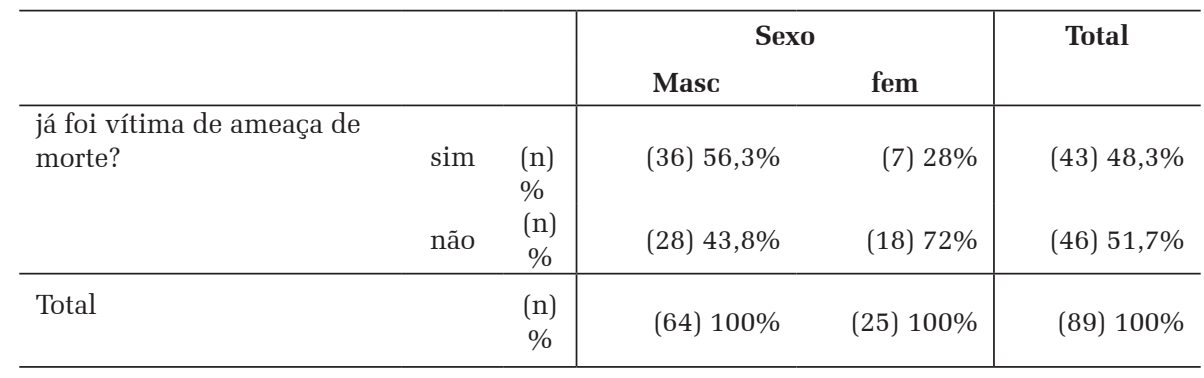

Fonte: Elaboração do autor.

10 Hoje o Estado começa a repensar os danos os quais agentes sofrem nestas ocasiões, uma prova disso é a decisão tomada pelo TJMG que indenizou um agente com R\$ 5 mil por danos morais sofridos em virtude de uma rebelião na penitenciária Nelson Hungria na qual ele foi feito refém por mais de 23 horas. Esta decisão se deu em 2004, 4 anos após a rebelião. Processo: 1.0024.02.630691-0 /001 Disponível em: <http://www.conjur.com.br/2004-set-14/ refem_rebeliao_penitenciaria_indenizacao > Acesso em: 11 maio 2009.

11 Não é o escopo deste trabalho aprofundar as peculiaridades da agente prisional feminina, mas fica aqui registrada estas possíveis diferenças. 
Um dos achados apontados por Coelho (2005) diz respeito ao maior assédio e ameaça ao guarda [agente] novato: “a intimidação é um recurso largamente utilizado pelos presos para testar o guarda [agente] novato.” (COELHO, 2005, p. 100) Testamos esta hipótese no grupo e não observamos nenhuma correspondência ou correlação entre tempo de serviço e ameaça de morte, tanto novatos quanto veteranos sofrem e forma similar ameaças de morte.

\section{A dimensão e as atividades extramuros}

Parte dos agentes e demais servidores carcerários tem uma percepção comum e correta sobre o tempo que passam na prisão, a de que é provável que muitos condenados, dada as características de nossa lei de execução penal, passem menos tempo dentro de uma unidade prisional que qualquer um deles. Hoje, mesmo para crimes hediondos, a progressão da pena pode ser dada tendo-se cumprido menos que a metade do tempo de condenação. ${ }^{12}$ Observando os dados de presos condenados é possível notar que somente a menor parte dos presos no Brasil tem condenações superiores a 30 anos, cerca de 4,93\% e 4,26\% em Minas Gerais, segundo os dados do InfoPen, de junho de 2008, cerca de 53,53\% dos condenados no país tem penas de até 8 anos de reclusão, em Minas este percentual também é expressivo, totalizando 49,1\%. ${ }^{13}$

Isso é um dos motivos que faz com que o agente penitenciário tema por sua segurança e tome cuidado com ela. É o medo o que mais aflige o agente fora dos muros da prisão. Vimos que este temor tem dimensões consideráveis entre os pesquisados, vez que 70,4\% deles já teve alguma dificuldade em dormir porque ficou pensando em violência, 62,7\% já acordou no meio da noite pensando em situações de violência e 64,4\% havia procurado evitar em pensar em violência no mês anterior a pesquisa.

12 Segundo a Lei 11.464, de 28 de março de 2007 que rege a progressão de regime para crimes hediondos estabelece: $\S 1^{\circ} \mathrm{A}$ pena por crime previsto neste artigo será cumprida inicialmente em regime fechado. $\S 2^{\circ}$ A progressão de regime, no caso dos condenados aos crimes previstos neste artigo, dar-se-á após o cumprimento de $2 / 5$ (dois quintos) da pena, se o apenado for primário, e de $3 / 5$ (três quintos), se reincidente.

13 Site do InfoPen MJ, Disponível em < www.mj.gov.br/depen/data/Pages/MJD574E9CEITEMIDC37B2AE94C6840068B1624D28407509CPTBRIE.htm> Acesso em: 17 maio 2009. 
Embora a ameaça de morte seja o crime ${ }^{14}$ mais frequente reportado pelo grupo - sobretudo na dimensão intramuros como relatado por vários deles - não foi o único. Fica claro que este ator aparece como um alvo em potencial da criminalidade urbana. Os dados mostram um padrão de vitimização expressivo, como podemos observar na tabela abaixo:

Tabela 3 - Tipos de crimes sofridos

\begin{tabular}{|l|c|c|}
\hline Você já foi vítima de: & $\begin{array}{c}\text { Grupo Pesquisado } \\
\text { \% }\end{array}$ & $\begin{array}{c}\text { População Brasil (2002)** } \\
\text { \% }\end{array}$ \\
\hline assalto à mão armada & 27,8 & 17,8 \\
\hline roubo por um ladrão sem armas & 28,6 & 24,1 \\
\hline roubo em sua casa & 37,4 & 22,1 \\
\hline tentativa de roubo à sua casa & 34,8 & 26,3 \\
\hline roubo de carro & 22,5 & 10,8 \\
\hline agressão na rua & 11,2 & 11,6 \\
\hline ameaça de morte & 49,5 & 12,8 \\
\hline
\end{tabular}

Fonte: Elaboração do autor com base na PESB: Pesquisa Social Brasileira. (ALMEIDA, 2002)

Além destes crimes, 22\% dos pesquisados também assinalaram a categoria "outros crimes sofridos". Dentre estes foram especificados casos de sequestro relâmpago, calúnia, lesão corporal, racismo, tentativa de estupro, tentativa de homicídio, roubo de som de carro e assalto (sem arma). Estas informações corroboram a ideia de que tanto na vida intramuros quanto na extramuros dos agentes o signo do crime está presente. Há a possibilidade do agente ser vítima tanto no seu trabalho quanto fora dele. Em média, o grupo pesquisado já havia passado por 2,3 crimes. Contudo, como é possível ver no histograma abaixo, mais de um terço $(36,3 \%)$ do grupo foi vítima de mais de 2 crimes, enquanto $14,3 \%$ nada sofreram. ${ }^{15}$

14 Ameaça de morte é crime prescrito no artigo 147 do Código Penal Brasileiro.

15 Também foi testada a possível correlação (R de Pearson) entre tempo de trabalho no sistema prisional e número de crimes sofridos, contudo os resultados não foram significativos. O que mostra que a vitimização não está diretamente associada à ocupação, mas indiretamente. 
Gráfico 3 - Histograma de frequência de crimes sofridos

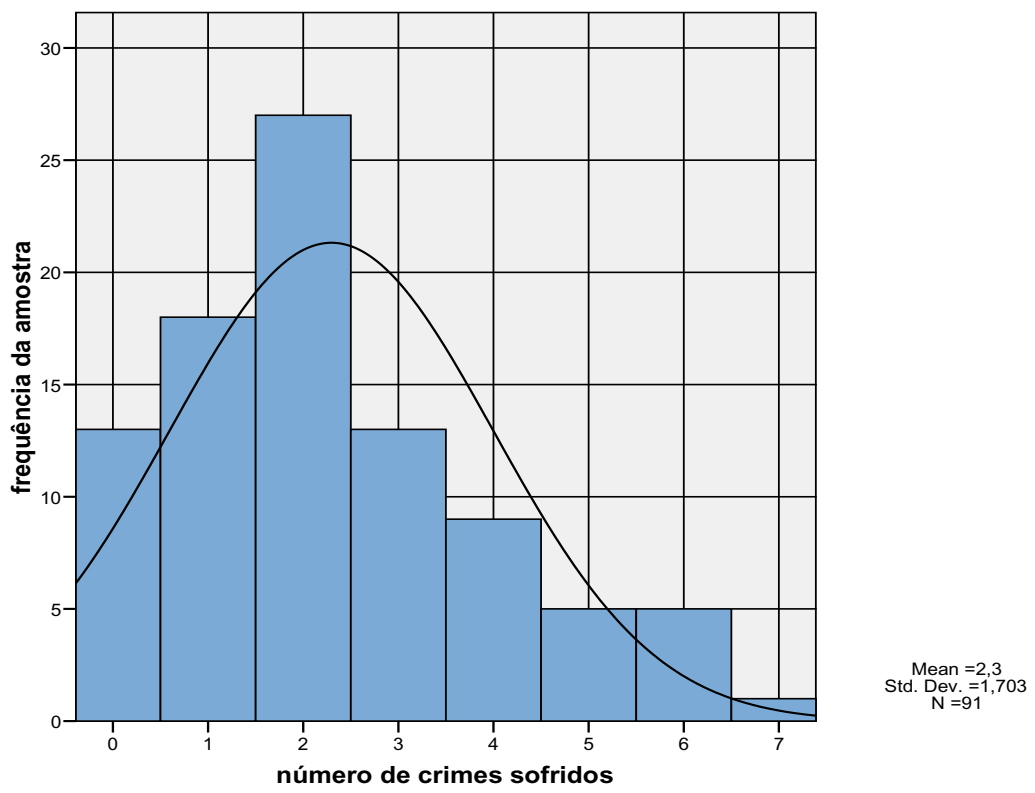

Fonte: Elaboração do autor.

Esta vitimização múltipla pode ser melhor compreendida também pelo estilo de vida e o que este estilo implica, incluindo-se aí o local de moradia. Observa-se que a incidência de crimes que ocorreram nos bairros dos pesquisados, no período dos últimos doze meses que antecederam o survey, é muito alta. Destacam-se aqui a os crimes que envolvem violência física contra as vítimas e incidência de delitos com drogas (consumo e tráfico), como é possível ver com mais detalhes na tabela abaixo. 
Tabela 4 - Incidência de ações criminosas no bairro dos pesquisados

\begin{tabular}{|l|c|c|}
\hline $\begin{array}{l}\text { Se aconteceu no seu bairro nos últimos 12 } \\
\text { meses }\end{array}$ & $\begin{array}{c}\text { Grupo } \\
\text { Pesquisado* } \\
\text { \% }\end{array}$ & $\begin{array}{c}\text { População Brasil } \\
\text { (2002)** }\end{array}$ \\
\hline pessoas que foram assaltadas no seu bairro & 72,2 & 53,8 \\
\hline alguém ser assassinado & 61,4 & 36,7 \\
\hline alguém levar um tiro & 56,8 & 36,7 \\
\hline alguém ser agredido fisicamente & 58,0 & 48,4 \\
\hline pessoa puxar uma arma para outra & 43,8 & 39,6 \\
\hline tráfico de drogas/compra e venda de drogas & 78,9 & 55,7 \\
\hline alguém usando drogas & 80,9 & 65,5 \\
\hline roubo de carros & 50,6 & 37,4 \\
\hline comércio de coisas roubadas no seu bairro & 33,0 & 32,3 \\
\hline casa/aptos foram assaltados no seu bairro & 50,6 & 55,0 \\
\hline
\end{tabular}

Fonte: elaboração do autor com base em PESB 2002

A avaliação da segurança da vizinhança da moradia aponta uma faceta importante da percepção de insegurança extramuros. Nenhum dos entrevistados considera o bairro onde mora muito seguro. As avaliações somadas de pouco e nada seguro alcançam $71,1 \%$ para rua onde moram, $78,9 \%$ para o bairro e $82,2 \%$ para as ruas próximas.

Acreditamos que estes números ainda poderiam ser maiores se não fosse a preocupação constante que o agente tem com sua própria segurança. Este cuidado se expressa não só em serviço, mas em toda sua vida. Certa feita me surpreendeu o grande número de motociclistas existentes entre os meus alunos de gestão prisional. Perguntei então porque eles preferiam moto a automóvel. Eles me responderam que a moto era mais rápida e mais segura, no caso deles. Com capote e calça pretos, sem nenhum tipo de identificação, além do capacete todo negro, eles "passavam batido" (discretamente). Disseram ainda, que era mais fácil encurralar carro que moto. "Na nossa área a gente tem que se cuidar”, me lembrou L. (27 anos).

Outra fala comum entre eles era a de que "quem trabalha no sistema não repete o caminho". Por "questão de segurança", muitos 
diziam que sempre optavam por rotas alternativas nos trechos de deslocamento entre trabalho-residência-trabalho e residência-trabalho-faculdade-residência.

As possibilidades de lazer dos pesquisados também se limitavam mais a opções que não envolviam contato com multidões ou ambientes públicos. Segundo os diários escritos por eles próprios a maioria preferia ficar com suas famílias, namoradas ou amigos quando tinham tempo vago. Dormir, visitar parentes e ver televisão foram as formas de uso do tempo livre mais relatadas. O diário da agente feminina T. (28 anos), narrando o seu fim-de-semana, é um bom exemplo:

Depois do almoço vou descansar um pouco, assistimos um filme e vamos arrumar para ir passear na casa da minha mãe, que fica a quatro quarteirões da minha. Retornamos para casa por volta das 22:00 e vamos deitar e assistir televisão. No domingo tiro parte da manhã para organizar minhas coisas pessoais, como contas, compras e aí vu providenciar o almoço. Às vezes passeamos a tarde e vamos descansar para aguardar a segunda-feira quando a rotina semanal se inicia. Geralmente domingo deitamos após o término do Fantástico. (T. 28 anos)

Percebe-se, neste trecho, uma restrição grande de possibilidades de uso do livre para o lazer. Isso pode ser compreendido em parte pela preocupação com a segurança e em parte pelo cansaço da rotina semanal. As obrigações do cotidiano acabam sendo deixadas para este tempo que passa a não ser mais tão livre.

Outro aspecto importante relatado no cotidiano dos pesquisados são os preconceitos sofridos, $61,8 \%$ afirmou já ter sofrido algum tipo de discriminação. "Trabalhar na cadeia é diferente, o pessoal não é visto da mesma forma. Aqui mesmo na faculdade tem professor e aluno que tem até medo da gente”, me confidenciou ao fim de uma aula o agente M. (23 anos). Já outros agentes me diziam de preconceitos sofridos pela cor da pele, pelo local de moradia e por sua origem social "mais humilde”. Para a compreensão destas discriminações há a necessidade de pensá-las de maneira plural e multidimensional. O trabalho no cárcere acaba sendo uma opção plausível para as parcelas mais marginalizadas e discriminadas da sociedade. (WACQUANT, 2001) As características sociais deste grupo apontam para uma soma de discriminações. A percepção experimentada por estes indivíduos cotidianamente é que, além de ser pobre, morar em um bairro perigoso da periferia, 
e ter a pele escura, eles trabalham na prisão. Neste sentido o estigma de agente penitenciário une com grossas correntes todas estas demais dimensões discriminatórias vivenciadas por este trabalhador.

\section{Algumas notas sobre a profissionalização do agente penitenciário}

Preterido durante muito tempo, apenas recentemente o agente penitenciário começa a ser mais valorizado por parte dos responsáveis pela segurança pública no país. Excetuando São Paulo, que já tem certa tradição na formação de seus agentes, os demais estados aos poucos começam a regular e qualificar melhor a ocupação de agente de segurança penitenciário.

Hoje, já temos cerca de 13 estados com escolas de formação de agentes. Outro dado importante, desta mudança de perspectiva nas políticas públicas, é a estipulação no Plano Diretor do Sistema Penitenciário (2008), de 3 metas (das 22) envolvendo funcionários do sistema penitenciário, 2 especificamente ligadas aos agentes. ${ }^{16}$ (BRASIL, 2008) Também está tramitando no Congresso Nacional a proposta de emenda constitucional, a PEC 308/2004, para criação de um estatuto nacional unificado para o trabalho carcerário com a instituição da polícia penal. Contudo, entre os gestores não há consenso sobre as vantagens desta proposta idealizada por diversos sindicatos de agentes no país. A despeito disso, na última década a instituição da carreira avançou em todo país e também em Minas Gerais.

Em junho de 2003, ficou estabelecida no estado a carreira de agente de segurança penitenciário. Pela lei 14.695 (MINAS GERAIS, 2003), foi criada a profissão com a seguinte redação:

Art. $5^{\circ}$ Fica criada, no Quadro de Pessoal da Secretaria de Estado de Defesa Social, com lotação na Subsecretaria de Administração Penitenciária, a carreira de Agente de Segurança Penitenciário, composta por cinco mil e quatro cargos efetivos de Agente de Segurança Penitenciário.

16 META 11 (AGENTES, TÉCNICOS E PESSOAL ADMINISTRATIVO) - LEP, art. 76 e 77 - Criação de carreiras próprias de servidores penitenciários, e elaboração de um plano de carreira; META 12 (QUADRO FUNCIONAL) - LEP, art. 76 e 77 - Ampliação do quadro de servidores penitenciários. META 13 (ESCOLA DE ADMINISTRAÇÃO PENITENCIÁRIA) - LEP, art. 77 Criação de Escola de Administração Penitenciária. 
Em julho de 2004, também surge o Sindicato dos Agentes de Segurança Penitenciários de Minas Gerais (SINDASP-MG). O sindicato e o estatuto marcaram um avanço ao estabelecer procedimentos adicionais para o exercício profissional, uma maior qualificação e propor um plano de carreira. Nota-se, contudo, que há um descompasso entre o número de agentes em exercício (10.461) e o número que é estabelecido no texto da Lei (5.004). Isso porque a maioria dos agentes penitenciários não era efetiva (concursado) e trabalhava com contratos temporários (com validação semestral). Na prática se criou um ofício comum com dois regimes de trabalho juridicamente diferenciados.

Do grupo pesquisado, 72\% (66) tinha contrato temporário e apenas $28 \%$ (25) eram efetivos. Este problema não se restringe apenas a Minas Gerais, sendo que há outros estados que também operam com servidores temporários. ${ }^{17}$ Observando o tempo de serviço em relação ao regime de trabalho no grupo estudado, vê-se que muitos continuavam há anos (4,2 anos em média) vivendo como trabalhadores temporários, havendo casos de servidores com mais de 10 anos de sistema prisional 116 como provisórios. As incertezas decorrentes da condição de temporário motivavam um grande número de queixas. Este tipo de contrato não garante uma série de ganhos institucionais como prêmio por produtividade, plano de carreira e atendimento hospitalar por mais de 15 dias, por exemplo. Se por um lado, pode-se argumentar que os contratos possibilitam com menos burocracia a substituição de agentes que não desempenhem bem suas tarefas, por outro, também é plausível observar que este regime gera pouco compromisso por parte do servidor que não tem perspectiva de ser efetivado. Novos aprovados em concursos públicos estão gradualmente substituindo os trabalhadores temporários. Esta substituição de temporários por concursados tem se intensificado recentemente e gerado manifestações na categoria. ${ }^{18}$

17 Este é o caso, por exemplo, da Bahia que faz concursos para trabalhadores temporários conhecidos como REDA. O contrato de serviço neste caso é de um ano e meio não sendo renovável.

$18 \mathrm{Em} 1^{\circ}$ de abril de 2009 ocorreu uma grande manifestação na Praça da Liberdade, em Belo Horizonte, reunindo cerca de 3 mil agentes protestando contra as eminentes demissões de temporários, foram quase 9 horas de manifestação. Disponível em: < http://www.otempo.com. $\mathrm{br} /$ noticias/ultimas/?IdNoticia $=37387 \&$ busca $=$ penitenci\%E1rios\&busca=penitenci\%E1rios\& busca $=$ penitenci\%E1rios $>$ Acesso em 09 de maio de 2009. 


\section{Considerações finais}

O interno de uma instituição prisional passa por um processo de institucionalização (CLEMMER, 1940; GOFFMAN, 2005, FOUCAULT, 1995) se despersonalizando por um lado e interiorizando um modo de vida específico à prisão por outro. O agente penitenciário vivencia um processo similar, contudo diferenciado do vivido pelo interno, assimilado de outra perspectiva.

Ao incorporar os riscos inerentes ao trabalho carcerário a sua maneira os agentes sofrem as chamadas "dores do aprisionamento". Neste processo sofrem dentro dos muros privações de: liberdade, de autonomia, de bens e serviços, de expressão de suas emoções, de terem voz na gestão da prisão. Diante destas restrições, os agentes lançam mão de alguns subterfúgios possíveis para transcendê-los flexibilizando as regras pedindo e concedendo "jeitinhos".

As 'dores do aprisionamento’ não se restringem à dimensão ocupacional. Há várias implicações do exercício desta ocupação tanto nas atividades intramuros como no cotidiano extramuros. As principais dizem respeito ao medo da violência, a sensação de insegurança, a vitimização, as restrições de lazer e, sobretudo, o preconceito advindo do estigma do trabalho carcerário. Assim, a influência da prisão na vida de quem trabalha nela não se esgota quando terminam os turnos de trabalho. As estratégias de superação também transcendem os muros e são incorporados dentro do estilo de vida dos agentes.

As características dos integrantes deste grupo apontam, além disso, para um profissional oriundo de estratos já marginalizados de nossa sociedade, composto por uma maioria de não brancos, de origem pobre e que mora em áreas consideradas inseguras. Perfil que, em parte, se parece com a dos internos das prisões.

Por fim, na última década, o agente vem se constituindo numa categoria mais profissional, que começa a se institucionalizar. Esta profissionalização se efetivou de fato com o estatuto que regula a carreira de agente de segurança penitenciário no estado (MINAS GERAIS, 2003) e a criação de um sindicato para categoria (SINDASP-MG). 


\section{Referências}

ALMEIDA, Alberto Carlos; SCHROEDER, Andréia; CHEIBUB, Zairo (Org.). PESB - Pesquisa Social Brasileira, 2002 (Banco de dados). Rio de Janeiro: Universidade Federal Fluminense (UFF). In: Consórcio de Informações Sociais, 2004. Disponível em: < http://www.cis.org.br>. Acesso em: 05 mar. 2010.

BRASIL. Ministério da Justiça. Plano Diretor do Sistema

Penitenciário. Disponível em: http://portal.mj.gov.br/data/Pages/

MJE7CD13B5ITEMID2565B3B35976460E90DA50F35BD61402PTBRIE.htm. Acesso em: 3 ago. 2008

CASTRO, Myriam M. P. Ciranda do medo: controle e dominação no cotidiano da prisão. Revista da USP. São Paulo, v.1, n. 9, p. 57-64, 1991.

CLEMMER, Donald.The Prison Community. New York: Rinehart \& Co, 1940.

COELHO, Edmundo C. A oficina do diabo e outros estudos sobre criminalidade. Rio de Janeiro: Record, 2005.

CORREIA, Ademildo P. Uma análise dos fatores de risco da profissão do 118 agente penitenciário: contribuições para uma política de segurança e saúde na gestão penitenciária. 2006. 66 f. Monografia (Curso de Especialização Latu Sensu - Gestão Penitenciária: problemas e desafios) - Departamento de Ciências Sociais, Universidade Federal do Paraná, 2006.

FERNANDES, Rita de Cássia Pereira et al. Trabalho e cárcere: um estudo com agentes penitenciários da Região Metropolitana de Salvador, Brasil. Cad. Saúde Pública, Rio de Janeiro, v. 18, n. 3, Junho de 2002 . Disponível em <http://www.scielo.br/scielo.php?script $=$ sci arttext\&pid $=$ S0102-311X2002000300029\&lng $=$ en\&nrm =iso $>$. Acesso em: 07 nov. de 2008. Doi: 10.1590/S0102-311X2002000300029.

FOUCAULT, Michel. Vigiar e Punir. Editora Vozes, 1995.

GÓES, Eda; MAKINO, Rosa L. As unidades prisionais do Oeste Paulista: implicações do aprisionamento e do fracasso da tentativa da sociedade de isolar por completo parte de si mesma.Terra Livre, São Paulo, Ano 18, n. 19, p. 163-176 jul./dez. 2002

GOFFMAN, Erving. Manicômios, prisões e conventos. 7. ed. São Paulo: Perspectiva, 2005.

. Estigma: notas sobre a manipulação da identidade deteriorada.

4. ed. Rio de Janeiro: Guanabara Koogan, 1988 
MINAS GERAIS. Secretaria de Estado de Planejamento e Gestão.

Planejamento Plurianual do Orçamento. Disponível em: http:/www. planejamento.mg.gov.br/governo/planejamento/orcamento/arquivos/2008/ Volume5.pdf. Acesso em: 3 ago. 2008.

MINAS GERAIS. LEI 14695, de 30 de julho de 2003. Cria a Superintendência de Coordenação da Guarda penitenciária, a Diretoria de Inteligência e a carreira de agente de segurança penitenciário e dá outras providências. Assembléia Legislativa de Minas Gerais. Disponível em: http:/www.almg.gov.br/consulte/legislacao/completa/completa.html?tipo= LEI $\&$ num $=14695 \& \mathrm{comp}=\& a n o=2003 \& \mathrm{aba}=$ js_textoOriginal \#texto. Acesso em: 3 ago. 2008

KAUFFMAN, Kelsey. Prison Officers and Their World. Cambridge; Haward University Press, 1988.

MORAES, Pedro R. B. Punição, encarceramento e construção de identidade profissional entre agentes penitenciários. São Paulo: IBCCRIM, 2005.

SYKES, Gresham M. The Society of Captives: A Study of a Maximum Security Prison. New York: Princeton University Press, 2007.

KUROWSKI, Maria C.; MORENO-JIMENEZ, Bernardo () Síndrome de Burnout em Funcionários de Instituições Penitenciárias In: PEREIRA, Ana M. B. Burnout. Quando o trabalho ameaça o bem-estar do trabalhador Editora: Casa do Psicólogo, 2002. p. 213 -226.

VASCONCELOS, Ana S. F. A saúde sob custódia: um estudo sobre agentes de segurança penitenciária no Rio de Janeiro. 2000. 65 f. Dissertação (Mestrado) - Escola Nacional de Saúde Pública, Fiocruz, Rio de Janeiro, 2000

WACQUANT, L. As prisões da miséria. Rio de Janeiro: Jorge Zahar, 2001. 


\title{
Saúde mental entre presidiários na cidade do Salvador, Bahia, Brasil ${ }^{1}$
}

\author{
Antônio Carlos Cruz Freire \\ Milena Pereira Pondé \\ Milena Siqueira Santos Mendonça
}

\section{Introdução}

O número de pessoas vivendo em um sistema prisional em todo mundo ultrapassa nove milhões, porém o número de indivíduos acometidos por transtorno psiquiátrico grave nestas instituições é impreciso. (FAZEL; DANESH, 2002) Estudos realizados em diferentes países estimam que os transtornos mentais graves sejam 5 a 10 vezes mais prevalentes entre presos do que na população geral. (BRUGHA et al., 2005; FALISSARD et al., 2006) Transtornos graves de personalidade e transtornos relacionados ao uso de substâncias psicoativas são comuns nesta população. Essas enfermidades têm caráter crônico e não contam com abordagens terapêuticas fáceis. (MORRIS, 2002) Depressão, transtornos ansiosos e transtornos relacionados ao sono são também frequentes, porém, muitas vezes ocorrem associados aos transtornos de personalidade ou uso de substâncias psicoativas. ${ }^{5}$ (WEXLER, 2003)

Os presos têm o mesmo direito de assistência psiquiátrica que o restante da população, contudo poucos pacientes recebem assistência

1 Este trabalho foi realizado com o apoio da FAPESB através do Edital de Segurança Pública (FAPESB/SECTI/SSP). Termo de Outorga ET-06/2005. 
psiquiátrica de maneira adequada durante o período de aprisionamento. Isto representa, em primeira instância, a perda da possibilidade de tratar indivíduos que, habitualmente, não entram em contato com serviços de saúde mental. (SMITH et al., 2003; BIRMINGHAM et al., 1998; LANGEVELD; MELHUS, 2004)

Um estudo australiano examinou se haveria uma maior prevalência de doenças psiquiátricas entre presos quando comparados com a população geral, após realização de ajustes de variáveis demográficas. Utilizando o Composite International Diagnostic Interview (CIDI) como instrumento diagnóstico, estimou-se que a prevalência de transtornos psiquiátricos em prisioneiros foi de $80 \%$, enquanto na comunidade a prevalência foi de 31\%. (BUTLER et al., 2006) Principalmente sintomas de psicose (OR $=11,8,95 \%$ CI 7,5-18,7), transtornos relacionados ao uso de substâncias psicoativas (OR $=11,4$, 95\% CI 9,7-13,6) e transtornos de personalidade (OR = 8,6, 95\% CI 7,2-10,3) (BUTLER et al., 2006).

Uma extensa revisão sistemática da literatura estimou que 3,7\% da população carcerária apresentava um transtorno psicótico, 10\% depressão e $42 \%$ transtorno de personalidade ${ }^{1}$. Na França a prevalência de transtornos mentais em presos do sexo masculino foi estimada através de uma entrevista clínica semi-estruturada (MINI Plus V. 5.0) aplicada por médico e posteriormente entrevista não estruturada com psiquiatra. As seguintes prevalências foram encontradas: depressão 23\%, transtornos ansiosos 13\%, dependência de álcool 8,7\% e drogas 8,.9\%, transtornos psicóticos 13,4\% (FALISSARD et al., 2003). A prevalência de doença mental entre presos não condenados do sexo masculino na Inglaterra e País de Gales foi estimada através de entrevista semi-estruturada, com base nos critérios diagnósticos CID 10: depressão 9,5\%, dependência de álcool e drogas 38\%, transtornos psicóticos 4,8\% e transtorno de personalidade $11,2 \%{ }^{10}$. Um estudo realizado no Irã evidenciou, através da aplicação de escalas semi-estruturadas (SCID CV e PCL SV), aplicadas por médicos residentes em psiquiatria, as seguintes prevalências: depressão 29,1\%; psicose 3,1\%; dependência de opióide ao longo da vida 72,7\%; álcool 8,8\% e psicopatia 25,5\% (ASSADI et al., 2006).

Um estudo australiano examinou se haveria uma maior prevalência de doenças psiquiátricas entre presos quando comparados com a 
população geral, após realização de ajustes de variáveis demográficas. Utilizando o Composite International Diagnostic Interview (CIDI) como instrumento diagnóstico, estimou-se que a prevalência de transtornos psiquiátricos em prisioneiros foi de $80 \%$, enquanto na comunidade a prevalência foi de 31\%. (BUTLER et al., 2006) Principalmente sintomas de psicose (OR $=11,8,95 \%$ CI 7,5-18,7), transtornos relacionados ao uso de substâncias psicoativas (OR $=11,4$, 95\% CI 9,7-13,6) e transtornos de personalidade (OR $=8,6,95 \%$ CI 7,2-10,3). (BUTLER et al., 2006)

Uma extensa revisão sistemática da literatura estimou que 3,7\% da população carcerária apresentava um transtorno psicótico, 10\% depressão e $42 \%$ transtorno de personalidade ${ }^{1}$. Na França a prevalência de transtornos mentais em presos do sexo masculino foi estimada através de uma entrevista clínica semi-estruturada (MINI Plus V. 5.0) aplicada por médico e posteriormente entrevista não estruturada com psiquiatra. As seguintes prevalências foram encontradas: depressão 23\%, transtornos ansiosos 13\%, dependência de álcool 8,7\% e drogas $8,9 \%$, transtornos psicóticos 13,4\%. (FALISSARD et al., 2003) A prevalência de doença mental entre presos não condenados do sexo masculino na Inglaterra e País de Gales foi estimada através de entrevista semi-estruturada, com base nos critérios diagnósticos CID 10: depressão 9,5\%, dependência de álcool e drogas 38\%, transtornos psicóticos 4,8\% e transtorno de personalidade 11,2\%. ${ }^{10}$ Um estudo realizado no Irã evidenciou, através da aplicação de escalas semi-estruturadas (SCID CV e PCL SV), aplicadas por médicos residentes em psiquiatria, as seguintes prevalências: depressão 29,1\%; psicose 3,1\%; dependência de opióide ao longo da vida 72,7\%; álcool 8,8\% e psicopatia 25,5\%. (ASSADI et al., 2006)

Os estudos citados sugerem que a população carcerária necessita de cuidados psiquiátricos para transtornos mentais graves, indicando também que talvez a melhor atenção a esses doentes possa reduzir as taxas de criminalidade. A saúde mental dos presos no Brasil não foi estudada anteriormente. Nós realizamos um estudo de prevalência de transtornos mentais em presos condenados no Estado da Bahia com o objetivo de conhecer o perfil psiquiátrico dos presos deste Estado, através de inquérito semiestruturado baseado nos critérios diagnósticos do DSM IV, adotando um estudo de corte transversal, feito com uma 
amostra de detentos do sexo masculino de duas instituições carcerárias da cidade do Salvador, Bahia, Brasil. A primeira instituição foi um Complexo Penitenciário para cumprimento de pena em regime fechado. A segunda, uma Colônia Penal, em regime semi-aberto. A coleta de dados foi realizada entre os meses de junho e novembro de 2006. O instrumento utilizado foi a tradução para o português do MINI plus (AMORIM, 2000), que fornece o diagnóstico psiquiátrico pelo DSM-IV (manual diagnóstico e estatístico dos transtornos mentais, da Associação Americana de Psiquiatria) e pela Classificação Internacional das Doenças (CID-10), da Organização Mundial de Saúde.

\section{O complexo penitenciário}

Esta instituição abrigava 2343 condenados para cumprimento de pena em regime fechado. O presídio estava dividido em cinco pavilhões, que por seu turno se subdividiam em galerias, que abrigavam as respectivas celas. Os presos a serem entrevistados foram sorteados aleatoriamente através da lista dos detentos fornecida pela direção do presídio. Foram excluídos aqueles que não puderam ser localizados através do sorteio no pátio porque haviam sido transferidos para outro presídio ou outro regime prisional, porque haviam fugido ou porque já haviam sido postos em liberdade. Foram excluídos também os presos que se recusaram a participar da pesquisa, que foram em número inferior a 10.

Foram entrevistados 290 presos, a idade variou de 20 a 63 anos, sendo a média de 33 anos. A depressão ocorreu entre 8 e 17 anos para $12(4,1 \%)$ pessoas, entre 18 e 30 anos para 33 (11,4\%), entre 31 e 54 anos para $6(2 \%)$. A maioria das pessoas teve apenas um episódio depressivo durante a vida 31 (10,7\%), enquanto 20 (6,9\%) indivíduos tiveram entre 2 a 20 episódios depressivos ao longo da vida. O transtorno afetivo bipolar foi o diagnóstico de 19 (6,6\%) detentos, sendo que $4(1,3 \%)$ indivíduos tiveram seus sintomas de humor desencadeados pelo uso de substâncias psicoativas ou medicamentos. O transtorno de ansiedade generalizada foi detectado em 12 (4,1\%) detentos, quadros psicóticos foram detectados em 4 (1,4\%), personalidade antissocial em 78 (26,9\%) e personalidade borderline em 57 (19,7\%) dos internos. O uso abusivo ou dependência de álcool durante a vida foi positivo para 
177 (61\%) presos. No regime fechado as substâncias mais utilizadas e referidas como relacionadas à dependência ao longo da vida foram a maconha 43 (14,8\%), cocaína ou crack 35 (12\%) e os inalantes $3(0,9 \%)$ ou benzodiazepínicos. Com relação à dependência atual de substâncias, 12 (4\%) presos referiam problemas nos últimos 12 meses com maconha. O tipo de substância de abuso atual foi a maconha para 19 $(6,5 \%)$ e estimulante (cocaína ou crack) para 2 (0,6\%). A presença de transtorno de déficit de atenção e hiperatividade (TDAH) na infância foi positiva para 30 internos (10,3\%), enquanto a presença dos sintomas na vida adulta persistiu em 12 presos $(4,1 \%)$.

\section{A colônia penal}

Abrigava 354 condenados cumprindo pena em regime semi-aberto. Neste regime, com autorização judicial, o preso tem o direito de sair em datas festivas, bem como trabalhar fora do presídio e retornar diariamente para a Colônia após a jornada de trabalho. O cumprimento da pena em quaisquer dos regimes é fixado em sentença condenatória, que considera o tempo da pena e o grau de periculosidade do condenado. Todos os condenados terão direito à progressão de regime conforme critério de elegibilidade: do regime fechado para o semiaberto; do semiaberto para o aberto. O condenado que cumprir os requisitos previstos em lei - o cumprimento de fração da pena e bom comportamento prisional - poderá requerer a progressão do seu regime.

Todos os presos que se encontravam no local durante o dia foram entrevistados. Foram excluídos aqueles que não foram encontrados porque estavam trabalhando ou haviam fugido, ou haviam sido transferidos por progressão ou regressão de regime, ou para o hospital de custódia, por apresentarem transtorno mental grave. Foram excluídos também detentos que não concordaram em participar da pesquisa, que foram em número inferior a 10.

Foram entrevistados 207 presos, a idade variou de 19 a 65 anos, sendo a média 29,5 anos, não havendo portanto diferença significativa entre as médias de idade entre os presos dos dois regimes. A depressão ocorreu entre 7 e 17 anos para 12 (5,7\%) pessoas, entre 18 e 30 anos para $20(9,6 \%)$, entre 31 e 65 anos para $7(3,5 \%)$. A maioria das pessoas teve apenas um episódio depressivo durante a vida 21 (10\%), enquanto 
$18(8,7 \%)$ indivíduos tiveram entre 2 a 30 episódios depressivos ao longo da vida.

O transtorno afetivo bipolar foi o diagnóstico de 32 (15,5\%) detentos, sendo que $11(5,3 \%)$ indivíduos tiveram seus sintomas de humor desencadeados pelo uso de substâncias psicoativas ou medicamentos. O transtorno de ansiedade generalizada foi detectado em 15 (7,2\%) detentos, quadros psicóticos foram detectados em 26 (12,6\%), personalidade anti-social em $50(24,2 \%)$ e personalidade borderline em 72 (35\%) dos internos. O uso abusivo ou dependência de álcool durante a vida foi positivo para $140(67,7 \%)$ presos. No regime semiaberto o tipo de substância mais utilizada e causadora de dependência ao longo da vida foi maconha 42 (20\%), cocaína ou crack 24 (11,5\%), seguido de inalantes 1 (0,5\%). Com relação à dependência atual de substâncias, 20 $(9,5 \%)$ presos referiam problemas nos últimos 12 meses com maconha e três internos $(1,5 \%)$ referiam dependência atual a cocaína ou crack. O tipo de substância de abuso atual mais comum foi a maconha para 20 (9,5\%) indivíduos, seguido de estimulante (cocaína ou crack) para

1263 (1,5\%). A Presença de Transtorno de Déficit de Atenção e Hiperatividade (TDAH) na infância foi positiva para 46 internos $(22,2 \%)$, enquanto à presença dos sintomas na vida adulta, persistiram em 11 presos $(5,3 \%)$.

\section{Os presos baianos e os transtornos psiquiátricos}

A prevalência de transtorno psiquiátrico entre prisioneiros no Brasil e na Bahia é pouco conhecida e estudada. Os dados encontrados no presente estudo confirmam resultados de estudos realizados em outros países apontando para prevalências mais altas de transtornos psiquiátricos entre presos do que na população geral. Não houve diferença significativa na prevalência de depressão entre os dois regimes prisionais. A prevalência de depressão ao longo da vida foi de 12,8 a $16,9 \%$, estimativa inferior aos 22,9\% em população carcerária na França. (FALISSARD et al., 2003) Com relação a episódio depressivo atual a prevalência foi de 5,2 a 7.2\%, resultado também inferior à média de 10\% estimada em estudo metanalítico. (FAZEL; DANESH, 2002) 
Com relação a transtornos mentais mais graves, especificamente transtorno bipolar do humor e transtorno psicótico, as prevalências foram significativamente maiores para os presos em regime semiaberto. Esse dado provavelmente reflete o fato da falha da assistência psiquiátrica no regime fechado, levando, provavelmente, à transferência para o hospital de custódia dos presos com transtorno mentais graves nesse regime. Comparando com os dados da literatura mundial a prevalência de psicose do regime semiaberto foi de 12,6\%, semelhante aos 13,4\% encontrados na França (FALISSARD et al., 2006) e 11,5\% nos Estados Unidos (GUY et al., 1985) e maior do que aquela estimada em estudo metanalítico que foi de 3 a 7\%. (FAZEL; DANESH, 2002) A prevalência de psicose no regime fechado foi semelhante à prevalência geral na população, 1,4\%, e menor do que aquela relatada na literatura.

Com relação ao transtorno antissocial de personalidade as prevalências foram semelhantes entre os dois regimes prisionais $(24,2 \%$ a $26,9 \%$ ) sendo menor do que os $47 \%$ referidos em estudo metanalítico. (FAZEL; DANESH, 2002) Com relação ao trantorno borderline de personalidade a prevalência foi significativamente maior entre presos do regime semi-aberto (34,8\%) em relação ao regime fechado (19,7\%), sendo relativamente semelhante aos $25 \%$ reportados em estudo metanalítico. (FAZEL; DANESH, 2002)

A prevalência de transtornos de ansiedade não diferiu significativamente entre os dois regimes prisionais. A prevalência de transtorno de ansiedade generalizada (4,1 a 7,2\%) também foi menor do que os 15,4\% reportados em prisões na França FALISSARD et al., 2006). A dependência e o abuso atual de álcool foram significativamente mais frequentes entre os presos em regime semiaberto. Como o regime semiaberto possibilita um maior contato com o mundo externo, esse pode ser um fator relacionado à maior prevalência do consumo abusivo e dependência atual entre os presos do regime semiaberto. $\mathrm{O}$ abuso durante a vida não difere entre os dois regimes, porém a dependência durante a vida foi significativamente maior para os presos do regime semiaberto, o que nos leva a pensar que talvez existam características comuns entre os presos em regime semiaberto em relação àqueles em regime fechado que os levem a um maior risco de dependência de álcool. No que concerne a problemas relacionados ao uso de outras substâncias a dependência atual de substâncias foi significativamente 
maior entre os presos em regime semiaberto. $\mathrm{O}$ abuso atual e a dependência durante a vida, contudo, não diferiu entre os dois regimes.

Em comparação com outros estudos, o presente estudo indica prevalências mais elevadas de problemas relacionados ao uso de substâncias. Falissar et al. (2006) estimaram uma prevalência de 8,7\% de dependência de álcool, atual ou durante a vida e 8,9\% de dependência de droga, atual ou durante a vida. (FALISSARD et al., 2006) Guy et al. (1985) estimaram em 25\% uso ou dependência de álcool e 11,5\% de drogas. (GUY et al., 1985) No presente estudo, a dependência ou o abuso atual ou durante a vida chegam a 35\% para álcool e 32,4\% para outras substâncias. Como as entrevistas foram realizadas no pátio do presídio e não em área administrativa, pode-se pensar que os internos tenham se sentido mais à vontade para expressar atos que poderiam ser considerados ilícitos. Esses dados indicam um grave problema relacionado ao abuso e dependência de substâncias entre criminosos no Estado da Bahia, Brasil.

A prevalência de TDAH na vida adulta foi semelhante entre os dois regimes prisionais $(4,1 \%$ no regime fechado e 5,3\% no regime semiaberto) e à estimativa de $4,4 \%$ relatada na literatura recente. (KESSLER et al., 2006) As prevalências de TDAH na infância foram significativamente maiores entre os presos em regime semi-aberto, enquanto que a prevalência entre adultos não diferiu entre os dois regimes. Considerando que nem sempre o adulto se lembra com exatidão a época em que teve determinados sintomas, apresentamos os dados considerando que os sintomas apareceram na infância sem considerar a idade de início. No regime fechado a prevalência de 10,3\% se aproxima àquela da literatura para crianças escolares na mesma região, que estimou uma prevalência de 6,7\%. (PONDÉ; FREIRE; 2007; FREIRE; PONDÉ, 2005) No que concerne ao regime semiaberto, contudo, as estimativas de $22,2 \%$ são bastante superiores àquelas encontradas na literatura de referência. Estudos de seguimento mostram que existe uma elevada tendência à criminalidade e atos anti-sociais entre adolescentes e adultos que tiveram TDAH na infância. (MANUZZA et al., 1989; MANUZZA et al., 2008) Pode-se supor que os presos em regime semiaberto tenham cometido crimes menos graves do que aqueles em regime fechado e que assim as crianças com TDAH na infância talvez estejam propensas à criminalidade, porém com crimes menos 
graves na vida adulta. Esses dados devem ser investigados em estudos posteriores que analisem os tipos de crimes cometidos entre aqueles que tiveram TDAH na infância e aqueles que não foram acometidos por essa doença.

\section{Referências}

FAZEL, S; DANESH, J. Serious mental disorder in 23000 prisoners:

a systematic review of 62 surveys. Lancet, v. 359, n. 9306, p. 545-50, 2002.

BRUGHA, T. et al. Psychosis in the community and in prisons: a report from the British National Survey of psychiatric morbidity. Am J Psychiatry, v. 162, n. 4, p. 774-80, 2005.

FALISSARD, B. et al. Prevalence of mental disorders in French prisons for men. BMC Psychiatry, v. 21, p. 6-33, 2006.

MORRIS, M. Managing the unmanageable: psychotherapy in Grendon Prison. Crim Behav Ment Health, v. 12, n. 2, p. 54-67, 2002.

WEXLER, HK. The promise of prison-based treatment for dually diagnosed inmates. J Subst Abuse Treat,v. 25, n. 3, p. 223-231, 2003

SMITH, S. S; BAXTER. V. J; HUMPHREYS, M. S.Psychiatric treatment in prison: a missed opportunity? Med Sci Law, v. 43, n. 2, p. 122-126. 2003.

BIRMINGHAM, L; MASON, D; GRUBIN, D. A follow-up study of mentally disordered men remanded to prison. Crim Behav Ment Health, v. 8, p. 202-213. 1998

LANGEVELD, H; MELHUS, H. Are psychiatric disorders identified and treated by in-prison health services? Tidsskr Nor Laegeforen. v. 124, n. 16, p. 2094-2097, 2004.

BUTLER, T. et al. Mental disorders in Australian prisoners: a comparison with a community sample. Aust N Z J Psychiatry, v. 40, n. 3, p. 72-6, 2006. BROOKE, D. et al;. Point prevalence of mental disorder in unconvicted male prisoners in England and Wales. BMJ. v. 313, n. 7071, p. 1524-7, 1996.

ASSADI, S. M. et al. Psychiatric morbidity among sentenced prisoners: prevalence study in Iran. Br J Psychiatry. v. 188, p. 159-64, 2006.

AMORIM, P. Mini International Neuropsychiatric Interview (MINI): validação de entrevista breve para diagnóstico de transtornos mentais. Rev Bras Psiquiatr.v. 22, n. 3, p. 106-15, 2000. 
GUY, E; PLATT J. J; ZWERLING, I.; BULLOCK, S. Mental health status of prisoners in an urban jail. Crim Justice Behav. v. 12, n. 1, p. 29-53, 1985.

KESSLER, R. C. et al. The prevalence and correlates of adult ADHD in the United States: results from the National Comorbidity Survey Replication. Am J Psychiatry. v. 163 n. 4, p. 716-23, 2006.

PONDÉ, M. P; FREIRE, A. C. Prevalence of attention deficit hyperactivity disorder in schoolchildren in the city of Salvador, Bahia, Brazil.

ArqNeuropsiquiatr, v. 65, p. 240-244, 2007.

FREIRE, A. C; PONDÉ, M. P. A pilot study of prevalence of hyperactivity and attention deficit disorder in scholar children in Salvador, Bahia, Brazil. Arq Neuropsiquiatr, v. 63, n. 2B, p. 474-8, 2005.

MANNUZZA, S. et al. Hyperactive boys almost grown up. IV. Criminality and its relationship to psychiatric status. ArchGen Psychiatry, v. 46, n. 12, p. 1073-9, 1989.

MANNUZZA, S; KLEIN, R. G, MOULTON, J. L. Lifetime criminality among boys with attention deficit hyperactivity disorder: a prospective follow-up study into adulthood using official arrest records. Psychiatry Res, v. 160, n. 3, p. 237-46, 2008. 


\section{A saúde mental de infratores presos numa unidade prisional da cidade do Salvador}

Maria Thereza Ávila Dantas Coelho

\section{Introdução}

Em muitos países, a saúde mental dos presos tem sido alvo de investigação e de investimentos no que diz respeito ao desenvolvimento de ações assistenciais. Segundo Fazel e Danesh (2002), em 2002 existiam cerca de nove milhões de prisioneiros encarcerados em todo o mundo. Esses autores fizeram uma revisão bibliográfica em 62 levantamentos psiquiátricos realizados em doze países ocidentais - Austrália, Canadá, Dinamarca, Finlândia, Irlanda, Holanda, Nova Zelândia, Noruega, Espanha, Suécia, Inglaterra e Estados Unidos -, que incluíam 22790 presos, e encontraram os seguintes resultados entre os homens: 3,7\% apresentavam transtornos psicóticos; 10\%, depressão maior e $65 \%$, transtornos de personalidade, dentre os quais $47 \%$ diziam respeito ao transtorno de personalidade antissocial. Entre as mulheres, $4 \%$ apresentavam transtornos psicóticos; $12 \%$, depressão maior e $42 \%$, transtornos de personalidade, dentre os quais $21 \%$ também se referiam ao transtorno de personalidade antissocial. Em comparação com a população geral, americana e inglesa, os detentos apresentavam taxas duas a quatro vezes maiores de transtornos psicóticos e depressão 
maior e taxa cerca de dez vezes maior de transtorno de personalidade antissocial. Entretanto, embora em todo o mundo milhões de prisioneiros sofram de transtornos mentais, o estudo conclui que não se sabe como as unidades prisionais têm lidado com este problema.

Na Inglaterra, o estudo de Nurse e outros (2003) revelou que a taxa de suicídio entre presos era seis vezes maior do que a taxa da população em geral e que $14 \%$ das prisioneiras e $7 \%$ dos prisioneiros possuíam um transtorno psicótico, quando a média da população geral era de $0,5 \%$. Esse estudo, realizado numa prisão do sul da Inglaterra, revelou ainda que o ambiente prisional incrementa sentimentos de cólera, frustração e ansiedade; que as longas horas de tédio contribuem para o uso nocivo de drogas; que as relações negativas entre funcionários e prisioneiros elevam o nível de estresse de ambos e que o número insuficiente de funcionários afeta o controle e monitoramento da violência e diminui o tempo de contato do preso com seus familiares.

De acordo com Birmingham (2003), problemas de saúde mental são a causa mais significativa de morbidade nas prisões. Mais de $90 \%$ dos prisioneiros têm um transtorno mental. $\mathrm{O}$ ambiente prisional, as regras e o regime de governo das prisões são prejudiciais à saúde mental e os presos têm recebido uma pobre assistência neste aspecto. Embora o Serviço Nacional de Saúde da Inglaterra não fosse antes obrigado a atender este grupo populacional, espera-se que ele se envolva cada vez mais com esta população, já que ela possui o direito de receber uma assistência igual aos demais segmentos, de modo que o cuidado em saúde adquira padrões aceitáveis.

Ainda segundo Birmingham (2004), mais de 8.75 milhões de pessoas estão presas em todo o mundo, com índices maiores nos Estados Unidos (1.96 milhões), China (1.46 milhões) e Rússia (0.92 milhões). Embora na Inglaterra este número caia para 72.500 pessoas, ele cresceu mais do que 50\% na última década. Nesse país, estudos da década de 1990 mostraram que transtornos mentais são particularmente prevalentes entre prisioneiros, com taxas superiores às encontradas na população em geral em relação a distúrbios psicóticos, neuróticos, de personalidade e uso abusivo de drogas. Múltiplos diagnósticos são comumente encontrados entre os reincidentes. Os sintomas neuróticos mais frequentes são: insônia, preocupação, fadiga, depressão e irritabilidade. É comum que presos mentalmente enfermos não recebam 
tratamento por falta de reconhecimento de suas necessidades de tratamento. No ambiente prisional, as alterações de comportamento são mais vistas como problemas disciplinares do que como necessidades de saúde.

Segundo relatório do HM Inspetorate of Prisons (2007), pessoas mentalmente enfermas ainda estão sendo inapropriadamente criminalizadas e os serviços de saúde mental das prisões não atendem satisfatoriamente às necessidades dos presos. $\mathrm{O}$ documento aponta que todos os profissionais dos serviços de saúde mental deveriam receber regularmente supervisão e ter a oportunidade de desenvolvimento profissional. Todos os funcionários da segurança deveriam também receber periodicamente treinamento para conscientização sobre os problemas de saúde mental dos detentos.

Edgar e Rickford (2009), em seu relatório sobre as necessidades de saúde mental dos presos, colocaram uma questão central para toda essa discussão: alguém prescreveria a uma pessoa mentalmente enferma um tipo de ambiente como o prisional? Estima-se que 70\% da população carcerária tenha dois ou mais diagnósticos de transtorno mental, sobretudo transtornos neuróticos, transtornos de personalidade e uso abusivo de drogas. Essa comorbidade é maior do que na população em geral. Cerca de 60 a 70\% dos presos faziam já uso abusivo de drogas antes mesmo do encarceramento e, em 2006, quase a metade da população carcerária da Inglaterra possuía sérios problemas advindos do uso de drogas. Um outro dado relevante é que cerca de 20 a $30 \%$ dos prisioneiros possuem dificuldades ou distúrbios de aprendizagem, sendo a taxa de dislexia em torno de 30\%. Entretanto, menos de 7\% são diagnosticados. No que diz respeito à habilidade de leitura, cerca de $60 \%$ dos presos tem uma habilidade igual ou abaixo a de uma criança de cinco anos de idade. Faltam profissionais especializados para tratamento desses problemas.

Há, portanto, um profundo abismo entre as necessidades individuais dos presos e o despreparo das equipes de trabalhadores do sistema prisional, de modo que a permanência da não assistência a essas pessoas agrava o estado de saúde delas e aumenta o risco da reincidência criminal. (EDGAR; RICKFORD, 2009) Os autores informam que, nos anos de 1996 e 1997, enquanto o número de pessoas encaminhadas pela corte ou pela prisão ao Sistema Nacional de Saúde e aos hospitais 
independentes permaneceu o mesmo, a população carcerária cresceu 41\%. A Justiça Criminal fez pouquíssimo uso (menos de 1\%) da exigência de tratamento em saúde mental na comunidade. Muitos presos são admitidos nas prisões sem nenhum relatório médico e aí faltam especialistas em saúde mental para avaliar, diagnosticar precocemente e tratar os portadores de transtornos mentais. As falhas de comunicação interna e entre as prisões agravam esse problema. Estima-se que, numa prisão com 550 homens sentenciados, seria necessária uma equipe especializada em saúde mental com 11 profissionais de dedicação integral. $\mathrm{O}$ amplo leque de problemas mentais entre os presos requer respostas diversas, multidisciplinares, que incluem psicoterapia, assistência social e terapia medicamentosa, a depender do caso.

Em outros países, esse quadro se repete. O estudo retrospectivo de Rao (1993), feito durante quatro anos na única prisão de Barbados, que abrigava mais de 500 pessoas, revelou que, a qualquer tempo, $20 \%$ desta população sofre de alguma enfermidade mental. Dos 211 pacientes estudados durante o período, 78,2\% apresentavam histórico de transtorno mental anterior ao encarceramento. Na Nova Zelândia, o estudo de Tiaki (2004), por sua vez, apontou que o número de prisioneiros com transtornos mentais cresceu significativamente no período de 1999 a 2004. No período de 2002 a 2004, nos Estados Unidos, 49\% de internos em prisões estatais e $40 \%$ de detentos em prisões federais possuíam algum transtorno mental. (BENDER, 2006; JAMES; GLAZE, 2006) Nas prisões estatais americanas, cerca de $34 \%$ dos presos receberam tratamento no período do encarceramento, tendo sido a prescrição de medicamentos o tipo de tratamento mais comum.

A existência de pesquisas, relatórios e debates sobre a saúde mental dos presos, em todo o mundo, contrasta com a nossa realidade nacional. No Brasil, estudos de avaliação da saúde mental têm sido feitos buscando, sobretudo, investigar a prevalência de transtornos mentais na população em geral (COSTA et al., 2002; BUSNELLO et al., 1993; ALMEIDA FILHO et al., 1992) ou em certos segmentos populacionais que não o prisional, a exemplo dos trabalhos de Paula e outros (2007) com crianças e adolescentes; Santos e outros (2006) com cuidadoras de crianças; Gastaud e outros (2006) com estudantes de Psicologia; Camacho e outros. (2006) com gestantes e recém-paridas; Porto e outros (2006) com professores da rede pública e privada; Araújo e outros 
(2005) com mulheres adolescentes; Reis e outros (2005) com professores da rede municipal; Gallucci Neto e Marchetti (2005) com epilépticos; Facundes e Ludermir (2005) com estudantes da área de saúde; Veggi e outros (2004) e Lopes e outros (2003) com funcionários de uma universidade; Fernandes e outros (2002) com agentes penitenciários; Andrade e outros (1999) com mulheres; Araújo e Silvany Neto (1998) com professores da rede particular e Fernandes e Almeida Filho (1997) com trabalhadores de informática. Chama-nos a atenção a enorme escassez de pesquisas e de artigos científicos sobre o estado de saúde mental de infratores presos. Um dos poucos estudos que investigou essa questão foi o de Oliveira e Teitelbaum (1999), que realizaram uma pesquisa entre mais de mil infratores em cumprimento de pena nas mais de noventa casas que compunham, na época, o sistema penitenciário gaúcho. Os resultados desse estudo revelaram que 22,6\% dos presos apresentavam transtorno de personalidade antissocial; $14,7 \%$, outros transtornos de personalidade; 7,7\%, alcoolismo; 6,6\%, deficiência mental; 2,5\%, drogadição; 2,4\%, distúrbios sexuais; 0,7\%, transtornos psicóticos. O trabalho de Diuana e outros (2008) foi também um dos poucos que abordou a questão da saúde no sistema prisional, porém o fez a partir da tuberculose, da DST/AIDS e das representações e práticas dos agentes penitenciários. Praticamente não existem pesquisas, no Brasil, de avaliação da saúde mental de infratores presos.

Essa lacuna adquire maior gravidade nos tempos atuais, sobretudo quando levamos em consideração o incremento da violência criminal (RAMOS, 2007; ZALUAR, 2007) e os esforços de inclusão da violência na agenda da saúde pública. (MINAYO, 2006) Inúmeras e variadas demandas emergem da sociedade brasileira e clamam por soluções. (MINAYO, 1994) A violência que circula no país, afeta e altera a saúde dos indivíduos, provocando mortes e sequelas de ordem física e psíquica. Cada vez mais o tema da atenção à violência vem sendo debatido no campo da saúde. Tem-se defendido a urgência de se tratar essa questão como um problema de saúde pública, devido aos efeitos que os atos violentos produzem na saúde da população. (BRASIL, 2005)

Dentro desse contexto, buscamos realizar um estudo exploratório de avaliação da saúde mental de presos em uma unidade prisional da cidade de Salvador. A ideia é que tal iniciativa possa colaborar para a realização de outras pesquisas correlatas e para o planejamento de 
ações de saúde mental tanto no sistema prisional, quanto nas comunidades. As novas políticas públicas têm apontado, justamente, para a importância de ações intersetoriais. Nesse sentido, a saúde vem sendo pensada não apenas a partir do setor saúde, mas também a partir de outros setores da sociedade, como, por exemplo, o da segurança pública. (MINAYO, 2006) Da mesma forma, a segurança pública vem sendo debatida intersetorialmente, incluindo o setor saúde, dentre outros. (CANO, 2006)

\section{Metodologia}

Este é um censo exploratório (ALMEIDA FILHO; ROUQUAYROL, 1994), realizado com detentos em uma unidade prisional masculina, de regime semiaberto, na cidade de Salvador, no ano de 2006. Todos os 259 presos que se encontravam nessa unidade prisional, na época, participaram do estudo. Para a coleta de dados foram utilizados dois instrumentos: um questionário sobre os dados sociodemográficos, jurídicos e de saúde dos presos e um outro questionário de avaliação da saúde mental, intitulado Self-Reporting Questionnaire (SRQ-20). Os dados investigados pelo primeiro questionário foram: idade, escolaridade, estado civil, posse de filhos, naturalidade, crime praticado, reincidência criminal, tempo de cumprimento da pena, exercício de atividade laborativa e realização de tratamento psicológico ou psiquiátrico.

No que diz respeito ao SRQ, este é um instrumento que foi recomendado pela Organização Mundial da Saúde (OMS) para uso em populações de países em desenvolvimento. As suas vinte primeiras questões (Parte A) foram validadas para a população brasileira por Mari e Williams (1986). Elas são utilizadas para triagem de morbidade psíquica neurótica, enquanto que as quatro perguntas finais (Parte B) sugerem transtorno mental psicótico. No presente estudo, foi considerado que um escore de sete ou mais pontos na Parte A seria sugestivo de algum transtorno psicológico, o que se mostra condizente com o ponto de corte adotado por diversos outros estudos.

Após consentimento prévio, através de termo por escrito, os 259 presos responderam oralmente às vinte primeiras perguntas do SRQ, assim como às questões referentes aos dados sócio-demográficos, 
jurídicos e de saúde que lhes foram solicitados. As informações coletadas foram inseridas numa planilha criada através do software Excel e posteriormente tratadas de acordo com os objetivos do estudo. A análise dos dados se deu em duas etapas. Na primeira, foi levantado o perfil sociodemográfico, jurídico e de saúde dos presos, assim como o índice sugestivo de transtorno mental, apresentados pelos mesmos. Na segunda, questões foram problematizadas a partir dos resultados colhidos. O estudo foi submetido ao Comitê de Ética e Pesquisa da Universidade Salvador (UNIFACS), tendo recebido aprovação para sua realização.

\section{Resultados}

No que diz respeito aos dados sociodemográficos dos participantes da pesquisa, verificamos que a maioria dos presos possuía idade entre 20 e 29 anos (58,7\%), escolaridade correspondente ao $1^{\circ}$ grau incompleto $(73,7 \%)$, estado civil solteiro $(87,2 \%)$ e tinha filhos $(68 \%)$. Cerca de $40,1 \%$ deles, era natural da cidade de Salvador, enquanto 47,5\% era proveniente do interior do Estado da Bahia.

Em relação ao histórico judicial, por sua vez, identificamos que a maioria dos presos havia cometido o crime de roubo $(66,8 \%)$, não era judicialmente reincidente (70,3\%), possuía um tempo de cumprimento da pena de até cinco anos (77,6\%), não realizava qualquer atividade laborativa (63\%) e nunca havia feito qualquer tratamento psiquiátrico ou psicológico (90\%).

Quanto à presença de transtorno mental nessa parcela da população, verificamos que 32 detentos revelaram dados compatíveis com transtornos psicológicos menores $(12,4 \%)$. Tanto entre os portadores de transtorno mental quanto no total dos participantes, as queixas de tristeza, ansiedade e insônia foram, nesta ordem, as mais frequentes, o que revela que o sintoma depressivo era o predominante, seguido de ansiedade e, posteriormente, do sintoma psicossomático.

\section{Discussão}

Dentre os dados sociodemográficos dos participantes desta pesquisa, a baixa escolaridade é um dos fatores que tem sido associado 
à violência. (MACEDO et al., 2001) Tal fator, ligado a outros aspectos que dizem respeito à ruptura de vínculos da vida social, configura o estado de exclusão social em que vive essa parcela da população em nosso país, o que tem sido considerado como um agente facilitador ao cometimento de atos infracionais. (CARVALHO et al., 2006) Sabemos que o incremento de projetos educativos entre os jovens é uma das estratégias fundamentais de prevenção primária da criminalidade ou da reincidência criminal, que deve, portanto, ser também implementada a nível secundário, com os segmentos vulneráveis ao cometimento de atos violentos, e a nível terciário, com os autores dos crimes, aprisionados. (CANO, 2006) Pela escolaridade dos participantes desta pesquisa, podemos verificar que eles permaneceram na prisão com o baixo nível de escolaridade com o qual entraram nela ( $1^{\circ}$ grau incompleto), o que demonstra a baixa cobertura de projetos educacionais neste ambiente prisional e aponta para a necessidade de avaliação desta população no que diz respeito à existência de transtornos de aprendizagem.

Uma outra importante estratégia de prevenção da criminalidade diz respeito à realização de atividades de formação profissional com os jovens. (CANO, 2006) Em nosso estudo, 63\% dos apenados não realizava qualquer atividade laborativa, ainda que estivesse no regime semiaberto e que, sob tal condição, o trabalho externo lhe fosse permitido. A predominância do crime de roubo entre eles (66,5\%) parece apontar para a desigualdade econômica em nossa sociedade e para a influência, portanto, dos fatores socioeconômicos na criminalidade, como já foi trabalhado por Fandiño Marino (2002). Muitos dos detentos que participaram deste estudo se encontravam desempregados quando cometeram o delito e/ou foram presos. É sabido que as nossas prisões abrigam os excluídos, os pobres, os estrangeiros em sua própria nação (SEQUEIRA, 2006) e que, enquanto tal situação perdurar, dificilmente conseguiremos reduzir os índices de criminalidade e aumentar a segurança pública em nosso país.

A presença de transtornos mentais no ambiente prisional pode estar associada ao aumento da população carcerária, sem a correspondente adequação das condições físicas e de pessoal do cárcere. (DIUANA et al., 2008) Fatores como as precárias condições de higiene, ventilação e acomodação das celas; a superlotação; o sofrimento oriundo da perda da liberdade, da separação de familiares e amigos, da interrupção dos 
projetos de vida e do estigma de criminoso; a falta de uma assistência regular de saúde e a disseminação de doenças neste ambiente revelam as condições insalubres do lugar. A definição de saúde mental de Silva (2004) como o estado de equilíbrio psíquico originado pela relação entre elementos individuais e ambientais, através de um pleno exercício das capacidades mentais e de uma interação saudável com o ambiente, corrobora a idéia segundo a qual um ambiente insalubre é perturbador da saúde mental. A não adaptação às normas legais que disciplinam o cotidiano prisional e aos códigos e regras de convivência da cultura institucional também pode colaborar para o surgimento de um transtorno mental. (SOUZA, 2010)

É importante ressaltar que este estudo foi feito numa unidade prisional de regime semiaberto, na qual os detentos cumprem penas menores ou já se encontram mais próximos de readquirir sua liberdade. Em uma outra unidade, de regime fechado ou diferenciado, é provável que se encontre uma estimativa de transtorno mental ainda mais elevada, assim como uma maior taxa de reincidência criminal. Verificamos em nosso estudo que os indivíduos supostamente portadores de algum tipo de transtorno mental não possuíam assistência psicológica ou psiquiátrica em sua unidade prisional. Faltavam profissionais para isso, uma vez que os pouco existentes cumpriam uma outra função, a pericial, prevista na Lei de Execução Penal. (ARRUDA, 2006) Como vimos, $90 \%$ dos avaliados nunca havia feito qualquer tratamento psiquiátrico ou psicológico ao longo de toda a sua vida. É importante lembrar que, de acordo com a pesquisa de Diuana e outros (2008), a imagem que os agentes de segurança penitenciária mantêm acerca das pessoas presas fundamenta uma desvalorização das queixas que estes últimos manifestam quanto a seu estado de saúde. Os detentos são percebidos, muitas vezes, como incapazes, indolentes e dissimulados, não sendo considerados como interlocutores confiáveis. O sofrimento psíquico, por exemplo, não parece ser percebido como motivo suficiente para suscitar a assistência à saúde ou para evidenciar que algo não vai bem.

Sabemos que o direito universal à saúde está presente tanto no artigo 196 de nossa Constituição (BRASIL, 1988), quanto no artigo 25 da Declaração Universal dos Direitos Humanos (1948). Sabemos também que as ações de promoção da saúde e a assistência à saúde mental podem muito 
colaborar para a prevenção da criminalidade e para a reintegração social do preso. No ambiente prisional, entretanto, a oferta de saúde parece estar inscrita numa relação de dívida e gratidão, dependente do mérito, da disciplina e da adesão aos valores hierarquizantes e às negociações que aí são feitas. (DIUANA et al., 2008) Tanto o problema de saúde quanto o cuidado estão associados à fraqueza e à submissão, sendo incompatíveis com a imagem de força e de poder reivindicada pelos presos e pelos agentes penitenciários. Isso dificulta tanto a demanda quanto a oferta do cuidado. Dentro desse contexto, é necessário transformar valores e fazer valer o direito fundamental à saúde de modo incondicional e universal. Para tanto, é importante questionar os diferentes sistemas simbólicos que dão suporte para a segregação, negação de direitos e restrição da autonomia das pessoas privadas de liberdade e realizar regularmente ações de tratamento e de promoção da saúde, assim como estudos de avaliação da saúde mental da população carcerária, utilizando, inclusive, outros instrumentos de avaliação.

\section{Referências}

ALMEIDA FILHO, N. et al. Estudo multicêntrico de morbidade psiquiátrica em áreas urbanas brasileiras (Brasília, São Paulo, Porto Alegre). Rev. ABPAPAL, v.14, n. 3, p. 93-104, 1992.

ALMEIDA FILHO, N.; ROUQUAYROL, M.Z. Fundamentos metodológicos da epidemiologia. In: ROUQUAYROL, M.Z. Epidemiologia e Saúde, 4. ed. Rio de Janeiro: MEDSI, 1994. p. 157-83.

ANDRADE, L.H.S.G. et al. Epidemiologia dos transtornos mentais em uma área definida de captação da cidade de São Paulo, Brasil. Rev. Psiquiatr. clín., v. 26, n. 5, p. 257-261, 1999.

ARAÚJO, T.M.; SILVANY NETO, A.M. (Org.). Condições de Trabalho e Saúde dos Professores da Rede Particular de Ensino. Salvador: Sindicato dos Professores no Estado da Bahia/Universidade Federal da Bahia/ Confederação Nacional dos Trabalhadores em Estabelecimentos de Ensino; 1998.

ARAÚJO, T.M.; PINHO, O.S.; ALMEIDA, M.M.G. Prevalência de transtornos mentais comuns em mulheres e sua relação com as características sóciodemográficas e o trabalho doméstico. Rev. Bras. Saude Mater. Infant., v. 5, n. 3, p. 337-348, 2005.

ARRUDA, A. Lei de Execução Penal (lei 7.210/84) e Legislação Correlata. 
Rio de Janeiro: Roma Victor; 2006.

BENDER, E. Data Confirm MH Crisis Growing in U.S. Prisons. Psychiatr News, v. 41, n. 20, p. 6, 2006.

BIRMINGHAM, L. The Mental Health of Prisoners. Advances in Psychiatric Treatment, n. 9, p. 191-201, 2003.

BIRMINGHAM, L. Mental disorder and prisons. Psychiatric Bulletin, n. 28, p. 393-397, 2004.

BRASIL. Constituição da República Federativa do Brasil. Brasília: Senado Federal: Centro Gráfico, 1988. 292p.

BRASIL. Ministério da Saúde. Secretaria de Vigilância em Saúde. Impacto da Violência na Saúde dos Brasileiros. Brasília, 2005. 342 p. Disponível em: http://portal.saude.gov.br/portal/arquivos/pdf/impacto_violencia.pdf. Acesso em: 31 maio 2009.

BUSNELLO, E.D. et al. Morbidade psiquiátrica na população urbana de Porto Alegre. J. bras. psiquiatr., v. 42, n. 1, p. 55-60, 1993.

CAMACHO, R.S. et al. Transtornos psiquiátricos na gestação e no puerpério: classificação, diagnóstico e tratamento. Rev. psiquiatr. clín., v. 33, n. 2, p. 92-102, 2006.

CANO, I. Políticas de segurança pública no Brasil: tentativas de modernização e democratização versus a guerra contra o crime. Sur, Rev. int. direitos human., v. 3, n. 5, p. 136-155, 2006.

CARVALHO, M.L. et al. Perfil dos internos no sistema prisional do Rio de Janeiro: especificidades de gênero no processo de exclusão social. Ciênc. saúde coletiva, v. 11, n. 2, p. 461-471, 2006.

COSTA, J.S.D. et al. Prevalência de distúrbios psiquiátricos menores na cidade de Pelotas, RS. Rev. bras. epidemiol., v. 5, n. 2, p. 164-173, 2002.

DECLARAÇÃO UNIVERSAL DOS DIREITOS HUMANOS. Assembléia Geral das Nações Unidas; 1948. Disponível em: http://www.mj.gov.br/sedh/ ct/legis_intern/ddh_b ib_inter_universal.htm. Acesso em: 31 maio 2009.

DIUANA, V. et al. Saúde em prisões: representações e práticas dos agentes de segurança penitenciária no Rio de Janeiro, Brasil. Cad. Saúde Pública, v. 24, n. 8, p. 1887-1896, 2008.

EDGAR, K.; RICKFORD, D. Too Little, too Late: an independent review of unmet mental health need in prison. London: Prison Reform Trust, 2009.

FACUNDES, V.L.D.; LUDERMIR, A.B. Transtornos mentais comuns em estudantes da área de saúde. Rev. Bras. Psiquiatr., v. 27, n. 3, p. 194-200, 2005. 
FANDIÑO-MARINO, J.M. Análise comparativa dos efeitos da base socioeconômica, dos tipos de crime e das condições de prisão na reincidência criminal. Sociologias, n. 8, p. 220-244, 2002.

FAZEL, S.; DANESH, J. Serious mental disorder in 23000 prisoners: a systematic review of 62 surveys. Lancet, n. 359, p. 545-550, 2002.

FERNANDES, R.C.P. et al. Trabalho e cárcere: um estudo com agentes penitenciários da Região Metropolitana de Salvador, Brasil. Cad. Saúde Pública, v. 18, n. 3, p. 807-816, 2002.

FERNANDES, S.R.P.; ALMEIDA FILHO, N. Validação do SRQ-20 em amostra de trabalhadores de informática. Rev. bras. saúde ocup., v. 24, n. 89/90, p. 105-112, 1997.

GALLUCCI NETO, J.; MARCHETTI, R.L. Aspectos epidemiológicos e relevância dos transtornos mentais associados à epilepsia. Rev. Bras. Psiquiatr., v. 27, n. 4, p. 323-328, 2005.

GASTAUD, M.B. et al. Bem-estar espiritual e transtornos psiquiátricos menores em estudantes de psicologia: estudo transversal. Rev. psiquiatr. Rio Gd. Sul, v. 28, n. 1, p. 12-18, 2006.

\section{HM INSPETORATE OF PRISONS. The Mental Health of Prisoners:}

a thematic review of the care and support of prisoners with mental health needs. London: 2007. Disponível em: http://inspectorates.homeoffice.gov. uk/hmiprisons/thematic-reports1. Acesso em: 4 jun. 2009.

JAMES, D.J.; GLAZE, L.E. Mental Health Problems of Prison and Jail Inmates. U.S. Department of Justice. Office of Justice Programs. Bureau of Justice Statistics. Special Report. Sept. 2006. Disponível em: < http://bjs. ojp.usdoj.gov/index.cfm?ty=pbdetail\&iid=789 >. Acesso em: 14 nov. 2009.

LOPES, C.S.; FAERSTEIN, E.; CHOR, D. Eventos produtores de estresse e transtornos mentais comuns: resultados do Pró-Saúde. Cad Saude Pública, n. 19, p.1713-1720, 2003.

MACEDO, A.C. et al. Violência e desigualdade social: mortalidade por homicídios e condições de vida em Salvador, Brasil. Rev. Saúde Pública, v. 35, n. 6, p. 515-522, 2001.

MARI, J.J.; WILLIAMS, P. A validity study of a psychiatric screening questionnaire (SRQ-20) in primary care in the city of São Paulo. Br J Psychiatry, n.148, p. 23-26, 1986.

MINAYO, M.C.S. A violência social sob a perspectiva da saúde pública. Cad. Saúde Pública, v. 10, n. 1, p. 7-18, 1994.

MINAYO, M.C.S. A inclusão da violência na agenda da saúde: trajetória 
histórica. Ciênc. saúde coletiva, v. 11, n. 2, p.375-383, 2006.

NURSE, J.; WOODCOCK, P.; ORMSBY, J. Influence of environmental factors on mental health within prisons: focus group study. BMJ, n. 327, p. 480-3, 2003.

OLIVEIRA, O.P.; TEITELBAUM, P.O. Delinqüência no Rio Grande do

Sul: um estudo da população carcerária. In: Tavares dos Santos JV, editor. Violência em tempo de globalização. 1ed. São Paulo: Hucitec; 1999. p. 503-21.

PAULA, C.S.; DUARTE, C.S.; BORDI, I.A.S. Prevalência de problemas de saúde mental em crianças e adolescentes da região metropolitana de São Paulo: necessidade de tratamento e capacidade de atendimento. Rev. Bras. Psiquiatr., v. 29, n. 1, p.11-17, 2007.

PORTO, L.A. et al. Associação entre distúrbios psíquicos e aspectos psicossociais do trabalho de professores. Rev. Saúde Pública, v. 40, n. 5, p. 818-826, 2006.

RAMOS, P.R. A imagem, o som e a fúria: a representação da violência no documentário brasileiro. Estud. av., v. 21, n. 61, p. 221-239, 2007.

RAO, M.R. The prevalence of mental illness in a prison population - a fouryear retrospective study. West Indian med. J, n. 42 (Suppl. 1), p. 48, 1993.

REIS, E.J.F.B. et al. Trabalho e distúrbios psíquicos em professores da rede municipal de Vitória da Conquista, Bahia, Brasil. Cad. Saúde Pública, v. 21, n. 5, p. 1480-1490, 2005.

SANTOS, D.N. et al. Mental disorders prevalence among female caregivers of children in a cohort study in Salvador, Brazil. Rev. Bras. Psiquiatr., v. 28, n. 2, p. 111-117, 2006.

SEQUEIRA, V.C. Uma vida que não vale nada: prisão e abandono políticosocial. Psicol. cienc. prof., v. 26, n. 4, p. 660-671, 2006.

SILVA, M.L. Racismo e seus efeitos na saúde mental. In: ANAIS DO SEMINÁRIO SAÚDE DA POPULAÇÃO NEGRA, 1., 2004, São Paulo. Anais... São Paulo: Editora, 2004.

SOUZA, C.A.C. Doentes Mentais em Prisões e em Casas de Custódia e Tratamento: um Grande e Permanente Desafio à Psiquiatria e à Lei. Disponível em < http://www.hospitaldepsiquiatria.com.br/menu_03/artigos/ art_007.htm>. Acesso em: 28 mar. 2010.

TIAKI, K. Caring for prisoners' mental health: prison nursing is a specialised area of practice, demanding a wide range of nursing skills and a good dose of life experience. Here one prison nurse outlines some 
of the challenges of caring for the mental health of prisoners. Nursing New Zealand, 2004. Disponível em: < http://findarticles.com/p/articles/ mi_hb4839/is_8_10/ai_n29123476>. Acesso em: 04 jun. 2009.

VEGGI, A.B. et al. Índice de massa corporal, percepção do peso corporal e transtornos mentais comuns entre funcionários de uma universidade no Rio de Janeiro. Rev. Bras. Psiquiatr. v. 26, n. 4, p. 242-247, 2004.

ZALUAR, A. Democratização inacabada: fracasso da segurança pública. Estud. av., v. 21, n. 61, p. 31-49, 2007. 


\section{Pedófilos e agressores sexuais de crianças e adolescentes: narrativas a partir do cárcere}

José Gonçalo Estrela Zúquete

Ceci Vilar Noronha

\section{Introdução}

No tocante aos crimes relacionados à violência sexual contra crianças e adolescentes pouco se sabe sobre os agressores e também, para além da mídia, pouco se fala deles. Quem são estes indivíduos que estão privados de liberdade por práticas sexuais envolvendo crianças e adolescentes? Como eles falam de seus crimes? São estas as questões que causaram inquietação e foram decisivas para a realização desta pesquisa, efetuada em um dos principais cárceres da Bahia.

Em relação aos agressores, o que se pode afirmar com base na literatura especializada é que não existe um perfil único de pedófilo nem de agressores sexuais, sendo estes oriundos de todos os estratos sociais. Sabe-se que os atos de pedofilia são majoritariamente cometidos por adultos que se movem em ambientes frequentados por crianças, seja o meio escolar, familiar, educativo ou recreativo. (ANTUNES, 2003)

Pádua (2009) também conclui que o agressor sexual de crianças é descrito com diferentes perfis e motivações. Por conseguinte, a fim de descortinar a sua perspectiva é necessário desenvolver uma análise 
interdisciplinar, pois o comportamento destes agentes tem uma origem multifatorial e envolve diversas situações de relacionamentos.

Entre os pedófilos, distinguem-se os que usam a violência física como forma de controlar as suas vítimas e os que para as atrair preferem a sedução e a manipulação. (GONÇALVES, 2003) No que tange à estratégia de manipulação, o agressor vai estabelecendo relações de amizade, conquistando a confiança da vítima e desta forma, evoluindo até conseguir alcançar o seu objetivo. De acordo com Freitas (2003), suborno, enganos, ameaças e contatos pseudoeducativos, insinuando informar sobre a sexualidade e a vida, são estratégias frequentemente utilizadas por eles.

Contudo, se por um lado, pedofilia tornou-se um vocábulo vulgarizado pela mídia, sendo este também utilizado pelo senso comum de forma a denominar a maior parte dos crimes sexuais contra crianças e adolescentes, entre os estudiosos ou agentes públicos não há consenso. De fato, a denominação "pedofilia" e "abuso sexual”, por conta das múltiplas interpretações que suscitam, têm gerado muita discussão entre profissionais das agências de enfrentamento destes crimes e na literatura especializada.

Já no diagnóstico de perturbações mentais DSM IV-TR (APA, 2002), utilizado por psícólogos e psiquiatras, a pedofilia se enquadra dentro das Parafilias, as quais compreendem um conjunto diversificado de comportamentos e práticas sexuais que causam transtorno a outros ou ao próprio sujeito. Os critérios para diagnóstico da pedofilia segundo o DSM IV-TR (APA, 2002) são: a) ter fantasias sexualmente excitantes, impulsos sexuais ou comportamentos, recorrentes e intensos, durante um período de pelo menos seis meses, implicando atividade sexual com uma criança ou crianças na pré-puberdade (geralmente com 13 anos ou menos); b) a pessoa atuar por impulsos sexuais ou fantasias que provocam mal-estar, em grau clinicamente significativo, gerando dificuldades interpessoais; c) a pessoa tem pelo menos 16 anos e ser pelo menos 5 anos mais velha do que a criança ou crianças.

Neste sentido, nem todos os pedófilos são abusadores e nem todos os abusadores de crianças podem ser definidos como pedófilos. Estes últimos possuem uma orientação sexual desviante e necessitam de um tratamento clínico diferenciado, envolvendo as formas de lidar com o seu problema ou mudar o seu comportamento sexualmente não aceito 
pelos códigos sociais e culturais. No entanto, para acentuar positivamente os efeitos das estratégias de prevenção devem-se tratar os dois grupos de agressores com terapias diferenciadas. (FEELGOOD, 2008)

Fora do contexto clínico, Finkelhor (1986) afirma que muitos pesquisadores têm atribuído ao termo pedofilia significados diferentes. Alguns consideram pedofilia qualquer contato ou interesse sexual por crianças, enquanto outros utilizam a terminologia do DSM (APA, 2002) relativo a pessoas que têm um interesse sexual por crianças, exclusivo e não exclusivo, por um período de tempo prolongado. O mesmo pesquisador também usa o termo pedofilia de modo a abranger os comportamentos de qualquer indivíduo que tenha tido contato sexual com crianças, inclusive o incesto.

De fato, tem existido muitas dificuldades relativas ao diagnóstico psicopatológico de pedofilia, o que tem levado estudiosos a utilizar o termo de "molestadores sexuais", ignorando a classificação de pedofilia mais utilizada pela psicologia clínica e psiquiatria. (FEELGOOD, 2008)

Segundo Beck (2003), as crenças que temos sobre nós mesmos e sobre o futuro determinam o modo como pensamos, considerando que os atos e os pensamentos do ser humano estão fundamentados na forma de pensar e ver o mundo, sendo esta influenciada pela cultura.

Agregando novos elementos a essa discussão, Stevens (2001) coloca que os pedófilos possuem uma crença distorcida sobre as relações sexuais, e suas motivações se devem a um conjunto de crenças que fazem com que o agressor adulto se sinta normal, quando pratica sexo com uma criança.

De acordo com a observação de campo realizada neste estudo, a maioria dos reclusos não se enquadraria no perfil psicopatológico de pedofilia do DSM e, por sua vez, nenhum dos entrevistados teve acesso a diagnóstico e tratamento psicológico antes ou depois da sua entrada no cárcere. Ademais, o contexto de trabalho consistiu em um ambiente repressor e restritivo das expressões humanas e, em contraposição a isso, a nossa perspectiva foi a de abrir espaço aos sujeitos entrevistados para que eles recontassem a sua história pessoal e a sua versão sobre o delito. 


\section{Método e técnicas}

O início da pesquisa na Penitenciária Lemos de Brito (PLB) realizou-se após uma autorização escrita do Juízo da Vara de Execuções Penais da Comarca de Salvador (Bahia), no mês de setembro de 2009. Até esta data mantivemos inúmeros contatos e idas e vindas para a realização do trabalho de campo.

Na primeira fase do trabalho de campo na PLB, tivemos que organizar as condições da entrevista através da consulta aos processos dos reclusos, o que ocupou aproximadamente dois meses, visto não haver uma classificação dos presos por tipo de crime sexual - estupro e atentado violento ao pudor, conforme a legislação vigente à época contra crianças e adolescentes que são objeto deste estudo.

No total de 1.171 sentenças arquivadas, encontramos 108 réus que compunham o universo dos prováveis entrevistados para este estudo, ou seja, protagonistas de crimes sexuais contra crianças e adolescentes. Posteriormente, entre setembro a dezembro de 2009, entrevistamos oito reclusos, sentenciados por crimes sexuais contra crianças/adolescentes. Os critérios de seleção dos entrevistados foram diversificados para ter uma visão mais alargada do fenômeno, compreendendo casos em que o processo judicial envolvia uma ou várias vítimas, o crime ter ocorrido em área rural ou urbana, diversidade de idade entre os agressores e sendo o delito cometido tanto por familiares, quanto por desconhecidos das vítimas. Dessa forma, os entrevistados são representativos de várias circunstâncias sociais e criminológicas.

Internamente à instituição, obtivemos um apoio crucial para a realização das entrevistas num local adequado com um ambiente propício para as mesmas - uma sala do serviço médico daquela unidade prisional. Tratando-se de um espaço acolhedor e sem a presença dos guardas foram realizadas as entrevistas, sete delas gravadas, sendo estas realizadas durante a manhã, com duração aproximada de 60 minutos.

Para as entrevistas foi elaborado um roteiro, construído com questões centrais baseadas na revisão bibliográfica do tema. Foi explicado aos reclusos o objetivo do estudo, assim como foi assegurado o anonimato e, somente após o consentimento verbal explícito dos sujeitos, as entrevistas foram gravadas. Os participantes foram ainda informados que não teriam quaisquer ônus ou bônus financeiro ou 
penal pela participação no estudo. ${ }^{1}$ (BRASIL, 1996)

\section{Quem são os agressores sentenciados?}

Em 2009, os 108 reclusos da PLB, protagonistas de crimes sexuais contra criança e adolescentes, eram na sua maioria de baixa renda, com escassos recursos econômicos e pouco escolarizados, não tendo desta forma possibilidades de constituir advogado particular para a sua defesa. A média de idade deles correspondia a 34 anos, com uma variação de 19 a 67 anos. Isto não significa dizer que não há agressores adolescentes, mas no referido estabelecimento encontravam-se detidos apenas os sentenciados adultos.

Em contraste, a média de idade das vítimas era de 9 anos, compreendendo crianças com menos de 1 ano e adolescentes com 17 anos, em sua maioria do sexo feminino $(88,7 \%)$, o que é similar aos achados de outros estudos. (FINKELHOR, 1986; SANDERSON, 2008)

Finkelhor (1984) menciona que as idades mais comuns das crianças vítimas de violência sexual estão entre 8 e 12 anos, embora crianças de menos e mais idade estejam também representadas. Investigações no contexto português e brasileiro mostram que, em mais de $80 \%$ dos casos, os agressores são conhecidos da criança e aproximadamente 70\% destes são membros da sua família. (AZEVEDO, 2006; ANCED, 2009)

A maior frequência de violências sexuais cometidas pelos 108 reclusos foram os abusos sexuais e/ou estupros (44, 2\%) e incesto $(33,7 \%)$, sendo que 1,1\% dos criminosos detidos levaram a vítima ao óbito. A prática de crimes de roubo e estupro, simultanemente, também se verificou entre eles, situando-se acima de $10 \%$. O crime proporcionalmente menos frequente foi o de exploração sexual, registrado em $5,3 \%$ das sentenças.

Uma parte dos internos da PLB que constituiu o universo da pesquisa, 52,6\%, habitava em meio rural, enquanto 46,\% viviam em cidades de grande, médio ou pequeno porte, o que demonstra haver uma propagação deste tipo de violência em diferentes contextos. No entanto, há meios rurais com características urbanas e meios urbanos

1 O estudo foi submetido à avaliação do Comitê de Ética em Pesquisa do Instituto de Saúde Coletiva (CEP-ISC), de acordo com a resolução n 196, de 10 de outubro de 1996 do Conselho Nacional de Saúde, tendo sido aprovado com o parecer nº 035-09/CEP-ISC em 2009. 
com características rurais e, em ambos, podem existir situações de isolamento, condição que parece propiciar a execução dos crimes estudados.

Podemos verificar que a maioria dos crimes sexuais de autoria dos 108 reclusos da Penitenciária Lemos Brito foram cometidos na casa da vítima $(49,5 \%)$, o que denota conhecimento e proximidade entre os protagonistas da violência e suas vítimas, enquanto que $(23,7 \%)$ ocorreram na casa do agressor e $21,7 \%$ em outros ambientes, incluindo espaços públicos.

Após caracterizar o conjunto dos agressores sexuais de crianças e adolescentes, passamos em seguida a explorar algumas dimensões das narrativas dos entrevistados, recuperando a sua visão do delito e aspectos da sua própria vitimização, a partir do momento da denúncia contra si.

\section{A negativa do crime: Por tudo na vida, não fui eu!}

É frequente muitos agressores sexuais de crianças negarem os seus atos violentos, pois vivemos em uma sociedade em que este tipo de crime é tipificado como dos mais reprováveis, sobretudo os casos de incesto. Para eles, admitirem o envolvimento sexual com crianças e/ou adolescentes é passarem para a esfera pública uma realidade escondida no mundo privado, onde eles têm controle sobre os demais membros da família através de ameaças.

Por conseguinte, muitos recursos, alguns objetivos e outros imaginários, são utilizados pelos sentenciados para explicar a sua situação no cárcere. É comum eles atribuírem a denúncia de crime sexual contra si a razões de outra ordem. No caso do entrevistado E4, ele narrou que foi denunciado por conta da inveja que despertou em outros indivíduos, porque ele sempre trabalhou, prosperou acumulando imóveis e, além disso, seus filhos estudam. Ele também recorreu à sua condição de pai para se defender da acusação:

O caso de eu ser acusado de qualquer coisa vai do que o senhor produz e tem. Eu não tive uma usura que existe dentro do senhor. O senhor tem essa casa, então, essa casa é, aliás, a sua é de telha. Então, o senhor vai ficar de olho na minha, que é de laje, o 
senhor vai sempre me querer fazer o mal. Então, o problema foi esse, como até hoje eu digo ao senhor, digo o que eu fiz como um homem e que sempre trabalhava. E eu lutei muito porque larguei minha primeira família tenho duas casas com minha primeira família, num lugar muito bom. Tenho mais duas com essa segunda, agora, vivo bem, minha filha, ela estuda bem. Vivo minha vida razoável com muito trabalho, não pego nada de ninguém, não gosto de nada de ninguém. Nunca me envolvi com nada ruim, então, o problema todo em minha vida foi esse...como eu lhe estou dizendo, eu tenho a maior vergonha de estar sendo acusado por isso. Como eu tô lhe dizendo ao senhor, se a polícia lhe prende o senhor vai ter que sustentar aquilo que a polícia tem que fazer, mas eu tenho comigo, porque eu não fiz, eu não fiz e nem quero fazer com nenhuma, porque eu tenho uma filha, gosto muito de minha filha. Não quero que ninguém faça isso, por que eu vou fazer com a filha dos outros? (E4)

Estes mecanismos psicológicos presentes na narrativa do entrevistado correspondem ao que Beck (1995) denomina de "distorções cognitivas”, ou seja, erros sistemáticos na percepção e no processamento de informações que, acompanhadas por uma compulsão aditiva, são racionalizadas no sentido de neutralizar a responsabilidade do agente, cegando a gravidade de seu ato. Tais distorções estão presentes nos pedófilos.

Assim, neste contexto, a negação do crime é uma constante nos discursos e a elucidação do delito é atribuída à tortura policial - circunstância na qual, segundo os entrevistados, eles confessam "ter" cometido o crime. Usando esta argumentação que se faz plausível em muitas situações de investigação, ao elaborar suas narrativas, os sentenciados passam do lugar de agressor para o lugar de vítima da violência institucional, sentindo-se injustiçados, como podemos constatar no trecho abaixo:

Veja bem...Eu fui acusado por uma menina, em que eu tinha namorado ela e posteriormente tendo um caso sexual com ela, e pela qual eu não tive um caso sexual com ela e nem namorei ela, entendeu? Mas os comentários vieram dizer que eu estava namorando ela com as colegas dela, então, veio a ouvidos da mãe dela e dos parentes dela, né? Então, resolveram fazer um exame dela no Instituto Médico Legal, né? Só que nesse exame médico que ela fez lá deu desvirginidade antiga. Então me denunciaram dizendo que fui eu que tinha tirado a virgindade dela, mas não fui eu. Inclusive não me fizeram exame nenhum. Só fui acusado, ouvido e me 
encontro aqui. Mesmo com a defesa informando o que aconteceu, que eu tinha amizade com ela, mas não namorava ela, não é...não me...não tive caso sexual nenhum com ela, certo? Eu eu to aqui aguardado até o dia que Deus quiser me dar a minha vitória. (E2)

O mesmo entrevistado (E2) afirmou que teve de admitir a autoria do crime sexual diante das autoridades para evitar mais sofrimento físico. Nestes termos, passa ele à condição de vulnerável e de objeto do abuso de poder e de uso excessivo da força por parte dos policiais:

Foi o seguinte, nisso aí tinha uma senhora que morava podia se dizer dentro de minha casa e tinha uma menininha que também ficava e tal. Nisso aí, quando foram dar banho nessa criança, quando foi dar banho nessa criança, acharam como que posso dizer? que a popotinha da menina estava inchada... e aí eles começaram o tumulto [...] aí eu não fui, fui para a casa de minha mãe arranjei um advogado e comecei a contar esse caso todo. Fui preso apanhei muito para confessar o crime, não vou dizer ao senhor que eu vou negar. Eu não fiz, mas tive que dizer a polícia porque eu não aguentava quatro homens em cima de mim pau, pau, pau aí [...] Fui levar minha filha para o colégio, eu sou muito apegado à Deus, é aquele negócio, bateu na assim na cabeça, não vou assistir televisão não. Não deu tempo, quando a polícia chegou, acompanhei, hoje eu estou aqui, essa é minha história. Eu tive de falar para a polícia que tinha feito o ato que estava no processo para me defender porque não podia apanhar muito. Apanhei muito, o agente chegou a me julgar, pois ele colocou um pau no meu reto e tal. Aí fico o quê? Medroso, tem que confessar, mas não existia muita criança para morar na minha casa. Minha casa tá até hoje, lá só mora eu, minha mulher e minha filha pode chegar qualquer hora, qualquer pessoa pode ir, não existe isso e eu sempre trabalhei, não tinha tempo para essa coisa. (E2)

Também outro entrevistado mencionou ter admitido o crime sexual sob tortura e que a denúncia se deveu à inveja da vizinhança, pois alguns conhecidos queriam ficar com seus bens:

Eu sou um homem de Deus, sou católico e trabalhador na terra. Só falei isso porque fui torturado pela polícia [mostrou cicatriz na cabeça], e também partiram-me os dentes, foi a vizinhança que fez isso por inveja e para ficar com minhas terras. (E8)

O E5 apresentou uma postura defensiva, qualificando-se como uma pessoa sem estudos e que não entende nada, dado ser analfabeto e da roça: 
É que o senhor desculpe é que eu sou analfabeto e não entendo nada, não entendo nada sabe como é que é? Agora que eu tô no colégio [na prisão] estudando sabe como é que é? Eu não entendo de nada sabe como é que é? Eu agora é que to começando a aprender a assinar sabe como é que é? Morei na roça sabe como é que é o povo da roça, sabe como é que é? (E5)

Em seguida, E5 elabora uma boa imagem de si, considerando que apesar de não ser letrado é uma pessoa honesta, nascida e criada sob a égide dos bons costumes familiares. Ao mesmo tempo, ele contra-argumenta, revelando seu sofrimento, inapetência e resignação, colocando-se no papel de vítima do sistema de justiça penal:

$E$, sabe, é o seguinte, eu sou uma pessoa que eu vou falar para o senhor, eu nunca tive em delegacia nenhuma, sabe como é que é? Sabe? Eu to com 48 anos vou fazer agora em 2010, 48 anos, sabe como é que é? Eu fui sofrido, eu sofri sabe como é que é na roça. Apesar de que eu estou muito sentido porque nunca aconteceu certas coisas comigo, o senhor sabe como é que é, né? Fui criado em casa de família, sabe, sou de confiança, graças a meu bom Deus, e agora acontecer isso comigo eu to mais sentido por causa disso aí, sabe como é que é? Eu quase nem to comendo nem nada, mas eu entrego nas mãos de Deus. (E5)

Fisher (1994) afirma que os agressores pedófilos possuem egocentricidade, uma fraca imagem de si próprio, são defensivos, possuem pensamentos distorcidos, pensamentos e comportamentos obsessivos, são alheios à sociedade e sexualmente preocupados. O sujeito pedófilo, constantemente, compara o seu self ideal com a sua fraca autoimagem, o que resulta em ver-se a si próprio como incapaz e sem recursos para lidar com várias situações. Assim, o pedófilo possui uma tendência a atribuir aos fatores externos a culpa pelas situações em que ele próprio não consegue lidar, ao tempo em que tende a envolver-se, em primeira pessoa, em circunstâncias nas quais é bem sucedido. Isto é, em situações estruturadas, nas quais ele exerce o controle e, dessa forma, não lhe vão causar ansiedade.

Para E5, a única explicação plausível para a ocorrência do seu envolvimento sexual com a filha da vizinha seria a da desinibição provocada pela ingestão de bebidas alcoólicas. Desse modo, o entrevistado afirma não ter controle sobre si, sendo um destes indivíduos com um fraco impulso e sob a atuação de fatores associados com o 
alcoolismo. Isto pode ser percebido no seguinte trecho da sua narrativa: É o seguinte, pelo que ela falou comigo né? Eu fui acusado, né? Eu, é o seguinte, quem sabe é Deus, né? Só que eu, o que aconteceu eu falo com o senhor e Deus tá vendo, né? Eu estava sentado e bebia aí eu senti assim, pás [faz um estalo dando uma palmada] no banco quando eu senti ela no meu colo, sabe como é que é? Aí eu peguei ela e arriei, mas eu não vi mais nada, eu tava bêbado. O senhor sabe como é que é né? Aí é o seguinte, agora só que eu, é o seguinte eu não tava em si, o senhor sabe como é que é né?... Ah é, eu tava meio é, eu tava muito bêbado, tava, se aconteceu eu não vi nada, sabe como é que é? (E5)

É desse modo que E5 coloca a hipótese do ato de violência sexual como consequência do uso de álcool. Esse recurso ao álcool ou a outras drogas ilícitas parece ser um discurso frequente também entre outros agressores sexuais de crianças. De acordo com Finkelhor (1986), esse tipo de argumento possui um elevado nível de aceitação social, tornando-se, portanto, um álibi válido para muitos transgressores.

\section{Guardar segredo sobre o crime na prisão: se vacilar é agredido!}

De acordo com Foucault (1997), as formas de punição dos crimes foram variando de acordo com o contexto e a época, tendo havido um deslocamento, no Ocidente, de uma sociedade, onde o crime era punido com a tortura e morte dos culpados (uma vez que as dores no corpo eram os elementos constitutivos da pena) para uma sociedade em que a perda de liberdade constitui a forma básica de punição. Por conseguinte, nas sociedades modernas, juntou-se ao castigo do corpo o castigo da alma, atuando este sobre as disposições do coração, do intelecto e da vontade, atingindo não só os agressores, mas as agressividades em geral, as violações e, ao mesmo tempo, as perversões, os assassinatos que são, também, impulsos e desejos.

Nas sociedades modernas, os principais tipos de sanção formal são os que fazem parte do sistema de punição representado por tribunais e prisões, sendo considerado como crime qualquer tipo de comportamento que viole a lei. E, de fato, como menciona Foucault (1997), é a certeza da punição que deve desviar os indivíduos do crime, impondo-se-lhes uma pena para corrigir, reeducar ou curar. 
Contudo, nos contextos de alta criminalidade e onde medra o medo e a desconfiança nas instituições do sistema de justiça, ainda existem também atos de violência coletiva que se expressam nos linchamentos, um tipo de justiça popular, como em outros tempos era comum. Segundo Cerqueira e Noronha (2004) num estudo sobre linchamento realizado na Bahia, a sensação de insegurança e violência fútil leva muitas vezes os cidadãos a agir por seus próprios meios, sendo esta justiça mais uma forma de violência para lutar contra a violência. É neste cenário que se insere a violência por parte da população contra agressores sexuais de crianças ou outros delinquentes.

Se, fora dos cárceres, os agressores sexuais de crianças são estigmatizados como sujeitos anormais e irrecuperáveis, também no mundo prisional tal estigma está presente. Neste sentido, os internos da PLB entrevistados mencionaram ser frequentes os atos de violência física entre os penitenciários, devido a animosidades provocadas pelo convívio forçado. No entanto, quase todos eles afirmaram não haver este tipo de agressão interpessoal no pavilhão em que estão.

Os entrevistados enfatizaram também saber de histórias ou passar por esta experiência, quando estiveram detidos em delegacias, logo após a prisão realizada para averiguar os fatos. Também são comuns casos de agressões e ameaças à integridade física dos detentos nas prisões. A este propósito, constatamos ao ler o processo de um recluso que este tinha sido transferido pelas autoridades de outro complexo penitenciário da Bahia para a PLB por motivos de "segurança", em atenção às ameaças de outros presos contra ele.

O E3 narra que não aconteceu consigo, mas sabe de histórias em que os agressores sexuais de crianças durante epsódios de rebelião podem ser as primeiras vítimas, ou seja, de que entre os internos os estupradores e os delatores gozam do mesmo status desprezível:

Eu creio que não, comigo pelo menos nunca teve nada, mas sempre quando há uma discussão entre os presos eles falam sempre: "ah, eu não sei o quê", "eu não sou estuprador", "eu não sou caguete", então é isso, para eles estuprador e caguete na cadeia, para eles é ficar de escanteio, né? A qualquer momento um desses cidadão pode sofrer, numa rebelião por exemplo, dizem, dizem, que eu nunca vi, que eles querer pegar logo o estuprador e o caguete e botar logo como escudo, entendeu, tava perigoso.(E3) 
O E4 enfatizou também a existência de censura moral e reprovação contra os abusadores sexuais no ambiente prisional. Ele sente-se envergonhado da sua sentença, especialmente quando recebe a visita da esposa e da filha, e declarou-se traumatizado com tudo que lhe aconteceu:

Somos muito criticados, muito, Ave Maria, demais! Dia de visita, minha esposa vem, de quinze em quinze, vem com minha filha. Todo o dia que eu não tenho visita, eu me sinto envergonhado de ter uma criança encostada, junto de mim, porque eu também fiquei traumatizado com isso e, hoje eu digo ao senhor a única criança que eu quero ter é minha filha. É a única que eu quero ter junto de mim, é ela. O resto eu não quero saber de nenhuma e nem fazer o bem a nenhuma, se tiver lá morrendo de fome ela vai morrer de fome porque eu não vou passar lá para dar um prato de comida, porque eu sei o que estou passando, por causa às vezes de uma bondade que o senhor faz. (E4)

Ele relatou também que guarda a sua sentença em segredo por temer sofrer alguma punição dos seus companheiros de cárcere. $\mathrm{Na}$ sua narrativa, afirmou que os agressores sexuais de crianças e adolescentes, genericamente denominados de estupradores, sofrem mais nas prisões, sendo conhecidos casos de violência sexual contra eles. $\mathrm{O}$ trecho a seguir é ilustrativo desta colocação que contempla as ameaças constantes e a necessidade de manter seu crime sob sigilo a fim de manter algum nível de sociabilidade nas prisões:

Eu fui para a delegacia, chego na delegacia eu passei um mês, na primeira eu passei uma noite, na segunda eu passei um mês, aí quando soltava os cara para tomar banho de sol, aí os caras começavam aquela guerra, só se ouve: "Hum, hum eu vou matar, vou matar, vou matar, vou matar". O cara vai fazer não sei o quê. Aí o senhor, é um negócio que eu digo ao senhor, o cara que fez [...]. Acho que ele é um louco da vida, ele é um louco porque é uma vida muito, nem sei lhe dizer, o meu processo é escondido, tudo meu é escondido. Eles tudo se dá comigo porque não sabe meu passado, ando ali com eles, eu vivo com eles tudo. Eles tudo gosta de mim. Agora se for esse caso, aí o cara, bom, o negócio é feio, é feio, feio. Conheci um senhor aqui mesmo, ele, eu acho já praticou isso já duas, três vezes. Eu não disse nada a ele, mas no meu pensamento, meu Deus do céu, como acontece uma coisa dessas! O cara vê que a vida é sofrida do jeito que é, é muito sofrimento, é muito o ladrão, o traficante, esses negócios aí, eles não sofrem, mas o tal do estupro, ele sofre muito, muito, muito...Se o senhor vacilar é agredido, aqui 
não, mas tem lugar que o senhor é agredido, é agredido mesmo, o senhor passa até como mulher. (E4)

No entanto, o entrevistado E4 distingue entre o cárcere nas delegacias, caracterizado como um lugar perigoso porque é mais sujeito ao arbítrio policial, e o aprisionamento em penitenciária. (MACAULAY, 2006) Isso se deve ao fato de que as delegacias estão mais próximas aos contextos onde o crime ocorreu e existe, por outro lado, menos supervisão sobre ações dos policiais. Nestas cicunstâncias de vulnerabilidade extrema, o entrevistado se reporta à proteção divina para explicar sua própria sobrevivência:

Se eles souberem na delegacia que o senhor fez isso, o senhor vai passar como mulher. Eu dei a sorte, graças à Deus, eu sou muito pegado à Deus, nunca aconteceu nada comigo, mas tem muitos que sofre como mulher. (E4)

O E6 relatou ter ouvido muitas histórias de violência contra pedófilos, mas fez uma diferenciação interna dos pavilhões da PLB, onde se registra situações de punição física dos agressores sexuais e outros onde essa situação não acontece:

Sofre! No pavilhão que tô não, se fosse no outro pavilhão não tava aqui. Sempre eu já ouvi essa história que lhe dá o nome de pedófilo né, que os presos não gostam, então, já ouvi muitas histórias. Eles falam que batia na pessoa, que a pessoa é discriminado, era isso, era aquilo e eu vim com muito medo pra cá, e aí ainda tenho né [...] nesse pavilhão tem só paz. (E6)

Ao contrário dos outros, o E7 mencionou ter sido ele próprio alvo de discriminação como abusador sexual dentro da PLB, sendo esta uma experiência também comum a terceiros. Ademais, ele foi o único a fazer referência a mortes no interior dos cárceres motivadas pelo ódio aos pedófilos:

Fui discriminado já, várias vezes com meus companheiros, com os meus companheiros, isso acontece com várias pessoas aqui. Tem gente que não fala, mas acontece! Acontece que, às vezes, tem uns que até morre. O cara não gosta, chega o ponto de uma briga. Aí acontece o caso. (E7)

Giddens (2005) considera o crime como uma inconformidade em relação a determinado conjunto de normas aceitas por um número 
significativo de pessoas de uma comunidade ou sociedade. Todas as normas sociais são acompanhadas por sanções que promovem a conformidade e castigam a não conformidade. E, de fato, os comportamentos desviantes relacionados com violência sexual contra crianças e adolescentes no meio prisional são também moralmente condenados.

\section{Considerações finais}

A partir dos anos 1980, com a elevação das estatísticas criminais e a difusão dos sentimentos de insegurança nas sociedades modernas, estamos passando por um momento de reformulação das expectativas em relação às prisões. Estas, no bojo de outras mudanças sociais, estão sendo contestadas ativamente em relação ao seu projeto disciplinador e de recuperação dos indivíduos. Nestas circunstâncias, a prisão passa a representar uma peça chave na montagem do Estado penal, que encarcera pessoas em proporções cada vez maiores para com isso assegurar a proteção da sociedade. (ZOZZO, 2009)

Neste novo patamar repressivo, houve o endurecimento das leis relativas aos delitos sexuais e os mais pobres e os diferentes estão em posição de maior vulnerabilidade face ao arbítrio das polícias e ao cárcere em condições subumanas e/ou inseguras. Na conformação deste novo modo de tratar as classes perigosas, é o modelo norte-americano de encarceramento crescente que tem inspirado muitos outros países como; Brasil, Argentina, Portugal, Espanha, só para mencionar as culturas ibéricas, mas é um fenômeno que não está circunscrito tão somente a estes espaços.

Ao longo das últimas décadas, poucas estratégias de intervenção têm sido efetuadas dentro do meio prisional relativamente aos agressores sexuais de crianças e adolescentes. De acordo com Jesus (2006), as intervenções são fundamentais, pois deixar os agressores entregues aos mecanismos de punição simplesmente é fechar os olhos para a violência, constituindo-se a pior forma de alimentá-la. Desse modo, é crucial através da narrativa conhecer e desenvolver estratégias de correção e reeducação no ambiente do cárcere a fim de prevenir novos crimes. 


\section{Referências}

ANCED. A defesa de crianças e adolescentes vítimas de violências sexuais: reflexões sobre a responsabilização a partir de dez situações acompanhadas por centros de defesa dos direitos da criança e do adolescente no Brasil. São Paulo: ANCED, 2009.

ANTUNES, F. A Investigação criminal do abuso sexual de menores. Sub Judice, v. 26, p. 45-49, 2003.

APA - ASSOCIAÇÃO AMERICANA DE PSIQUIATRIA. DSM-IV-TR: Manual de Diagnóstico e Estatística das Perturbações Mentais. 4. ed. Lisboa: Climepsi, 2002.

AZEVEDO, M. Maus-tratos à criança. Lisboa: Climepsi Editores, 2006.

BECK, A. Terapia cognitiva: abordagem revolucionária In: ABREU, C. N. et al. (Org.). Psicoterapias cognitivas e construtivistas novas fronteiras e práticas clínicas. Porto Alegre: Artmed, 2003.

BECK, J. Cognitive therapy: basics and beyound. New York: Guildford Press, 1995.

BORN, M. Psicologia da delinquência. Lisboa: Climepsi, 2005.

BRASIL, MINISTÉRIO DA SAÚDE. Resolução 196/96 do Conselho Nacional de Saúde/MS Sobre Diretrizes e Normas Regulamentadoras de Pesquisa envolvendo seres humanos. Diário Oficial da União, 10 out. 1996.

CERQUEIRA, R. T.; NORONHA, C. V. Cenas de linchamento: reconstruções dramáticas da violência coletiva. Psicologia em Estudo, v. 9, n. 2, p. 163-172, 2004.

FEELGOOD, S. Child molester or paedophile? Social versus psychopathological classification of sexual offenders against children. Journal of Sexual Aggression, v. 14, n. 1, p. 33-43, 2008.

. A sourcebook on child sexual abuse. Beverly Hills: Sage

Publications, 1986.

FINKELHOR, D. Child sexual abuse. New York: The Free Press, 1984.

FINKELHOR, D. A Sourcebook on child sexual abuse. Beverly Hills: Sage Publications, 1986.

FOUCAULT, M. Vigiar e punir: nascimento da prisão. Rio de Janeiro: Vozes, 1997.

FREITAS, F. Abuso sexual de menores. In: FONSECA, L.; SOARES, C., VAZ, J. M. (Org.). A sexologia: perspectiva multidisciplinar II. Coimbra: Quarteto Editora, 2003. p. 229-242. 
FISHER, D. Adult sex offenders: who are they? Why and how do they do it? In: MORRISON, T. et al. (Org.). Sexual offending against children, assessment and treatment of male abusers. New York: Routledge, 1994. GONÇALVES, R. A. Maltratantes de crianças: punir, tratar ou controlar? Infância Juventude, v. 3, p. 3, IRS, 2003.

GIDDENS, A. Sociologia. Porto Alegre: Artmed, 2005.

JESUS, N. O círculo vicioso da violência sexual: do ofendido ao ofensor. Psicologia: Ciência e Profissão, v. 26, n. 4, p. 672-683, 2006.

MACAULAY, F. Prisões e política carcerária. In: LIMA, R. S.; PAULA, L. (Org.). Segurança pública e violência: o Estado está cumprindo seu papel? São Paulo: Contexto, 2006. p. 15-30.

PÁDUA, S. Perfil psicológico e comportamental de agressores sexuais de crianças. Revista Psicologia Clínica, v. 36, n. 3, p. 105-111, 2009.

RIBEIRO, M. Violência sexual contra crianças e adolescentes: características relativas à vitimização nas relações familiares. Caderno de Saúde Pública, v. 20, n. 2, p. 456-464, 2004.

SALTER, A. Predadores: pedófilos, estupradores e outros agressores sexuais. São Paulo: Mbooks, 2009.

SANDERSON, C. Abuso sexual em crianças, fortalecendo pais e professores para proteger crianças contra abusos sexuais e pedofilia. São Paulo: Mbooks, 2008.

STEVENS, D. J. Inside the mind of sexual offenders: predatory rapists, pedophiles, and criminal profiles. [S.l: s.n.], 2001.

ZOZZO, M. Populismo punitivo, proyecto normalizador y "prisóndepóstito" en Argentina. Sistema Penal \& Violencia, v. 1, n. 1, p. 33-65, 2009. 


\section{A criança e o sistema prisional}

Cláudia Regina Vaz Torres

\section{Introdução}

A construção de uma infância no entorno das prisões enquanto os pais, principalmente as mães, cumprem pena de reclusão revela que as crianças são cumpridoras solidárias deste encarceramento, uma vez que a dinâmica da vida dessas crianças passa a ser organizada em torno do familiar encarcerado. Carência afetiva e material constante, insegurança e invisibilidade social são apenas aspectos particulares dessa vivência.

As crianças possuem as suas percepções sobre o cumprimento da pena de reclusão do pai e/ou mãe e revelam as suas competências de interpretação acerca da sua realidade social, da prisão, do crime, da dinâmica familiar e das suas perspectivas de vida. Acrescenta-se que o itinerário de cada criança no sistema penitenciário durante o cumprimento da pena de reclusão do pai e/ou mãe é individual, privado e singular; entretanto, as condições de invisibilidade, como sujeitos de direitos, marcam esse percurso e repercutem no seu desenvolvimento e construção da infância.

As condições heterogêneas dessas crianças em relação ao mundo acentuam ao mesmo tempo a diferença e a marca identitária de filho de presidiário que delineiam olhares, interrogações, lugares e conceitos e, surpreendemente, também evidenciam o que escapa à objetivação, ao controle das instituições e ao que foi instituído. A análise da cons- 
trução de uma infância no entorno do contexto de reclusão do familiar revela, provoca, inquieta para pensar o que elas dizem sobre os seus modos de ser criança a partir da realidade que vivem.

Analisar as percepções das crianças que vivenciam a experiência de ter o pai e/ou mãe submetidos à custódia do Estado e as repercussões do sistema prisional na construção das suas identidades, evidenciando o papel do Abrigo para ressignificar os efeitos dessa experiência é a proposta deste artigo, tendo como referência a experiência como psicóloga de uma unidade prisional da Secretaria da Justiça, Cidadania e Direitos Humanos há mais de 12 anos.

Este trabalho resultou de uma pesquisa de doutorado do Programa de Pós-graduação em Educação da Universidade Federal da Bahia realizada entre 2007 a 2010, que se sustentou no percurso teórico e metodológico que concebe a complexidade da vida social das crianças através das suas percepções, ações e interpretações sobre a própria realidade, cujos objetivos foram alcançados através de um estudo de caso que se aproximou do estudo de caso do tipo etnográfico. A escolha por esse tipo de abordagem foi decorrente da complexidade da temática, na qual dimensões psicológicas, sociais e éticas constituíam a realidade, a dinâmica e o movimento das relações existentes no grupo de crianças dos contextos de desenvolvimento estudados.

Constatou-se que existem diferentes posições sobre a entrada e permanência de crianças nas unidades prisionais. Enquanto alguns pais se queixavam do pouco tempo de convivência com a família e da impotência que o encarceramento impõe, tornando-os espectadores do rumo que vai tomando a vida dos seus filhos, outros preferiam não receber os filhos nas visitas a fim de preservá-los e outros prometiam rebeliões diante da possibilidade da proibição da entrada de crianças nas unidades.

Evidenciou-se que as crianças que visitam o pai nos finais de semana convivem com essa realidade e passam silenciosas e invisíveis aos olhos do Estado pelos corredores e celas das unidades prisionais. Muitas delas não ficam isentas às consequências nefastas dessa vivência, principalmente aquelas que enfrentam a violação dos seus direitos, pois podem tornar-se objeto de uso, troca e meio de facilitação para entrada de material indevido - drogas, objetos perfuro-cortantes, etc. - nas unidades. As crianças são vulneráveis à condição do familiar 
dentro da penitenciária, pois o delito cometido pelo mesmo constitui marcas identitárias que possibilitam o reconhecimento entre eles no sistema penitenciário e proporcionam o estabelecimento de relações hierárquicas. Estas marcas demarcam lugares e evidenciam mecanismos de intimidação, controle e vigilância. (TORRES, 2010)

Diante dessa realidade em que as crianças entram, permanecem e constroem as suas infâncias, visitando o familiar, pretende-se discutir a construção do conceito de infância através dos estudos da Sociologia da infância (MONTANDON, 2005; SARMENTO, 2002; 2007) e o conceito de identidades será tratado na perspectiva dos estudos de Vigotski (1998; 2002), Ciampa (1986) e Woodward (2000), entre outros.

\section{Construindo os conceitos de infância e identidades}

A infância é analisada a partir dos estudos da Sociologia da infância (SARMENTO, 2002; 2007) que trata da criança como um sujeito de direitos, que abarca em si proteção e participação social nos diferentes e desiguais modos de construção de infâncias. Considera-se assim o lugar que a criança ocupa nas diferentes organizações sociais, pois os diferentes modos de ser e agir da criança são construídos na interação com as pessoas, nos discursos e nas diversas expectativas sobre os modos de subjetivação desse sujeito.

A concepção da criança como um sujeito de direitos é recente, inaugurou-se com a Modernidade, mas efetivamente expressou-se como instrumento legal e normativo em 1990 com o Estatuto da Criança e do Adolescente. (BRASIL, 1990)

Deste modo o conceito de infância, neste estudo, além de contemplar o que está posto no Estatuto da Criança e do Adolescente (ECA) (BRASIL, 1990) considera a infância como um processo social, histórico e cultural que transcende e transforma a realidade a partir das experiências e das construções simbólicas de cada pessoa na interação com o outro, distanciando-se da ideia de infância como um processo puramente linear e natural que se desdobra em etapas sucessivas e evolutivas. A construção da infância tem a sua dialeticidade, que se entrecruza com pessoas, crenças, leis, lembranças, sonhos e desejos. 
Os estudos atuais sobre a infância partem dos estudos da criança a partir delas mesmas, descortinando a realidade social que emerge das interpretações infantis sobre os seus mundos. Essa ideia rompe com a tradição na Sociologia e assume as crianças como atores sociais que agem no contexto social e constituem-se sujeitos através de processos de adaptação, interiorização, apropriação, reprodução e reinvenção de si. Os seus modos de agir, pensar e relacionar-se constituem processos de construção de identidades que participam na estruturação das suas ordens sociais.

Conhecer as crianças impõe, por suposto, conhecer a infância. Isto vale por dizer que os itinerários individuais, privados e singulares de cada criança só fazem completo sentido se perspectivados à luz das condições estruturais que constrangem e condicionam cada existência humana. Essas condições, relativamente a cada categoria geracional, constituem o pano de fundo sobre o qual intervém cada um dos actores, ou, dito de modo mais rigoroso, exprimem o conjunto de constrangimentos estruturais que cada membro da sociedade continuamente sofre, interpreta, reproduz e refaz na sua interacção com os outros. (SARMENTO, 2002, p. 4)

Desse modo, nos processos de subjetivação e na construção das identidades das crianças, concorrem processos múltiplos e permanentes que produzem diversos modos e estilos de existência. Os processos de construção de identidades dão-se incessantemente em diversos lugares e no confronto com as normas que prescrevem os modos como a pessoa deve ser e se comportar em relação a um conjunto de valores.

As identidades estão associadas à participação em uma categoria ou grupo que envolve significados ou estereótipos. Desse modo, ao assumir uma identidade, há uma pressão social para aceitação dos significados ou estereótipos como pertencentes ao sujeito e autodescritivos.

Woodward (2000) ao analisar como as identidades são construídas, sugere que elas são formadas em comunhão com outras identidades. As identidades são, pois, construções que aparecem sob a forma de oposições binárias, mas acentuando os traços da diferença na sua constituição. A identificação é, pois, um processo de articulação, uma suturação, uma sobredeterminação, e não uma subsunção, não há nunca um ajuste completo, uma totalidade. Como todas as práticas de significação, ela está sujeita ao jogo da différance. 
Entende-se que, para explicar os processos de identificação, não há um ponto fixo e permanente, como também não há uma essência última e universal. Considerações teóricas no campo da Psicologia, através dos estudos de Ciampa (1986), contribuem para ampliar a compreensão do processo de construção das identidades, como um fenômeno social, um processo em constante movimento dialético, construído pela atividade e ação do sujeito, através da articulação de igualdades e diferenças que constituem a história pessoal. Ciampa (1986) explica que ela aparece como um processo, sem características de permanência ou independência entre os elementos biológicos, psicológicos e sociais que a constituem.

Para a análise da condição da construção das identidades das crianças, importa conhecer aspectos do Sistema Penitenciário, suas políticas, relações e desdobramentos e os contextos do desenvolvimento das crianças: as visitas e o Abrigo que acolhe os filhos dos internos.

\section{Crianças, famílias e sistema penitenciário}

Os sistemas penitenciários são instrumentos de aplicação da pena. A pena imposta a quem comete um crime tem um caráter retributivo e preventivo, possui como caracteres atingir o autor do crime, ter sua aplicação disciplinada pela lei e ser proporcional ao crime.

De acordo com Foucault (1987), é um conjunto complexo que reúne além de regulamentos coercitivos, programas correcionais para a delinquência.

Com a instituição da Lei de Execução Penal n ${ }^{0}$ 7.210, de 11 de julho de 1984 (BRASIL, 1984) e depois de elaboradas as Regras Mínimas para o Tratamento do Preso no Brasil, atendendo à determinação da Assembleia Geral da ONU, preceituada pela Resolução n ${ }^{\circ} 2.858$, de 20 de dezembro de 1971 e reiterada pela Resolução n ${ }^{\circ} 3.218$ de 6 de novembro de 1974, foram construídas orientações sobre os limites para a punição dos presos. Entretanto, o sistema penitenciário brasileiro ainda pode ser caracterizado pela ausência de condições dignas de vida que se traduz pelo empilhamento de pessoas em celas com capacidade ultrapassada, falta de higiene, ar, luz, alimentação adequada, acesso deficiente à assistência jurídica e médica, ócio forçado e distanciamento 
da família. Assiste-se na maior parte das penitenciárias brasileiras a difusão da tuberculose, vírus HIV e escabiose, naturalização da violência, sob a forma de extorsões, maus-tratos, estupros, assassinatos, exclusão e escorraçamento de homens - apelidados de fariseus no Estado da Bahia - e mulheres desprovidos de algum dinheiro e apoio familiar.

Ao sistema carcerário que objetiva aplicar sanções aos atos desviantes e conter os distúrbios urbanos no Brasil é acrescido, na análise de Wacquant (2001, p. 11), sociólogo francês que estudou o sistema carcerário e judicial, o estado das prisões do país.

[...] que se parecem mais com campos de concentração para pobres ou com empresas públicas de depósito industrial dos dejetos sociais, do que com instituições judiciárias servindo para alguma função penalógica - dissuasão, neutralização ou reinserção. O sistema penitenciário brasileiro acumula com efeito as taras das piores jaulas do Terceiro Mundo, mas levadas a uma escala digna de Primeiro Mundo por sua dimensão e pela indiferença estudada dos políticos e do público [...].

Depreende-se com o autor que o sistema carcerário brasileiro é assentado na dominação. No Brasil, o Estado Penal foi desenvolvido para controlar as desordens suscitadas pela pauperização do proletariado urbano, pela desregulamentação da economia, pela ausência de programas sociais, pela retração de programas sociais, pela dissimulação e indiferença nas relações humanas e pela dessocialização do trabalho assalariado, estabelecendo uma "[...] ditadura sobre os pobres [...]”. (WACQUANT, 2001, p. 10)

Para Wacquant (2001), a prisão na contemporaneidade possui fundamental importância na manutenção de uma política neoliberal, pois representa a ameaça da punição, o controle dos desvios e produz subjetividades punitivas que realimentam a necessidade da prisão para controlar os pobres. Na sua análise, o crime está atrelado a questões econômicas; entretanto existem tipos penais caracterizados por relações sociais, sem qualquer cunho econômico ou em que as questões econômicas ocupam um lugar secundário, como, por exemplo, o crime contra a vida: homicídio, lesão corporal, entre outros.

Nesse sistema carcerário, durante as visitas, a criança vivencia, assim como o seu pai e/ou mãe reclusa, as consequências das barreiras colocadas pela instituição que separam a vida cotidiana da pessoa interna do mundo externo, convive com os diferentes discursos formulados 
sobre a prisão e os discursos que vêm da prisão, enfrenta a convivência com modelos que cometeram crimes e experimentam a subordinação, exclusão social e vivenciam situações em que se vêem como diferentes. Há uma submissão aos elementos constituintes da prisão e uma identificação da(o) reclusa(o) a um lugar, um posicionamento como pessoa, embora, algumas vezes, a pessoa interna tenha consciência de que essa posição está em conflito com outros modos assumidos por ela. A(o) reclusa(o) é convocada(o) a ocupar outras posições como meio de resolução de conflitos e, assim, as contradições são apresentadas, pois o modo de ser deste sujeito difere do modo como ele se posiciona para ser aceito pela massa carcerária e para sobreviver. As identidades são construídas a partir de negociações.

Constatou-se em pesquisa realizada durante o Mestrado (TORRES, 2004) que, na penitenciária, a convivência entre os presos num ambiente de privação e maus-tratos gera agressões e brigas. Além de haver repressão por parte do sistema, que isola e priva da liberdade como medida punitiva, há também repressão por parte dos outros reclusos que atuam de acordo com um código de conduta interno, elaborado por eles e perpetuado ano após ano. A depender do crime cometido, estupro ou infanticídio, o sujeito fica estigmatizado, pode ser rebaixado e ter que prestar serviços, tais como: lavar, limpar, ceder a sua comarca (espaço de deitar) e dormir junto ao vaso sanitário, oferecer-se sexualmente, etc. aos demais internos, sofrer desprezos e agressões. Os que escapam das humilhações são aqueles que contam como o auxilio principalmente financeiro, da família. O que "perdem do psicológico”, conforme dito por um recluso na ocasião das entrevistas, é que, em função dos conflitos travados entre eles, para ter uma convivência sem tantos atritos, passam a assumir identidades de acordo com os apelos feitos pelos lideres da população carcerária.

Na prisão, o delito cometido constitui marcas identitárias que possibilitam o reconhecimento entre eles no sistema penitenciário e proporcionam o estabelecimento de relações hierárquicas. Estas marcas estão nas paredes das celas, nas grafitagens nos muros, nos corpos tatuados, mutilados e adornados, nas roupas que demarcam os territórios e evidenciam mecanismos de intimidação, controle e vigilância. Estas marcas denunciam ainda os maus tratos, histórias e passagens pelo cárcere. 
Compreende-se que uma prisão é constituída pelas relações que são estabelecidas, o modo como são travadas e negociadas a permanência no lugar, os sentidos da prisão pela sociedade e todos os processos de exclusão vivenciados. Como analisa Foucault (1979), além das decisões, regulamentos que são elementos constituintes da prisão, existem as estratégias, astúcias que não são de ninguém, mas que são, no entanto, vividas, assegurando o funcionamento e a permanência da instituição.

Neste espaço, as crianças passeiam e constroem as suas infâncias, visitando o familiar recluso por diferentes períodos de tempo.

Quanto às visitas, a Lei de Execução Penal de 11 de junho de 1984 (BRASIL, 1984) estabelece que o interno tem direito a visitas semanais. O Conselho Nacional de Política Criminal e Penitenciária (CNPCP, 2007) no Novo Plano Nacional de Política Penitenciária pretende aperfeiçoar o controle das visitas, particularmente as íntimas, em lugares apropriados, como também os procedimentos para a revista da pessoa reclusa, visitantes, servidores ou prestadores de serviços.

A visita, com todas as limitações de tempo e espaço, promove a integração, o contato, o acolhimento, o sentimento de pertencimento a uma outra realidade além do muro. A visita induz a participação dos familiares no cumprimento da pena de reclusão e em algumas situações na responsabilização e no fracasso.

Entende-se que com a mulher há uma dependência emocional em relação ao homem e os valores de uma vida marginalizada não permitem o afastamento. Mães e mulheres, além de visitar o homem recluso, trabalham para ele e por ele, prostituem-se, se necessário for, com outros presos, a fim de garantir a vida ou vantagens, reivindicam melhores condições prisionais, expõem-se a todo tipo de prática delituosa para ajudá-lo. (TORRES, 2004) Em contrapartida, a maioria das mulheres reclusas é abandonada pelo companheiro e recebe pouco ou nenhum apoio da família. Quando recebe visitas é do companheiro que, também, está preso ou do namorado que conseguiu arrumar depois do aprisionamento, através das outras mulheres reclusas que possuem companheiros presos nas outras unidades.

Para visitar o pai e/ou mãe reclusa a criança é submetida à fila na entrada e ao procedimento da revista corporal. A revista ou busca corporal nos familiares dos internos é um dos procedimentos de segurança 
nos estabelecimentos penais que tem um caráter preventivo, uma vez que objetiva impedir o ingresso de celulares, armas ou drogas no ambiente carcerário. Para a realização da revista direta sobre o corpo do indivíduo, o Conselho Nacional de Política Penitenciária (CNPCP) no Art. $2^{\circ}$ exigiu a existência da fundada suspeita de que o indivíduo é portador de objeto ou substâncias proibidas; assim, apenas quando há suspeita é autorizada a revista direta, manual e superficial no corpo e na roupa do revistado. Na verdade, o que ocorre cotidianamente nas visitas é a imposição da revista direta, não havendo qualquer observância do artigo supracitado. Acrescenta-se que não foram estabelecidos os limites da revista manual pelo CNPCP, possibilitando que em algumas ocasiões o agente efetue uma intervenção no corpo da pessoa revistada, tocando-a nas partes íntimas e, com isso, cometendo excessos e arbitrariedades.

Os familiares encontram saídas para os impasses e constrangimentos suscitados pela visita ao familiar, como também desenvolvem habilidades para resolver problemas pontuais, como: conflitos do interno com o ambiente do cárcere, angústias pelo tempo da prisão, falta de dinheiro, queixas em relação a um membro da família e ainda acolher e criar a esperança que pode ajudar o(a) recluso(a) a encontrar novos lugares no sistema onde ele está inserido e no retorno à vida social. A família, então, assegura a relação da pessoa reclusa com o social, auxiliando na preservação do seu bem-estar.

Entre os homens reclusos, a mesma posição de poder e privilégio ocupada pelos líderes é conferida aos seus familiares dentro e fora do sistema penitenciário. Assim, nas visitas, as celas são desocupadas para receber a companheira, filhos, etc., e os demais ocupam a área externa (o pátio) com a construção de tianas que permitem o encontro íntimo. A pessoa reclusa que goza de uma posição hierárquica tira proveito de sua situação e estabelece uma relação de dominação para com os demais reclusos, chegando inclusive a proibir a entrada de uma visita se esta desagrada às lideranças.

Além do momento das visitas às unidades prisionais, a entrada e permanência no Abrigo durante o cumprimento da pena de reclusão do familiar será destacada. 


\section{Centro educativo nova semente: um lar simbólico para filhas(os) das(os) internas(os)}

O Centro Educativo Nova Semente (Abrigo/Creche), dirigido pela Fundação Dom Avelar Brandão, vinculada à Arquidiocese de Salvador e à Pastoral Carcerária funciona há onze anos abrigando bebês e crianças em regime de internato numa área desmembrada do Complexo Penitenciário da Mata Escura. O Abrigo é mantido por convênios federais, estaduais e municipais e doações. Outras crianças, filhos de internos(as) têm atendimento diário e são assistidas com reforço escolar e atividades de estímulo à cidadania. As crianças mais velhas estão matriculadas nas escolas públicas e particulares do bairro e as crianças pequenas frequentam a Creche Nova Semente.

O cotidiano do Abrigo seguindo princípios morais e assistenciais tem como papel acompanhar e direcionar a entrada da criança, a adaptação e permanência, a construção de modos de ser e viver, a manutenção dos vínculos familiares e o retorno ao lar. Identificou-se que acolher e formar hábitos de conduta consiste em disciplinar, assumir atitudes firmes para controlar gestos e impulsos, orientar pelo exemplo, oferecer adequadas condições de vida e submeter afetos e corpos à regulamentação moral. (FOUCAULT, 1987)

As crianças convivem durante as visitas ${ }^{1}$ com o ambiente carcerário que institui uma relação poder-saber para manter o controle e moldar corpos, linguagem e comportamentos (FOUCAULT, 1988), mas para muitas dessas crianças o que prevalece não é o contexto prisional e, sim, o contato afetivo com a mãe. As meninas e meninos idealizam a mãe e identificam-se com as mesmas, principalmente porque é com elas que mantêm um vínculo afetivo. Acreditam que as suas mães não cometeram crimes ou, quando admitem que houve um delito, minimizam a ocorrência e protegem a mesma, tomando-a como vítima. As crianças expressam o quanto as mães estão continuadamente envolvidas na tarefa de assumir os seus cuidados.

O Abrigo é um importante contexto de acolhimento e educação dessas crianças. Os discursos, principalmente religiosos e morais sobre

1 Acrescenta-se que as crianças do Abrigo Centro e Nova Semente não passam pela revista íntima. 
a prisão, o crime, a punição, entre outros, cruzam-se com processos de exclusão, situações estigmatizadoras e tragédias familiares que criam sentidos e efeitos nas construções subjetivas de meninas e meninos. É um processo que sempre é atualizado à medida que entra uma nova criança na instituição. As profissionais do Abrigo apontam saídas distantes dos muros do sistema penitenciário e ampliam as expectativas de uma vida diferente da mãe e/ou pai recluso, a ser começada.

\section{Identidades: crianças e filhos de presidiários}

A construção da identidade das crianças no contexto de ter um pai e/ou mãe presa é conflitante, primeiro porque precisa ver e sentir a situação de aprisionamento e punição do familiar, segundo por conviver num contexto de institucionalização, quando são abrigadas durante o cumprimento da pena de reclusão e terceiro pela condição de pertencer a um grupo: filhos de presidiários.

O crime e a punição são, então, aspectos importantes nos processos de subjetivação e identificação dessas crianças, mas que não definem a trajetória de vida desses meninos e meninas. Assim, o crime, a situação de aprisionamento e punição do familiar, afastamento familiar, abrigamento e ser filho de presidiário são fatores difíceis para uma criança analisar, sustentar, interpretar e conviver, porém não determinam a entrada na vida criminal, semelhante ao ocorrido com o seu pai e/ou mãe reclusa.

Uma educadora no seu depoimento reforça que, "Foi uma realidade triste ver as crianças no cárcere. Foi um choque. Tem que vir a educação para trabalhar isso. Não penso que porque tem um pai lá dentro elas serão aquilo também. Isso não”. (E1, m).

Constatou-se neste estudo que a criança diz quem é através do que conta sobre o fazer do seu pai e/ou mãe, aspecto importante na análise da construção das identidades. Para Ciampa (1986), a criança antes de nascer já é representada como filho de alguém e essa representação prévia o constitui efetivamente e objetivamente como filho e membro de uma determinada família. Posteriormente, essa representação é interiorizada pelo indivíduo e reafirma-se à medida que as relações nas quais estiver envolvido confirmarem essa representação, através de comportamentos e discursos que reforcem a sua 
identificação com o fazer do pai e/ou mãe e com tudo que envolve a dinâmica familiar.

A identificação de uma criança como filho de um presidiário(a) é pressuposta; no percurso relacional, os comportamentos vão ocorrer como consequência das relações e, também, como condição. A criança se vê, identifica-se como filho de presidiário ou filho de um ladrão, etc., é identificado com tal e interpreta, ao seu modo, este dado da sua realidade. Como analisa Ciampa (1986), a posição de um sujeito o identifica, discriminando-o como dotado de certos atributos, de predicações, que dão uma identidade considerada formalmente como atemporal. A construção dessa identidade deixa de ser vista como uma sucessão temporal, passando a ser vista como manifestação de um ser sempre idêntico a si mesmo na sua permanência e estabilidade. Então para estas crianças, essa posição produz uma submissão a essa identidade, a esse lugar, promove uma estabilidade.

Então, recorre-se ao autor para destacar que, na questão da identidade das crianças, evidencia-se a diferença e a igualdade. Por fazerem parte de uma família específica, são identificados como se possuíssem as mesmas características. A compreensão sobre a construção da identidade envolve os significados implícitos e o que é aparente diante de uma ação realizada. Assim, o crime é a atividade realizada que se coisifica pela predicação. O tipo de crime marca o sujeito, tem poder sobre o indivíduo, mantém e reproduz sua identidade, mesmo que seja algo ocorrido no passado. Quem comete um crime recebe uma identificação pelo tipo de crime que cometeu e, ao ser punido, recebe uma outra identificação que passará a portar. É desse lugar e duplo estigma que pai e/ou mãe carregam que uma criança se constrói. As pessoas vão se constituindo umas às outras, ao mesmo tempo em que constituem um universo de significações que as constituem. As identidades envolvem a articulação de várias personagens, articulação de igualdades e diferenças atravessada por uma história pessoal.

Através de conflitos, crises e rupturas do sujeito com o meio, as identidades são interpretadas, negociadas e construídas.

Os depoimentos de técnicas do Abrigo sobre as crianças confirmam:

"A criança tem uma idealização com o pai, tem uma identificação com ele a ponto de realizar atividades [...] ela diz que vai ser médica e 
outras vezes, diz que vai ser chefe como o pai que é chefe dos presos”. $(\mathrm{T} 3, \mathrm{~m})$

"Uma criança disse numa entrevista para um documentário que era um menor infrator. Ele associou que se a mãe estava presa então ele era um menor infrator. Depois as crianças ficaram repetindo e ele disse que não sabia o que era menor infrator [...]”. (T2, m)

Depreende-se que os significantes: prisão, crime e infrator são formados por representações e práticas sociais discursivas que demarcam e atribuem sentidos às identidades dessas crianças. Esta vivência produz marcas simbólicas que possibilitam a construção de um lugar, no qual cada um pode identificar-se e construir a sua história. O último depoimento traz o termo "menor infrator". Menor infrator foi uma identidade que a criança atribuiu a si mesma e que está de acordo com a posição da sua mãe na sociedade por ter cometido um ato delituoso. A percepção de que a má conduta da mãe e a marca identitária associada ao crime e à prisão pertencem também ao filho demonstra a concepção de que o envolvimento com a criminalidade é transmitido de mãe e/ou pai para filho, tornando as crianças alvo de preconceitos e estigmas. Este estigma, conforme depoimento, de algum modo irá mediar as relações estabelecidas por esta criança com o mundo, pois as marcas do preconceito e exclusão estarão presentes no seu processo de subjetivação.

A identidade, então, como explica Ciampa (1986), é representada por um nome, sobrenome e também abre as condições para que outras representações sejam ditas, porque serve como respostas, como a atividade que realiza. Assim, diante da pergunta da pesquisadora à criança sobre quem ela é, há implicitamente a idéia de que existem respostas que a identifiquem como pessoa. É através da atividade de mãe infratora que o menino evidencia a sua identidade, diz quem ele é.

Constatou-se, também, que a criança sofre mais com a prisão da mãe. Nas entrevistas e observações realizadas durante a pesquisa de campo, as educadoras relataram que as crianças não se importam em falar que o pai está preso e o tipo de delito, mas que quanto à mãe custodiada, explicam sempre que a mesma viajou e sentem-se ofendidas quando a genitora é alvo de comentários ou brincadeiras de outras crianças. Segundo depoimentos, as mães são percebidas pelas crianças de modo diferente do pai. A relação da criança com o pai que comete 
um crime, principalmente homicídio e não se desvinculou da família, é de respeito. Quanto à mãe, como não é esperada na nossa cultura a participação e iniciativa da mulher na criminalidade, as crianças sentem vergonha em falar sobre o assunto, ou até mesmo visitá-las.

A visão idealizada que eles têm da mãe sofre um impacto em razão da constatação de que ela se posiciona completamente diferente do que é proposto socialmente para mulheres e homens como fazendo parte da "natureza" feminina; então, vê-la reclusa por conta de um crime que cometeu provoca, entre outros sentimentos, como culpa: dor, vergonha e distanciamento. Então, para essas crianças, falar da mãe presa ou da mãe que cometeu um crime é falar de si mesmas, pois se o modelo não é aceito socialmente, o delas também não será. A naturalidade com que tratam do pai transgressor representa o papel de gênero que mulheres e homens construíram. A mãe é a pessoa mais importante para a criança, é o vínculo mais forte, enquanto o pai como membro da família tem um papel secundário. As ações que o pai realiza não repercutem do mesmo modo na construção identitária da criança como aquilo que a mãe faz.

As crianças internalizaram a partir das suas relações com a cultura que ser mãe é maternar, cuidar da casa, dos filhos e, em algumas situações, do marido. Marcada fundamentalmente para assumir como atribuição a tarefa de orientar filhos e filhas, a manter um lar harmonioso, livre de distúrbios e ser responsável pela educação moral dos jovens (LOURO, 1999, 2003), a mãe, numa situação de aprisionamento, rompe com esses valores construídos socialmente.

Diante dessa condição, meninas e meninos conflitam com os parâmetros a serem seguidos na construção das suas identidades, pois possuem o exemplo de sua mãe transgressora e relacionam-se com pessoas no mundo social que evidenciam o papel de mãe como exemplo de perfeição moral, educação, docilidade e vida sacrificada para dar conta das suas tarefas no âmbito público e privado, sem negligenciar nenhum deles. Resta, então, para as crianças, o silêncio sobre o destino das suas mães em razão do crime cometido e a passagem pelo cárcere.

Todavia o silêncio da criança não minimiza os processos que ocorrem internamente, que envolvem a articulação da igualdade (equivalências) e diferenças que vão implicar em posições no mundo. No cotidiano, manifestam-se os desdobramentos das múltiplas deter- 
minações a que se está sujeito. Como analisa Ciampa (1986), uma rede intricada de representações permeia todas as relações, na qual cada identidade reflete outra identidade. Há um jogo de reflexões múltiplas que estrutura essas relações da criança com a mãe transgressora, com o crime, o sistema prisional e a sociedade e que é mantida pelas atividades dos indivíduos envolvidos.

A criança conflita com essa identidade da mãe transgressora, uma vez que essa identidade surge também como uma representação dela no mundo na relação com o outro. Distanciar-se desse lugar de transgressor é um movimento singular de cada criança ao perceber que o outro pode identificá-lo como idêntico a sua mãe - dotado das mesmas predicações - e vir a sofrer as consequências desse processo; como também envolve ocultar partes e aspectos relacionados à própria história - com a qual pode se identificar e ser identificada - para poder ser aceito.

Outras crianças podem não conflitar com a identidade de mãe transgressora e permanecerem coladas a esse lugar, identificando-se, sendo identificadas, desempenhando papéis decorrentes dessa posição e repondo sempre no presente a marca da transgressão.

Desse modo, como seres sociais, meninos e meninas têm um horizonte de possibilidades de construção das suas identidades, desdobram-se reflexões e ações que transformam o cotidiano dessas crianças e constroem as subjetividades e identidades que se traduzem em desejos, projetos, tendências, entre outros.

As crianças que convivem com o contexto do cárcere agem no contexto social, são competentes para perceber a sua realidade e buscar um ponto de apoio para enfrentar a lógica do silêncio e submissão que ordena o sistema prisional.

\section{Referências}

BRASIL. Lei $n^{\circ} 7.210$, de 11 de julho de 1984. Institui a Lei de Execução Penal. Diário Oficial [da] República Federativa do Brasil, Brasília, DF, 12 jul. 1984. Disponível em: <http://www.planalto.gov.br/ccivil_03/Leis/ L7210.htm>. Acesso em: 01 jun. 2009.

BRASIL. Lei $n^{\circ}$ 8.069, de 13 de julho de 1990. Dispõe sobre o Estatuto da Criança e do Adolescente e dá outras providências. Diário Oficial [da]

República Federativa do Brasil, Brasília, DF, 14 jul. 1990. Disponível em: 
$<$ http://www.planalto.gov.br/ccivil_03/leis/L8069.htm>. Acesso em: 01 maio 2009.

CNPCP - CONSELHO NACIONAL DE POLÍTICA CRIMINAL E PENITENCIÁRIA. Novo plano nacional de política penitenciária. Brasília, 2007. Disponível em: <http://www.carceraria.org.br/fotos/fotos/admin/ Sistema\%20Penal/ Sistema\%20Penitenciario/NOVO_PLANO_NACIONAL_ POLITICA_PENITENCIARIA_2007.pdf $>$. Acesso em: 01 maio 2009.

CIAMPA, Antonio. A estória do Severino e a história da Severina. São Paulo: Brasiliense, 1986.

FOUCAULT, Michel. Microfísica do poder. Rio de Janeiro: Grall, 1979.

. História da sexualidade. Rio de Janeiro: Graal, 1988.

. Vigiar e punir: nascimento da prisão. Petrópolis: Vozes, 1987.

LOURO, Guacira Lopes. Currículo, gênero e sexualidade. In:

NECKEL, Jane Felipe; GOELLNER, Silvana Vilodre. Corpo, gênero e sexualidade: um debate contemporâneo na educação. Petrópolis: Vozes, 2003. p. 41-52.

. Pedagogias da sexualidade In: . $O$ corpo educado: pedagogias da sexualidade. Belo Horizonte: Autêntica, 1999. p. 7-34.

MONTADON, Cleopatre. As praticas educativas parentais e a experiência das crianças. Educação \& Sociedade, Campinas, v. 26, n. 91, p. 485-507, maio/ago. 2005. Disponível em: <http://www.scielo.br/pdf/es/v26n91/ a10v2691.pdf>. Acesso em: 01 jun. 2009.

SARMENTO, Manuel Jacinto Infância, exclusão social e educação como utopia realizável. Educação \& Sociedade, v. 23, n. 78, 2002. Disponível em: <http://www.scielo.br/scielo.php?script=sci arttext\&pid $=$ S010173302002000200015\&lng=\&nrm=iso\&tlng=>. Acesso em: 01 maio 2008.

. Visibilidade social e estudo da infância. In: VASCONCELOS, Vera Maria Ramos; SARMENTO, Manuel Jacinto. Infância (in)visível. Araraquara, SP: Junqueira \& Marin, 2007. p. 25-49.

TORRES, Cláudia Regina Vaz. Desconstruindo a identidade de "criminoso/a": o significado das ações educativas no sistema penitenciário. Dissertação (Mestrado em Educação) - Faculdade de Educação, Universidade Federal da Bahia, Salvador, 2004.

. Por um céu inteiro: crianças, educação e sistema prisional. 2010. 228 p.Tese (Doutorado em Educação)- Faculdade de Educação, Universidade Federal da Bahia, Salvador, 2010.

VIGOTSKI, Lev Semionovich. A formação social da mente: o 
desenvolvimento dos processos psicológicos superiores. São Paulo: Martins Fontes, 1998.

. A formação social da mente. São Paulo: Martins Fontes, 2002.

WACQUANT, Loic. As prisões da miséria. Rio de Janeiro: Zahar, 2001.

WOODWARD, Kathryn. Identidade e diferença: uma introdução teórica e conceitual. In: SILVA, Tomaz Tadeu (Org.). Identidade e diferença.

Petrópolis, RJ: Vozes, 2000. p. 7-72. 


\section{Sujeitos da fronteira. A saída da prisão}

Milton Júlio de Carvalho Filho

\section{Introdução}

Sair da prisão. O que significa? Após um tempo de apartamento forçado da sociedade, homens voltam ao convívio social. Mais complexo do que possa parecer a princípio, não é apenas a abertura dos portões das prisões que define a liberdade.

Este artigo procura discutir o processo de saída da prisão. A pesquisa que dá origem a esse artigo foi desenvolvida entre os anos de 2003 e 2006, no Programa de Estudos Pós-Graduados em Ciências Sociais, Antropologia, na Pontifícia Universidade Católica de São Paulo e depois foi replicada em Salvador, Bahia, entre os anos de 2008 e 2010. Nas duas cidades foram acompanhados, ao longo de três anos, homens que saíram da prisão. A convivência diária com eles, acompanhando-os desde o aviso da soltura, em alguns casos, garante uma aproximação qualificada com esses sujeitos em termos de intensidade, de vivência do seu cotidiano após a prisão, como exige um bom trabalho etnográfico. Em São Paulo, foram acompanhados 15 homens e em Salvador, 12 homens. Entre esses, a idade média estava na faixa entre 25 e 56 anos e foram sentenciados por tipologias penais como roubo, furto, latrocínio, tráfico, homicídio, crimes sexuais e passionais. Expressivamente saíram em liberdade condicional, contra uma minoria em liberdade definitiva.

Partimos do pressuposto de que todo recomeço tem elementos de recordação do passado, da memória, neste caso específico das memórias 
do cárcere. Assim, os sujeitos que saem, oficialmente, das prisões brasileiras movimentam-se, também, com base nas suas lembranças e nos aprendizados oriundos do cárcere. As suas memórias, portanto, são fundamentais para afirmar ou negar as possibilidades de emancipação identitária da condição de ex-preso. A memória do cárcere pode esclarecer sobre a aquisição de padrões éticos e morais da cultura carcerária e como essa possível aquisição ajusta-se às expectativas de renovação da vida, fora da prisão, o que denominamos aqui de emancipação. Assim, visando discutir emancipação, o problema norteador desse artigo pode ser resumido na questão: quando o ex-preso deixará de ser ex-preso?

A implicação do cárcere na vida cotidiana dos sujeitos que saem das prisões pode ser compreendida nas ressignificações que os sujeitos fazem da sua história de vida. É a partir de tais ressignificações que é possível compreender como o homem liberto da prisão física pode potencializar ou despotencializar mudanças. A ressignificação da experiência prisional permite o fortalecimento do nexo entre memória e identidade social. Trabalhar a memória individual com tal finalidade, significa trabalhar em dois rumos, separados e complementares: o primeiro rumo é o metodológico e o segundo o interpretativo.

\section{As saidinhas}

A saída de homens presos em penitenciárias brasileiras dá-se por dois meios: a liberdade definitiva, depois do cumprimento integral da pena ou por meio de liberdade condicional, ficando uma parte da pena a ser cumprida fora da prisão, com algumas restrições. A grande maioria dos presos no Brasil sai em liberdade condicional, depois de cumprirem parte da pena a que foram condenados. Antes da liberdade, seja condicional ou definitiva, muitos presos progridem do regime fechado do cumprimento da pena para o regime semi-aberto aonde podem eventualmente sair para a rua em datas festivas e/ou em feriados, assim como trabalhar fora da prisão, retornando para a mesma a noite.

As saídas, com voltas programadas, geralmente de três a cinco dias, são denominadas pelos presos de "saidinhas". Ocorrem por volta de oito saidinhas por ano, geralmente nos dia das mães, no Natal, no carnaval, no dia das crianças, na Semana Santa e no dia dos pais, entre outras. Tanto em São Paulo, como em Salvador, em torno de 10\% dos 
presos não retornam das saidinhas, tornando-se fugitivos. As saidinhas também não têm nenhum tipo de orientação ou de acompanhamento em termos de programas ou de políticas específicas para esse fim. Os que ficam na prisão por falta de possibilidades de sair ou não acessar esse direito, em muitos casos, estranham os que retornam a ela após o término da saidinha. A "saidinha" serve como uma forma de adaptação ao "mundão", e dessa forma, não exclui o retorno ao mundo do crime. É um estágio para a obtenção da liberdade definitiva ou condicional e assim assume a função de uma adaptação gradativa ao mundo fora da prisão.

Ainda que as saidinhas tenham tal finalidade, em muitos casos o preso cumpre toda a sua pena no regime fechado, pela falta de vagas no regime semi-aberto, ou porque o seu processo corre a sua revelia, sem acompanhamento de advogados privados e sem a devida atenção dos defensores públicos para a progressão do regime fechado para o semi-aberto. "Pagar a pena de ponta" é a forma como os presos denominam os casos em que a pena foi cumprida integralmente no regime fechado, sem ganhos de benefícios. Para Ricardo, preso por oito anos, a cadeia venceu um dia após ter ganhado o benefício da sua liberdade condicional. Ele acompanhava a contagem da sua pena e já sabia que tinha quitado o que devia. Ricardo não cometera nenhum crime hediondo, por isso teria direito a benefícios que, com a existência de advogados de defesa, o teriam tirado da prisão com o pagamento de um terço da sua pena.

A desatenção com a liberdade do apenado se inicia pela precariedade quanto ao acompanhamento dos processos judiciais. Por saber que não podem contar com a agilidade e com a eficiência do Estado na sua defesa, muitos presos, mesmo sem dinheiro, contratam advogados particulares, pagando-lhes de diversas formas: seja com a verba conseguida através do crime que o levou a prisão, seja por meio da venda ou doações aos advogados de bens da família como os móveis de suas casas ou as suas próprias casas e ainda através de acordos de pagamentos futuros, em até 30 dias após a soltura. Essa última modalidade de acordo, geralmente, faz com que eles tenham que reincidir para saldar uma dívida que consideram moral, como lembra Edvaldo: "Tem cara que sai hoje e amanhã volta. Se endividou pra sair e ninguém deixa de pagar quem te tirou de lá. Desde o semi-aberto o cara já entra no ritmo”. 
A saída da prisão traz elementos promotores da solidificação da condição de preso, desde o endividamento de alguns dos presos com os seus advogados, o que pode gerar reincidência; a revolta por ter cumprido uma pena que poderia ser reduzida por meio de benefícios legais se houvesse assistência jurídica e principalmente a falta de ritualização capaz de promover a ruptura com o ambiente prisional. Ainda ressalta-se a exigência de alguns juízes de que o preso apresente, quando solto em liberdade condicional, em até 30 dias, uma carta de emprego como condição fundamental para a manutenção da sua liberdade. Por todos esses motivos estar na rua não significa necessariamente estar livre da prisão.

A liberdade condicional estabelece normas e regras a serem cumpridas como não frequentar bares, não passar das 23h na rua, não portar armas ou entorpecentes, não viajar sem prévio aviso às autoridades e assinar mensalmente a carteira da condicional na Vara de Execuções Criminais. Alguns não têm recursos nem mesmo para ir assinar a carteira, tornando a sua situação judicialmente irregular com a falta de assinatura por três meses. A promoção de uma irregularidade, já pode potencializar na vida do sujeito outras mais graves e desestabiliza o sujeito que na saída quase sempre tem o propósito de reorganizar a sua vida, contrariando o indicado pelas altas taxas de reincidência. As restrições impostas pela modalidade de liberdade condicional não são problematizadas pelos ex-presos. O importante é estar livre: "Lá dentro a gente grita muito por liberdade. Condicional é super normal. Eu fico em casa, no máximo que fico na rua e até as dez horas e entro pra casa. É o mesmo que tá livre de uma vez" (Edvaldo).

\section{Os laudos psicossociais}

A liberdade definitiva, bem como a condicional, são obtidas depois que os presos passam por avaliações psicossociais, realizadas pelos psicólogos e pelos assistentes sociais das prisões. Embora tenham necessidade de escuta profissional e, queiram ser escutados, a grande maioria dos ex-presos se nega a falar a profissionais de Psicologia pelo fato de desconfiarem da atuação do psicólogo da instituição prisional e generalizarem a conduta que consideram pouco adequada profissionalmente. Tal desconfiança nasce da forma como as avaliações 
psicológicas são, geralmente, operacionalizadas: entrevistas curtas e embasadas em roteiro já conhecido pelos presos, que juntos especulam quanto à forma de responder as questões para que possam garantir um laudo final positivo para a sua liberação da prisão, ainda que nem todos os laudos sejam elaborados dessa forma. "Exame psiquiátrico, psicologia, assistente social, psiquiatra...vem esse pessoal e diz que sabe de você denda cadeia...você tá lá no fundo preso, eles te chama na frente, nem tá vendo seu ambiente lá dentro... e como é que ele faz um laudo seu?" (PEDRO).

Os laudos analisados quando favoreciam a libertação do avaliado consideravam a assimilação pelo preso da terapêutica penal; a preservação dos seus vínculos afetivos, além de sua aparência física. De modo geral, os laudos são formais e não traz nenhuma avaliação sobre os danos causados pelo aprisionamento ao sujeito, como se os mesmos não existissem com a assimilação da terapêutica penal. Um dos laudos analisados referia-se a um homem preso por 18 anos, sendo essa a sua segunda avaliação, tendo sido negativa a primeira. Os avaliadores consideram que, apesar de tantos anos de prisão, o avaliado manteve sua memória íntegra e que não apresenta sinais do aprisionamento.

E quais seriam os sinais do aprisionamento nos sujeitos que os laudos não apontam? As transformações comportamentais consequentes do aspecto fundante da prisão: a sujeição dos homens ao poder disciplinar. Foucault (1989), ao analisar variados aspectos da complexidade da organização prisional desde a sua função até as técnicas que estruturam os procedimentos do poder, indica que a disciplina organiza o espaço, classifica os indivíduos, hierarquiza-os, controla o tempo, eficientiza os processos, controla o corpo, coordena os movimentos, atribui vigilância em caráter perpétuo e extensivo, exercendo também um poder e produzindo um saber. A prisão assume, então, duas funções: a função disciplinar e a punitiva. Para Foucault (1989, p. 209), "o encarceramento penal, desde o início do século XIX, descobriu, ao mesmo, tempo a privação da liberdade e a transformação técnica dos indivíduos."

Foucault analisa que no sistema punitivo prisional o isolamento em relação ao mundo exterior à prisão dá-se em função do modelo entender como necessário afastar o sujeito dos fatores que motivariam a infração, mantendo, dessa forma, a higiene pessoal e moral 
dos sujeitos. O afastamento do "mundão" favoreceria, desse modo, a conformidade com as normas prisionais e, como consequência, a passividade, dificultando a rebeldia, condicionando a docilidade e a submissão total. No entender de Foucault (1989, p. 213) "pretendia-se a requalificação do penitente através da relação do indivíduo com aquilo que pode iluminá-lo de dentro". O comportamento do sujeito é moldado durante o aprisionamento e aparece no sujeito que sai da prisão como uma consequência da sujeição imposta pelo modelo disciplinar. Esses aspectos, os laudos não constatam e não inferem. Por outro lado, o poder exercido pelos sujeitos presos como um contra-poder ao imposto, também repercute nos seus comportamentos e ações. Os laudos de saída são extremamente pragmáticos e não auxiliam nem a instituição e nem os sujeitos no sentido de avaliar as reais possibilidades de reinserção promovidas pelo modelo prisional. Ao contrário, a forma como os laudos de saída são elaborados favorecem a própria improdutividade do sistema.

Os laudos não dão conta da complexidade da saída, diante da despotencialização dos sujeitos após a experiência de prisão. O desentendimento sobre esses homens, e deles próprios, quanto a complexidade da sua condição humana, torna difícil qualquer síntese. Essa complexidade que a instituição total esconde, pode ser percebida no momento de saída, principalmente pela ocorrência entre eles de um sentimento comum de despotencialização. Tal despotencialização para a vida fora da prisão, embora tão desejada, em casos extremos faz com que alguns presos ao saírem se mantenham ao redor do estabelecimento prisional por algum tempo, alguns repetem o crime e voltam, muitos reestruturam suas vidas ali na mesma cidade do interior ou bairro onde a prisão se localiza. Nesses casos, a potência de ação, no sentido de retomar a sua existência é quase nula.

Até mesmo na reincidência a prisão se estabelece fortemente, ela é parte integrante do mundo do crime, desde quando o sujeito é mais valorizado por ter vivido a experiência prisional e saído "na vertical”, de pé, numa alusão a ter sobrevivido. Ainda que existam esses casos extremos, a maioria dos que saem demonstram ter alguma potência de ação que o faz tentar restabelecer suas vidas, muito embora indiquem sinais de despotencialização, perceptíveis nas falas sobre o "medo" e a "insegurança" quanto ao retorno ao mundo fora da prisão. 
O medo e a insegurança estruturam-se no sujeito preso e, conseqüentemente, no ex-preso, a partir do que Foucault (1989) considera ser a eficácia da estratégia do isolamento nesse modelo disciplinar prisional. O isolamento tem como caráter básico prevenir a formação da multidão, fazendo com que os presos se curvem ao poder que se exerce sobre eles, despotencializando-os a partir do medo e da insegurança que esse poder gera. Acresce-se a estratégia de isolamento analisada por Foucault a promoção do tormento, da ação silenciosa do remorso e da dor que junto a panóptica arquitetura do espaço, aniquila a personalidade, conduzindo o preso para uma vida nova de um cidadão dócil-útil. Para Foucault, esse ser novo seria o ser da individualidade e da sociabilidade burguesa. Por isso, Foucault (1990) justifica o fato de a prisão figurar como a forma mais imediata e mais civilizada de todas as penas: promover, ao mesmo tempo, a privação da liberdade e a transformação técnica dos indivíduos a partir de suas duas funções e fundamentos - a função disciplinar e a punitiva e o fundamento jurídico por um lado, e o técnico por outro.

A não constatação dos efeitos do aprisionamento pelos laudos vai de encontro à constatação desses efeitos pelos presos quando saem da prisão. O Ser submetido institucionalmente, o Ser que contraria tal submissão através de um contra-poder de um código de ética grupal da massa carcerária e o Ser social pronto a restabelecer relações no mundo externo à prisão se encontram nesse momento da transitoriedade, que é a saída, e implicam na caracterização de sujeitos que vivem esse momento, na limiaridade entre estar preso e estar solto.

Essa vivência na fronteira gera a necessidade de alterar o estado de consciência logo ao sair da prisão. A maioria dos que saem, bebem e não demonstram nas narrativas que a bebida nesse momento integre um ritual comemorativo, pelo contrário, demonstram que a alteração do estado de consciência pela bebida é conseqüência do desentendimento do sujeito na situação de fronteira ou de limiaridade em que vive naquele momento. O caráter abrupto da saída e a falta de ritualização desse momento tão esperado confundem os sujeitos, colocando-os na fronteira entre a prisão e o mundo externo a ela.

Romper a fronteira e manter-se na ordem social inaugura a necessidade de essa ordem dar-se também na esfera da ordem mental. Desse modo, como cita Turner (1974), devem ser elaborados rituais de 
inversão de papéis e, portanto, de valores celebrados como em uma comemoração, em uma festa, como os rituais de rebelião que chegam a ser festejados com rituais de violência. O sair da prisão está presente nas narrativas como um momento em que se equilibram dois lados de uma balança: de um lado, o polo individual acrescido da opressão do sistema prisional; do outro, o polo social pressionado pela libertação ocorrida sem aviso ou preparo prévio. Esses são lados ou polos que equilibram a identidade dos sujeitos. A desorientação, o desentendimento e a desordem surgem no sujeito, nesse momento de saída, como consequência da despotencialização gerada pelo modelo prisional.

\section{O aviso sobre a saída da prisão}

Viver a sujeição do aprisionamento, fortemente marcado pelo poder disciplinar, faz com que os indivíduos sujeitados, estabeleçam uma ética capaz de colocá-los contra o que lhe foi imposto, inserindo-os em um jogo de poder, mesmo que seja para si mesmo. Um dos aspectos dessa ética durante a prisão é ressaltar o passado como uma forma de anular a vivência na prisão. Faz parte dos relatos desse passado a sua relação familiar, a sua relação no seu meio social composto por vizinhos e amigos, além dos hábitos e costumes próprios de cada um.

A saída do espaço prisional representa mais do que o sonho físico de liberdade, principalmente, pelo caráter simbólico do aprisionamento. A partir das narrativas, percebi que o momento de saída da prisão inaugura um estágio da vida desses sujeitos, caracterizado pela limiaridade, onde não se é mais preso, penitente, apenado, mas também não se é ainda completamente livre dessa condição para se viver outra. Da separação ou do rompimento com o aprisionamento até o estabelecimento de uma nova condição impõe-se aos sujeitos ex-presos uma posição marginal: eles não são o que eram, nem o que virão a ser.

O primeiro momento, considerando a saída propriamente dita, é o momento do viver na fronteira. Entretanto, esse estágio pode se estender para alguns e passar a ser uma forma de vida, o que dependerá dos vínculos e das relações sociais estabelecidos. A retomada dos vínculos e das relações de fora da prisão de forma concreta e não idealizada, como fora durante o aprisionamento, estabelecem o primeiro contato com o desconhecido na saída: ter ou não o apoio da família, ter ou 
não maiores ou menores possibilidades de se reintegrar ao seu meio, desconhecer o grau de negatividade na avaliação dos outros quanto a sua condição de ex-preso são algumas das incógnitas desse momento de transitoriedade entre a prisão e o "mundão", a sociedade fora da prisão como denominam os presos.

O entendimento dos sujeitos quanto aos vínculos mantidos a partir da saída, permite que se constitua um painel quanto aos elementos gerais do estágio de transitoriedade vivido por eles, entre a prisão e o "mundão". O primeiro elemento diz respeito à própria forma como se dá o desvínculo físico com a prisão, isto é, sobre a forma como são avisados da saída: um aviso de maneira abrupta, sem preparo prévio, envolvido em gozações e tentativas de desestabilizá-los, um elemento surpresa para os presos. Depois de anos de aprisionamento esses homens são "cuspidos" para fora da prisão, em um ritual que mais os fragiliza do que os auxilia nesse estágio de transitoriedade.

A prisão se estabelece no sujeito inclusive na forma como se dá a saída. "Vê se não volta mais" é a frase síntese de relação de vingança, de descarte e de desresponsabilização dos agentes da instituição para com os seus tutelados. A forma como se dá essa ruptura é extremamente importante do ponto de vista simbólico e pode-se até considerá-la como um dos fatores preponderantes na extensa manutenção, em alguns sujeitos, do estágio de fronteira entre a prisão e o mundão. Ritualizar a saída de forma a auxiliar o sujeito a superar a condição de aprisionamento é fundamental, não apenas do ponto de vista comemorativo de uma nova fase, mas principalmente por gerar o enlutamento da fase anterior. A instituição prisional não ritualiza adequadamente o processo de liberdade tendo em vista romper com a condição de preso e agregá-lo à vida de cidadão comum. A falta de ritualização adequada da saída da prisão cria a impossibilidade dos sujeitos simbolizarem a sua saída, o que é necessário à organização psíquica do sujeito que sai. Falar sobre a saída e ritualizá-la possibilitam a sua reordenação simbólica.

Como se dá esse processo de ruptura com a prisão e a retomada de uma condição também rompida com o aprisionamento? O primeiro passo para compreender a complexidade desse processo de tantas rupturas é entender como se dá, o que podemos considerar como um ritual de saída. A saída é avisada ao preso, em muitos casos, horas antes 
de acontecer, em outros com, no máximo, um dia de antecedência. Como conta Irineu, toda saída é envolvida em ralhas e brincadeiras por parte dos agentes penitenciários e por tentativas de desestabilização, ao invés de avisarem sobre a saída, avisam que o preso regredirá do regime semi-aberto, novamente para o regime fechado:

Faz parte do ritual de saída as doações dos bens agregados durante o aprisionamento. Os outros presos, geralmente os mais próximos, denominados "irmãos de cela”, ao saberem da saída de um companheiro solicitam a sua herança material da prisão: TVs, rádios e até objetos pessoais como canecos e pratos são doados aos que ficam. Poucos levam para casa os objetos que conseguiram juntar na prisão ao longo de anos e alguns vendem para os outros como forma de angariar algum dinheiro para a saída. Doar os bens estabelece uma forma de solidariedade entre os presos, uma maneira de comunicar uma irmandade através da herança. Por outro lado, essa mesma irmandade oferece um risco. Ao saber da notícia da sua liberação, o preso quer sair imediatamente do pátio com receio de vinganças por parte de outros presos, por conta de inveja ou rixas entre grupos. Geralmente informam da saída só para os mais próximos.

De modo geral, a saída dá-se sem mesmo a família ser avisada. A desinformação é a tônica desse processo e pode ser justificada por alguns motivos: a morosidade da justiça associada à falta de advogados para a maioria dos presos que não podem custear a sua própria defesa. Os presos perdem-se no acompanhamento dos trâmites dos seus processos. Alguns inferem a proximidade da saída através de uma contagem informal dos benefícios que eles mesmos pleitearam através de um colega preso, mais experiente em questões de direito ou através do setor da judiciária das prisões, encarregado de organizar as petições e solicitar benefícios. Também os estabelecimentos penais não dão atenção ao processo de saída por desconsiderá-lo como uma atividade irrelevante e não pertinente ao seu objetivo social: guardar homens tutelados judicialmente pelo Estado.

Essa desconsideração com o processo de saída depõe a favor da improdutividade do sistema prisional como um sistema de reabilitação social. O aviso de saída vem como uma surpresa ou através de procedimentos confusos e até de punições. Os estabelecimentos penais, em raríssimos casos, têm um serviço de orientação e comunicação da saída ao preso. 


\section{Quando os portões se abrem}

Os sujeitos sentem-se como exilados que retornam à pátria: desorientados, perdidos no espaço e no tempo. Falando da sua própria condição de estrangeiro, Bauman (2005, p. 15) diz: "eu era um estrangeiro, um recém-chegado [...] uma vez recém chegado, será possível abandonar essa condição algum dia?”. Bauman analisa o que ele denomina de armadilhas e privações da autodefinição. Para ele "as pessoas em busca de identidade se vêem invariavelmente diante de uma tarefa intimidadora de 'alcançar o impossível' (BAUMAN, 2005, p. 16), o que irá implicar em se envolver em uma tarefa que se realiza na infinitude do tempo. Silvio reflete sua angústia quando se pergunta o que fazer no enorme espaço físico e simbólico que dispõe ao sair: "Primeiro é a alegria. Parece que é inacreditável. Depois vem: o que eu vou fazer? Foi rápido! Fiquei tonto com tanto espaço, com tanta coisa que eu podia fazer!”. As possibilidades próprias do ambiente externo à prisão inauguram a primeira angústia do que fazer a partir dali. Como narra Silvio, é rápida a sequência que vai da alegria à preocupação com o que fazer, dentro do sentimento maior de incredibilidade diante do fato de estar fora da prisão.

Tomar uma pinga, fumar um cigarro, olhar atentamente a rua e as mulheres. Os sujeitos, logo após o momento da saída, buscam alterar seu estado de consciência, geralmente por meio de ingestão de bebida alcoólica. A pinga, por ser mais forte, mais barata e produzida artesanalmente na prisão, é a preferida da maioria. Do consumo da cerveja estão afastados pelo tempo em que estiveram presos, daí ser essa também uma opção que implica em "matar as saudades" da bebida, mais cara e inviável para a maioria que sai das prisões sem nenhum capital, até mesmo para tomar um ônibus. Mesmo diante de outras opções, as preferências de consumo da cadeia se repetem nesse momento inicial reforçadas pelo desconhecimento das mudanças no mercado de consumo, das quais só vão se reapropriar mais tarde. Isso faz com que elejam produtos que consumiram durante o aprisionamento, geralmente levados pelas famílias através de "jumbos" - sacolas com mantimentos levadas por familiares, pessoalmente ou enviadas pelo correio.

Alguns homens, como Júlio, enfatizam a sua insegurança quanto ao uso do vocabulário de prisão e a satisfação em tomar uma cerveja. 
Irineu reforça a data em que saiu e ressalta as suas impressões. Principalmente reforça a necessidade de olhar. Outras narrativas acentuam o desligamento como estratégia durante a saída, seja por meio da bebida ou por meio de um alheamento de tudo em sua volta. De modo geral, as saídas não são programadas, o que exige que as famílias estejam preparadas para o inesperado e possam ir buscar seu familiar preso ou que o mesmo se desloque sozinho até sua casa. Algumas das instituições prisionais de São Paulo, localizadas no interior, concedem passagem até a capital onde reside o preso.

Em alguns casos, quando há mutirão do judiciário ou concessões coletivas de liberdade, as penitenciárias de uma mesma região do estado fretam um ônibus que traz vários homens libertos até a capital. Para alguns, essa é uma situação delicada por conta da possibilidade de, no mesmo ônibus, oriundos de diferentes penitenciárias, viajarem inimigos ou pessoas filiadas a facções rivais, existentes nas prisões. Muitos, mesmo que inseguros, preferem voltar só. A preocupação com a existência de inimigos na mesma prisão ou em "bondes", denominação dada aos veículos que transferem presos de uma prisão para outra, é regular nos estabelecimentos prisionais quando da entrada dos sujeitos no sistema prisional. No entanto, no momento da saída, o estabelecimento prisional, quando oferta o transporte coletivo, se exime dessa preocupação, deixando para o preso liberto o ônus de colocar a sua vida em risco ou de adquirir com recursos próprios a passagem de volta. Em Salvador, não foi verificada nenhum serviço público voltado a assistir aos que saem, pelo contrário, muitos homens saem com recursos arranjados, ao menos para o transporte, pelos que homens que ficam.

Para entender em que condições os sujeitos saem das prisões, é importante acompanhar não só esse momento específico, mas todo o processo de chegada na cidade, seja em casa, retornando para a sua família, seja para o seu meio social mais amplo, seu local de vida, a rua, seus amigos, etc. A chegada é um processo útil para compreender como se dá a integração inicial desses sujeitos, sob o ponto de vista do resgate do pertencimento a outras esferas da vida social fora da prisão, e como o aprisionamento interfere nessa retomada. Essa compreensão é valiosa no sentido de permitir entender a reconstrução identitária desses sujeitos. Partindo do princípio defendido por Bauman de que 
a identidade e pertencimento estão intimamente correlacionados, "a idéia de ter uma identidade não vai ocorrer às pessoas enquanto o pertencimento continuar sendo o seu próprio destino, uma condição sem alternativa”. (BAUMAN, 2005, p. 18)

Na prisão os sujeitos enlutam suas antigas identificações e, ao saírem, visando a sua emancipação da condição de presidiário, deveriam enlutar-se das identificações estruturadas no tempo de prisão, contando, para isso, com o apoio da família ou de profissionais, o que nem sempre acontece. A saída, como se dá, não implica necessariamente em um processo de quebra dos laços produzidos pelos sujeitos como o ambiente carcerário. Como esses laços não foram simbolicamente rompidos, o cárcere retorna a todo tempo, seja na desconfiança ou no excesso de preocupação de algumas famílias, seja no desprezo de outras pelo retorno do encarcerado, seja na sociabilidade estruturada pela estigmatização promovida pela rua, através de vizinhos que o repelem ou de sujeitos relacionados ao crime que os atraem e/ou reforçam sua identidade de delinquente.

Na saída da prisão, o tempo psíquico desses sujeitos confunde presente, passado e futuro: três estágios que a partir da experiência prisional passam a ser tangenciados por ela. A etapa da saída se constitui, portanto, tendo como passado um tempo anterior à prisão e o presente e o futuro confundidos. A prisão que era presente, ainda o é, na medida em que o futuro que se pensava para depois dela, não se concretizou. Carignato (1999) reflete para os migrantes, de forma analógica ao que se pode refletir para os ex-presos: os migrantes têm que viver em outra terra, com códigos e tempos diferentes e, para isso, diz a autora, necessitaram fazer "luto das antigas identificações". Mas o desejo do migrante é de retornar à terra natal e reencontrar nela as coisas que deixou, a partir do mesmo lugar em que elas estavam quando ele partiu. Porém, conclui a autora: nem ele é o mesmo, nem as pessoas são as mesmas - é nisso que se baseia o fracasso do retorno à terra natal.

O tempo passado na prisão, como em um exílio, é um tempo de ausências de família, dos amigos, do trabalho, dos amores, etc. A prisão é suspensa da cronologia como um não passado, entretanto, embora não percebam, sempre referenciada no presente. A saída da prisão é o início da vivência de um futuro almejado na prisão, todavia, ao chegar 
em casa, esse futuro, agora presente, se coloca em um tempo difuso entre o que se vive e o que se viveu na prisão. Eles fazem referência a um "hoje" de modo complexo, como se não acreditassem no vivido. A vivência do futuro como presente, logo na saída da prisão ou da chegada em casa, traz um sentimento de duplo vínculo: aquilo que esperavam da saída, da chegada em casa, da família, do meio, no momento em que planejavam o futuro, não considerava a força e a presença constante da prisão nesse futuro esperado.

A cidade ou o "mundão" passam, em alguns casos, a ser o espaço da competição, da falta de moral, justamente o espaço que era evitado na prisão, ou seja, o mundão passa a ser também um inferno. Inicia-se aí o processo de alternância da sua representação sobre a liberdade, a partir da consideração sobre o "mundão". A liberdade do cárcere não lhe atribuiu a liberdade de sua condição econômica e social na sociedade em geral, como ilusionariamente pensara.

A chegada em casa traz um dualismo de comportamento e de ideias, seja no mundo inteligível, seja no mundo sensível. Esse dualismo traz, na situação de fronteira, a ideia de mundos intermediários entre a prisão, o mundo vivido e presente na memória e o futuro composto por um mundo imaginário. Como conceitua Turner (1974), a fronteira é o espaço onde frequentemente se desencadeia a elaboração de um conjunto amplo de símbolos que denotam ambiguidade e transitoriedade. Esse fenômeno acontece em muitos outros grupos, tornando-os personagens do meio, da fronteira. O rito de passagem assume a ambiguidade da fronteira a ser ultrapassada e todo o risco é produzido quando ainda há uma margem entre estar preso e estar solto. Essa margem só é rompida quando o homem está definitivamente fora da prisão, reintegrado a outra cultura que não a carcerária e merecedor de um novo status. Ao contrário, aquele que permanece no "meio", na fronteira, faz com que essa ambigüidade deixe de ser uma condição transitória para se tornar um componente aderente de sua própria identidade. Assim, esses homens vivenciam e experienciam mundos paralelos. Para Bauman (2005, p. 17):

O pertencimento e a identidade não têm a solidez de uma rocha, não são garantidos por toda a vida, são bastante negociáveis e revogáveis. As decisões que o próprio individuo toma, os caminhos que percorre, a maneira como age e a determinação de se manter 
firme a tudo isso são fatores cruciais, tanto para o 'pertencimento', quanto para a identidade.

O não estar completamente no mundo da ordem ou no mundo específico da ordem prisional, faz do sujeito uma fonte de perigo, instaura a desordem e confunde os padrões, como cita Douglas (1966). O preso e o homem livre passam a convergir em um mesmo personagem, o ex-preso. Alguns deles vão ou podem ocupar esse espaço terceiro como sendo efetivamente o seu, reforçando, portanto, a sua identidade a partir dessa condição de ex-preso. Essa dualidade fronteiriça passa a ser seu território.

A fronteira é um campo que se estabelece com as interações possíveis. Conclui-se que na saída do estabelecimento prisional, como na chegada em casa, as interações e as trocas se processam de forma delicada e ambígua. A família estranha à presença do sujeito, ele estranha a casa, os hábitos, há um estranhamento com o espaço urbano, o transporte, as pessoas nas ruas. Em pouco tempo a família lhe cobra o que não tem e, portanto, não pode dar: a sua participação no orçamento familiar acrescido pela sua volta. Passam a viver no primeiro cenário de lutas que é a sua casa e os seus próximos. O segundo estágio é viver na margem das duas culturas, e o terceiro, o reforço de uma delas, seja a do mundão seja a do cárcere. A vivência da fronteira é, portanto a maior dificuldade para que o ex-preso se torne ex-ex-preso.

\section{Referências}

ADORNO, Sergio. A prisão sob a ótica de seus protagonistas: itinerário de uma pesquisa. Tempo Social, Revista de Sociologia da USP, São Paulo, v. l, n. 1, p.1-17, 1991.

. Reincidência e reincidentes, penitenciários em São Paulo,

1974-1985. Revista Brasileira de Ciências Sociais, São Paulo, v. 3, n. 9, fev. 1989.

. Sistema penitenciário no Brasil: problemas e desafios. Revista USP, São Paulo, v. 9, p. 57-64, mar./maio 1991.

ARENDT, Hannah. A condição humana. Rio de Janeiro: Forense, 1989.

BAUMAN, Zygmunt. Identidade: entrevista a Benedetto Veccho. Rio de Janeiro: Jorge Zahar, 2005. 
1998.

. O mal-estar da pós-modernidade. Rio de Janeiro: Jorge Zahar,

BECKER, Howard S. Métodos de pesquisas em ciências sociais. São Paulo: Hucitec, 1999.

BECKER, Howard S. Los extraños: socilogia de la desviacion. Buenos Aires: Editorial Tiempo Ccontemporâneo, 1971. . Métodos de pesquisas em ciências sociais. São Paulo: Hucitec, 1999.

BOSI, Ecléa. Memória e sociedade. São Paulo: Companhia das Letras, 2003.

BRASIL. Lei de execução penal. São Paulo: Saraiva, 1977.

CARDOSO, Ruth C. L. (Org.). A aventura antropológica: teoria e pesquisa. Rio de Janeiro: Paz e Terra, 1986.

CARIGNATO, T. T. Passagem para o desconhecido: um estudo psicanalítico sobre imigrações entre Brasil e Japão. 1999. Dissertação (Mestrado em Psicologia) - Programa de Pós-graduação em Psicologia, Pontifícia Universidade Católica de São Paulo, São Paulo, 1999.

CIAMPA, Antonio da Costa. A estória do Severino e a história da Severina. São Paulo: Brasiliense, 2001.

DOUGLAS, Mary. Pureza e perigo. São Paulo: Perspectiva, 1966.

DURKHEIM, E.; MAUSS, M. Algumas formas primitivas de classificação. In: MAUSS, M. Ensaios de Sociologia. São Paulo: Perspectiva, 1971.

ELIADE, Mirca. Mito do eterno retorno. São Paulo: Mercuryo, 1992.

FOUCAULT, Michel. Eu, Pierre Rivière, que degolei minha mãe, minha irmã e meu irmão... um caso de parricídio do século XX, apresentado por Michael Foucault. Rio de Janeiro: Graal, 2000.

. La impossible prisión. Barcelona: Anagrama, 1982.

. La vida de los hombres infames: ensayos dobre desviación y dominación. Buenos Ayres: Altamira Nordam Comunidade, 1993.

. Microfísica do poder. Rio de Janeiro: Graal, 1990.

. O cuidado de si. In: . História da sexualidade. Rio de Janeiro: Graal, 1985. v. 3.

. Os anormais: curso no Collége de France (1974-1975). São Paulo:

Martins Fontes, 2001.

. Vigiar e punir: nascimento da prisão. Petrópolis: Vozes, 1989. 
GEERTZ, Clifford. A interpretação das culturas. Rio de Janeiro: Livros Técnicos e Científicos, 1989.

. Nova luz sobre a antropologia. Rio de Janeiro: Jorge Zahar, 2001.

2002.

. Obras e vidas: o antropólogo como autor. Rio de Janeiro: UFRJ,

GIRARD, René. A violência e o sagrado. São Paulo: Universidade Estadual Paulista, 1990.

GOFFMAN, Erving. A representação do eu na vida cotidiana. Petrópolis: Vozes, 1999.

. Estigma: notas sobre a manipulação da identidade deteriorada. Rio de Janeiro: Koogan, 1988.

. Manicômios, prisões e conventos. São Paulo: Perspectiva, 1999.

HALBWACHS, Maurice. A memória coletiva. São Paulo: Centauro, 2004.

LEVINAS, Emmanuel. Entre nós: ensaios sobre a alteridade. Petrópolis:

Vozes, 1997.

MARIN, Isabel S. Kahn. FEBEM, família e identidade: o lugar do outro.

São Paulo: Escuta, 1999.

MEAD, George H. Espiritu, persona y sociedad: desde el punto de vista del conductismo social. Buenos Ayres: Paidos, 1972.

POLLACK, Michael. Memória e identidade social. Estudos Históricos, Rio de Janeiro, v. 5, n.10, p. 200-212, 1992.

. Memória, esquecimento, silêncio. Estudos Históricos, Rio de

Janeiro, v. 2, n. 3, p. 3-15, 1989.

THOMSON, Augusto. A questão penitenciária. Rio de Janeiro: Forense, 2002.

TURNER, V. Ritual process: the structure and anti-structure. Nova York:

Aldine de Gruyter, 1974. 


\section{Deixa eu ver sua alma- Narrativa de si como política de si em escritos de Luiz Alberto Mendes}

Denise Carrascosa

\section{Introdução}

No dia em que Luiz Alberto Mendes foi encarcerado na Casa de Detenção do Complexo do Carandiru como "primário" (e, portanto, mandado para o seu pavilhão 9), seu corpo já havia sido reincidentemente marcado por uma duríssima tecnologia disciplinar-prisional posta em prática nos juizados de menores, delegacias e DOI-CODIs ${ }^{1}$ da vida subterrânea do Estado de São Paulo entre as décadas de sessenta e setenta.

Era o ano de 1973 (estado ditatorial no Brasil) e, aos 21 anos, Mendes já fora interno do juizado de menores aos 11 ou 12 (1963 ou 1964), relatando ter ouvido de um delegado o seguinte: "Devíamos exterminar esses animaizinhos antes que se tornem um problema insolúvel para o futuro. Vai para o juizado e é provável que amanhã mesmo já esteja aí nas ruas atacando algum trabalhador”. (MENDES, 2001, p. 83)

No alojamento do juizado, depois de uma tentativa frustrada de fuga, "os funcionários pegaram pedaços de pau e bateram com

1 Destacamento de Operações de Informações do Centro de Operações de Defesa Interna - um dos aparelhos de repressão do Regime Militar Brasileiro, que funcionou como centro de aplicação de técnicas de tortura, entre os anos 1969 e 1980, 
vontade”. (MENDES, 2001, p. 84) Esta cena de castigo corporal, tendo em vista as tantas outras dos seus escritos, é narrada sem muitos detalhes:

Havia prazer neles em bater, parecia que nunca mais iriam parar. Quando decidiram que eu apanhara o suficiente, jogaram-me nu, dentro de um quartinho escuro. Estava todo quebrado, dolorido demais, querendo minha mãe. Ainda gritava por minha mãe quando me batiam, como uma criança. Adormeci, cansado, para acordar em seguida, sufocado pela água que um funcionário jogou em mim com um balde. (MENDES, 2001, p. 84-85)

No outro dia, de manhã cedo, um funcionário perguntou-lhe como estava, alegando não ter ajudado na surra. Luiz nos diz que fez que não o viu batendo. Pede suas roupas, porque morria de frio. O funcionário chama um colega que, assustado com o estado do menino, leva-o à enfermaria. Lá, ele finge estar pior do que realmente estava. Depois de três dias de enfermaria, volta ao alojamento, no qual:

Os funcionários olhavam caçadores. A vigilância redobrava em cima de mim. Ficaram me seguindo o tempo todo, não me perdiam de vista. Nem pensei mais em fugir, fiquei com o maior medo da surra que me prometiam, caso tentasse. Decidi esperar meu destino. (MENDES, 2001, p. 85)

Por uma perspectiva, os escritos de Luiz Alberto Mendes constituem reativações narrativas de algumas das constantes de sua vida que podemos ler no episódio resenhado acima: aprisionamento, fuga, castigo corporal, repetida sensação de vigilância e medo.

Tais elementos nos chegam mediados por uma decisão: a escrita da própria vida, tomada aos trinta e seis anos (1988) numa cela individual da Penitenciária do Estado de São Paulo, na qual Mendes fora novamente preso quatro anos depois de ter fugido.

Tendo em vista dois de seus livros e um conto, resultantes desse esforço de escrita de si mesmo (respectivamente Memórias de um sobrevivente, Às cegas e Cela forte), interessa-me, aqui, analisar as marcas deixadas pela dura tecnologia disciplinar-prisional vivida/ narrada, sobre a voz de Luiz Alberto Mendes e, mais ainda, pensar seus investimentos discursivos, estratégicos e, portanto, políticos no sentido de um retrabalho ativo sobre tais marcas, o que chamo (com clara extração foucaultiana), respectivamente: técnicas e políticas de si. 


\section{A prisão é uma coisa demasiado estúpida ${ }^{2}$}

Depois de muito tempo - mas o que era "muito tempo"? - comecei a procurar por mim mesmo na pessoa que dormia e acordava no chão daquele lugar odioso cuja imutabilidade impunha-se como prova de que não havia - nunca houvera - outros lugares. (VELOSO, 2004, p. 359, grifo nosso)

A forma-prisão como mecanismo disciplinar opera, entre outros efeitos, uma espécie de ruptura física e simbólica entre o sujeito aprisionado e suas unidades de atribuição de significado a si mesmo como sujeito sócio-histórico: o lugar onde mora, sua família, seu circuito de relações pessoais, suas ocupações, a organização temporal da rotina, as possibilidades de deslocamento espacial, o seu corpo.

Não é sem propósito que os relatos de indivíduos presos mencionam correspondências, encomendas (roupas, comidas, cigarros), "bondes", ${ }^{3}$ visitas de amigos, familiares e visitas íntimas sob uma atmosfera mista de ansiedade e alívio da tensão do encarceramento, a funcionar como válvulas de escape e reconexão com um mundo real.

Paradoxalmente, entretanto, dispositivos prisionais, como o isolamento em uma cela individual por vários dias consecutivos, têm a potência de reinscrever, em uma zona de tensão, a relação do indivíduo para consigo próprio, para com um espaço a si atribuível de "interioridade", "consciência”, "essência” ou "alma” - noções socialmente recorrentes quando se pensa uma unidade estável, imutável, eterna e bem guardada dentro de cada corpo individual, que o anima e torna transcendentalmente diverso dos demais. Se lermos Aristóteles nesse sentido, alguns fragmentos de sua Metafísica podem tornar-se bem atuais:

2 Da carta de Antônio Gramsci endereçada a "Querida Mamãe", do "Cárcere de Milão" em 12 de março de 1928: "A prisão é uma coisa demasiado estúpida; mas para mim seria ainda pior a desonra por fraqueza moral e por velhacaria. Por isso, a senhora não deve se alarmar e magoar muito, nem pensar nunca que eu esteja abatido e desesperado. Deve ter paciência e, em quaisquer circunstâncias, não acreditar nas lorotas que possam publicar a meu respeito. Espero que já tenha recebido todas as minhas cartas precedentes. Renovo os votos mais afetuosos pelo seu aniversário e abraço-a ternamente. Nino". (GRAMSCI, 1978, p. 108)

3 O "bonde" é a chegada de novos detentos a uma instituição prisional, que sempre anuncia notícias do mundo exterior, e é aguardado com ansiedade pelos que lá se encontram presos (a questão recorrente dos celulares nos presídios brasileiros, tratada midiaticamente apenas do ponto de vista da instrumentalização do crime, pode ser pensada como sintomática da ruptura físico-simbólica de que trato aqui). 
Parece, além disso, impossível que existam separadamente a substância e aquilo de que ela é substância: neste caso, as idéias, que são as substâncias das coisas, como existiriam separadas delas? No Fédon, porém, afirma-se que as idéias são causas do ser e do devir. Todavia, ainda que as idéias existam, os seres que delas participam não são gerados se não houver um primeiro motor. (ARISTÓTELES, 1979, p. 32)

O "si" do olhar do sujeito encarcerado para si mesmo passa a constituir uma unidade complexa formada por aquilo que resta de "mim" quando absolutamente despido de tudo que me fazia significar como sujeito e, ao mesmo tempo, por aquilo que sempre esteve em "mim" e que, entretanto, eu não conheço, a minha "substância". O isolamento carcerário pode, assim, instaurar um movimento de aproximação do sujeito com esse espaço de imaginária interioridade chamado, entre outros epítetos, de "alma".

No conto Cela forte, Luiz Alberto Mendes narra que, em maio de 1973, aguardava a hora da contagem dos presos, deitado em sua cela, lendo Luzia homem "como todo preso, pronto para ser contado. Almas concretas, densas até os ossos” (MENDES, 2005b, p. 109), quando cerca de dez guardas armados de cano de ferro invadiram sua cela, revistaram-na e mandaram que ele abaixasse o calção, levantasse "o saco" e agachasse três vezes:

Eu parecia uma mola para baixo e para cima. Provavelmente pensavam que escondesse uma metralhadora, ou sei lá o que, no cu. Era extremamente humilhante. Me encolhi, com meu exército de palavras desmantelado e minha alma menos minha. (MENDES, 2005b, p. 109)

Parece haver aí enunciado um espaço híbrido de relações de força entre aquilo que lhe resta de próprio em uma cena de intervenção quase absoluta em seu espaço individual (cela/corpo) - "minha alma" - e um lugar de seqüestro (potencial cativeiro desta alma): "alma menos minha”.

Em sua pesquisa sobre a história das prisões, Michel Foucault afirma que a punição penal se metamorfoseia modernamente (século XVIII) a partir de uma penalidade supliciante do corpo em direção a uma "penalidade do incorporal": 
Se não é mais ao corpo que se dirige a punição, em suas formas mais duras, sobre o que, então, se exerce? [...] Pois não é mais o corpo, é a alma. À expiação que tripudia sobre o corpo deve suceder um castigo que atue, profundamente, sobre o coração, o intelecto, a vontade, as disposições. (FOUCAULT, 2005, p. 18)

No entanto, se por um instante pudermos pensar em articulação do investimento simultâneo do sistema prisional moderno sobre o corpo do preso e sobre sua "alma" de modo supliciante (referido pelo mesmo texto foucaultiano), este seria o instante do "isolamento" como técnica de castigo físico e simbólico (nas "Isoladas", "Celas Fortes" e "Masmorras" do sistema).

E cela-forte, ali, era forte mesmo. Ficava-se isolado em uma cela, só de calção, sem contato com ninguém. E ainda havia a cafua. Um quarto escuro e todo trancado, isolado da prisão. Esse era o lugar que todos mais temiam. A escuridão apavorava. (MENDES, 2001, p. 159)

O pânico se apossou de mim. A cela estava nua como eu. Não havia nada ali. As paredes vertiam água. O chão era de caquinhos de cerâmica, geladíssimo. O tempo estava gelado, eu já tremia de medo e frio desde os primeiros instantes ali. (MENDES, 2001, p. 429)

Apenas quando me deitei, esgotado de cansaço, no chão gelado, é que fui estar plenamente consciente de mim. Senti o corpo e o espírito quebrados. (MENDES, 2001, p. 419)

Fiquei apenas eu ali. Foi difícil a solidão, cheguei a chorar várias vezes e ainda querer minha mãe. Os anos haviam se passado, e eu ainda era um menino querendo sua mãe. (MENDES, 2001, p. 420)

Um dos efeitos gerados por essa técnica de despojamento de tudo que faça o indivíduo significar socialmente, inclusive de sua relação simbólica com o próprio corpo, constitui a potencialização do sentimento de solidão. O sujeito, fora de um tempo e de um espaço que lhe geram um olhar de reconhecimento de si mediado pela vida social, procura um "si" outro, um "si" em silêncio absoluto de outras vozes que não sejam a sua própria.

Atravessada por uma série de experiências de isolamento físico, a voz narrativa de Mendes, na construção de um personagem para si, é reiteradamente marcada por esta referência: a solidão, retraçada ao período de sua infância: 
Uma das lembranças mais doloridas era a solidão em que eu vivia em casa e na creche. Tive muito poucos amigos [...] Muitas vezes minha mãe se atrasava, era longe de casa a creche, eu me desesperava. Ficava ali no portão chorando, sentindo-me miseravelmente abandonado. (MENDES, 2001, p. 20)

Esta sensação de solidão intensa, como marca de uma voz que busca uma espécie de "si" em uma história de vida pessoal, articula-se narrativamente a certos medos que posicionam o personagem-criança em um cenário de insegurança existencial: "Esse era o maior medo de minha mãe: o despejo. Não ter onde morar. Vivia apavorada com tal possibilidade, que, diga-se de passagem, era bem concreta. Uma ameaça constante, mensal”. (MENDES, 2001, p. 20)

A figura paterna, responsável social pela manutenção econômica da família - o menino Luiz, a mãe que cuidava da casa e o pai que oscilava entre o emprego e o desemprego - é repetidamente mostrado em cenas como a que segue:

Ele chegava, minha mãe esquentava a comida. Mal começava a comer e já desmaiava de cara no prato, de tão bêbado que estava. Eu, pequeno, dona Eida, pequena também, tínhamos que arrastá-lo da cozinha até o quarto. Depois, com toda dificuldade do mundo, colocá-lo na cama, despi-lo e cobri-lo. Era muito pesado e ficava dando tapas no ar, semiconsciente. Quando um deles pegava em um de nós, voávamos longe. (MENDES, 2001, p. 21)

À força, muitas vezes truculenta do pai, opõe-se o corpo frágil da mãe, fonte da tênue zona de confiança e segurança afetiva que é delineada pela narrativa:

Eu e dona Eida éramos muito apegados. Sentíamos que, na verdade, só tínhamos um ao outro no mundo. Ele não participava desse círculo fechado. Jamais fez por merecer. Minha mãe escondia muitas de minhas traquinagens. Sabia que, se ele soubesse, eu seria massacrado. Aquela mulher era muito delicada, extremamente feminina, eu a amava a ponto de chorar às vezes, só de pensar nela. Fisicamente era muito pequena: tivera meningite aos doze anos e não crescera mais. (MENDES, 2001, p. 20)

Esta figura materna funciona sempre como um débil vínculo entre o sujeito Luiz Alberto Mendes e o fora do mundo do "crime". Nas margens da ideia de delinquência como geradora da identidade do narrador que se escreve, dona Eida aparece sempre para lhe visitar 
quando está preso, levar roupas, dinheiro, notícias do mundo exterior, carinho e vontades de entrega a uma vida social estável, com emprego, esposa e filhos.

Algumas das muitas mulheres que são postas em cenas diversas ao longo da vida de Mendes reativam essa frágil zona de segurança afetiva, que parece ser sempre intensa em termos de atividades sísmicas, sempre desenhada como se fosse chão de gelo fino sob seus pés, prestes a rachar. A última dessas mulheres que nos é apresentada por seus escritos é Magda:

Chegava a hora de pensar em ser honesto. Não importava que todos roubassem. Eu não queria mais isso pra mim. Queria um pacto de paz com o mundo. Precisava de paz para amar e ser feliz. Queria ter algo além de palavra e coração para oferecer à namorada. Magda me levava a pensar na honestidade como princípio. Ela queria um companheiro que procedesse dentro de seus padrões. Eu queria ter orgulho de vencer, superar e ultrapassar. (MENDES, 2005a, p. 253)

Esse espaço intervalar em uma vida marcada pelo signo da delinquência também funciona em três ou quatro cenas de encontro com seu pai. Ao completar 18 anos, preso em um Instituto de internamento para menores infratores em Mogi-Mirim, Mendes afirma odiar o pai, que seria o responsável por sua manutenção ali, cogitando, inclusive a possibilidade de matá-lo: “Só matando-o, então, me livraria?” (MENDES, 2001, p. 187) Dois parágrafos depois, a voz narrativa nos fala da visita desse pai como um fato inédito e surpreendente até aquele ponto de sua vida:

Pedi a benção de meu pai, beijei sua mão forte e grossa. Naquele momento eu o amei, senti nele um pai, pela primeira vez em minha vida. Havia segurança, força e autoridade nele, e aquilo me emocionava demais. Eu jamais soubera o que era um pai mesmo. (MENDES, 2001, p. 187)

A essas radicais oscilações de atitudes e desejos do sujeito em espaços curtíssimos de tempo, sejam os do narrado ou da própria narrativa, podemos conectar os escritos de epílogo de Memórias de um sobrevivente e Às cegas, na medida em que funcionam como um olhar retroativo sobre e, de certa forma, reativador da articulação entre viva vivida e vida escrita: 
Passaram-se mais de vinte anos do final do relato que fiz de minha vida. Muita água rolou por baixo da ponte, nesse tempo. Daria para fazer um novo livro. Talvez até venha a fazê-lo, não se sabe do futuro. A intenção é escrever sempre e para sempre. Mas não sei... a vida me ensinou a nunca esperar fluidez contínua, e sim descontinuidade, tanto na vida de cada um, como na de todos em geral. (MENDES, 2001, p. 471)

Por exemplo, Magda não permaneceu. Me abandonou, mais uma vez. Motivos? Os mesmos de sempre. Queria presença, e eu não podia. Queria uma segurança que nunca tive nem pra mim. (MENDES, 2005a, p. 355).

A relação (narrativa) desse sujeito com os fatos de sua própria vida (elementos selecionados, formas de organização e auto-análise) parece marcada, desse modo, por uma constante sensação de insegurança em frequência com a solidão como efeito do isolamento prisional, a se projetar tanto sobre a subjetividade descontínua que resulta da narrativa, quanto sobre a dinâmica narrativa que a engendra como técnica de subjetivação. Isto é: parece atuante sobre os escritos de Luiz Alberto Mendes um certo dispositivo de atenuação das conexões entre o que ele procura construir como um lugar para "si" e outras unidades sociais de atribuição de sentido ao sujeito, o que resulta em uma instabilidade constante desse mesmo "lugar para si" e de seu processo de construção: subjetivação via narrativa da própria vida.

Se pensado esse processo de subjetivação sob o enfoque que dá Anthony Giddens à "construção do eu" como um potencial "conseqüência da modernidade" ou ao que chama de "modernidade radicalizada" como possibilitadora de "processos ativos de auto-identidade", através das relações de confiança em seus "sistemas abstratos" e "mutualidade" e "intimidade" das "relações de confiança pessoal" (GIDDENS, 1991, p. 116-117) talvez possamos hipotetizar que a técnica punitiva do isolamento do preso engendra uma espécie de curto-circuito nos processos modernos de construção de um sentido estável para o "eu”, na medida em que instaura a procura de um "si mesmo" mediada pela solidão, pela violenta ruptura com elementos sociorreferenciais mais estáveis de produção de sentido.

Operando sob esta ótica, os escritos de Luiz Alberto Mendes podem ser lidos como a escolha de uma forma, ou melhor, uma técnica, talvez ainda uma política para lidar com uma dupla e violenta, porque 
abrupta, pressão da tecnologia disciplinar-prisional sobre o sujeito à margem social: o isolamento como sequestro das possibilidades sociais de atribuição de um sentido mais estável a si mesmo, bem como intensificação de uma relação com um lugar a ser construído para esse "si”, mediada por uma solidão e instabilidade profundas.

Na dinâmica oscilante entre a técnica de despersonalização que implica a superlotação das celas e a de individuação do isolamento, ambas as experiências narradas por Luiz Alberto Mendes, o medo e a intensificação do pensamento são constantemente referidos:

$\mathrm{Na}$ cela individual, com tempo para refletir, aos poucos minha mente começou a entrar em parafuso [...] No tambor das lembranças, as palavras disparavam irreversíveis. Eu sentia muito medo de ser incontrolável, irracional. Medo de que me dominar estivesse além de minhas possibilidades. (MENDES, 2005a, p. 236)

O ano era o de 1988 e Luiz Alberto Mendes estava em uma cela individual da Penitenciária do Estado de São Paulo, frustrado por não ter aproveitado a oportunidade de formar-se pela PUC-SP em Direito ou História, de não estar fora da prisão, "[...] vivendo em sociedade. Casado talvez, com filhos, num lar. Minha mãe feliz comigo”. (MENDES, 2005a, p. 236) A cena que segue parece um ponto fundamental o suficiente para justificar a longa citação:

Comecei a ver minha vida como uma série de conseqüências. As causas, eu não percebia. Quando dava por mim, já estava nas conseqüências. A verdade que devia ser assumida: eu não tinha controle sobre a minha existência. Vivia uma roda-viva, cujas conseqüências desencadeavam causas que geravam outras conseqüências. E eu, no meio, em espaços reduzidos, travado. Lutando, lutando para boiar na tábua escorregadia do meu presente. Passado movediço, futuro ignorado.

Eu queria tornar compreensível à razão esse processo. Refletia, vasculhava e me perdia em pensamentos capilares. Busquei, com unhas e dentes, um método. Durante o tempo em que estudei, o melhor método para aprender fora a escrita. Eu escrevia tudo o que entendia e assim assimilava definitivamente.

A idéia de escrever minha vida foi automática. Escrever para mim mesmo, para ninguém mais. Sem receio de ser punido ou censurado. Precisava entender o que havia acontecido. Era isso. Iria escrever minha história para me conhecer. (MENDES, 2005a, p. 237) 
Neste ponto de Às cegas, Luiz Alberto Mendes coloca em narrativa uma cena de gênese de Memórias de um sobrevivente, que teria sido escrito durante cinco meses de sofrido "mergulho em seu passado", a partir, inclusive, de notas que tomara a sua mãe sobre a história de seus pais e sua infância. "Descobre", assim, que fora criado "na base do chicote", uma criança "melancólica, solitária e muito infeliz": "via-me na figura daquele menino e me desconhecia. Às vezes ele era eu mesmo, e chorava me descrevendo, com profunda piedade daquele garoto”. (MENDES, 2005a, p. 238)

Na adolescência, passara "fome, frio, solidão, terror, aventura, sexo, vaidades e loucuras inexplicáveis. Revivi um tumulto interior impossível de ser controlado ou contido nas quatro paredes da minha cela”. (MENDES, 2005a, p. 238)

A partir da referência à fase em que começara a "ser preso seriamente”, menciona "Torturas e sevícias. Espancamentos, estiletadas, borrachadas, nas prisões para menores infratores". (MENDES, 2005a, p. 239) À "fase” das armas, assaltos e drogas, seguem-se a tortura sistemática, a chegada à Casa de Detenção, à Penitenciária do Estado e a experiência da cela-forte. Na seqüência, aparecem "o maior dos amigos" - Henrique Moreno, que lhe leva à paixão pela literatura - e "o primeiro amor verdadeiro" - Eneida, que lhe faz estudar com "seriedade, responsabilidade”. (MENDES, 2005a, p. 239)

A retomada em flashes dos cinco meses de escrita de uma parcela de sua vida - "minha história até os vinte e sete anos" (MENDES, 2005a, p. 241) - opera pela narrativização das reações e motivações de um sujeito encarcerado na trajetória de aproximação a uma certa "verdade de si” que só passa a lhe ser acessível pelo "método" da escrita. Em Às cegas, o Luiz Alberto Mendes-ladrão-detento torna-se o Luiz Alberto Mendes-escritor-senhor-de-sua-existência, no espaço desse trecho narrativo e em suas extrapolações: "Cada linha foi extraída como que com as unhas, de grossas paredes. Parei muitas vezes. Ficava dias sem escrever. Em recuperação. Quando me sentia forte, retomava”. (MENDES, 2005a, p. 239)

Contracenam, ali, um sujeito oprimido/produzido por uma trajetória-tecnologia de produção social de marginalização e um sujeito que toma consciência dela via escrita de si. Contra o pano de fundo de uma cela individual na Penitenciária do Estado, dois personagens 
se projetam: o personagem-resultado caótico de uma vida desregrada e o personagem-atividade que decide impor-se um método de domínio de si, que levasse a uma aprendizagem sobre si mesmo, a partir do controle dos tempos vividos/a viver - passado, presente, futuro, de suas relações entre causas e conseqüências, ou seja, um método narrativo de escrita/aprendizagem de si.

Quanto à escrita como técnica de produção de uma identidade para si, em uma série de estudos sobre textos regulamentadores de práticas da cultura greco-romana circulantes nos dois primeiros séculos da chamada "era cristã", Michel Foucault examina aquilo que chama de "cultura de si" como motivada, entre outros fatores, por uma necessidade de aprendizagem de exercício de domínio sobre si diante dos acontecimentos. De uma passagem extraída de Sêneca, que cita Demétrius, sublinha:

[...] devemos nos exercitar como faz um atleta; este não aprende todos os movimentos possíveis, não tenta fazer proezas inúteis; prepara-se para alguns movimentos necessários à luta para triunfar sobre seus adversários [...] Como um bom lutador, devemos aprender exclusivamente aquilo que nos permitirá resistir aos acontecimentos que se podem produzir; devemos aprender a não nos deixar perturbar por eles, a não nos deixar levar pelas emoções que eles poderiam suscitar em nós. (FOUCAULT, 1997, p. 126-127)

Para fazer face à potencialidade futura dos acontecimentos, seria preciso dispor de um equipamento de "discursos verdadeiros" sobre o mundo que estivesse sempre à mão, fixado ao "espírito", constituindo métodos dessa apropriação: exercícios de memorização do que fora aprendido, a boa escuta como direcionamento da atenção e a escrita pessoal em "notas das leituras, conversas, reflexões que se ouvem ou que se fazem a si mesmo". (FOUCAULT, 1997, p. 127-129)

A escrita como exercício constituiria um "treino de si por si mesmo”, uma forma de manutenção dos pensamentos noite e dia à disposição, postos como objeto de conversações consigo mesmo e com os outros, um trabalho do pensamento sobre ele mesmo a reativar aquilo que sabe a fim de enfrentar o real, mediante uma "elaboração dos discursos recebidos e reconhecidos como verdadeiros em princípios racionais de ação", função, enfim, na expressão extraída de Plutarco, etopoiética. (FOUCAULT, 2004b, p. 146-147) 
Se posto entre parêntesis o hiato temporal que nos separa historicamente dos dois primeiros séculos do império romano, poderíamos afirmar que, em Às cegas, Luiz Alberto Mendes apresenta-se como um personagem que pratica esse exercício de si como técnica de produção ativa de uma identidade:

$\mathrm{Na}$ época da escravidão, os africanos, depois de um tempo nas fazendas e engenhos, construíam uma identidade, além da de escravos. Então eram ferreiros, mestres de engenho, domadores [...]. O mesmo se dá com alguns de nós. Criamos uma identidade além da de presos. Então somos escriturários, professores, marceneiros, pedreiros, encanadores $[\ldots]$

Essa a minha diferença. Eu era alguém na multidão. Fazia exercícios de escrita elaborando textos. (MENDES, 2005a, p. 276)

A "verdade narrativa" do "eu" que resulta do processo de escrita de si é convertida em um ethos de ação potencialmente geradora de uma identidade a si para confronto com o seu real: o real da solidão como dispositivo de dissolução subjetiva do preso e, ao mesmo tempo, como técnica de suscetibilização à assunção da posição discursiva de "preso".

Em face dessa relação narrativa de si para consigo mesmo, do exercício encenado e estratégico de um controle sobre sua própria identidade, é que procuro pensar técnicas que atuam em conexão com a "escrita de si” de Luiz Alberto Mendes, tomada como flagrante de relações de força entre técnicas de sujeição do criminoso-detento e técnicas ativas, portanto políticas, de subjetivação.

Se pensarmos, com auxílio Lyotard (2004), as noções de "modernidade" e "pós-modernidade" como espaços narrativos ${ }^{4}$ e, para além dessa idéia, como espaços narrativos que habitamos com nossos corpos e nossos hábitos, podemos exercitar a idéia do sujeito como corpo que procura uma casa, mesmo que em constante reforma.

O "sujeito descentrado" da pós-modernidade, como conceito (HALL, 2003, p. 46), opera pela ideia de uma precariedade constante

4 A teorização de Jean-François Lyotard sobre a "condição pós-moderna" tem como uma de suas idéias mais difundidas a do declínio dos grandes relatos e de seu poder unificador e legitimador na cultura contemporânea da sociedade pós-industrial, que Lyotard chama de “cultura pós-moderna”. Quanto ao problema do sujeito como elemento desta cultura, Lyotard propõe: "Nesta disseminação dos jogos de linguagem, é o próprio sujeito social que parece dissolver-se. O vínculo social é de linguagem, mas ele não é constituído de uma única fibra.é uma tecitura onde se cruzam pelo menos dois tipos, na realidade um número indeterminado de jogos de linguagem que obedecem a regras diferentes". (LYOTARD, 2004, p. 73) 
das narrativas que o atravessam. No entanto, para os sujeitos produzidos pela tecnologia discursiva que gera a posição de sujeito "criminoso" potente para interpelar o indivíduo através de suas próprias práticas de si e pela tecnologia disciplinar-prisional, que atravessa o detento com isolamento, tortura do corpo e vigilância, para esse sujeito que é interpelado a produzir-se a si na injunção criminoso-detento, construir, ter uma casa feita de narrativas do eu é um gesto no mínimo, político. Constitui uma política de si, uma política de vida.

Como já proposto anteriormente, a potência de interpelação da ideia de "criminoso" que, olhada de perto, também é narrativamente formulada, constrói uma posição discursiva que pode servir como lugar a ser ocupado pelo indivíduo que vive nas margens da ordem social, tanto do ponto de vista econômico, quanto histórico-cultural. Esta ideia de "sujeito criminoso" como condição estável a se encaixar sobre estes indivíduos pode ser pensada como um certo tipo de tecnologia de si potencialmente produtora de sujeitos socialmente "marginais" que se identificam com esta "condição", executando performances sociais em acordo com seus jogos discursivos.

Já as "técnicas de si" investidas contra a articulação corpo/alma do indivíduo preso remetem seus processos de subjetivação para uma zona "marginal", aqui usada no sentido derridiano de "margens" como "tecido de diferenças de forças sem nenhum centro de referência presente”, mas também como "uma inesgotável reserva". (DERRIDA, 1991, p. 25-26) Nesse sentido, o isolamento e a tortura do corpo, por exemplo, parecem funcionar como uma instauração de uma possibilidade de relação com si mesmo nessa zona de "margens", posto que desmembrada dos elementos que fazem o sujeito significar socialmente e a si mesmo.

Visto o problema a partir dessas perspectivas, a apropriação dessas técnicas diferencialmente "marginalizantes" da relação de um indivíduo com o movimento de produção de uma condição de sujeito para si e seu uso como uma "política de si”, de forma ativa, pode significar uma pressão pontual sobre a produção de sujeitos "abjetos" do ponto de vista social e simbólico, a forçar, para usar o pensamento de Judith Butler, "uma rearticulação radical daquilo que pode ser legitimamente considerado como corpos que pesam, como formas de viver que contam como "vida", como vidas que vale a pena proteger, como vidas que 
vale a pena salvar, como vidas que vale a pena prantear”. (BUTLER, 2001, p. 171)

Para citar Canclini quando fala de um outro quadro de "marginalização", a dos imigrantes e sua condição intercultural e transnacional: "Para eles, ser sujeito tem a ver com a busca de novas formas de pertencer, ter direitos e enfrentar violências". (CANCLINI, 2005, p. 205)

A partir da encenação de um eu esfacelado, produzido nas margens pelas técnicas que promovem uma relação dele consigo mesmo, parece que Luiz Alberto Mendes constrói para si uma casa feita de narrativas que lhe emprestam, para além de uma identidade provisória, uma aprendizagem de si potente para que possa ter à mão a sua própria "alma" - "alma como algo de móvel [...] algo que pode ser agitado, atingível pelo exterior”. (FOUCAULT, 2004a, p. 59)

Se assistirmos, por este viés, a entrevista de Mendes, já em liberdade, no programa Provocações, exibido pela TVE em 2007, nos chamará atenção o fato de que, à investida de Antônio Abujamra sobre uma possível auto-definição, Luiz Alberto Mendes dispara sem pausas:

Eu sou o produto dos meus fracassos. Eu fracassei a minha vida toda. Esses fracassos foram me construindo. Nós somos a somatória do que fizemos de nós. Eu fui me construindo através daquilo que eu tentei e não consegui. E chega um ponto que eu tenho e consigo. A vontade é imperiosa. Tudo a que eu me dediquei com vontade, eu cheguei. Eu acreditei em mim. Quando eu comecei a acreditar em mim, eu resolvi minha vida. (MENDES, 2007)

A escrita de si vista como técnica de produzir-se, de ter-se a si mesmo, no âmbito operacional da subjetivação, passa por uma relação de aprendizado útil de si que potencialize o uso estratégico de uma identidade, ainda que provisória, desterritorializada narrativamente.

Ambos os epílogos dos livros que aqui foram lidos, Memórias de um sobrevivente e Às cegas, tratam desse aprendizado: "Aprendi algumas coisas sobre mim"; (MENDES, 2001, p. 474) "Aprendemos sozinhos a nos virar diante da dor, cada um a seu modo"; (MENDES, 2001 p. 475) "Claro que há mazelas, hábitos e nervos em frangalhos, ninguém vive o que vivi impunemente”; (MENDES, 2001, p. 477) "Há uma tristeza profunda. Constato que o Brasil evoluiu muito da minha infância e adolescência até agora. Mas, em termos sociais, parece que as coisas continuam as mesmas”; MENDES, 2001, p. 477) “[...] mas 
também não vou mais seguir caminhos que já se provaram - exaustivamente - de dor. Mas também não vou dar mole, quero mais que simplesmente estar vivo (MENDES, 2001, p. 478) e, finalmente:

Vivi, e num mundo de homens estilhaçados. O medo permeava, e tinha cheiro de flores molhadas, surdamente pisadas à porta de cemitérios. Mas mesmo assim existi, e com intensidade.

A cada momento signifiquei de alguma maneira. (MENDES, 2005a, p. 356)

O aprendizado mediado pelo processo de escrita de si, a partir dos fragmentos selecionados acima, não constitui apenas um aprender com a memória narrativa do passado para agir no presente, consiste ainda um significar diferencial, uma possibilidade de produzir-se a si mesmo como sujeito que existe diferencialmente. Nesse sentido, a escrita de si funciona como "método" (a palavra é do próprio Mendes) de subjetivação ativa, de produção de uma "alma” escrita que pode ser lida, apesar de suas desterritorializações e por conta delas.

Pois, o fictício que comporta a ideia de sujeito segundo Nietzsche - "Não há nem espírito, nem razão, nem pensamento, nem consciência, nem alma, nem vontade, nem verdade: estas são simplesmente ficções inutilizáveis" (NIETZSCHE, 2005, p. 238) - pode vir a ser utilizável politicamente pela autoprodução de um indivíduo que, ainda que pontual e estrategicamente, possa tornar-se senhor de si, o "homem bravo" que aparece, por exemplo, na Ética aristotélica.

[...] Porque, exatamente como os membros paralisados se voltam para a esquerda quando procuramos movê-los para a direita, a mesma coisa sucede na alma: os impulsos dos incontinentes movem-se em direções contrárias. Com uma diferença, porém: enquanto, no corpo, vemos aquilo que se desvia na direção certa, na alma não podemos vê-lo.

Apesar disso, devemos admitir que também na alma existe qualquer coisa contrária ao princípio racional, qualquer coisa que lhe resiste e se opõe a ele. Em que sentido esse elemento se distingue dos outros, é uma questão que não nos interessa. Nem sequer parece ele participar de um princípio racional, como dissemos. Seja como for, no homem continente ele obedece ao referido princípio; e é de presumir que no temperante e no bravo seja mais obediente ainda, pois em tais homens ele fala, a respeito de todas as coisas, com a mesma voz que o princípio racional. (ARISTÓTELES, 1979, p. 64) 
"Com uma diferença, porém": o homem "bravo" que se faz ler como resultante dos escritos de Luiz Alberto Mendes, diversamente daquele que exerce um domínio central e absoluto sobre as linhas de fuga de sua "alma-substância”, passa a "ser" em narrativa, em processo, em deslocamento contínuo.

A contrapelo da operação de invenção da "alma" do sujeito "criminoso-hediondo", resultado de um "ser" irremediavelmente preso nas malhas discursivas e tecnológicas do poder de marginalização, a escrita de si, a partir dos escritos de Luiz Alberto Mendes, pode ser pensada contemporaneamente como política de si" na medida de sua dinâmica como conjunto de dispositivos a engendrar a produção ativa do sujeito, dentre os quais: a) a aprendizagem estratégica das técnicas de sujeição das relações de poder; b) a instauração de relações dinâmicas nas porosidades que separam e conectam narrativamente "presente" e "passado", no sentido de uma potencialização do presente que se projete sobre o processo de subjetivação; c) a gestualidade de encenação de um sujeito que se expressa no conjunto de posicionamentos discursivos potente para elidir o efeito de dissolução das operações marginalizantes.

Neste ponto, portanto, podemos pensar a narrativa de si, enquanto política de si, como uma das técnicas de subjetivação possíveis no âmbito dos vetores de força que atravessam os indivíduos, na medida em que operacionaliza a sua relação com uma série de pontos a serem ocupados nos espaços sociais de gestos, idéias, atitudes, pensamentos, em uma palavra: performances que os tornam plausíveis como sujeito.

Disso resulta conseguirmos pensar a ideia de sujeito, enquanto resultante do processo de escrita de si como uma zona de intensidades legível, conjunto de gestualidades e embates visíveis, contornável pelo gesto narrativo e pela nomeação autoral: "Aqui, apenas conto o que vivenciei. Não é testemunho ou tentativa de justificar. O fato é que sou o que vivi”. (MENDES, 2005a, p. 356, grifo nosso)

A injunção entre "contar" e "ser" engendra, assim, nos processos técnico-políticos da produção de "si”, uma alma-superfície que se deixa ver, que se deixa tocar, como espaço difuso, estratégico, fugidio, entretanto existente, de um indivíduo que se produz ativamente nas "margens" e para além delas. 


\section{Referências}

ARISTÓTELES. Metafísica: livro I e livro II; Ética a Nicômaco, Poética.

Tradução Vicenzo Cocco et al. São Paulo: Abril Cultural, 1979. (Coleção Os Pensadores).

BUTLER, Judith. Bodies that matter: on the discursive limits of "sex". New York, London: Routledge, 1993.

. Corpos que pesam: sobre os limites discursivos do "sexo". In: LOURO, Guacira Lopes (Org.). O corpo educado: pedagogias da sexualidade. Tradução Tomaz Tadeu da Silva. 2.ed. Belo Horizonte: Autêntica, 2001.

CANCLINI, Nestor García. Diferentes, desiguais e desconectados. Tradução Luiz Sérgio Henriques. Rio de Janeiro: UFRJ, 2005.

DERRIDA, Jacques. Margens da filosofia. Tradução Joaquim Torres Costa e Antônio M. Magalhães. Campinas, São Paulo: Papirus, 1991.

FOUCAULT, Michel. A hermenêutica do sujeito. Tradução Márcio Alves da Fonseca et al. São Paulo: Martins Fontes, 2004a.

. Ética, sexualidade, política. Tradução Elisa Monteiro et al. Rio de Janeiro: Forense Universitária, 2004b.

. Resumo dos Cursos do Collège de France (1970-1982). Tradução

Andréa Daher. Rio de Janeiro: Jorge Zahar, 1997. 2005.

. Vigiar e punir: nascimento da prisão. 30. ed. Petrópolis: Vozes,

GIDDENS, Anthony. As conseqüências da modernidade. Tradução Raul Fiker. São Paulo: UNESP, 1991.

GRAMSCI, Antônio. Cartas do cárcere. Tradução Noênio Spínola. 2. ed. Rio de Janeiro: Civilização Brasileira, 1978.

HALL, Stuart. A identidade cultural na pós-modernidade. Tradução Tomaz Tadeu da Silva et al. 7. ed. Rio de Janeiro: DP\&A, 2003.

LYOTARD, Jean-François. A condição pós-moderna. Tradução Ricardo Corrêa Barbosa. 8. ed. Rio de Janeiro: José Olympio, 2004.

MENDES, Luiz Alberto. Às cegas. São Paulo: Cia das Letras, 2005a. . Cela forte. In: FERRÉZ (Org.). Literatura marginal: talentos da escrita periférica. Rio de Janeiro: Agir, 2005b.

MENDES, Luiz Alberto. Entrevista. In: Provocações. Direção Antônio Abujamra) Programas 345 e 346, exibidos pela TVE em 07 nov. 2007 e 14 nov. 2007. 
. Memórias de um sobrevivente. São Paulo: Cia das Letras, 2001.

NIETZSCHE, Friedrich. Vontade de potência: parte 2. Tradução Mário D. Ferreira Santos. São Paulo: Escala, 2005. (Coleção Mestres Pensadores).

VELOSO, Caetano. Verdade tropical. São Paulo: Cia das Letras, 2004. 


\section{Sobre os autores}

\section{ANTÔNIO CARLOS CRUZ FREIRE}

Médico Psiquiatra

Professor da Escola Bahiana de Medicina e Saúde Pública (EBMSP)

Membro do Laboratório Interdisciplinar de Pesquisa em Autismo

\section{ANTÓNIO PEDRO ANDRADE DORES}

Professor Auxiliar com Agregação do Departamento de Sociologia

e do Centro de Investigação e Estudos de Sociologia do Instituto

Universitário de Lisboa (CIES/ISCTE)

Autor da trilogia Estados de Espírito e Poder

\section{CECI VILAR NORONHA}

Professora do Instituto de Saúde Coletiva/UFBA

Doutora em Saúde Pública pela Universidade Federal da Bahia (UFBA)

Pesquisadora do Laboratório de Estudos em Violência, Saúde e Sociedade (LAVISS)

Linha de Pesquisa: Violência Urbana e Saúde

Produção: Estudos Relativos à Vitimização contra Crianças e Adolescentes

\section{CLÁUDIA MORAES TRINDADE}

Professora do Centro Universitário Jorge Amado (UNIJORGE) e Professora Substituta da Universidade Federal da Bahia (UFBA) Doutoranda do Programa de Pós-Graduação em História da Universidade Federal da Bahia (UFBA) Integrante do grupo de pesquisa Escravidão e Invenção da Liberdade Autora de artigos e comunicações ligados ao sistema prisional. Atualmente desenvolve pesquisa sobre o cotidiano prisional na Bahia do século XIX. 


\section{CLÁUDIA REGINA VAZ TORRES}

Professora da Universidade Salvador, Fundação Visconde de Cairu e UNEB

Doutora em Educação pela Universidade Federal da Bahia (UFBA) Integrante do Grupo de Pesquisa Formação Docente, Memória e Educação

Autora de artigos ligados ao sistema prisional

Psicóloga da Secretaria da Justiça, Cidadania e Direitos Humanos do Estado da Bahia (SJCDH)

\section{DENISE CARRASCOSA}

Professora de Literaturas de Língua Inglesa do Instituto de Letras da Universidade Federal da Bahia (UFBA)

Doutora em Teorias e Crítica da Literatura e da Cultura pela UFBA Líder do Grupo de Pesquisa Popol Vuh - Grupo de Pesquisa de Narrativas Contemporâneas das Américas

Tese de doutorado sobre o tema Produções de subjetividades marginais e narrativa como política de si

\section{JOSÉ GONÇALO PAIS ESTRELA DA SILVEIRA ZÚQUETE}

Mestre em Saúde Comunitária pelo Instituto de Saúde Coletiva/ UFBA

Integrante do Laboratório de Estudos em Violência, Saúde e Sociedade (LAVISS)

Linha de Investigação: Violência Urbana e Saúde

\section{LUIZ CLAUDIO LOURENÇO}

Professor Adjunto do Departamento de Sociologia da Universidade Federal da Bahia (UFBA)

Doutor em Ciência Política (Ciência Política e Sociologia) pelo IUPERJ

Pesquisador do Grupo de Pesquisa LASSOS - Laboratório de Estudos em Segurança Pública, Cidadania e Solidariedade

Autor de artigo ligado ao sistema prisional

\section{MARIA THEREZA ÁVILA DANTAS COELHO}

Professora do Instituto de Humanidades, Artes e Ciências Professor 
Milton Santos da UFBA

Doutora em Saúde Pública pela Universidade Federal da Bahia (UFBA)

Coordenadora do - Núcleo de Estudos Interdisciplinares em Saúde, Violência e Subjetividade (SAVIS)

Pesquisadora e autora de artigos e comunicações ligados ao sistema prisional

Ex-psicóloga da Secretaria de Justiça, Cidadania e Direitos Humanos do Estado da Bahia

\section{MILENA PEREIRA PONDÉ}

Professora Adjunta da Escola Bahiana de Medicina e Saúde Pública (EBMSP)

Doutora em Saúde Pública pela Universidade Federal da Bahia (UFBA)

Pós-Doutora pela McGill University, Montreal, Canadá

Pesquisadora do Laboratório Interdisciplinar de Pesquisa em

Autismo

Autora de artigo ligado ao sistema prisional

Médica Psiquiatra

\section{MILENA SIQUEIRA SANTOS MENDONÇA}

Mestranda em Administração pela Universidade Federal da Bahia (UFBA)

Pesquisadora do LABMUNDO-UFBA e do Laboratório

Interdisciplinar de Pesquisa em Autismo (EBMSP)

Especialista em Direito do Estado pelo JusPodivm

Advogada

\section{MILTON JÚLIO DE CARVALHO FILHO}

Doutor em Ciências Sociais (Antropologia)

Professor Adjunto do Instituto de Humanidades, Artes e Ciências

Prof. Milton Santos, Universidade Federal da Bahia (UFBA)

Coordenador do Núcleo de Estudos Interdisciplinares em Saúde, Violência e Subjetividade (SAVIS)

Pesquisador e autor de artigos de comunicação relacionados ao

Sistema Prisional, Violências e Cidades 


\section{ODILZA LINES DE ALMEIDA}

Professora Assistente da Universidade Estadual do Sudoeste da Bahia

Doutoranda em Saúde Pública pela Universidade Federal da Bahia (UFBA)

Integrante do Grupo de Pesquisa Laboratório de Estudos em Segurança Pública, Cidadania e Solidariedade (LASSOS) Integrante do Grupo de Pesquisa Laboratório de Violência, Saúde e Sociedade (LAVISS)

Psicóloga da Secretaria de Justiça, Cidadania e Direitos Humanos do Estado da Bahia

Autora de dissertação, tese, artigos e comunicações ligados ao sistema prisional

\section{PAULO FURQUIM DE AZEVEDO}

Professor da Escola de Economia da Fundação Getúlio Vargas - SP Doutor em Economia pela Faculdade de Economia, Administração e Contabilidade (FEA) da Universidade de São Paulo (USP) Autor de diversas publicações ligadas ao sistema prisional

\section{SANDRO CABRAL}

Professor da Escola de Administração da Universidade Federal da Bahia (UFBA)

Doutor em Administração pela UFBA

Coordenador do Grupo de Pesquisa Estratégia e Desempenho em Serviços Públicos

Autor de diversas publicações ligadas ao sistema prisional 
Colofão

Formato $\quad 17 \times 24 \mathrm{~cm}$

Tipologia ZapfEllipt BT 11/15

Papel Alcalino $75 \mathrm{~g} / \mathrm{m}^{2}$ (miolo)

Cartão Supremo 300 g/m² (capa)

Impressão EDUFBA

Capa e Acabamento Cian Gráfica

Tiragem 400 exemplares 